\title{
JOINT HIGHWAY
}

RESEARCH PROJECT

FHWA/ISHC/JHRP-78/21

DEVELOPMENT OF A SYSTEM

FOR THE EVALUATION

OF PAVEMENTS IN INDIANA

\section{Satish Mohan}
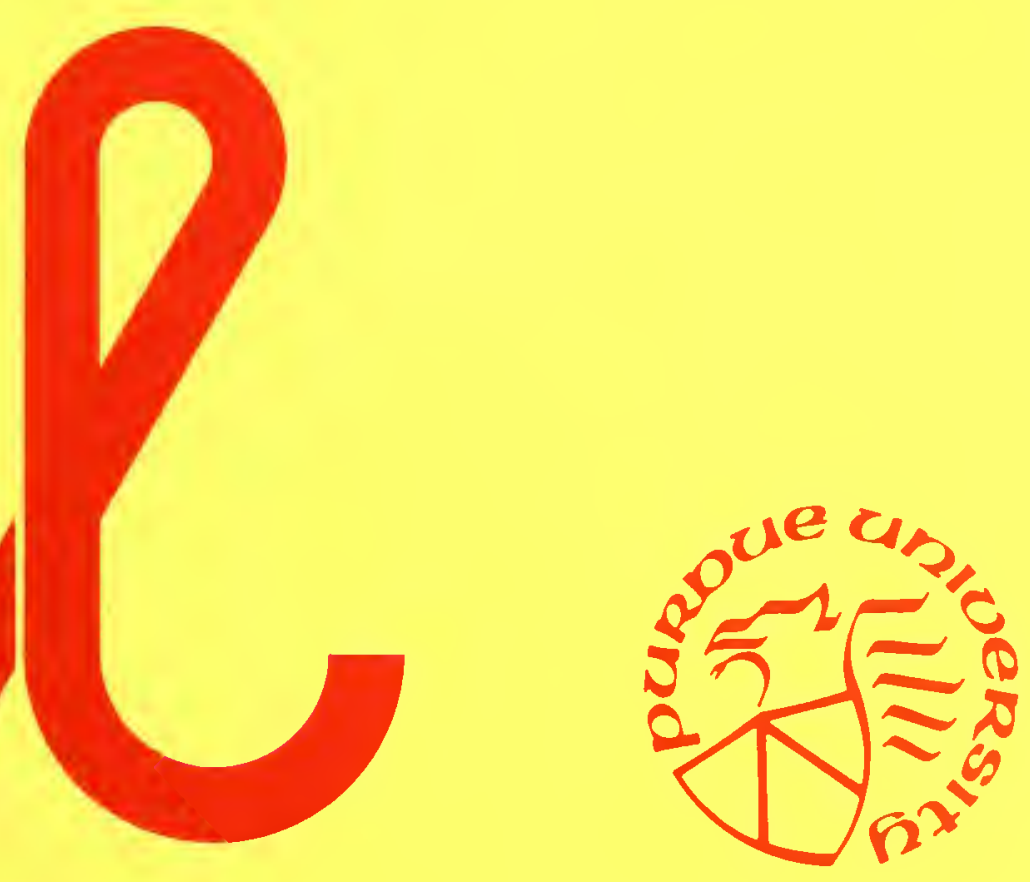

DEVELOPMENT OF A SYSTEM FOR THE EVALUATION OF PAVEMENTS IN INDIANA

TO: H. L. Michael, Director

Joint Highway Research Project

FROM: E. J. Yoder, Research Engineer

Joint Highway Research Project
October 3, 1978

File: $9-7-7$

Project: C-36-63G

The attached Interim Report is submitted on the JHRP Research Study entitled "Development of a System for the Evaluation of Pavements in Indiana". The report has been authored by Mr. Satish Mohan under the direction of Professor E. J. Yoder.

The research is a cooperative venture with the Indiana State Highway Commission Research and Training Center. Personnel from the Research and Training Center cooperated in laying out the research project and conducted most of the field work. They obtained all the data on road roughness using the Roadmeter, deflection using the Dynaflect and skid resistance.

This report summarizes data obtained from four types of pavement (1) flexible, (2) overlay, (3) jointed reinforced concrete and (4) continuously reinforced concrete. The research consisted of the following phases.
1. Roadmeter variability study
2. Selection of test sections
3. Pavement serviceability studies
4. Deflection studies
5. Skid studies

The report includes recommendations for calibrating the Roadmeter used by the Indiana State Highway Commission Research and Training Center and methods for making deflection measurements with the Dynaflect. Recommendations have been made for developing a pavement evaluation system using the mechanical methods noted above.

This report is issued as partial fulfillment of the objectives of the Study and will be submitted to ISHC and FHWA for review and similar acceptance.

Respectfully submitted,

EJY :ms

cc: A. G. Altschaeff 1

W. L. Dolch

R. L. Eskew

G. D. Gibson

W. H. Goetz

M. J. Gutzwiller

G. K. Ha1lock

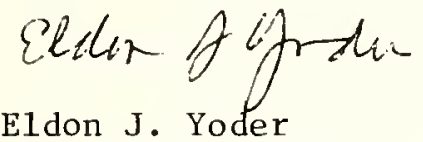

Research Engineer

D. E. Hancher

C. F. Scholer

K. R. Hoover

J. F. McLaughlin

M. B. Scott

K. C. Sinha

R. F. Marsh

R. D. Miles

P. L. Owens

G. T. Satter $1 y$
C. A. Venable

L. E. Wood

E. J. Yoder

S. R. Yoder 
Digitized by the Internet Archive in 2011 with funding from

LYRASIS members and Sloan Foundation; Indiana Department of Transportation 
Interim Report

DEVELOPMENT OF A SYSTEM FOR THE

EVALUATION OF PAVEMENTS

IN INDIANA

by

Satish Mohan

Graduate Instructor in Research

Joint Highway Research Pro,lect

Profect No.: $\quad$ C-36-63G

File No.: $\quad 9-7-7$

Prepared as Part of an Investigation

Conducted by

Joint Highwav Research Profect

Engineering Experiment Station

Purdue University

in cooperation with the

Indiana State Highway Commission

and the

U.S. . Department of Transportation

Federal Highway Administration

The contents of this report reflect the views of the author who is responsible for the facts and the accuracy of the data presented herein. The contents do not necessarily reflect the official views or policies of the Federal Highway Administration. This report does not constitute a standard, specification, or regulation.

Purdue University

West Lafayette, Indiana

October 3, 1978 
TECHNICAL REPORT STANDARD TITLE PAGE

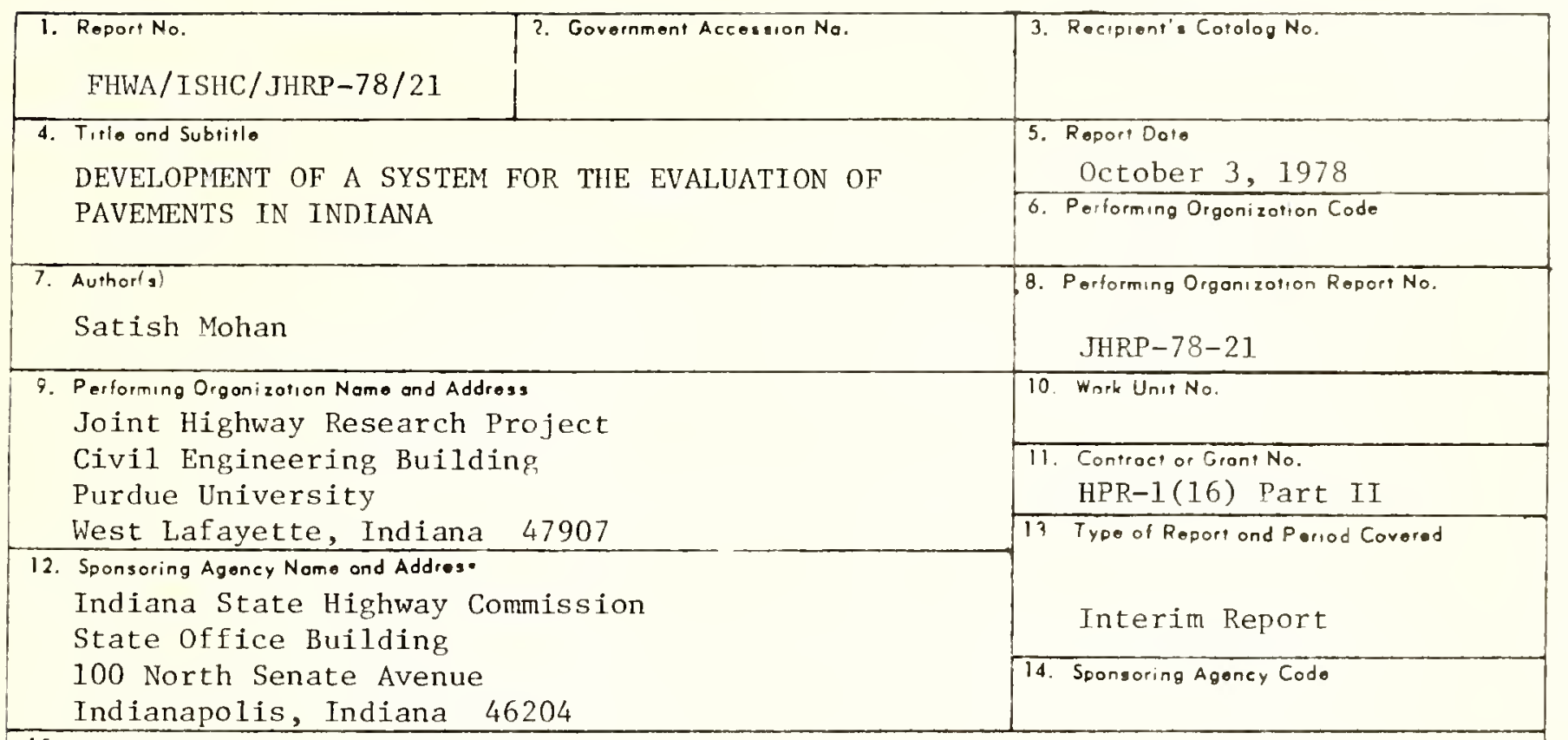

15. Supplomentory Notos

Prepared in cooperation with the U.S. Department of Transportation, Federal Highway Administration. From research study titled "Development of a System for the Evaluation of Pavements in Indiana".

16. Absiroct

The Indiana State Highway Commission uses subjective sufficiency ratings to determine highway needs. This research was initiated for the purpose of improving upon this and it had two specific objectives. (1) To set up a method of describing pavement performance in terms of measurements using the roadmeter, Dynaflect and skid tester and (2) To set up guidelines for a methodology for an on-going evaluation of pavement performance.

In-service pavements including flexible, overlay, jointed reinforced concrete and continuously reinforced concrete pavements were evaluated. Ninety-four test sections, each 1 kilometer long, were evaluated for the pavement serviceability studies. Forty-six test sections were selected for deflection and skid studies.

Present serviceability index (PSI) models were developed which relate PSR with roadmeter ratings alone, and with roadmeter measurements in combination with cracking, patching and other factors related to the pavement.

Deflection studies have indicated that edge deflections should be used for overlay design. Various models were developed which permit estimation of spring deflections using fall deflections.

Recommendations have been made for developing a pavement evaluation system. The system will work at two levels, (1) total network and (2) individual project level.

\section{Koy Words}

Present Serviceability Index, Present Serviceability Rating, Roadmeter, Deflection Measurements, Pavement Evaluation

\section{Diatribution Siotement}

No restrictions. This document is available to the public through the National Technical Information Service, Springfield, Virginia 22161.
19. Security Claseif. (af this report)

Unclassified
20. Securtiy Clasalf. (of thi poge)

Unclassified
22. Price 


\section{ACKNOWLEDGMENTS}

The author expresses his sincere appreciation to Professor Eldon J. Yoder, his major professor, for the guidance and critical review of the manuscript, and for his personal interest in various phases of this research.

Very special thanks and gratitude are due to Professor Harold $L$. Michael for his moral support and timely advice when needed. This research effort and academic pursuit could not have been fulfilled without his constant encouragement.

The author is thankful to members of his committee, Professor Virgil L. Anderson for his advice on data analysis and review of the manuscript; and Professor Robert D. Miles for his guidance in the area of geometric design and ready advice whenever needed.

Thanks are due to Professor Donald G. Shurig for providing soil maps.

Sincere thanks are extended to Mr. Barry E. Elkin, Assistant Director, Research and Training Center of the Indiana State Highway Commission for his constant cooperation and interest during the data collection phase, and review of the manuscript.

Thanks are due to Mr. Fred C. Chuck, Assistant Research Engineer, Research and Training Center of the Indiana State Highway Commission, for organizing field data collection. 
The help of Professor G. P. McCabe, Jr., and Mr. Thomas Kuczek on the statistical analysis during the absence of Professor V. L. Anderson is acknowledged.

The author is grateful to the Joint Highway Research Project of Purdue University who in cooperation with the Indiana State Highway Commission, Federal Highway Administration, U.S. Department of Transportation arranged financial support for this research.

The author is grateful to Purdue University for the financial assistance to pursue graduate studies.

Thanks are extended to Mrs. Cheryl Haines, Mrs. Sherry Miller, Mrs. Molly Harrington and Mrs. Marian Sipes for typing the manuscript.

Finally, very special appreciation and thanks are extended to the author's wife, Usha and children, Sumita, Vivek and Ankur who teamed up to sacrifice their due and cheerfully endured many hard times to see this goal accomplished. 
TABLE OF CONTENTS

Page

LIST OF TABLES .................................. vi

LIST OF FIGURES. . . . . . . . . . . . . . . . . $x_{i}^{*}$

DEFINITIONS OF TERMS .............................

HIGHLIGHT SUMMARY. . . . . . . . . . . . . . . xvi

CHAPTER 1: INTRODUCTION ................. 1

General Background. . . . . . . . . . . . 1

Objectives of this Research ............. 5

Organization. . . . . . . . . . . . . . 5

Scope of Study.................. . . 6

Pavement Performance Criteria . . . . . . . . . 7

CHAPTER 2: ROADMETER VARIABILITY STUDY. ......... 8

Purpose of the Study. . . . . . . . . . . . . 8

Selection of Influencing Factors. . . . . . . . . . . 8

Reducing the Number of Variables ............ 10

Selection of Test Sections.............. 11

Levels of Independent Variables . . . . . . . . . . 12

Air Temperature. . . . . . . . . . . . 12

Gas Tank Leve1................. . 14

Driver Type. . . . . . . . . . . . . . 15

Procedure ................. . . 15

Data Analysis ................... 16

Homogeneity of Variance Test . . . . . . . . . . 16

Transformation of Data............ 19

Test for Normality .............. . . 20

Development of Model .................. 21

Number of Roadmeter Passes. . . . . . . . . . . . . 29

Computations for the Number of RM Passes . . . . . . . . . 29

Considerations in the Choice of $\alpha$ and $\beta$ Errors . . . . . . . 31

Standard Conditions for Roadmeter Operation . . . . . . . . 36

Summary - Roadmeter Variability Study ... . . . . . . . . 37

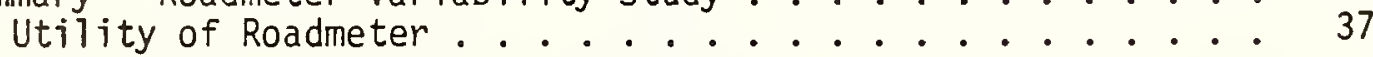

Adjustment of Roadmeter Measurements for the Effect of

Influencing Variables............. 37

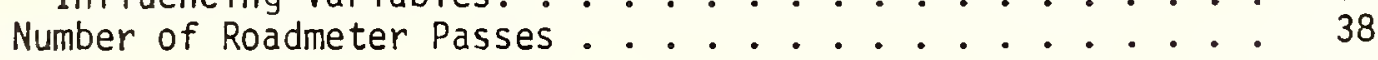


Page

CHAPTER 3: SELECTION OF TEST SECTIONS . . . . . . . . . . . . 40

Del ineation of Study Area . . . . . . . . . . . . . . 40

Coding of State Highway System. . . . . . . . . . . . . . . 40

Random Selection of the Test Sections . . . . . . . . . . 41

Pavement Data Collection. . . . . . . . . . . . . 44

Formation of Travel Loops . . . . . . . . . . . . . . . 47

Final Selection and Listing of Test Sections. . . . . . . . 48

CHAPTER 4: PAVEMENT SERVICEABILITY STUDIES. . . . . . . . . . . . . 49

Introduction. . . . . . . . . . . . . . . . . . 49 49

Present Serviceability Ratings. . . . . . . . . . . . 50

Selection of Rating Panel. . . . . . . . . . . . 50

Rating Procedure . . . . . . . . . . . . . . . . 51

Acceptability Levels of Various Pavement Types . . . . . . 53

Recommended Size of a Rating Team. . . . . . . . . . . 57

Measurement of Factors Affecting Pavement Serviceability. . . . 60

Measurement of Roughness Using Roadmeter . . . . . . . . 60

Measurement of Surface Properties. . . . . . . . . 60

Measurement of Extraneous Characteristics. . . . . . . . 64

Present Serviceability Index (PSI) Models . . . . . . . . 68

Development of Models. . . . . . . . . . . . . 69

Description of PSI Models. . . . . . . . . . . . . 74

Recommended Procedure to Determine Sufficiency Ratings from

PSI Values. . . . . . . . . . . . . . . . . . 76

Temporal Stability of the PSI Models. . . . . . . . . . . 77

Theoretical Analysis... . . . . . . . . . . 78

Recalibration Procedures . . . . . . . . . . . 79

CHAPTER 5: DEFLECTION STUDIES . . . . . . . . . . . . . . 81

Purpose of the Study. . . . . . . . . . . . . . . . 81

Study Plan....................... . . . . . 81

Selection of Test Sections . . . . . . . . . . . 81

Deflection Measurements. . . . . . . . . . . . . . . . 84

Selection of an Optimal Test Location Across the Width of

Pavement. . . . . . . . . . . . . . . . 86

Deflection Basin Parameters. . . . . . . . . . . 86

Selection Criteria... . . . . . . . . . . 87

Data Analysis. . . . . . . . . . . . . . . 88

Recommendations. . . . . . . . . . . . . . . 93

Number of Deflection Tests. . . . . . . . . . . . . 95

Relationship Between Spring and Fall Deflections. . . . . . . 96

Approach to the Development of Estimation Models . . . . 102 
Page

CHAPTER 6: SKID STUDIES .............. 106

Purpose .................. 106

Data Collection ................ 108

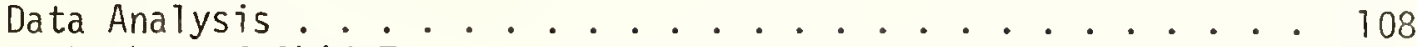

Number of Skid Tests.............. 108

Effects of Pavement Temperature and Vehicle Speed..... 109

Trends in Decay of Skid Resistance . . . . . . . . . . 113

Summary ................ 116

CHAPTER 7: RECOMMENDATIONS FOR DEVELOPING A PAVEMENT

EVALUATION SYSTEM. . . . . . . . . . . 117

General Framework .. . . . . . . . . . . . 117

Pavement Evaluation at the Total Network Level . . . . . 117

Pavement Evaluation at the Project Level . . . . . . . . 119

Procedure Outline . . . . . . . . . . . . . . 119

Inventory of Existing Pavements. . . . . . . . . . 120

Grouping Pavements into Homogenous Categories. . . . . . . 121

Establishing Control Sections. . . . . . . . . . . 121

Standard Conditions for Operating Pavement Evaluation

Equipment. . . . . . . . . . . . 122

Measurements of Pavement Performance Characteristics . . . 123

Plotting Pavement Performance Curves . . . . . . . . 123

Minimum Acceptable Levels. . . . . . . . . . . . . . . . . . 123

Optimal Routine Maintenance Methods. . . . . . . . . . 125

Overlay Design Procedures. . . . . . . . . . . 127

CHAPTER 8: SUMMARY AND CONCLUSIONS. . . . . . . . . . 128

LIST OF REFERENCES . . . . . . . . . . . . 132

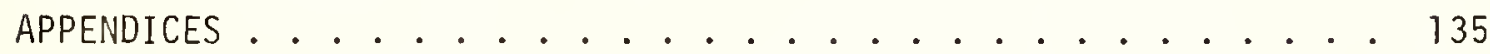

Appendix A: Abstracts from the Manual of Instructions for Determining State Highway Needs of the Indiana State Highway Commission ......... . 135

Appendix B: Roadmeter Variability Study. . . . . . . . . . 138

Appendix C: Selection of Test Sections . . . . . . . . . . 142

Appendix D: Pavement Serviceability Studies. . . . . . . . . 152

Appendix E: Deflection Studies .............. 167

Appendix F: Skid Studies ................ 173

VITA ........................... 175 


\section{LIST OF TABLES}

Table

1. Rural Roadway Subsection Rating ............. . 4

2. Properties of Test Sections used in the Roadmeter Variability Study . . . . . . . . . . . . . . 12

3. Roadmeter Variability Study Data. . . . . . . . . . . 17

4. Pavement Types. . . . . . . . . . . . . . 23

5. PSR Ranges for Determining Roughness Groups . . . . . . . . 23

6. Pavement Type-Roughness Groups. . . . . . . . . . . . 24

7. Revised Pavement Type-Roughness Groups. . . . . . . . . . 24

8. Pavement Type-Roughness Groups Having Equal Error of Roadmeter Measurements. . . . . . . . . . . . . 30

9. Number of Roadmeter Passes for Various Pavement TypeRoughness Groups. . . . . . . . . . . . . . . 32

10. Recommended Standard Values of the Influencing Factors. . . . 38

11. Breakdown of Routes of the Indiana State Highway Commission . 42

12. Coding of the State Highway System. . . . . . . . . . . . 43

13. Location Details of Random Numbers. . . . . . . . . . 45

14. Broad Properties of the 94 Test Sections. . . . . . . . . . . 48

15. Number of Raters Required to Estimate Present Serviceability Rating of Pavements............. . . . 59

16. Effect of Shoulder Width and Type on Effective Width of Pavements......................... 66

17. Determination of PSI Values from Roadmeter output . . . . . 71

18. Determination of Sufficiency Ratings from PSI Values. . . . 77 
Table

19. Mean Values of Deflection Parameters, Fall 1977 Data. . . . 91

20. Standard Deviations of Deflection Parameters, Fall 1977

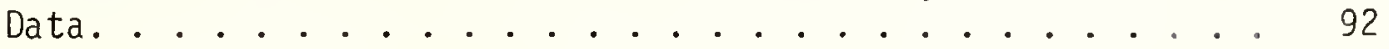

21. Comparison of 80th Percentile Variance at the Edge and Center. . . . . . . . . . . . . . . . . 94

22. Number of Deflection Tests Required per Test Section. . . . . 97

23. Models Relating Fall and Spring Deflection Parameters . . . 103

24. Number of Skid Tests Required per Test Section. . . . . . 110

25. Summary of Regression Analyses Results. . . . . . . . . . 112 Appendix A

Table

A1. Instructions to Assign Sufficiency Ratings. . . . . . . . . . 137 Appendix B Table

B1. Location Details of Test Sections . . . . . . . . . . 139

B2. Regression Coefficients for the Effect of Air Temperature . . 140

B3. Arrangement of Various Pavement Type-Roughness Groups into Five Groups Having Equal Error of Roadmeter Measurements. . .

Appendix C

Table

C1. Loop No. 1, Location References of Test Sections. . . . . . 142

C2. Loop No. 2, Location References of Test Sections. . . . . . 143

C3. Loop No. 3, Location References of Test Sections. . . . . . . 144

C4. Loop No. 4, Location References of Test Sections. . . . . . . 145

C5. Loop No. 5, Location References of Test Sections. . . . . . . 146 
Appendix D

Table

Page

01. Details of Raters.................... 152

02. Raters'Acceptability of Pavements.......... 153

D3. Pavement Data, Flexible Pavements . . . . . . . 155

D4. Pavement Data, Overlay Pavements - Cracks Measured with

Flexible Pavement Definition. . . . . . . . . . 158

05. Pavement Data, Overlay Pavements - Cracks Measured with

Rigid Pavement Definition............ 160

D6. Pavement Data, JRC Pavements. . . . . . . . . . 162

D7. Pavement Data, CRC Pavements. . . . . . . . . 163

D8. Properties of PSI Models, Flexible Pavements. . . . . . 164

D9. Properties of PSI Models, Overlay Pavements . . . . . . 165

D10. Properties of PSI Mode1s, JRC Pavements . . . . . . . 166

011. Properties of PSI Mode1s, CRC Pavements . . . . . . 166

Appendix E

Table

E1. Properties of 46 Test Sections............ 167

E2. Deflection Data, Flexible Pavements.......... 168

E3. Deflection Data, Overlay Pavements. . . . . . . . . 169

E4. Deflection Data, JRC Pavements. . . . . . . . . 170

E5. Deflection Data, CRC Pavements........... 171

E6. Summary of ANOVA. . . . . . . . . . . . . . . 172 Appendix F

Table

F1. Average Values of Skid Numbers of the 41 Test Sections. . . 173 


\section{LIST OF FIGURES}

Figure

1. Growth of State Highway Mileage in USA. . . . . . . . . 2

2. Growth of State Highway Mileage in Indiana. . . . . . . . 2

3. The PCA Roadmeter was Mounted in a Station Wagon. . . . . 9

4. Installation Arrangement of PCA Roadmeter . . . . . . . 9 9

5. Test Loop for Roadmeter Variability Study . . . . . . . . 13

6. Layout of Roadmeter Variability Experiment. . . . . . . 18

7. Effect of Air Temperature on Roadmeter Output for Various Pavement Type-Roughness Groups. . . . . . . . . . 26

8. Effect of Gas Tank Level on Roadmeter Output. . . . . . . . 27

9. Five Percent Random Sample of Miles in the Study Area . . . . 46

10. Title Page of a Rater's Book............. 52

11. Rating Card ... . . . . . . . . . . . 52

12. Social Acceptability Levels of Flexible Pavements on Two-Lane Facilities. . . . . . . . . . . . 54

13. Social Acceptability Levels of CRC Pavements on Multilane Facilities................ . . 54

14. Social Acceptability Levels of Overlay Pavements on Two-Lane Facilities............... . 55

15. Social Acceptability Levels of Overlay Pavements on Multilane Facilities. ............. 55

16. Social Acceptability Levels of JRC Pavements on Two-Lane Facilities................ 56

17. Social Acceptability Levels of JRC Pavements on Multilane Facilities. . . . . . . . . . . . . 
Figure

Page

18. Typical Layout of Test Sections ............. 62

19. Rut Depth Gage. . . . . . . . . . . . 63

20. Roadmeter Calibration, Flexible Pavements . . . . . . 72

21. Roadmeter Calibration, Overlay Pavements. . . . . . 72

22. Roadmeter Calibration, JRC Pavements. . . . . . . 73

23. Roadmeter Calibration, CRC Pavements. . . . . . . 73

24. The Indiana State Highway Commission's Dynaflect. . . . . 82

25. Dynaflect in the Operating Position . . . . . . . 82

26. Locations of 63 Deflection Tests.......... 85

27. A Typical Deflection Basin. ............ 85

28. Typical Yearly Fluctuations of DMD and SCI for Flexible

Pavements.......................... 101

29. The Indiana State Highway Commission's Skid Tester. . . . 107

30. Schematic of the Indiana State Highway Commission's Skid

Tester. ............... 107

31. Effect of Vehicle Speed on the Skid Resistance. . . . . . 114

32. Relationship between Fall 1977 and Spring 1978 Skid Numbers . 115

33. A Typical Pavement Performance Curve. . . . . . . . . 124

34. Comparison of Performances of Two Pavements Reaching

Terminal Serviceability Level at the Same Time. . . . . . 126

Appendix C

Figure

C1. Map of Travel Loop No. 1. ............. 147

C2. Map of Travel Loop No. 2. . . . . . . . . . . 148

C3. Map of Travel Loop No. 3. . . . . . . . . . . 149

C4. Map of Travel Loop No. 4. . . . . . . . . . . 150

C5. Map of Travel Loop No. 5. . . . . . . . . . 151 
DEFINITIONS OF TERMS

The following definitions have been used in this research. Wherever appropriate, symbols for the terms are given in parentheses.

Loop: A series of highways, 150 to 200 miles long beginning and terminating in Lafayette. These "Toops" constituted the test sections for the roadmeter studies.

Flexible Pavement: A pavement structure generally consisting of asphajtic concrete surfacing with a granular base and/or subbase (16)*.

Overlay Pavement: A pavement structure consisting of an asphaltic concrete surface over a jointed cement concrete pavement. The concrete may or may not contain reinforcement.

Jointed Reinforced Concrete Pavement (JRCP): A pavement structure consisting of portland cement concrete surfacing with or without subbase, with doweled transverse joints and reinforcement.

Continuously Reinforced Concrete Pavement (CRCP): A pavement structure consisting of portland cement concrete over a subbase, having no transverse contraction joints and containing high quantities of steel reinforcement.

Multilane Facility: A highway with four or more lanes, with or without a dividing median.

Test Section: A one kilometer long section of the outer lane. Each test section was uniform in its entire length with respect to pavement type, lane width, surface condition and traffic intensity.

Sub Section: A 400 meter long section of pavement randomly located within a test section.

Reference Lines: Lines marked at every 20 meters within a subsection.

Effective Width (W): A linear combination of outer 1 ane width and the width of shoulder weighted for the type of its surface according to the criteria specified in Table 16, Chapter 4.

* Numbers in parentheses refer to the references listed at the end of this report. 
Decision Roughness Level (DRL): That level of pavement roughness above which a pavement is considered a candidate for overlay from the point of view of roughness.

Effective Pavement Thickness ( $T$ ): A linear combination of the layers of a pavement after each layer has been multiplied by an equivalency factor (3) to convert it to asphaltic concrete thickness.

Present Serviceability Rating (PSR): The judgement of an observer as to the current ability of a pavement to serve the traffic it is meant to serve (16).

Present Serviceability Index (PSI): An estimate of average PSR, on a scale from 0-5 derived from regression equations.

n Percentile Acceptability Level of a Pavement: That value of PSR below which a pavement will not be acceptable to $n \%$ of the travelling public.

Rut Depth (RD): The maximum depth of rut in a wheel path of a pavement measured with a rut depth gage with a span of four feet.

Patching $(P)$ : Area of an asphait concrete patch, expressed in square feet of patching per 1,000 sq. ft. of surfacing (16).

Cracking (C) - Flexible Pavements: The amount of cracking in the pavement surface that exists, expressed in sq. $\mathrm{ft}$. of cracked area per $1000 \mathrm{sq}$. ft. of surface area (16). This cracking is further classified into three categories as in AASHO road test:

Class 1 cracking is the earliest type of cracking observed and consists of fine disconnected hairline cracks.

Class 2 cracking is common alligator cracking. This is cracking which has progressed to the stage where cracks have connected together to form a grid type pattern.

Class 3 cracking is that in which the bituminous surfacing segments have become loose.

Cracking (C) - Rigid Pavements: The amount of cracking, expressed in Tinear feet of projection per $1000 \mathrm{sq}$. ft. of surface area (16). This cracking is further classified into four categories as in AASHO road test:

Class 1 cracking includes fine cracks not visible under dry surface conditions to a man with good vision standing at a distance of $15 \mathrm{ft}$. 
Class 2 cracks are those that can be seen at a distance of $15 \mathrm{ft}$. but which exhibit only minor spalling such that the opening at the surface is less than 1/4 in.

Class 3 cracking is that which is opened or spalled at the surface to a width of 1/4 in. or more over a distance equal to at least one-half the crack length.

Class 4 crack is any crack which has been sealed. 


\section{HIGHL IGHT SUMMARY}

The availability of pavement evaluation equipment and large data handling facilities has made it possible to plan the maintenance of pavements at the state level. A systematic statewide procedure of pavement evaluation can result in the use of available maintenance funds to obtain maximum benefits. Many states have already set up their pavement evaluation systems which are now operational.

The Indiana State Highway Commission (ISHC) uses subjective numeric values called "sufficiency ratings", to determine needs and to fix improvement priorities on its pavements. This procedure does not ensure an expeditious and uniform assessment of the condition of pavements on the statewide basis. With this background, this research was initiated with two primary objectives:

1. To improve upon the existing procedure of ISHC by setting up a method of describing the performance of pavements in terms of objective measurements using the Roadmeter, Dynaflect and Skid Tester.

2. To set up guidelines for developing a methodology for an ongoing evaluation of pavement performance to fit Indiana conditions. 
Data from in-service pavements of the Indiana state highways was used to arrive at all the findings reported in this study. All the pavements were grouped into 4 categories, (1) Flexible, (2) Overlay, (3) Jointed reinforced concrete, and (4) Continuously reinforced concrete. The total research consisted of the following phases:

1. Roadmeter Variability Study

2. Selection of Test Sections

3. Pavement Serviceability Studies

4. Deflection Studies

5. Skid Studies

Roadmeter variability study found the effect of factors influencing the output of the roadmeter and formulated standard conditions for roadmeter operation.

A statistical procedure has been given for random sampling of pavement sections. For this research, a study area with a radius of 70 miles and having its center at West Lafayette was delineated. Ninetyfour test sections, representing a 11 possible combinations of influencing factors, were randomly selected within this study area for pavement serviceability studies. Each test section was one kilometer long. Out of these 94 test sections, 46 test sections were selected for deflection and skid studies. For deflection testing and for the measurement of rut depth, cracking and patching, a 400 meter long subsection was located in each test section.

In the pavement serviceability studies, a 11 the 94 test sections were independently rated by a team of 20 raters and the social acceptability levels of each pavement type have been determined. It 
was seen that 85 percent of raters desired a minimum present serviceability rating (PSR) of about 3.0 on multilane facilities and about 2.7 on two-lane facilities. Also, present serviceability index (PSI) models relating average PSR with the roadmeter measurements, cracking, patching and other factors related with the geometry and environment of the pavement, have been developed. Use of these models could replace the presently used procedure of the ISHC for describing the rideability of pavements.

Deflection studies have recommended the use of edge deflections for overlay design and have developed various models which can estimate spring deflections, which are critical for design, from the previous fall deflections.

It was seen in the skid studies that even minor variations in vehicle speeds have a significant effect on the skid measurements of jointed reinforced concrete and continuously reinforced concrete pavements.

Finally, recommendations have been made for developing a pavement evaluation system, using mechanical methods. The system will work at two levels, (1) Total network level and (2) Individual project level. The evaluation at the total network level will be used for planning purposes and for the identification of deficient pavement sections; while the one at individual project level will develop overlay designs. 


\section{CHAPTER 1: INTRODUCTION}

\section{General Background}

The growth of total state highway mileage in the USA is shown in Figure 1. The trend of the data is similar to that for Indiana where only 304 miles were added to the state highway system in the period from 1960-1975 as shown in Figure $2(41)^{*}$. As a result, much of the available resources for highways have been diverted to maintaining and upgrading the existing highway system.

For the general case, after a highway has been constructed, little can be done to change its geometry. However, there is a continuing need to upgrade and strengthen the pavement. In the context of highway maintenance, therefore, the pavement itself constitutes a very important component of the total maintenance program. This research effort is directed towards the pavement aspect of highway maintenance.

For pavement maintenance to be effective and optimal on the statewide basis, it is necessary to follow systematic and uniform procedures for evaluating the pavements and assessing their current and future needs. Evaluation procedures must be capable of supplying the necessary information quickly and uniformly and at the same time, be free from human biases and errors. On the basis of the results of the

*Numbers in parentheses refer to the references listed at the end of this report. 


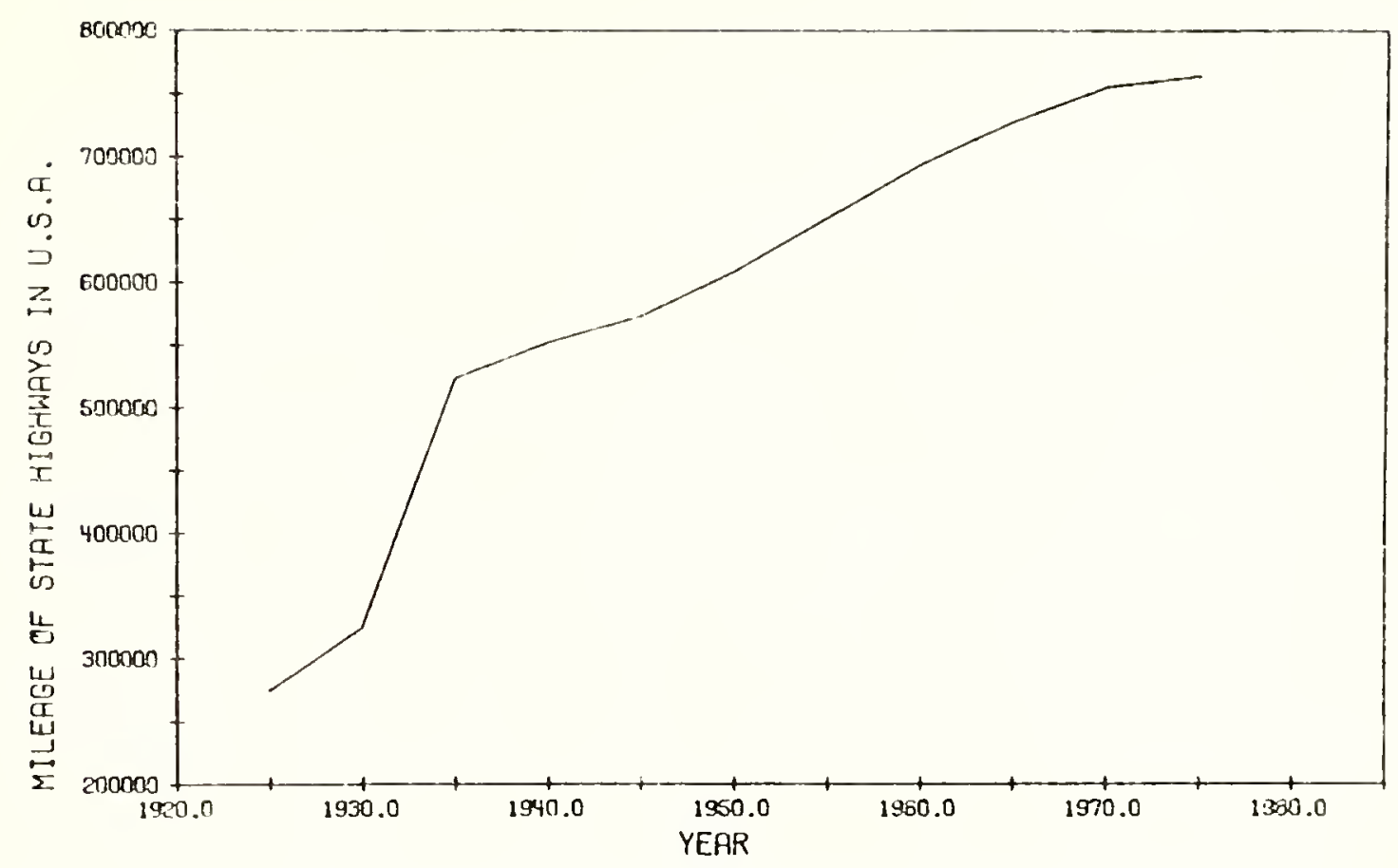

Figure 1: Growth of State Highway Mileage in USA

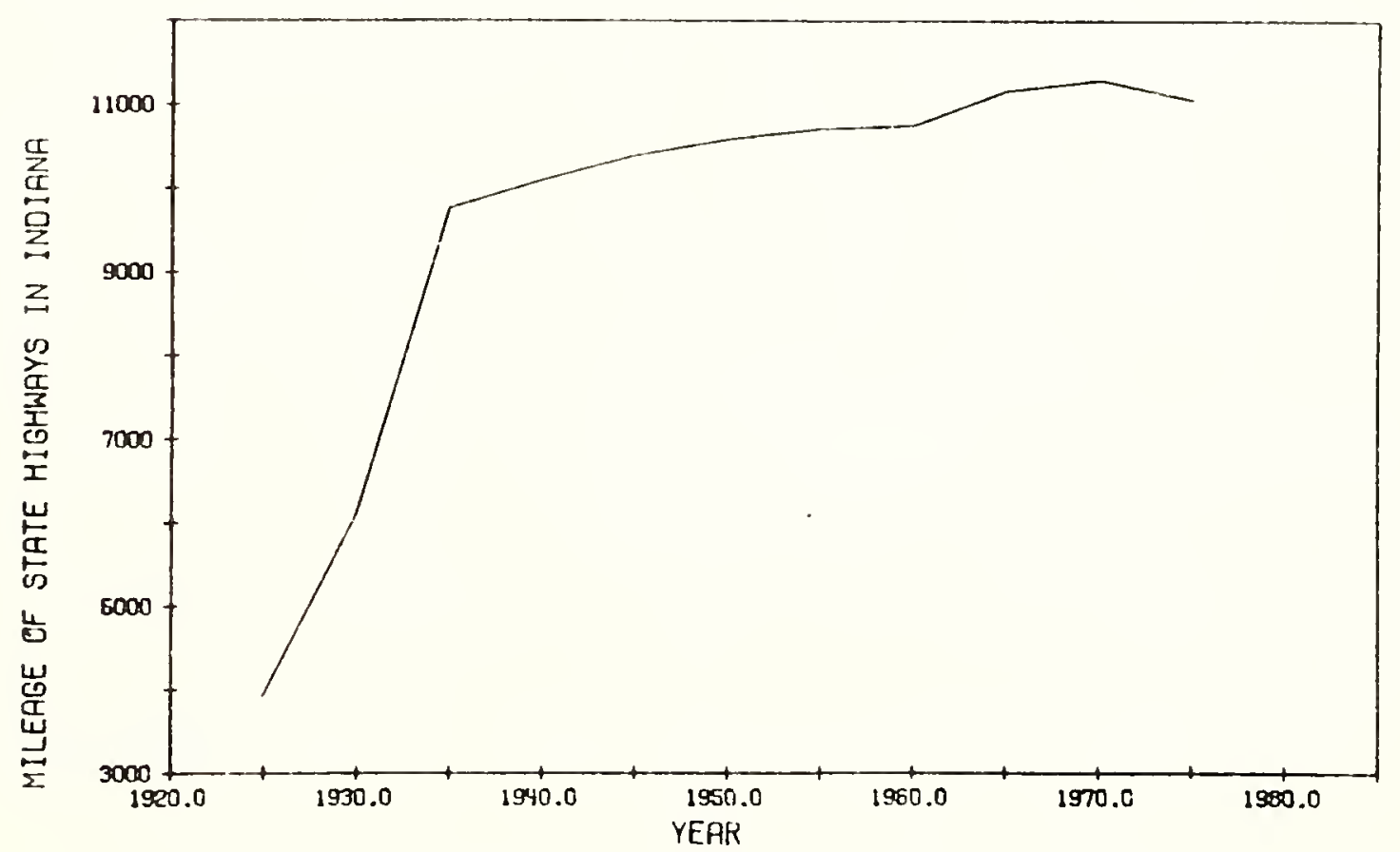

Figure 2: Growth of State Highway Mileage in Indiana 
AASHO Road Test (16), many states established procedures for studying the performance of pavements using objective measurements. For example, the engineers in the states of Utah (1), Texas (14), Washington (43), Minnesota (36), have established pavement evaluation procedures that are now operational.

The Indiana State Highway Commission follows the instructions and guidelines contained in a manual entitled "Manual of Instructions for Determining State Highway Needs" (27). This manual was prepared in 1964 as a part of ISHC's management improvement project in cooperation with Federal Highway Administration. The manual was later revised in November 1968 to keep pace with changes in standards and advancements in research, planning and programming.

According to this manual, the Indiana State Highway Commission uses subjective numeric values called 'sufficiency ratings', to determine needs and to fix improvement priorities on its highway system. Two teams, each consisting of two persons, accomplish this task in each of the six districts of the state. For rural roadway sections, the various elements used in calculating total sufficiency rating are given in Table 1. In this listing, the geometric features have a total maximum rating of 60 and the road condition elements are given a total maximum rating of 40 . Two elements of the latter group which are related with the pavement are:

1. Structural Adequacy

2. Rideability

Structural adequacy is assigned a maximum rating of 22 , and Rideability is assigned a maximum rating value of 5 . Guidelines for 
Table 1: Rural Roadway Subsection Rating*

Rural Roadway Subsection Rating

Rating Group

Geometrics

Condition
Related Element

Surface Type

Surface Width

Slroulder Type

Shoulder Width

Stopping Sight Distance

Alignment Consistency

Passing Opportunity

Total Geometrics Rating

Structural Adequacy

Drainage Adequacy

Rideability

Traffic Control

Total Condition Rating

Total Basic Sufficiency Rating
Maximum Rating Value

\section{5}

15

3

7

9

12

9

60

22

8

5

5

40

100

For evaluating rural roadway subsection improvement priorities, the basic sufficiency rating wiil be adjusted on the basis of the suosection's relative importance, traffic-wise. Adjustment factors have been developed from the equation below and are summarized by traffic volume groups in Appendix $H$.

$$
R_{a}=R_{b}+\frac{R_{b}\left(R_{b}-100\right)}{25 \log T_{s}}\left(\log T-\log T_{s}\right)
$$

Where

$R_{a}=$ Adjusted sufficiency rating

$R_{b}=$ Basic sufficiency rating

$T=$ Present day ADT on rated sub-section

$T_{s}=$ Present day ADT on rural state highway system

Note: Two different values of $T_{S}$ will be used; i.e., one for 4 or more lane rural highways and one for 2 of 3 lane rural highways.

For evaluating rural roadway subsection deficiencies ano determining improvement type, the basic sufficiency rating will be used without adjustment. 
determining structural condition and rideability are given in Appendix $A$ of this report, and instructions to assign sufficiency ratings to the various pavement conditions are given in Table Al of Appendix A.

\section{Objectives of this Research}

The procedure of the Indiana State Highway Commission which uses subjectively assigned numeric values (sufficiency ratings) for ascertaining pavement condition is time consuming in that raters must be used and it is subject to limitations of human judgement. The method does not ensure an expeditious and uniform assessment of the condition of pavements on the statewide basis. On the basis of the above, this research was initiated with two primary objectives in mind:

1. To improve upon the existing procedure by setting up a method of describing the performance of pavements in terms of objective measurements using the Roadmeter, Dynaflect and Skid Tester.

2. To set up guidelines for developing a methodology for an ongoing evaluation of pavement performance to fit Indiana conditions.

\section{Organization}

This research project was organized as a joint venture between Purdue University and the Research \& Training Center of the Indiana State Highway Commission. The design of the experiment, and analysis of data was done at Purdue University. The field data using the Roadmeter, the Dynaflect and the Skid Tester was collected by the research staff of the ISHC. 


\section{Scope of Study}

It was decided to delineate a study area with its center at Lafayette and having a radius of 70 miles. This allowed the various research teams stationed at Lafayette to travel to the site for data collection and return to Lafayette after the day's work. A total of 94 test sections each one kilometer in length, arranged in five travel loops and belonging to four pavement types (flexible, overlay, jointed reinforced concrete and continuously reinforced concrete) were selected for pavement serviceability studies. Only 46 of these 94 test sections were selected for deflection and skid studies. Of these 46 test sections, deflection data could be obtained for only 42 test sections during the fall of 1977 and 44 test sections during the spring of 1978 .

All the test sections used in this research were on the Indiana State Highway System and therefore all the results and findings of this research are applicable to the conditions prevailing in the state of Indiana. Only rural road sections were sampled in this study to avoid heavy traffic usually found on urban sections of state highways. All of the state highways were classified into two types of facilities:

(i) Two-lane facilities

(ii) Multilane facilities (those having four or more lanes). In the case of multilane facilities, all measurements were taken on the outer lane only.

A11 the test sections were grouped into 4 categories according to pavement type as below:

(i) Flexible pavements

(ii) Overlay pavements 
(iii) Jointed Reinforced Concrete (JRC) pavements

(iv) Continuously Reinforced Concrete (CRC) pavements.

\section{Pavement Performance Criteria}

Three main elements were considered in this study as major indicators of pavement performance:

(i) Serviceability - An estimate of the riding quality, as viewed by road users.

(ii) Structural Adequacy - The ability of pavement to support traffic loads without failure.

(iii) Skid Resistance - The slipperiness of the pavement surface. 
CHAPTER 2: ROADMETER VARIABILITY STUDY

\section{Purpose of the Study}

This phase of the research was conducted prior to the calibration of roadmeter possessed by the Indiana State Highway Commission (Figure 3) with the following objectives:

(1) To determine the various factors that influence the roadmeter output for the conditions prevailing in Indiana.

(2) To estimate the effect of the influencing factors on the roadmeter output at standard conditions so that the roadmeter measurements taken at other times can be adjusted to properly account for the effects of these influencing factors. These adjusted measurements will be a better estimate of pavement roughness and will be used in the calibration of the roadmeter.

(3) To determine the error of the roadmeter and using this error to establish the number of passes necessary to estimate roughness within an acceptable error.

\section{Selection of Influencing Factors}

Various studies $(23,40)$ done in the area of pavement evaluation using roadmeters have indicated that the following factors influence output:

1. Test Speed

2. State of Suspension System 


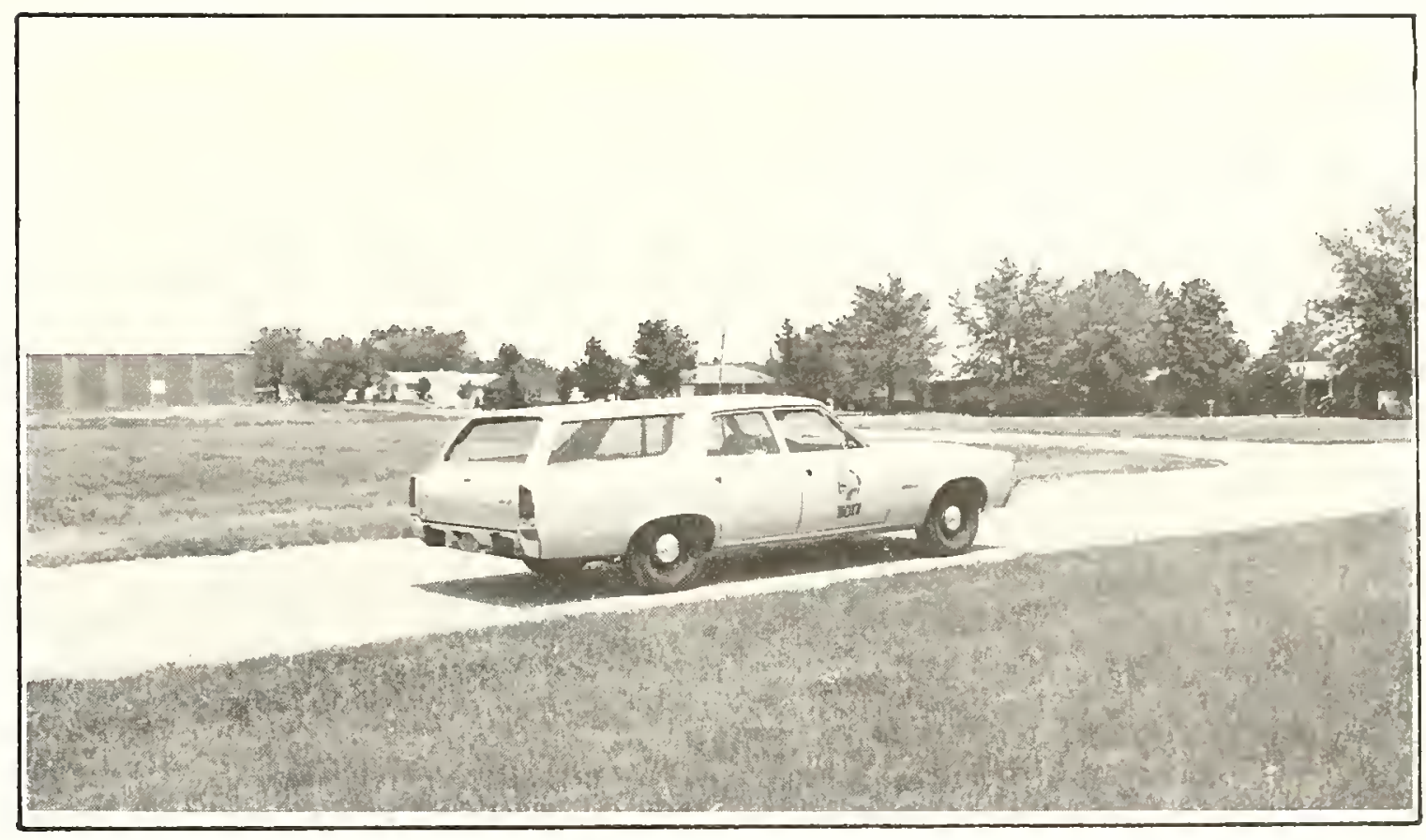

Figure 3: The PCA Roadmeter was Mounted in a Station Wagon

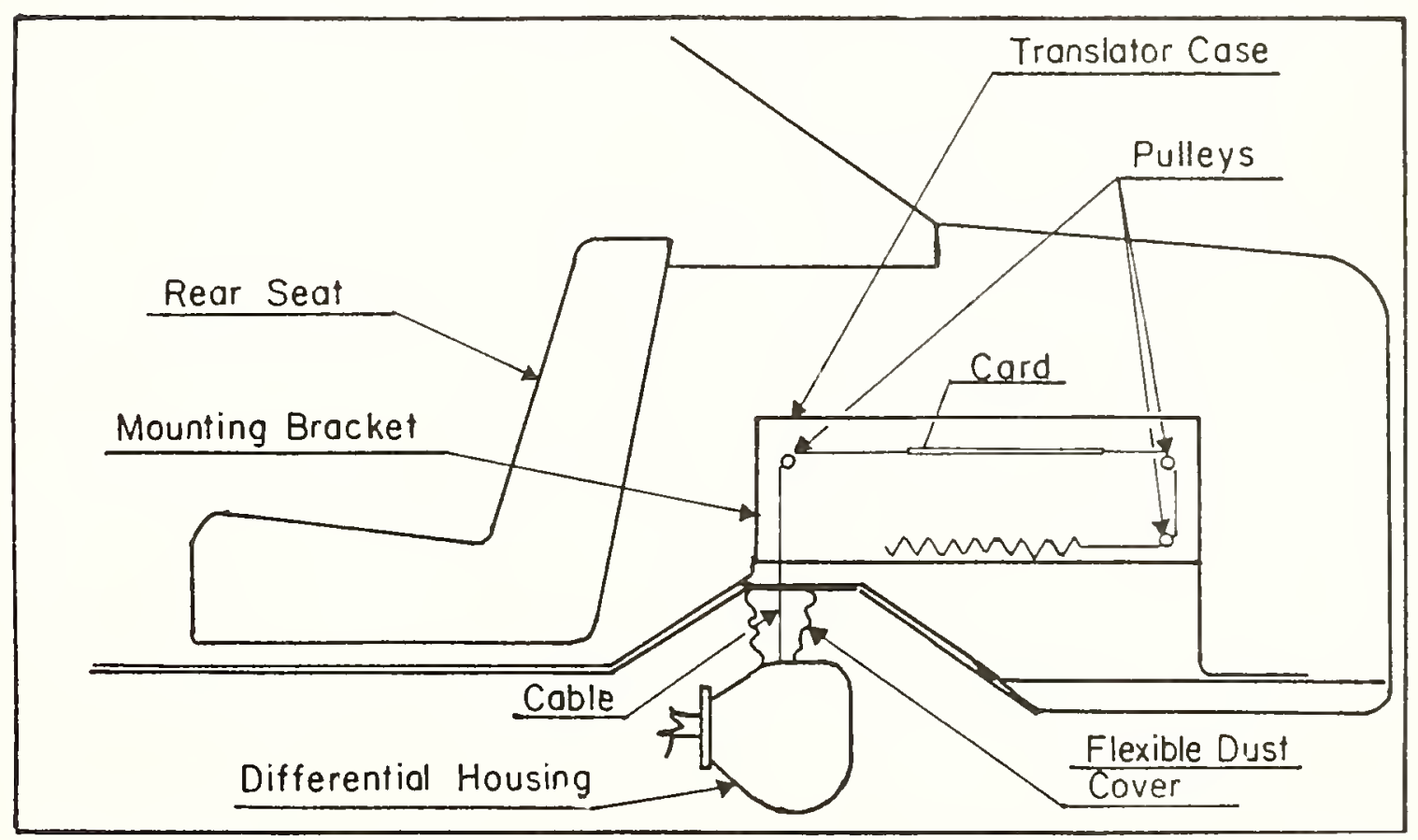

Figure 4: Installation Arrangement of PCA Roadmeter (After "Roadmeter Specifications" of James Cox \& Sons, Colfax, California) 
3. Tire Type and Size

4. Tire Pressure

5. Air Temperature

6. Gas Tank Lever

7. Crew Size

8. Wind Velocity

9. Driver Type.

The last factor was included in this study on the bas is of observations of the research engineers of the Indiana State Highway Commis sion who noticed that roadmeter measurements of the same test sections were always higher when the vehicle was driven by a particular individual.

\section{Reducing the Number of Variables}

The following variables were eliminated from the analysis as their significance is already known (23), and they do not effect the ISHC roadmeter any differently. Standard values of these variables are specified in Appendix B, entitled "Standard Conditions for Roadmeter Operation." These standard values were used in the variability study.

1. Test Speed

2. Tire Type and Size

3. Tire Pressure

4. Crew Size.

The factor'state of suspension system' is a function of (1) air temperature, and (2) changes in shock absorbers with usage. Since the air temperature is a factor by itself and changes in shock absorbers could not be appreciable during the short period of this study, this factor was eliminated. 
The wind velocity recorded during the roadmeter variability study was low, ranging from $0 \mathrm{mph}$ to $10 \mathrm{mph}$. This was a very narrow range for the determination of the effect of wind velocity on output; therefore, the factor 'wind velocity' was also dropped from this study.

The following three remaining factors were examined in this study:

1. Air Temperature

2. Gas Tank Leve1

3. Driver Type.

\section{Selection of Test Sections}

The selection of test sections was accomplished in accordance with the following guidelines:

1. Each test section was to be 1 kilometer long and this test length should be of only one pavement type and uniform roughness.

2. The selected test sections should fall in a convenient travel 10op for efficiency in measurements.

3. The loop should include an adequate number of test sections of each of the four pavement types and each pavement type should have test sections with a range of roughness.

4. All test sections should be within a 50 mile radius from the Research \& Training Center of the Indiana State Highway Commission located in West Lafayette, so that the study could be closely watched and controlled.

5. The test loop should touch at least two gas depots operated by the Indiana State Highway Commission for convenient and necessary adjustments of gas tank levels, even at odd hours. 
A preliminary inspection was made of most of the roads within 50 miles of West Lafayette. Based on this brief visual examination, the pavement type and initial PSR (on 0 to 5 scale) of the road sections were recorded. The relevant information pertaining to these road sections was stratified as to pavement type and roughness and plotted on a map. After applying the guidelines for test site selection, a loop ABCDEF, shown in Figure 5, was established. This loop was about 90 miles long, with two Indiana State Highway Commission depots located approximately at the $1 / 3$ points, and included 25 test-sections of the pavement type-roughness combinations, shown in Table 2. The roughness groups of Table 2, have been defined in Table 5 .

Table 2: Properties of Test Sections used in the Roadmeter Variability Study

\begin{tabular}{lccccc}
\hline TYPE OF & NUMBER OF & \multicolumn{3}{c}{ ROUGHNESS GROUP } \\
PAUEMENT & TEST & SECTIONS & SMOOTH & AUERAGE & ROUGH \\
\hline FLEXIBLE & 9 & 4 & 1 & 4 \\
OUERLAY & 6 & 1 & 4 & 1 \\
JRC & 4 & 0 & 2 & 2 \\
CP.C & 6 & 5 & 1 & 0 \\
\hline
\end{tabular}

As is evident from Table 2, rough CRC pavements were not available and smooth JRC pavements could not be included without a compromise on some more important benefits available in the selected loop. Location details of the 25 test-sections are given in Table BI of Appendix B.

\section{Levels of Independent Variables}

\section{Air Temperature}

To get the maximum temperature range, the roadmeter runs were scheduled during the coldest and hottest hours of the day which 


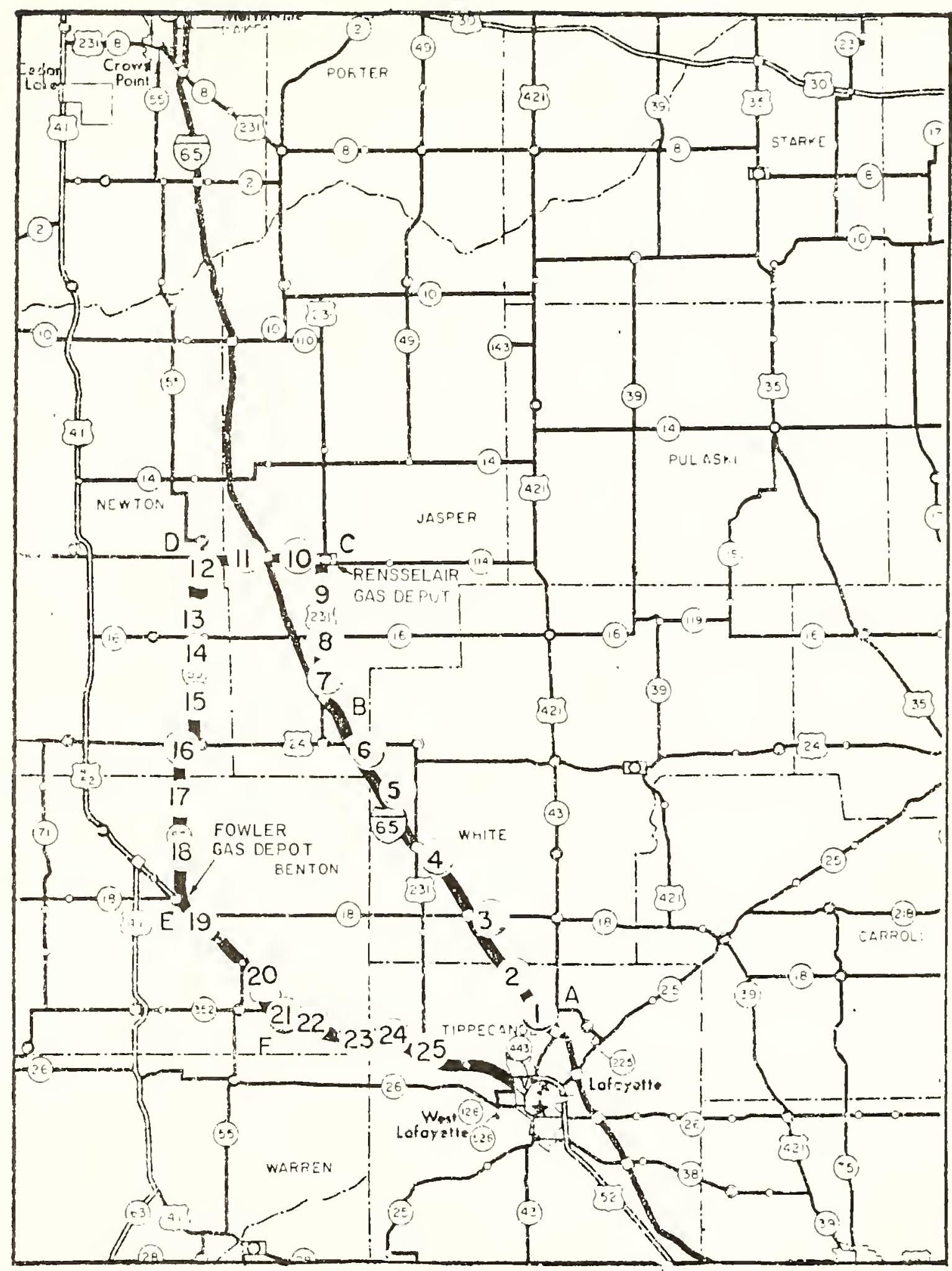

Figure 5: Test Loop for Roadmeter Variability Study 
normally occur at 4:00 a.m. and 2:00 p.m., respectively. During the first set of 10 runs over the test loop of 25 test sections, made on September 21, 22 and 23 of 1977, the air temperatures ranged from $41^{\circ} \mathrm{F}$ to $78^{\circ} \mathrm{F}$. In an effort to expand the applicability of this study, two more runs were made on January 11, 1978, at lower temperatures. Air temperatures for the 12 runs ranged from $15^{\circ} \mathrm{F}$ to $78^{\circ} \mathrm{F}$. A range of $15^{\circ} \mathrm{F}$ to $100^{\circ} \mathrm{F}$ would have been a more desirable range but the timing of this study did not allow waiting for higher temperatures.

Air temperatures were recorded every hour at the Research and Training Center. The temperature for each test-section was interpolated from the end-of-the-hour readings and these values were used in the analysis.

For ANOVA, two temperature levels were fixed as below:

$$
\begin{array}{ll}
\text { Air Temp. } \leq 60^{\circ} \mathrm{F} & \text { Level } 1 \\
\text { Air Temp. }>60^{\circ} \mathrm{F} & \text { Level } 2
\end{array}
$$

Gas Tank Leve1

The fuel gage of the roadmeter possessed by the Indiana State Highway Commission is divided in $1 / 8$ increments. Fuel levels were recorded at the three ISHC gas depots located at Lafayette, Rensselaer and Fowler. The value of the gas tank reading for each test section was computed from these recorded values. These computed values were used in the analysis.

For ANOVA, two levels of this factor were fixed as below:

$$
\begin{array}{rlrl}
0 & <\text { Gas tank level } & \leq 1 / 2 \text { Ful } 1 & \text { Level } 1 \\
1 / 2 \text { Ful } 1 & <\text { Gas tank level } \leq \text { Fur1 } & \text { Level } 2
\end{array}
$$


Driver Type

Steadiness in driving or speed fluctuations and tendency of a driver to maintain a certain distance from the outer-edge of the pavement are perhaps two driver-dependent attributes which could influence the roadmeter output. It was considered that these two attributes are functions of the age of the driver, the older driver being more steady and cautious.

Auto insurance companies, perhaps on the basis of accident records, have higher premiums for those under 25 years of age. The two levels of this factor were thus fixed as follows:

$$
\begin{array}{ll}
\text { Age } \leq 25 \text { years } & \text { Level } 1 \\
\text { Age }>25 \text { years } & \text { Level } 2
\end{array}
$$

In the regression analysis, this factor was used as a dummy variable. Two drivers were picked from the staff of the Research and Training Center of the Indiana State Highway Commission so as to satisfy both levels of this factor.

\section{Procedure}

Both the ends of the 25 test-sections were marked with white paint so they would be visible at a long distance and the starting end of each section was marked with flagging. Each test-section was one kilometer in length.

Twelve passes of the roadmeter were made on loop ABCDEF (Figure 5) covering the 25 test-sections, in four days. The various treatment combinations were randomly picked to reduce errors due to those extraneous influences not included in the experiment and efforts were made to cover all possible treatment-combinations to ensure at least one 
observation per cel1. Layout of the experiment indicating number of observations obtained in each cell is shown in Figure 6 . Since each test-section was unique, the 25 test-sections were treated as 25 levels of a factor 'Test-Sections' for analysis.

The roadmeter output of 12 runs is given in Table 3 , in terms of roadmeter counts per kilometer $(\Sigma \mathrm{C} / \mathrm{km})$.

\section{Data Analysis}

Homogeneity of Variance Test

On arranging the data in the respective cells it was seen that out of a total of 200 cells, 16 cells were empty, 94 cells had 1 observation, 65 had 2 observations and 25 cells had 3 observations. As a first step in the analysis of data, variances of 90 cells which had more than 1 observation per cell were tested for homogeneity. Bartlett's Test and the Foster-Burr Test on data, rejected the hypothesis of Homogeneity of Variance at 0.001 significance level (2). The various statistics from computer outputs are given below:

(i) Bartlett's Test:

DF $\frac{\text { Chi Square }}{89}$

Critical values of $x^{2}$

$\chi^{2} .05(89)=112.01$

$x^{2} .01(89)=122.94$

$x^{2} .001(89)=135.97$

Since $x^{2}$ calculated $>x^{2}$ critical

$\therefore$ Reject Homogeneity of Variance 


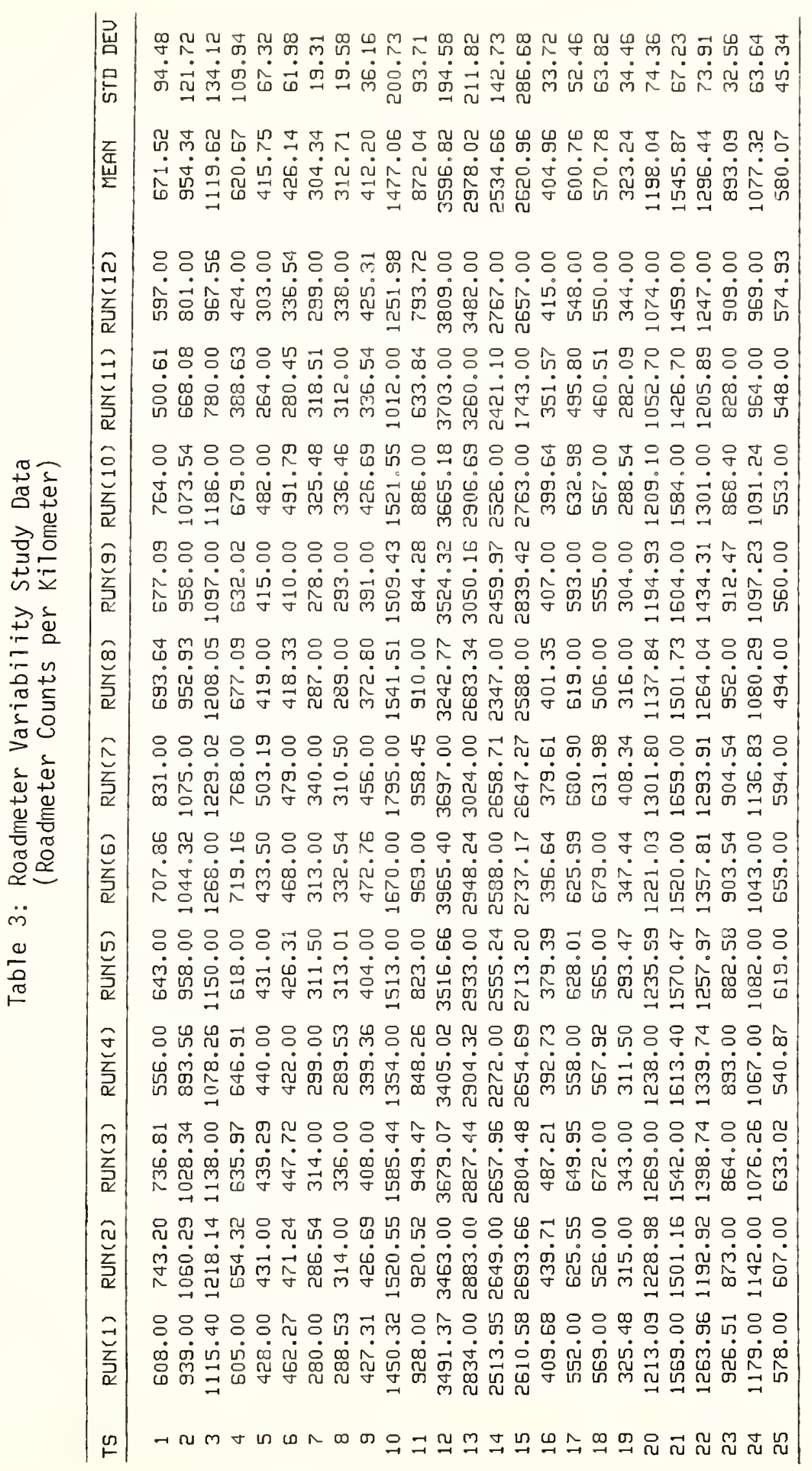




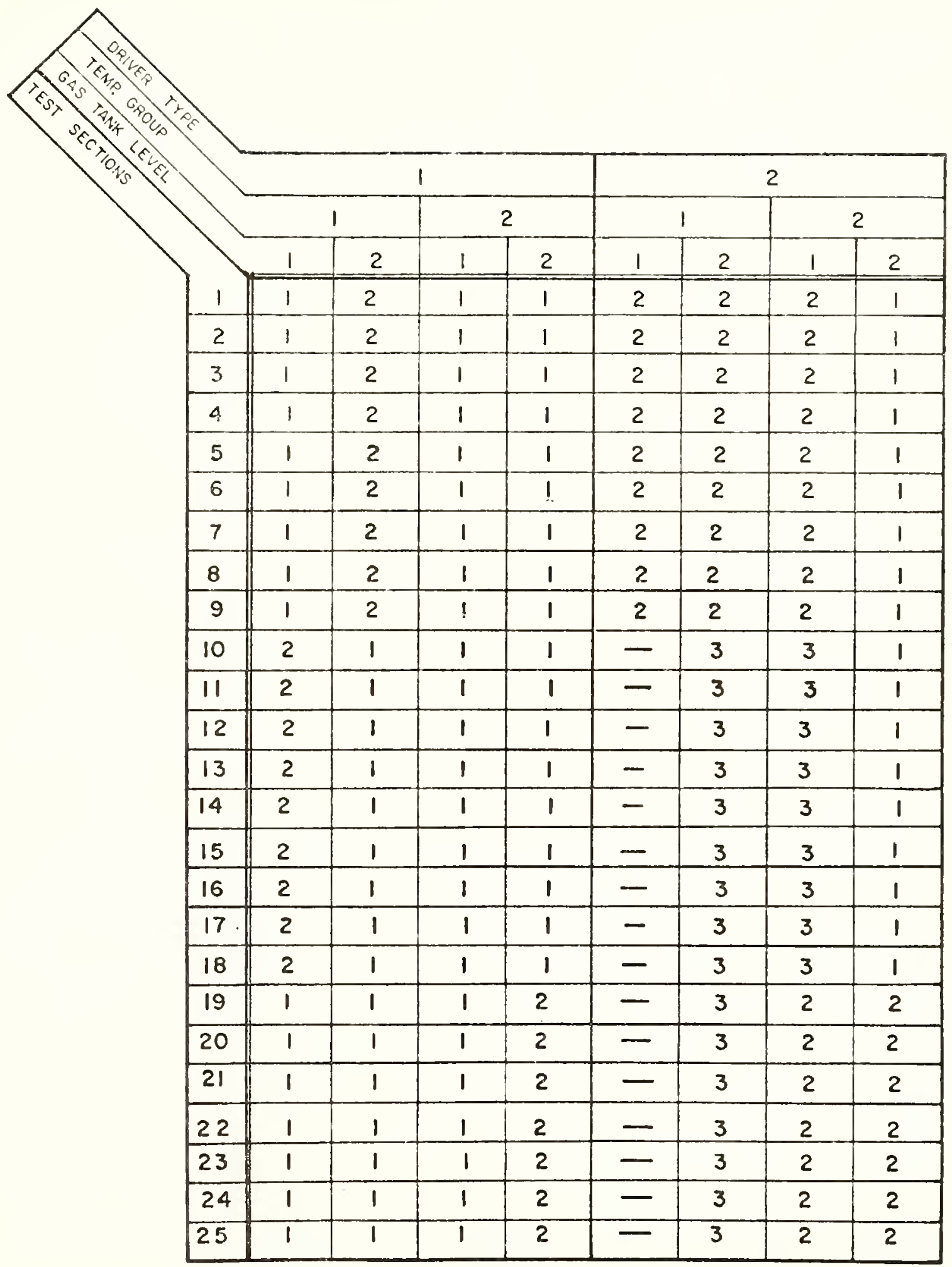

Numbers in cells show the frequency of observations in that cell.

Figure 6: Layout of Roadmeter Variability Experiment 
(ii) Foster-Burr Test:

\begin{tabular}{|c|c|c|c|}
\hline $\begin{array}{l}\text { Average DF } \\
\text { per Sample }\end{array}$ & $\begin{array}{c}\text { Degrees of } \\
\text { Freedom }\end{array}$ & $\begin{array}{l}\text { No. of } \\
\text { Samples }\end{array}$ & Q Statistic \\
\hline 1 & 1 & 90 & .1060 \\
\hline \multicolumn{4}{|c|}{ Critical values of 0 statistic } \\
\hline$Q(.05, \gamma=1, p=90)$ & $=.0613$ & & \\
\hline$Q(.01) \gamma=1, p=90)$ & $=.0731$ & & \\
\hline $0(.001, \gamma=1, p=90)$ & )$=.0940$ & & \\
\hline
\end{tabular}

\section{Transformation of Data}

Since homogeneity of variance was rejected at all significance levels, a transformation of data was attempted to make the variances homogenous. To achieve the best transformation, the following relations between the statistics of each cell having 2 and 3 observations were plotted and examined:

\section{Plot}

Correlation

(i) Cell Means $(\bar{X}) \mathrm{v} / \mathrm{s}$ Cell Std. Deviations (S) .90695

(ii) Cell Means $(\bar{X})$ v/s Cell Variances $\left(s^{2}\right)$ .81517

(iii) Cell Mean Squares $\left(\bar{X}^{2}\right) v / s$ Cell Std. Deviations (S) $\quad .78216$

The above correlations indicated that the mean was best correlated with standard deviation and hence a logarithmic transformation was the most logical (7). However, the following transformations were examined on data:

1. $Y^{\prime}=\log _{10} Y$

2. $\gamma^{\prime}=\sqrt{\gamma}$

3. $Y^{\prime}=\sqrt{\gamma}+\sqrt{1+Y}$ 
Homogeneity of variance tests on the transformed data gave the following statistics:

(i) Bartlett's Test

$$
\begin{aligned}
& \text { Transformation Chi square } x^{2} \text { Critical (.001) } \\
& \begin{array}{lll}
\text { None } & 191.1028 & 135.97
\end{array} \\
& \log _{10} Y \quad 144.3879 * \\
& \sqrt{Y} \quad 144.4423 \\
& \sqrt{\gamma}+\sqrt{1+\gamma}
\end{aligned}
$$

(ii) Foster-Burr Test

$$
\begin{array}{lcc}
\text { Transformation } & \frac{0 \text { Statistic }}{\text { None }} & \text { 0 Critical (.001) } \\
\log _{10} Y & .1060 & .0940 \\
\sqrt{Y} & .0554^{\star} & \\
\sqrt{Y}+\sqrt{1+Y} & .0620 &
\end{array}
$$

Both the tests showed that $\log _{10} \gamma$ transformation was the best.

$$
\text { Test for Normality }
$$

The Shapiro-Wilk Test for normality was seen on the original data of 25 cells having 3 observations and data was found to be normal in 24 cells at $\alpha=.01$ and in one cell at $\alpha=.001$. Since transformation of data generally improves normality property of data, any normality test on transformed data was not considered necessary. 


\section{Development of Mode 1}

The initial model with all factors and interactions is given below:

$$
\begin{aligned}
Y_{i j k \ell m}=\mu & +S_{i}+G_{j}+T_{k}+D_{\ell}+S G_{i j}+S T_{i k} \\
& +S D_{i \ell}+G T_{j k}+G D_{j \ell}+T D_{k \ell} \\
& +S G T_{i j k}+S G D_{i j \ell}+G T D_{j k \ell}+S T D_{i k \ell} \\
& +S G T D_{i j k \ell}+\varepsilon_{(i j k \ell) m}
\end{aligned}
$$

where: $Y=\log _{10}$ (RM counts) - TRMCONTS

$$
\begin{aligned}
S= & \text { Effect of the } i \text {-th level of Test Sections, } \\
& i=1,2, \ldots, 25-\text { TSECT } \\
G= & \text { Effect of the } j \text {-th level of Gas Tank Leve1, } \\
& j=1,2 \text { - GASLVL } \\
T= & \text { Effect of the } k \text {-th level of Air Temperature } \\
& k=1,2 \text { - TMPGRUP } \\
D= & \text { Effect of the } \ell \text {-th level of Driver Type } \\
& \ell=1,2 \text { - DRIVTYP }
\end{aligned}
$$

Interaction terms and error have their usual meaning.

Three and four factor interactions had no understandable interpretation in this study and therefore, ANOVA with only 2 factor interactions was done. ANOVA revealed the following:

1. Effect $G_{j}$ (GASLVL) is not significant.

2. 2 factor interactions $\mathrm{SD}_{i \ell}($ TSECT $\times$ DRIVTYP), $T D_{k \ell}\left(\right.$ TMPGRUP $\times$ DRIVTYP) and $D G_{j \ell}(D R I V T Y P \times G A S L V L)$ are significant.

3. Of the two factors, found to be significant TMPGRUP explains much more variation than DRIVTYP. 
Since we will be finding out the effect of each significant factor separately for each of the 25 Test Sections, interaction SD $_{i \ell}$ was not important. Interaction $\mathrm{TD}_{k \ell}$ had no intuitive appeal and $\mathrm{DG}_{j \ell}$ was not explainable, more so when GASLVL was insignificant. The Model was thus reduced to the following form for Regression Analysis:

$$
Y_{i j k \ell m}=\mu+S_{i}+G_{j}+T_{k}+D_{\ell}+\varepsilon_{(i j k \ell) m}
$$

Regression Analysis. The regression form of the ANOVA model will be:

$$
\begin{aligned}
\log _{10} Y= & B_{0}+B_{1 i}\left(\text { TSECT }_{i}\right)+B_{2}(\text { GASLVL }) \\
& +B_{3}(\text { TEMPERATURE })+B_{4 \ell}\left(\text { DRIVTYP }_{\ell}\right)
\end{aligned}
$$

where: $Y=R M$ counts in $\Sigma C /$ kilometer

$$
\begin{aligned}
B_{0}= & \text { Mean counts in } \Sigma C / k i l o m e t e r \\
B_{1 i}= & \text { Regression Coefficient for Test Section } i \\
& \text { where } i=1,2, \ldots 25 \\
B_{2}= & \begin{array}{l}
\text { Regression Coefficient for Gas Tank Level } \\
\text { which varies from } 0 \text { to } 1
\end{array} \\
B_{3}= & \text { Regression Coefficient for Temperature }\left(i n{ }^{\circ} \mathrm{F}\right) \\
B_{4 l}= & \text { Regression Coefficient for Driver type, } \ell=1,2
\end{aligned}
$$

The Regression Analysis was performed using standard computer programs available from the Purdue University Computing Center. Initial analysis showed that after the effect due to test sections was accounted for, a 11 the three factors, Gas Tank Level, Air Temperature and Driver Type, significantly influenced the RM measurements. Air Temperature was most important while the Gas Tank Level was least important.

For the statewide applicability of the results of this study, the 25 test sections were grouped into 12 pavement type - roughness groups 
(PR groups): so that any other road section in the state could be related to one of the 12 categories. Three roughness classes were formed on the basis of subjective ratings of these test sections on 0-5 scale by a member of the research team, as in Table 5.

The 12 pavement type-roughness groups are defined in Table 6. JRC smooth and CRC rough pavements were not available in this study, and therefore data was analysed for the effect of the three factors on 10 pavement type-roughness groups only.

Table 4: Pavement Types

\begin{tabular}{cc}
\hline PAUEMENT TYPE & CODE \\
\hline FLEXIBLE & 1 \\
OUERLAY & 2 \\
JRC & 3 \\
CRC & 4 \\
\hline
\end{tabular}

Table 5: PSR Ranges for Determining Roughness Groups

PSR RANGE ROUGHNESS GROUP CODE

\begin{tabular}{|c|c|c|c|}
\hline \\
\hline $3.5<$ & PSR & SMOOTH & 1 \\
\hline $2.0 \mathrm{~s}$ & $\begin{array}{l}\text { PSR } \leq 3.5 \\
\text { PSR }<2.0\end{array}$ & $\begin{array}{l}\text { AUERAGE } \\
\text { POUH }\end{array}$ & 5 \\
\hline
\end{tabular}

Effect of Air Temperature. The effect of air temperature was found to be significant for PR groups 2, 3, 6, 7, 9, 10. Since the confidence intervals of a few adjacent PR groups overlapped, the 10 PR groups were further merged into 5 groups as given in Table 7 . 
Table 6: Pavement Type - Roughness Groups

\begin{tabular}{|c|c|c|c|c|}
\hline PRUEMENT TYPE & E-ROUGHNESS & CODE COMBINATION & PR GROUP & TEST SECTIONS \\
\hline FLEXIBLE & - SMOOTH & 11 & 3 & $11,16,17,18$ \\
\hline FLEXIBLE & - AUERAGE & 12 & 2 & 10 \\
\hline FLEXIBLE & - ROUGH & 13 & 1 & $12,13,14,15$ \\
\hline DUERLRY & - SMOOTH & 21 & 6 & 9 \\
\hline DUERLAY & - AUERAGE & 22 & 5 & $7,8,19,25$ \\
\hline OUERLAY & - ROUGH & 23 & 4 & 22 \\
\hline$J R C$ & - SMOOTH & 31 & 11 & - \\
\hline JRC & - RUERAGE & 32 & 8 & 21,23 \\
\hline$J R C$ & - ROUGH & 33 & 7 & 20,24 \\
\hline CRC & - SMOOTH & 41 & 10 & $1,2,4,5,6$ \\
\hline CRC & - AUERAGE & 42 & 9 & 3 \\
\hline CRC & - ROUGH & 43 & 12 & - \\
\hline
\end{tabular}

Table 7: Revised Pavement TypeRoughness Groups

\begin{tabular}{|c|c|c|}
\hline $\begin{array}{l}\text { REUISED } \\
\text { PR GROUP }\end{array}$ & $\begin{array}{l}\text { EARL IER } \\
\text { PR GROUP }\end{array}$ & PR COMBINATION \\
\hline 1 & $8,1,5,4$ & $\begin{array}{ll}\text { JRE } & \text {-RUERRGE } \\
\text { FLEXIBLE-ROUGH } \\
\text { OUERLRY - } \\
\text { OUUERRGE } \\
\text { OUERLYY -ROUGH }\end{array}$ \\
\hline 2 & 7,6 & $\begin{array}{ll}\text { JRC } & \text {-ROUGH } \\
\text { OUERLAY } & \text {-SMOOTH }\end{array}$ \\
\hline 3 & 3 & FLEXIBLE-SMOOTH \\
\hline 4 & 9,2 & $\begin{array}{lr}\text { CRC } & \text {-RUERRGE } \\
\text { FLEXIBLE-AUERAGE }\end{array}$ \\
\hline 5 & 10 & -SMOOTH \\
\hline
\end{tabular}


A test on the regression procedure showed that merging the $10 \mathrm{PR}$ groups into 5 PR groups did not change the sum of squares explained by the air temperature. Further analysis on the basis of the revised 5 PR groups showed that air temperature has a significant effect on the roadmeter output, and the degree of this effect is different for each $P R$ group. The regression coefficients for the 5 pavement type-roughness groups are given in Table B2 of Appendix B and plotted in Figure 7. Figure 7 reveals the following:

(1) Air temperature has a very appreciable effect on roughness measurements of CRC pavements. If the measurements are recorded at $60^{\circ} \mathrm{F}$ and the mean roughness is of the order of 500 counts per kilometer, the effect could be as high as $35 \%$.

(2) When the roughness measurements are taken on flexible pavements with average and low roughnesses, the RM output is moderately affected by the air temperature. For a temperature of $60^{\circ} \mathrm{F}$, the effect is of the order of $20 \%$ to $25 \%$.

(3) The effect of air temperature on the RM output is least in the case of rough flexible pavements, all overlay pavements and JRC pavements with average and high roughness. This effect will range from $5 \%$ to $15 \%$.

Effect of Driver Type. The analys is of data showed that the roadmeter output will always be less when the vehicle is driven by a steady driver. The driver effect component in the output was found to be of the order of $3 \%$, on the average.

In this study the two drivers were selected on the basis of age. The younger driver was 22 years old and quite independent with a liberal view of life, while the older one was 33 years old and considerably 


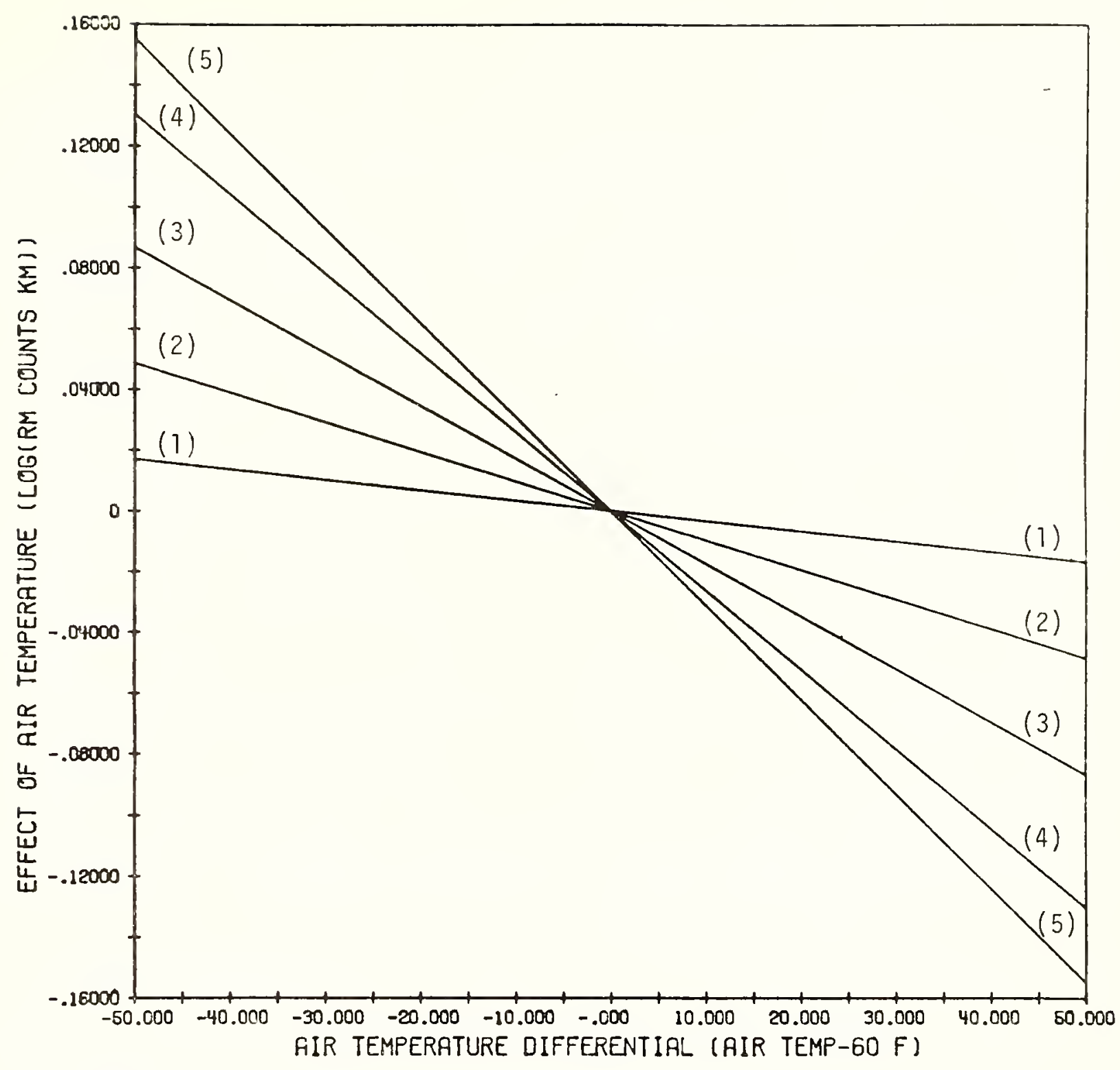

Legend

(1) Flexible-Rough Pavements

Overlay-Average Pavements

Overlay-Rough Pavements

JRC-Average Pavements

(2) Overlay-Smooth Pavements JRC-Rough Pavements

(3) Flexible-Smooth Pavements

(4) Flexible-Average Pavements CRC-Average Pavements

(5) CRC-Smooth Pavements

Figure 7: Effect of Air Temperature on Roadmeter Output for Various Pavement Type - Roughness Groups 


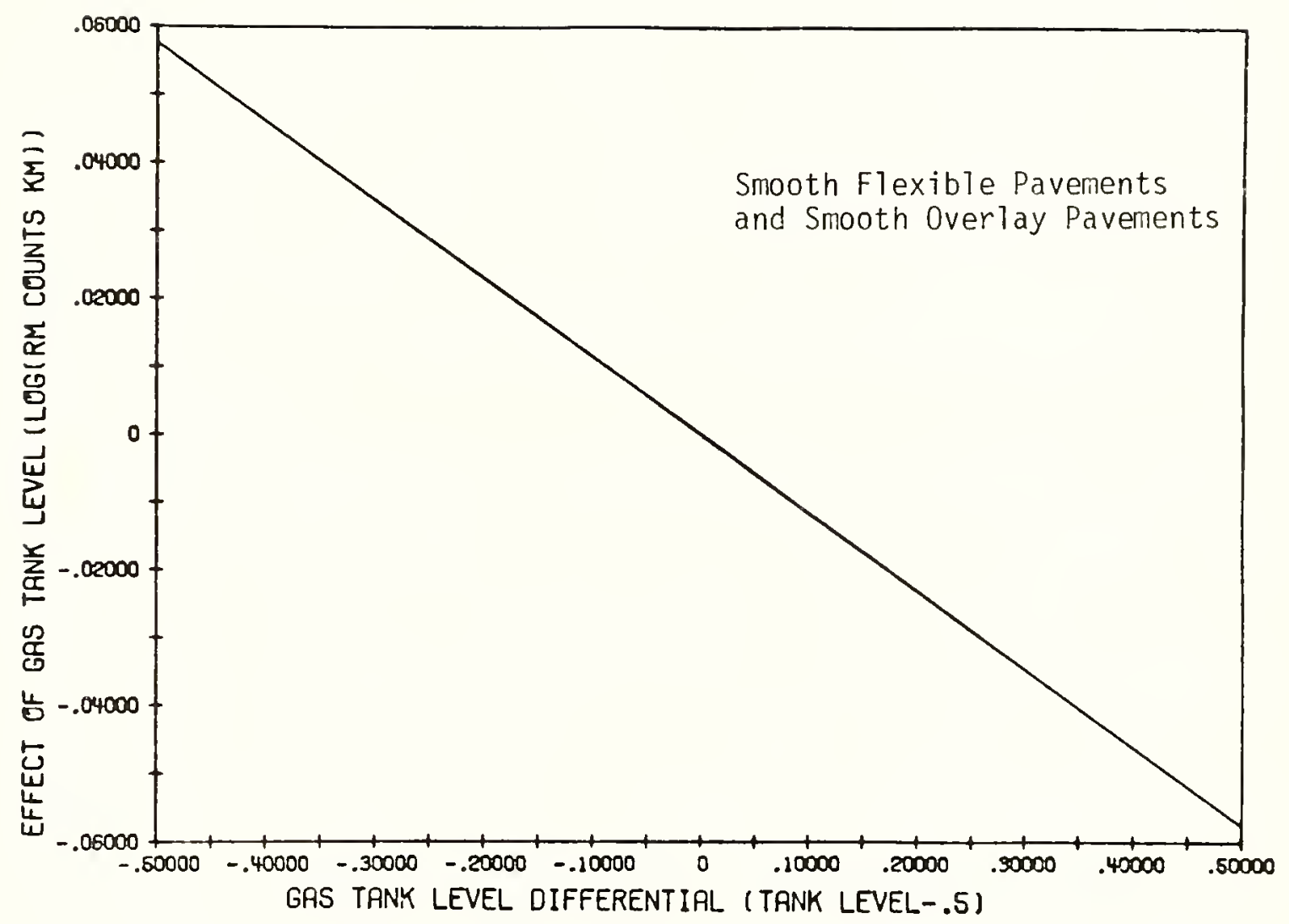

Figure 8: Effect of Gas Tank Level on Roadmeter Output 
more conservative. However, the steadiness in driving cannot always be related to age, personality, or view of life. In fact it is impossible to measure the driving steadiness of a person. However, the study has revealed that steadiness in driving has a significant effect on the RM output. The regression coefficient was .01467 with a positive sign for a younger driver. This effect can be offset by always resorting to a driver type with steady driving habits, and this recommendation has been included in the 'Standard Conditions for Roadmeter Operation', given in Appendix B.

Effect of Gas Tank Level. A detailed analysis of the data indicated that the effect of Gas Tank Level was found to be significant only for smooth overlay pavements and smooth flexible pavements.

Since two effects came out to be very close, they were merged into one. The regression coefficient for the effect of gas tank level for smooth overlay and smooth flexible pavements was .05757 , and is plotted in Figure 8.

Final Model. As a result of this study, the final model including the various factors found significant, was of the following form:

$$
\log _{10} Y^{\prime}=\log _{10} Y+B_{1}(T)+B_{2}^{*}(D)+B_{3}(L)
$$

where: $Y^{\prime}=$ Roadmeter output $(\Sigma C /$ kilometer $)$, as measured

$Y=$ True Roughness of a pavement section ( $E C /$ kilometer) $B_{1}=$ Coefficient for the effect of Temperature having values as
in Table $B 2$ of Appendix $B$.

$\mathrm{T}=$ Air Temperature in ${ }^{\circ} \mathrm{F}$ (valid range $15^{\circ} \mathrm{F}$ to $80^{\circ} \mathrm{F}$ )

$D$ = Driver Type $(+1$ for a non steady driver and 0 otherwise)

* In actual use, this factor may be dropped and this effect may be accounted for by always ensuring steady driving conditions. 
$B_{2}=$ Coefficient for the effect of driver type (.01467)

$\begin{aligned} B_{3}= & \text { Coefficient for the effect of Gas Tank Level (.05757 for } \\ & \text { smooth overlay pavements and smooth flexible pavements, }\end{aligned}$ and 0.0 for 017 other PR groups)

$L=$ Gas Tank Lever ( 0 to 1 ).

Number of Roadmeter Passes

To determine the number of roadmeter passes required on a pavement section for a reliable estimate of its roughness, an estimate of the error in measurement was required. Tests of homogeneity of variances on 25 sections showed that variances were not homogeneous at $\alpha=.01$ and therefore the errors of 25 test-sections could not be pooled to one common error. A grouping of the 25 test-sections into equal error groups was thus required. Keeping in view the applicability of this study to other pavement-sections, 12 pavement type-roughness groups were first formed as in Table 6 . As the variances within each of these 12 groups were found to be homogeneous, a further grouping to minimize the number of equal error groups was attempted. Many iterations gave a minimum of 5 such groups, as shown in Table B3 of Appendix B, and summarized in Table 8.

Computations for the Number of RM Passes

$$
\text { If } \begin{array}{rlrl}
\alpha & =\text { probability of Type I* error } & \sigma & =\text { Error of measurement } \\
\beta & =\text { probability of Type II** errorr } & C=\text { Acceptable error }
\end{array}
$$

Type I error is the probability of rejecting the average (X) of $N$ number of RM passes as an estimate of the true roughness $(\mu)$ of road surface when, in fact, it is. Type $I$ error is also termed as $\alpha$ error.

**Type II error is the probability of accepting the average ( $\bar{X}$ ) of $N$ number of RM passes as an estimate of the true roughness ( $\mu$ ) of road surface when, in fact, it is not. Type II error is also termed as B error. 
Table 8: Pavement Type-Roughness Groups Having Equal Error of Roadmeter Measurements

\begin{tabular}{|c|c|c|c|c|}
\hline $\begin{array}{l}\text { EDUAL } \\
\text { ERROR } \\
\text { GROUP }\end{array}$ & $\begin{array}{l}\text { PAUEMENT TYPE } \\
\text {-ROUEHIYESS } \\
\text { COMBINATION }\end{array}$ & $\begin{array}{l}\text { MEPN } \\
\text { RDUGHNESS } \\
(\Sigma \mathrm{C} / \mathrm{KM}) \\
\end{array}$ & $\begin{array}{l}\text { POOLED } \\
\text { STANDFIRD } \\
\text { EEUIATIONY } \\
\text { (ERRCR) } \\
\end{array}$ & $\begin{array}{l}\text { PERCENT } \\
\text { ERRCR }\end{array}$ \\
\hline 1 & FLEXIBLE-ROUGH & 2932.62 & 215.22 & 7.0 \\
\hline 2 & $\begin{array}{l}\text { FLEXIBLE-AUERAGE } \\
\text { CF:C - AUERAGE }\end{array}$ & 1238.34 & 170.71 & 13.0 \\
\hline 3 & $\begin{array}{lr}\text { FLEXIBLE-SMOOTH } \\
\text { CRC } & \text {-SMOOTH }\end{array}$ & 615.22 & 82.29 & 13.0 \\
\hline 4 & $\begin{array}{ll}\text { DUERLAY } & \text {-ROUGH } \\
\text { JRC } & \text {-ROUCH } \\
\text { JRC } & \text {-AUERACE }\end{array}$ & 1202.15 & 64.22 & 5.0 \\
\hline 5 & $\begin{array}{l}\text { DUERLAY -AUERACE } \\
\text { DUERLAY -SMOOTH }\end{array}$ & 386.51 & 32.58 & 8.0 \\
\hline
\end{tabular}


then, the acceptable error (C) will be one-half of the central $1-\alpha$ confidence interval. For 1-tailed tests, this error with desired controls over both $\alpha$ and $\beta$ errors will be given by (8):

$$
c=\frac{\left(t_{\alpha}+t_{\beta}\right) \sigma}{\sqrt{N}}
$$

and thus the number of RM passes will be:

$$
N=\left[\frac{\left(t_{\alpha}+t_{\beta}\right) \sigma}{c}\right]^{2}
$$

The number of roadmeter passes for the 5 equal error groups, calculated from Eq. (6) above for different combinations of Type I and Type II errors and for different values of acceptable errors are given in Table 9.

While rounding off the number of RM passes, decimal portions more than .09 were rounded off to one. Where the total value was less than .10 a minimum value of one was given.

Considerations in the Choice of $\alpha$ and $\beta$ Errors

The sole purpose of repetitive testing of a section of roadway to estimate pavement-roughness is to increase the accuracy of measurement. However, since each additional pass heavily taxes the already 1 imited resources of any State Highway Department, the desired accuracy should have some relationship with the purpose of the measurements, and should be justifiable in terms of added benefits. An economic analysis of the benefits of high accuracy versus the cost of additional passes will not lead to an appropriate solution to setting up an efficient measurement system as benefits of high accuracy cannot be quantified. Instead, a probabilistic approach having judicious control over Type I and Type II 
Table 9: Number of Roadmeter Passes for Various

Pavement Type-Roughness Groups

FLEXIBLE - ROUGH PAUEMENTS

\begin{tabular}{|c|c|c|c|c|c|c|c|c|c|c|c|c|c|}
\hline \multirow{2}{*}{$\begin{array}{l}\text { ACCEPTABLE } \\
\text { ERROR }(C / K M)\end{array}$} & \multirow{2}{*}{$\begin{array}{l}\alpha \\
\beta\end{array}$} & \multicolumn{4}{|c|}{.05} & \multicolumn{4}{|c|}{.1} & \multicolumn{4}{|c|}{.2} \\
\hline & & .05 & .1 & .2 & .5 & .05 & .1 & .2 & .5 & .05 & .1 & .2 & .5 \\
\hline 100 & & 60 & 47 & 35 & 15 & 47 & 35 & 25 & 9 & 35 & 25 & 17 & 4 \\
\hline 150 & & 27 & 21 & 16 & 7 & 21 & 16 & 11 & 4 & 16 & 11 & 8 & 2 \\
\hline 200 & & 15 & 12 & 9 & 4 & 12 & 9 & 7 & 3 & 9 & 7 & 4 & 1 \\
\hline 250 & & 10 & 8 & 6 & 3 & 8 & 5 & 4 & 2 & E & 4 & 3 & 1 \\
\hline 300 & & 7 & 6 & 4 & 2 & 6 & 4 & 3 & 1 & 4 & 3 & 2 & 1 \\
\hline 350 & & 5 & 4 & 3 & 2 & 4 & 3 & 2 & 1 & 3 & 2 & 2 & 1 \\
\hline 400 & & 4 & 3 & 3 & 1 & 3 & 3 & 2 & 1 & 3 & 2 & 1 & 1 \\
\hline 500 & & 3 & 2 & 2 & 1 & 2 & 2 & 1 & 1 & 2 & 1 & 1 & 1 \\
\hline
\end{tabular}

FLEXIBLE - RUERAGE PAUEMENTS

CRC - AUERAGE PRUEMENTS

\begin{tabular}{|c|c|c|c|c|c|c|c|c|c|c|c|c|c|}
\hline \multirow{2}{*}{$\begin{array}{l}\text { ACCEPTABLE } \\
\text { ERROR ( } C / K M)\end{array}$} & \multirow{2}{*}{$\alpha$} & \multicolumn{4}{|c|}{.05} & \multicolumn{4}{|c|}{.1} & \multicolumn{4}{|c|}{.2} \\
\hline & & .05 & .1 & .2 & .5 & .05 & .1 & .2 & .5 &.$\overline{05}$ & .1 & .2 & .5 \\
\hline 50 & & 151 & 117 & 88 & 38 & 117 & 87 & 62 & 22 & 88 & 52 & 42 & 11 \\
\hline 100 & & 38 & 29 & 22 & 10 & 29 & 22 & 16 & 6 & 22 & 16 & 11 & 3 \\
\hline 150 & & 17 & 13 & 10 & 5 & 13 & 10 & 7 & 3 & 10 & 7 & 5 & 2 \\
\hline 200 & & 10 & 8 & 6 & 3 & 8 & G & 4 & 2 & 6 & 4 & 3 & 1 \\
\hline 250 & & 6 & 5 & 4 & 2 & 5 & 4 & 3 & 1 & 4 & 3 & 2 & 1 \\
\hline 300 & & 5 & 4 & 3 & 1 & 4 & 3 & 2 & 1 & 3 & 2 & 2 & 1 \\
\hline 350 & & 3 & 3 & 2 & 1 & 3 & 2 & 2 & 1 & 2 & 2 & 1 & 1 \\
\hline 400 & & 3 & 2 & 2 & 1 & 2 & 2 & 1 & 1 & 2 & 1 & 1 & 1 \\
\hline
\end{tabular}


Table 9: continued

FLEXIBLE - 5MOOTH PAUEMENTS

CRC - SMOOTH PAUEMENTS

\begin{tabular}{|c|c|c|c|c|c|c|c|c|c|c|c|c|c|}
\hline \multirow{2}{*}{$\begin{array}{l}\text { ACCEPTABLE } \\
\text { ERROR }(\mathrm{C} / \mathrm{KM})\end{array}$} & \multirow{2}{*}{$\begin{array}{l}\alpha \\
\beta\end{array}$} & \multicolumn{4}{|c|}{.05} & \multicolumn{4}{|c|}{.1} & \multicolumn{4}{|c|}{.2} \\
\hline & & .05 & .1 & .2 & .5 & .05 & .1 & .2 & .5 & .05 & .1 & .2 &.$\overline{5}$ \\
\hline 25 & & 140 & 109 & 81 & 35 & 109 & 81 & 58 & 21 & 81 & 58 & 39 & 10 \\
\hline 50 & & 35 & 27 & 21 & 9 & 27 & 21 & 15 & 5 & 21 & 15 & 10 & 3 \\
\hline 75 & & 16 & 12 & 9 & 4 & $\Gamma_{12}$ & -9 & 7 & 3 & 3 & 7 & 5 & 1 \\
\hline 100 & & 9 & 7 & 5 & 3 & 7 & 5 & 4 & 2 & 5 & 4 & 3 & 1 \\
\hline 125 & & 6 & 5 & 4 & 2 & 5 & 4 & 3 & 1 & 4 & 3 & 2 & 1 \\
\hline 150 & & 4 & 3 & 3 & 1 & 3 & 3 & 2 & 1 & 3 & 2 & 1 & 1 \\
\hline 175 & & 3 & 3 & 2 & 1 & 3 & 2 & 2 & 1 & 2 & 2 & 1 & 1 \\
\hline 200 & & 3 & 2 & 5 & 1 & 12 & 2 & 1 & 1 & 12 & 1 & 1 & 1 \\
\hline
\end{tabular}

OUERLAY - ROUGH PAUEMENTS

JRC - ROUGH PAUEMENTS

JRC - AUERAGE PAUEMENTS

\begin{tabular}{|c|c|c|c|c|c|c|c|c|c|c|c|c|c|}
\hline \multirow{2}{*}{$\begin{array}{l}\text { ACCEPTABLE } \\
\text { ERROR }(\mathrm{C} / \mathrm{KM})\end{array}$} & \multirow{2}{*}{$\begin{array}{l}\alpha \\
\beta \\
\end{array}$} & \multicolumn{4}{|c|}{.05} & \multicolumn{4}{|c|}{.1} & \multicolumn{4}{|c|}{.2} \\
\hline & & .05 & .1 & .2 & .5 & .05 & .1 & .2 & .5 & .05 & .1 & .2 & .5 \\
\hline 20 & & 133 & 103 & 78 & 34 & 103 & 77 & 55 & 20 & 78 & 55 & 37 & 9 \\
\hline 40 & & 34 & 26 & 20 & 9 & 26 & 20 & 14 & 5 & 20 & 14 & 9 & 3 \\
\hline 60 & & 15 & 12 & 9 & 4 & 12 & 9 & 6 & 3 & 9 & 6 & 4 & 1 \\
\hline 80 & & 9 & 7 & 5 & 2 & 7 & 5 & 4 & 2 & 5 & 4 & 3 & 1 \\
\hline 100 & & 6 & 5 & 3 & 2 & 5 & 3 & 3 & 1 & 3 & 3 & 2 & 1 \\
\hline 120 & & 4 & 3 & 3 & 1 & 3 & 3 & 2 & 1 & 3 & 2 & 1 & 1 \\
\hline 140 & & 3 & 2 & 2 & 1 & 2 & 2 & 2 & 1 & 2 & 2 & 1 & 1 \\
\hline 160 & & 2 & 2 & 2 & 1 & 2 & 2 & 1 & 1 & 2 & 1 & 1 & 1 \\
\hline
\end{tabular}


Table 9: continued

DUERLAY - AUERAGE PAUEMENTS

DUERLAY - SMOOTH PAUEIIENTS

\begin{tabular}{|c|c|c|c|c|c|c|c|c|c|c|c|c|c|}
\hline \multirow{2}{*}{$\begin{array}{l}\text { ACCEPTABLE } \\
\text { ERRDR (C } / \text { KM })\end{array}$} & \multirow{2}{*}{$\begin{array}{l}\alpha \\
\beta\end{array}$} & \multicolumn{4}{|c|}{.05} & \multicolumn{4}{|c|}{1} & \multicolumn{4}{|c|}{.2} \\
\hline & & .05 & .1 & .2 & .5 & .05 & .1 & .2 & .5 & .05 & .1 & .2 & .5 \\
\hline 10 & & 137 & 106 & 80 & 35 & 106 & 79 & 57 & 20 & 80 & 57 & 38 & 10 \\
\hline 20 & & 35 & 27 & 20 & 9 & 27 & 20 & 14 & 5 & 20 & 14 & 10 & 3 \\
\hline 30 & & 16 & 12 & 9 & 4 & 12 & 9 & 7 & 3 & 5 & 7 & 5 & 1 \\
\hline 40 & & 9 & 7 & 5 & 3 & 7 & 5 & $j_{4}$ & c & 15 & 4 & 13 & 1 \\
\hline 50 & & 6 & 5 & 4 & 2 & 5 & 4 & 3 & 1 & 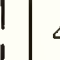 & 3 & 2 & 1 \\
\hline 60 & & 4 & 3 & 3 & 1 & 3 & 3 & 12 & 1 & 1 & 2 & 11 & 1 \\
\hline 80 & & 3 & 2 & 2 & 1 & 2 & 2 & 1 & 1 & $\dot{a}$ & 1 & 1 & 1 \\
\hline 100 & & 2 & 1 & 1 & 1 & 1 & 1 & 11 & 1 & 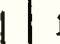 & 1 & 1 & 1 \\
\hline
\end{tabular}

Note: Portions of the above tables within the solid boxes are the reasonable ranges of $\alpha$ and $\beta$ risks, and acceptable errors recommended for use in maintenance planning. Portions of tables within dotted boxes are recommended for use in construction quality control. 
errors should determine the number of RM passes, using different Type I and Type II errors for each different purpose.

Purposes of Pavement Roughness Measurements. Roughness measurements of a pavement surface using RM are usually required for the following purposes:

(1) Pavement Maintenance Planning. Pavement roughness is an indicator of the serviceability or functional capability of the pavement and is thus used in planning major maintenance. Visibly smooth pavements will not be of any practical interest for this activity and therefore any measurement accuracy should refer to average and rough pavements.

In the case of average and rough pavements only those pavements that are well above the decision roughness level* (hereafter called DRL) will be of interest. However, pavements which have roughness values below the DRL should be rejected. In this case the hypothesis will be of the form:

$$
\begin{aligned}
& H_{0}: \quad \mu>\mu_{0} \\
& H_{1}: \quad \mu \leq \mu_{0}
\end{aligned}
$$

and it will be quite desirable to have very high $\alpha$ errors, and low $B$ errors. The number of roadmeter passes for these $\alpha$ and $\beta$ risks and for reasonable ranges of acceptable errors are shown as boxed with solid lines in Table 9.

\footnotetext{
*Decision Roughness Level (DRL) is here defined as that level of roughness above which a pavement is considered a candidate for overlay from the point of view of roughness.
} 
(2) Construction Quality Control. Another important use of roughness measurements is to check the riding quality of a newly constructed pavement. In this case the following hypothesis is tested:

$$
\begin{aligned}
& H_{0}: \mu \leq \mu_{0} \\
& H_{1}: \mu>\mu_{0}
\end{aligned}
$$

The state highway department will desire a very small risk in accepting a pavement which in fact has a roughness count above the specified limits. Therefore, low values of $\beta$, say .05 and .1 , will perhaps be appropriate. Since the highway department can afford the risk of rejecting a pavement which in fact has a roughness count below the specified limits, a values of .1 and .2 will be acceptable.

The number of roadmeter passes for these $\alpha$ and $\beta$ risks and for reasonable ranges of acceptable errors are shown as boxed with dotted lines in Table 9.

\section{Standard Conditions for Roadmeter Operation}

Based on this study and other researches done in this area, conditions for operating the ISHC Roadmeter have been standardized and are detailed in Appendix B. The adjustments for air temperature and gas tank level as proposed in this study are valid only when the roadmeter is operated under these standard conditions. Also, the pavement serviceability studies in Chapter 4 are based on RM data collected under these standard conditions. 


\section{Summary - Roadmeter Variability Study}

Utility of Roadmeter

From data obtained in this study the roadmeter is a very suitable instrument for measuring the longitudinal roughness of a pavement surface. In this study $97.9 \%$ of the variation between test sections was explained by the roadmeter measurements. It is highly recommended for use in the planning of pavement maintenance in the short run as well as in the long run, for construction quality control, for locating abnormal stretches and for measuring pavement performance. After calibration against human ratings, it is capable of reproducing the present serviceability ratings within a desirable degree of accuracy. Coupled with other pavement characteristics, these measurements can be very useful in the design and rehabjlitation of pavement systems.

Adjustment of RIM Measurements

for the Effect of Influencing Variables

Of the three factors (air temperature, gas tank leve] and driver type) examined in this study for their effect on the roadmeter output, all the three were found significant. It is recommended that measurements taken at any time of the year be adjusted for the effects of these influencing variables and normalized to some standard value of each variable so that the roughness measured in one season can be compared with the roughness of the same section obtained in another season. Also, the roughness measured in the same season but at various values of air temperature, gas tank level and driver type can be adjusted to compare to the standard values. The recommended standard values of these variables are given in Table 10 . 
Table 10: Recommended Standard Values of Influencing Factors

\begin{tabular}{lc}
\hline Factor & $\begin{array}{c}\text { Recommended } \\
\text { Standard Value }\end{array}$ \\
\hline Air Temperature & $60^{\circ} \mathrm{F}$ \\
Driver Type & Steady \\
Gas Tank Level & $1 / 2 \mathrm{Full}$ \\
\hline
\end{tabular}

(i) Effect of Air Temperature was found to be significant and different for different pavement type-roughness groups. The temperature effect on the RM measurements of CRC pavements was found to be most pronounced and can be as high as $35 \%$, and was found to be least in the case of Flexible-Rough pavements. The air temperature effects for various PR groups are plotted in Figure 7.

(ii) Effect of Driver Type. The study showed that a steady driver will always get about 3\% 1ess RM measurements than a nonsteady driver. But since the steadiness of a driver is not measurable, this effect should be taken care of by always resorting to steady driving conditions.

(iii) Effect of Gas Tank Level was found to be significant only for smooth overlay pavements and smooth flexible pavements. These effects are plotted in Figure 8. When the gas tank is ful1, the effect of gas tank level can be as high as $12 \%$.

\section{Number of Roadmeter Passes}

Based on an average of 12 RM runs, the measurement errors were found to vary from $5 \%$ to $13 \%$ depending upon the pavement type-roughness group. These errors for each PR group are shown in Table 8. 
When the measurement error is known the number of roadmeter passes becomes a function of Type I error, Type II error and the Acceptable error, and is calculated by Equation (6). The number of passes required for various conceivable values of Type I error, Type II error and acceptable errors are given in Table 9.

The philosophy of selecting appropriate values of $\alpha$ and $\beta$ risks should be guided by the purpose of roughness measurements. For maintenance planning and construction quality control, high a risks (perhaps of the order of .2) and low $\beta$ risks (perhaps of the order of .05 and .1) are recommended. With these $\alpha$ and $\beta$ risks, the number of RM passes will range from 1 to 8 . 


\section{CHAPTER 3: SELECTION OF TEST SECTIONS}

\section{Delineation of Study Area}

Although the results of this research are intended to have statewide applicability, it was not feasible to do extensive work on pavement sections located throughout the state. Since the two organizations associated with this research, Purdue University and the Research \& Training Center of the Indiana State Highway Commission, are both located at West Lafayette, it was decided to limit the size of the area having its center at West Lafayette, within a radius of 70 miles. The area studied was considered optimum in terms of travel time and at the same time included a sufficiently wide inference space in terms of climate, soil types, pavement types and roughness groups.

\section{Coding of State Highway System}

To protect against any bias in the experiment a random selection of test sections was necessary (2). It was decided that each test section was to be one kilometer long. The records of the Indiana State Highway Commission, however, showed all distances in miles. It was, therefore, decided to randomly select sections of one mile length and then to locate the one kilometer long test sections within the selected miles. 
To accomplish the above, it was necessary to represent the total mileage in the state (about 11,000 miles) by a unique number; and this coding was accomplished as detailed in the following steps.

1. The inventory of bridges (28) maintained by the Indiana State Highway Commission gives the mile post of all the bridges and county lines falling on each route of the state highway system. Each northsouth route begins from its southern end and each east-west route begins from its western end. From this record the length of each route within each county was computed and tabulated as in Table 11.

2. All of the state highways were then listed in ascending order of their route numbers. State routes (SR1 to SR912) were listed first, followed by US routes (US6 to US460) and then by Interstate routes ( I64 to I465). For example the northbound lane of SR1, which was 181 miles long, was coded as 1 to 181 and the southbound lane was coded as 2 to 362. Thus, each mile of both outer lanes of SRI was represented by a unique number from 1 to 362 , as in Table 12 . The east bound 1ane of SR2 was next coded as 363 to 440 and its west bound lane from 441 to 518. Proceeding in this manner, both outer lanes of each highway were coded such that each lane-mile was represented by a unique number from 1 to 22578.

\section{Random Selection of the Test Sections}

The total number of lane-miles from which a random sample could be drawn was 22578. For a 10\% sample, 2258 random numbers between 1 and 22578 were generated and with the help of Table 11 and 12 , route number and mile within each route corresponding to every random number was determined. For illustration, assume a random number 15410 was 
Table 11: Breakdown of Routes of the

Indiana State Highway Commission

\begin{tabular}{|c|c|c|c|c|c|c|c|c|}
\hline & & GROSS LE & ENGTH & & FOLLOI & & & \\
\hline & ROUTE & COUNTY & MILES & ROUTE & LENGTH & BETWEEN & LENGTH & I LENGTH \\
\hline SR1 & & & & & & & & \\
\hline 0.0 & JCT US50 & DEARBORN & 18.54 & & & & 18.54 & 18.54 \\
\hline & & $\begin{array}{l}\text { FRANKLIN } \\
\text { FAYETTE }\end{array}$ & $\begin{array}{l}19.33 \\
15.02\end{array}$ & USS2 & 6.85 & $4.28-11.13$ & $\begin{array}{l}12.48 \\
15.02\end{array}$ & $\begin{array}{l}31.02 \\
46.04\end{array}$ \\
\hline & & WAYNE & 21.74 & SR38 & 0.79 & $14.06-14.85$ & 20.95 & 66.99 \\
\hline & & RANDOLPH & 23.05 & SR32 & 1.16 & $12.79-14.13$ & 21.89 & 88.88 \\
\hline & & $\begin{array}{l}\text { JAY } \\
\text { WELLS }\end{array}$ & $\begin{array}{l}18.03 \\
24.30\end{array}$ & & & & $\begin{array}{l}18.03 \\
24.30\end{array}$ & $\begin{array}{l}106.91 \\
131.21\end{array}$ \\
\hline & & ALLEN & 31.54 & US27 & 7.38 & $9.15-16.53$ & 20.61 & 151.82 \\
\hline & & DEKALB & 21.98 & $\begin{array}{l}\text { I-69 } \\
\text { SR8 }\end{array}$ & $\begin{array}{l}3.55 \\
1.01\end{array}$ & $\begin{array}{c}16.53-20.08 \\
8.06-9.07\end{array}$ & 20.97 & 172.79 \\
\hline END & JCT US20 & STEUBENY & 8.17 & & & & 8.17 & 180.96 \\
\hline SR2 & & & & & & & & \\
\hline 0.0 & $\begin{array}{l}\text { IND-ILL } \\
\text { STATE LINE }\end{array}$ & $\begin{array}{l}\text { LAKE } \\
\text { PDRTER }\end{array}$ & $\begin{array}{l}19.09 \\
26.34\end{array}$ & $\begin{array}{l}\text { US41 } \\
\text { US231 } \\
\text { US30 }\end{array}$ & $\begin{array}{l}2.64 \\
2.17 \\
1.49\end{array}$ & $\begin{array}{c}3.42-6.06 \\
1.01-3.18 \\
16.64-18.13\end{array}$ & 16.45 & 16.45 \\
\hline & & & & SR 49 & 0.34 & $18.13-18.47$ & 22.34 & 38.79 \\
\hline & & LAPORTE & 26.21 & US421 & 1.01 & $2.13-3.14$ & 25.20 & 63.99 \\
\hline $\begin{array}{l}\text { END } \\
\text { AND }\end{array}$ & $\begin{array}{l}\text { JCT US31 } \\
\text { US33 }\end{array}$ & ST JOSEPH & 14.31 & & & & 14.31 & 78.20 \\
\hline SR3 & & & & & & & & \\
\hline 0.0 & JCT SR62 & $\begin{array}{l}\text { CLARK } \\
\text { SCOTT } \\
\text { JEFFERSON }\end{array}$ & $\begin{array}{r}24.58 \\
10.84 \\
\text { Y } 5.70\end{array}$ & $\begin{array}{l}\text { SR62 } \\
\text { SR56 }\end{array}$ & $\begin{array}{r}12.35 \\
3.02\end{array}$ & $\begin{array}{c}00.00-12.35 \\
6.17-9.19\end{array}$ & $\begin{array}{r}12.23 \\
7.82 \\
6.70\end{array}$ & $\begin{array}{l}12.23 \\
20.05 \\
26.75\end{array}$ \\
\hline & & JEHNINGS & 22.83 & SR7 & 3.17 & $11.37-14.54$ & 18.66 & 45.41 \\
\hline & & DECATUR & 27.95 & $\begin{array}{l}\text { SR46 } \\
\text { US421 }\end{array}$ & 5.61 & $14.27-19.88$ & 22.34 & 66.75 \\
\hline & & $\begin{array}{l}\text { RUSH } \\
\text { HENRY }\end{array}$ & $\begin{array}{l}23.90 \\
22.41\end{array}$ & U552 & 0.42 & $10.98-11.40$ & $\begin{array}{l}23.48 \\
22.41\end{array}$ & $\begin{array}{r}91.23 \\
113.64\end{array}$ \\
\hline & & DELALIARE & 21.96 & & & & 21.96 & 135.60 \\
\hline & & BLACKFORD & 13.00 & & & & 13.00 & 148.60 \\
\hline END & SECTION 1 & $\begin{array}{l}\text { WUELLS } \\
\text { HUNTINGTON }\end{array}$ & $\begin{array}{r}6.01 \\
12.58\end{array}$ & & & & $\begin{array}{r}6.01 \\
12.58\end{array}$ & $\begin{array}{l}154.61 \\
167.19\end{array}$ \\
\hline & $\begin{array}{l}\text { JCT : SR224 } \\
\text { SECTION ? }\end{array}$ & ALLEN & 10.47 & & & & 10.47 & 10.47 \\
\hline & JCT 169 & NOBLE & 19.56 & US6 & 0.60 & $13.74-14.34$ & 18.96 & 29.43 \\
\hline END & JCT SRI20 & LAGRANGE & 14.57 & & & & 14.57 & 44.00 \\
\hline & * & * & * & * & * & * & * & \\
\hline & * & * & * & * & * & * & * & * \\
\hline & * & * & * & * & * & * & * & * \\
\hline $\begin{array}{l}\text { SR91 } \\
0 . D \\
\text { AND } \\
\text { END }\end{array}$ & $\begin{array}{l}\frac{12}{J C T} \text { US12 } \\
\text { USZO } \\
\text { JCT OLD USG }\end{array}$ & LAKE & 9.52 & & & & 9.52 & 9.52 \\
\hline US6 & & & & & & & & \\
\hline 0.0 & ILL.ST.LINE & LAKE & 18.21 & I80-90 & 15.29 & $00.00-15.29$ & 103 & 103 \\
\hline & & $\begin{array}{l}\text { PORTER } \\
\text { LAPORTE } \\
\text { ST.JOSEPH }\end{array}$ & $\begin{array}{r}15.18 \\
24.33 \\
3.56\end{array}$ & บ5421 & 1.09 & $1.96-3.05$ & $\begin{array}{r}14.09 \\
24.33 \\
3.56\end{array}$ & $\begin{array}{l}15.12 \\
39.45 \\
43.01\end{array}$ \\
\hline & & MARSHALL & 22.03 & & & & 22.03 & 65.04 \\
\hline & & ELKHART & 21.28 & & & & 21.28 & 86.32 \\
\hline & & NOBLE & 24.89 & & & & 24.89 & 111.21 \\
\hline END & OHIO ST.LINE & DEKALB & 20.83 & & & & 20.83 & 132.04 \\
\hline
\end{tabular}


Table 12: Coding of the State Highway System

\begin{tabular}{|c|c|c|c|}
\hline $\begin{array}{l}\text { STATE } \\
\text { HIGHWAY }\end{array}$ & $\begin{array}{l}\text { LENGTH } \\
\text { (MILES) }\end{array}$ & $\begin{array}{l}\text { RANEE DF } \\
N / E \text { LANE }\end{array}$ & $\begin{array}{c}\text { CODE NUMBERS } \\
\text { S/W LANE }\end{array}$ \\
\hline SR 1 & 180.96 & $1-181$ & $182-362$ \\
\hline SR 2 & 78.20 & $363-440$ & $441-518$ \\
\hline * & * & * & * \\
\hline * & * & * & * \\
\hline * & * & * & * \\
\hline SR 5 & 74.21 & $1017-1090$ & $1091-1164$ \\
\hline $\mathrm{SR} 7$ & 45.38 & $1165-1209$ & $1210-1254$ \\
\hline * & * & * & * \\
\hline * & * & * & * \\
\hline * & * & * & * \\
\hline SR 650 & 0.90 & $15359-15359$ & $15360-15360$ \\
\hline SR 662 & 4.62 & $15361-15365$ & $15366-15370$ \\
\hline $5 R 727$ & 0.79 & $15371-15376$ & $15372-15372$ \\
\hline SR 827 & 7.16 & $15373-15379$ & $15380-15386$ \\
\hline SR 912 & 9.52 & $15387-15396$ & $15397-15406$ \\
\hline US 6 & 132.04 & $15407-15538$ & $15539-15670$ \\
\hline US 12 & 45.41 & $15671-15715$ & $15716-15760$ \\
\hline US 20 & 143.72 & $15761-15904$ & $15905-16048$ \\
\hline US 24 & 157.25 & $16049-16205$ & $16206-16362$ \\
\hline US 27 & 134.18 & $16383-16496$ & $16497-16630$ \\
\hline US 30 & 151.01 & $16631-16781$ & $16782-16932$ \\
\hline US $31 E$ & 6.98 & $16933-16939$ & $16940-16946$ \\
\hline US $31 \mathrm{~W}$ & 8.84 & $16947-16955$ & $16956-16964$ \\
\hline * & * & * & $\star$ \\
\hline * & * & * & * \\
\hline * & $*$ & * & * \\
\hline US 52 & 144.83 & $19461-19605$ & $19605-19750$ \\
\hline US 136 & 74.32 & $19751-19824$ & $19825-19898$ \\
\hline US 150 & 73.71 & $19899-19972$ & $19973-20046$ \\
\hline U5 224 & 39.67 & $20047-20086$ & $20087-20126$ \\
\hline US 231 & 70.75 & $20127-20197$ & $20198-20268$ \\
\hline US 421 & 188.83 & $20269-20457$ & $20458-20646$ \\
\hline US 460 & 3.48 & $20647-20649$ & $20650-20652$ \\
\hline I 64 & 124.00 & $20653-20776$ & $20777-20900$ \\
\hline I 65 & 262.34 & $20901-21162$ & $21163-21424$ \\
\hline I 69 & 158.63 & $21425-21583$ & $21584-21742$ \\
\hline I 70 & 152.89 & $21743-21895$ & $21896-22048$ \\
\hline I 74 & 151.94 & 22049-22200 & 22201-22352 \\
\hline I 94 & 45.32 & 22353-22397 & $22398-22442$ \\
\hline I 265 & 6.70 & $22443-22449$ & $22450-22456$ \\
\hline I 275 & 2.0 & 22457-22458 & $22459-22460$ \\
\hline I 465 & 59.20 & 22451-22519 & 22520-22578 \\
\hline
\end{tabular}


generated. Table 12 shows that this number belongs to the east bound lane of US6 and is 3 miles (15410-15407) east of the beginning of the east bound lane. From the route details of US6 in Table 11, it can be seen that the location 3 miles east of the beginning of US 6 falls in Porter county and is 1.97 (3-1.03) miles east of county line. Proceeding in this manner, each of the 2258 random numbers was related to the corresponding range of code numbers for a particular route and then to a particular mile within that route. Correspondence of each random number was tabulated as illustrated in Table 13. These mile long sections were then located on the Indiana state highway map and those sections which fell within the study area were determined.

The randomly selected test sections were ultimately arranged in travel loops for efficiency in data collection. It was anticipated the $10 \%$ sample would set the direction for establishing the test loops. This, however, was not achieved as the points representing the test sections were spread more or less uniformly in the study area. A 5\% sample was next drawn and plotted as in Figure 9. This plot showed a nonuniform scatter of points and led to the formation of the travel 10ops.

\section{Pavement Data Collection}

The test sections selected in this phase were used for the

(1) Pavement Serviceability Studies, (2) Deflection Studies, and

(3) Skid Studies.

The selected pavement sections were screened for their relevant properties so that all levels of influencing factors would be included in this experiment. It was decided that a larger number of test 
Table 13: Location Details of Random Numbers

\begin{tabular}{|c|c|c|c|c|c|}
\hline $\begin{array}{l}\text { SERIAL } \\
\text { NUMBER }\end{array}$ & $\begin{array}{l}\text { RAMDOM } \\
\text { NUMBER }\end{array}$ & ROUTE & COUNTY & $\begin{array}{l}\text { DIST FROM } \\
\text { COUNTY LINE }\end{array}$ & LANE \\
\hline 1 & 1532 & SR9 & HUNTINGTON & 11.8 & $W B$ \\
\hline 2 & 9002 & SRG2 & POSEY & 0.0 & $E B$ \\
\hline 3 & 20454 & US421 & LAPORTE & 28.3 & NB \\
\hline 4 & 4020 & SR26 & CLINTON & 5.1 & $E B$ \\
\hline 5 & 18305 & US40 & PUTNAM & 9.1 & $E B$ \\
\hline 6 & 19788 & US136 & MONTGOMERY & 12.2 & $E B$ \\
\hline 7 & 15344 & SR550 & MARTIN & 1.0 & $W B$ \\
\hline 8 & 9907 & SREG & PERRY & 45.9 & $W B$ \\
\hline 9 & 22250 & $I-74$ & SHELBY & 0.5 & $\omega B$ \\
\hline 10 & 11662 & SR121 & FRANKLIN & 2.1 & $S B$ \\
\hline 11 & 9955 & SRGG & UANDERBURGH & 5.3 & WB \\
\hline 12 & 17932 & US35 & CASS & 12.8 & $5 B$ \\
\hline 13 & 7106 & SR47 & HAMILTON & 6.0 & $E B$ \\
\hline 14 & 16945 & US31E & CLARK & 5.0 & WB \\
\hline 15 & 6376 & SR44 & SHELBY & 1.1 & SB \\
\hline 16 & 6054 & SR43 & TIPPECANOE & 3.1 & NB \\
\hline 17 & 2818 & SR1G & MIAMI & 8.2 & $E B$ \\
\hline 18 & 19934 & US 150 & ORANGE & 12.9 & NB \\
\hline 19 & 17791 & US35 & CASS & 23.1 & NB \\
\hline 20 & 205 & SR 1 & DEKALB & 14.8 & $\mathrm{SB}$ \\
\hline 21 & 5392 & SR38 & HAMILTON & 17.4 & EB \\
\hline 22 & 18545 & US 40 & CLAY & 7.1 & $W B$ \\
\hline 23 & 11687 & SR122 & WAYNE & 5.0 & WB \\
\hline 24 & 5582 & SR39I & WASHINGTON & 15.0 & $S B$ \\
\hline 25 & 5395 & 5R38 & MADISON & 0.0 & $E B$ \\
\hline 26 & 21012 & $I-65$ & MARION & 9.3 & NB \\
\hline 27 & 21242 & $I-65$ & TIPPECANOE & 1.6 & $\mathrm{SB}$ \\
\hline 28 & 10088 & SRET & MARION & 8.9 & NB \\
\hline 29 & 9116 & SRG2 & FLOYD & 3.4 & WB \\
\hline 30 & 12870 & SR164 & DUBOIS & 10.3 & WB \\
\hline 31 & 7545 & SR55 & NEWTON & 28.8 & NB \\
\hline 32 & 20320 & U5421 & DECATUR & 12.4 & $\mathrm{NB}$ \\
\hline 33 & 16619 & US27 & UNION & 2.0 & $S B$ \\
\hline 34 & 19392 & US50 & LAWRENCE & 11.4 & WB \\
\hline 35 & 8313 & SR58 & JACKSON & 13.1 & WB \\
\hline 36 & 20319 & US421 & DECATUR & 11.4 & NB \\
\hline 37 & 8342 & SR58 & GREENE & 7.4 & WB \\
\hline 38 & 8887 & SRG2 & PERRY & 13.4 & $E B$ \\
\hline 39 & 2127 & SR13 & KOSCIUSKO & 26.6 & NB \\
\hline 40 & 17951 & US35 & HOWARD & 1.3 & $S B$ \\
\hline 41 & 15410 & US6 & PORTER & 2.0 & $E B$ \\
\hline 42 & 1139 & SR5 & WHITLEY & 18.8 & $\mathrm{SB}$ \\
\hline * & * & * & * & * & * \\
\hline * & * & * & * & * & * \\
\hline * & * & * & * & * & * \\
\hline
\end{tabular}




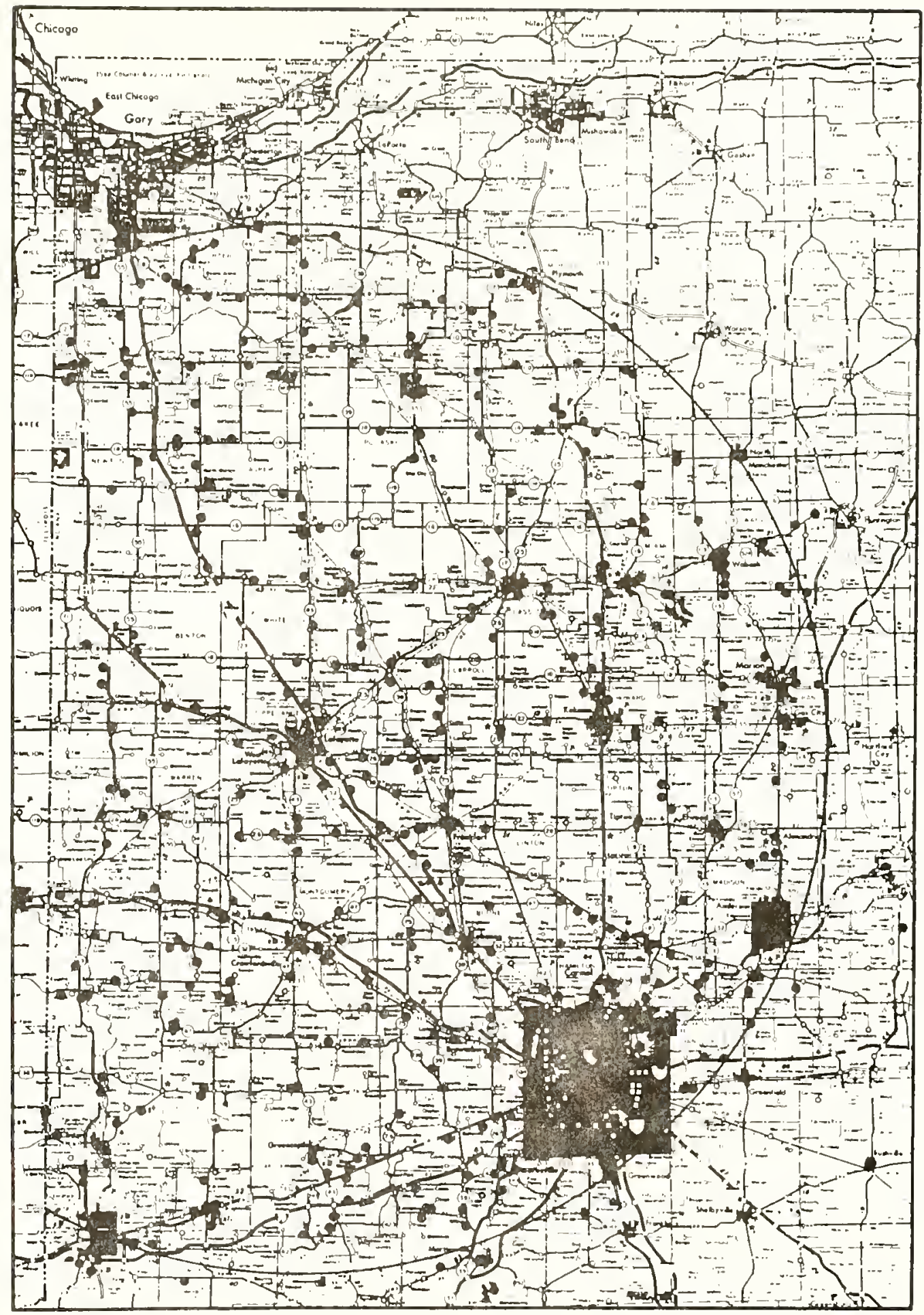

Figure 9: Five Percent Random Sample of Miles in the Study Area 
sections would be used for the pavement serviceability studies and that a sample from those test sections would be used for the deflection and skid studies.

The following data was collected for each pavement section:

1. Type of Facility

2. Type of Pavement

3. Width of Pavement

4. Pavement Condition

5. Width and Type of Shoulders

During the process of data collection, pavement sections which passed through towns, had speed restrictions, were not of uniform type, width or roughness and those which included railroad crossings or bridges were dropped.

\section{Formation of Travel Loops}

Since each test section included in this study was to be inspected many times it was desirable to arrange the sections in loops to minimize travel time. The following guidelines were formulated for formation of loops.

1. Length of loop was between 150 and 200 miles so that the loop could be travelled in $1 / 2$ day.

2. Loops should be spread in the whole study area and some of them should extend to the edges of study area to provide maximum inference with respect to climate and soil type.

3. Each loop should include as many randomly selected sections as possible.

4. Each loop should include test sections with as many test variables as possible. 
Final Selection and Listing of Test Sections

Ninety four test sections arranged in 5 loops were finally selected for the pavement serviceability studies. The broad properties of these test-sections are given in Table 14. The 94 test-sections were then plotted on maps, one for each loop, as shown in Figures $\mathrm{Cl}$ to C5 of Appendix $\mathrm{C}$ for convenience of the raters and data collection teams. Also location details of test sections were tabulated as in Tables $\mathrm{Cl}$ to $\mathrm{C} 5$ of Appendix C.

Table 14: Broad Properties of the 94 Test Sections

\begin{tabular}{|c|c|c|c|c|c|c|c|c|c|c|c|c|c|}
\hline \multirow{3}{*}{$\begin{array}{l}\text { LOOP } \\
\text { NO. }\end{array}$} & \multirow{3}{*}{$\begin{array}{l}\text { LENGTH } \\
\text { (MILES) }\end{array}$} & \multirow{3}{*}{$\begin{array}{l}\text { NO. OF } \\
\text { TEST- } \\
\text { SECTIONS }\end{array}$} & \multicolumn{11}{|c|}{ NUMBER OF TEST SECTIONS WITH } \\
\hline & & & TYPE OF & FACILITY & TYPE & $\mathrm{OF} P \mathrm{PF}$ & AUEliE & ENT & EST & IMA & TE & $\mathrm{OF}$ & PSR \\
\hline & & & THO-LAIIE & MULT ILAME & FLEX & OLAY & $J R C$ & CRC & 1 & 5 & 3 & 4 & 5 \\
\hline 1 & 194 & 20 & 9 & 11 & 4 & 4 & 8 & 4 & 5 & 1 & 7 & 6 & 4 \\
\hline 2 & 162 & 20 & 14 & 6 & 11 & 4 & 1 & 4 & 1 & 5 & 9 & 4 & 1 \\
\hline 3 & 154 & 20 & 11 & 9 & 5 & 9 & 2 & 4 & 0 & 5 & 5 & 7 & 3 \\
\hline 4 & 142 & 14 & 5 & 9 & 4 & 4 & 6 & 0 & 0 & 4 & 7 & 3 & 0 \\
\hline 5 & 160 & 20 & 17 & 3 & 13 & 5 & 2 & 0 & 4 & 5 & 6 & 5 & 0 \\
\hline
\end{tabular}




\section{CHAPTER 4: PAVEMENT SERVICEABILITY STUDIES}

\section{Introduction}

The purpose of this phase was to establish a procedure to objectively determine the present serviceability of pavements using the roadmeter instead of the subjective procedure presently used by the Indiana State Highway Commission.

A11 94 test sections described in Chapter 3 were used in this phase. A team of 20 raters rated all of the test sections independently and measurements of pavement roughnesses were made using the roadmeter during the same general period. Other factors which could possibly have affected the pavement serviceability ratings (PSR) were also measured. Some of these factors were selected on the bas is of remarks made by the raters, some on the basis of AASHO Road Test findings (16), and the rest as conceived by the researchers of this project. A number of extraneous variables not included in the AASHO Road Test were found to be significant and may be of interest to planners and designers of highways in the future.

Present Serviceability Index (PSI) models relating average PSR's with the roadmeter measurements and other factors were developed for each pavement type. These models, called Full Models, have high multiple correlation coefficients $\left(R^{2}\right)$ and relatively low standard errors (MSE). 
Since it may not always be practical for state highway departments to measure pavement surface properties, Reduced Models relating average PSR to roadmeter output only have also been developed. These Reduced Models are not very accurate but will be useful for estimating PSR within practical limits of accuracy required in maintenance planning.

PSI models developed in this chapter will doubtlessiy need to be revised after a certain period of time due to changes in the mechanical components of the roadmeter or due to changes in the expectations, attitudes, priorities etc., of road users. A procedure for periodically checking and revising these models has been detailed.

\section{Present Serviceability Ratings \\ Selection of Rating Panel}

Various studies $(23,31,44)$ of pavement serviceability have commented on the composition and size of panels for rating pavements which was initiated with the AASHO Road Test. These studies used 30-35 raters and found that the composition of the rating team should reflect the cross-section of the population of road users. Considering the recommendation of these studies and the scope and other practical limitations of this study, a 20 person team was organized to rate the pavement sections. Efforts were made to include members of both sexes and all age groups. Car size ranged from small to large and the age of car ranged from 1 year to 15 years. Details of the raters are given in Table D1 of Appendix D. 


\section{Rating Procedure}

The 94 test sections were organized into 5 loops each 150-200 miles long (Appendix $\mathrm{C}$ ). Each rater was requested to travel alone in his car around these 5 loops on 5 different days, in accordance with specific directions contained in a packet of materials assembled for each rater.

Rating Material. The following material was contained in each packet given to each rater.

1. Directions for Rating

2. Rating cards, arranged in five 4 " $\times 6$ " booklets, one for each 10op. A rating card and a title page of each booklet are given in Figures 10 and 11.

3. Five travel loop maps and location reference sheets (Appendix C).

4. Highway map of Indiana.

Instructions for Rating. The guiding principle in instructing the raters was to permit obtaining unbiased opinions of average individuals relative to the serviceability of pavements. A uniform set of instructions to each rater was considered vital to achieve this goal. The purpose of the study was briefly explained to each rater and was according to standard procedures used by others.

Rating Schedule. All pavements were rated during October and early November of 1977. A day was divided into two periods, morning and afternoon to account for any effects due to time of day, and each rater was required to rate a particular loop according to a schedule of randomized periods contained in the packet of rating material. For the 


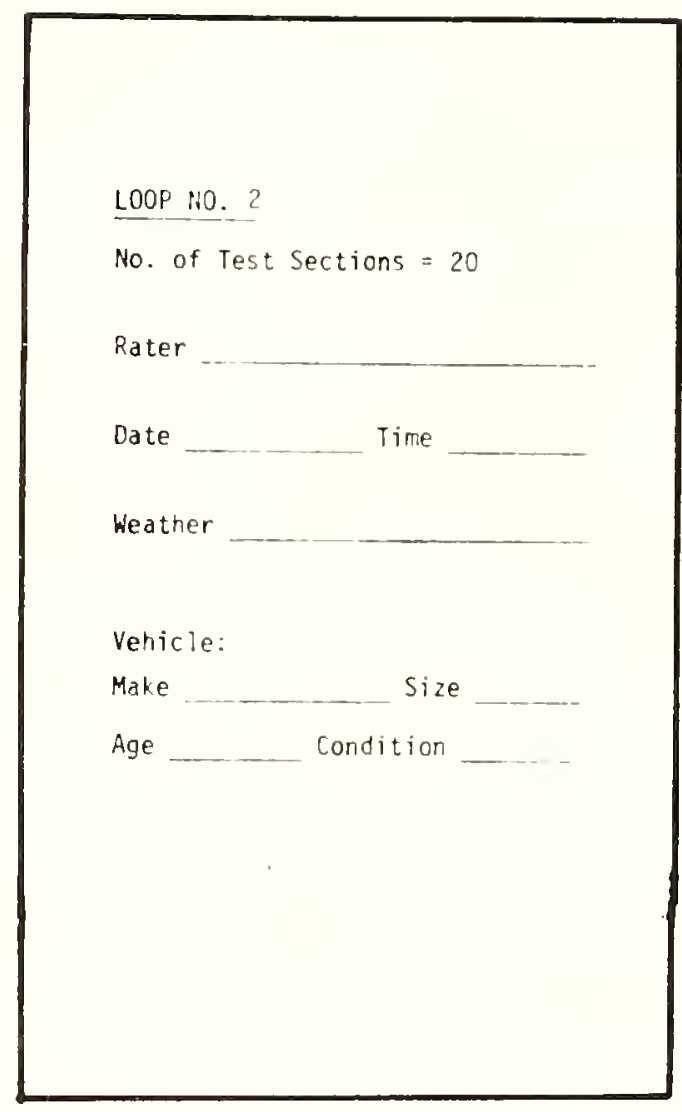

Figure 10: Title Page of a Rater's Book

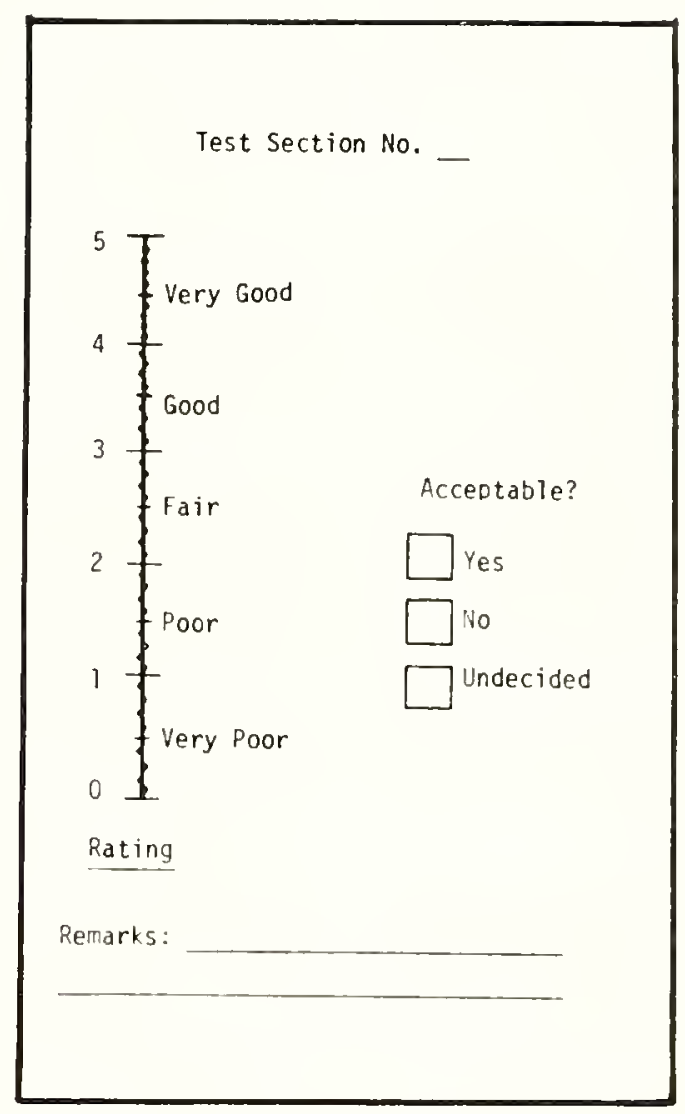

Figure 11: Rating Card 
same reason, the loop order was also randomized and each rater had to rate loops in the order specified in their packet.

\section{Acceptability Levels of Various Pavement Types}

After rating the test section by marking the scale from 0 to 5 , each rater was required to indicate the level of acceptability by marking one of the three boxes on the rating card, as below:
1. Yes
- (pavement acceptable)
2. No
- (pavement not acceptable)
3. Undecided - (not sure)

Remarks by the raters for each test section were not required and no guidelines or criteria were spelled out to the raters to avoid any restriction of their opinions since the remarks were meant only as a supplement to help determine the rater's true expectations relative to pavement rideability. The raters' remarks on the acceptability of all test sections are summarized in Table D2 of Appendix D. In this table the percent acceptability of pavements was calculated from the following:

Percent Acceptability $=\frac{\left(\begin{array}{c}\text { Number of } \\ \text { Yes Ratings }\end{array}\right)+.5\left(\begin{array}{c}\text { Number of } \\ \text { Undecided Ratings }\end{array}\right) \times 100}{\left(\begin{array}{c}\text { Number of } \\ \text { Raters }\end{array}\right)-\left(\begin{array}{c}\text { Number of } \\ \text { No Comment }\end{array}\right)}$

The percent of raters accepting a pavement having a particular mean PSR is shown in Figures 12 to 17 . Since the percent acceptability of a particular mean PSR was apparently different for each pavement type and also since the roadmeter output and mean PSR relation is a function of pavement type, separate graphs have been developed for each pavement type. Within each pavement type a separate relation has been 


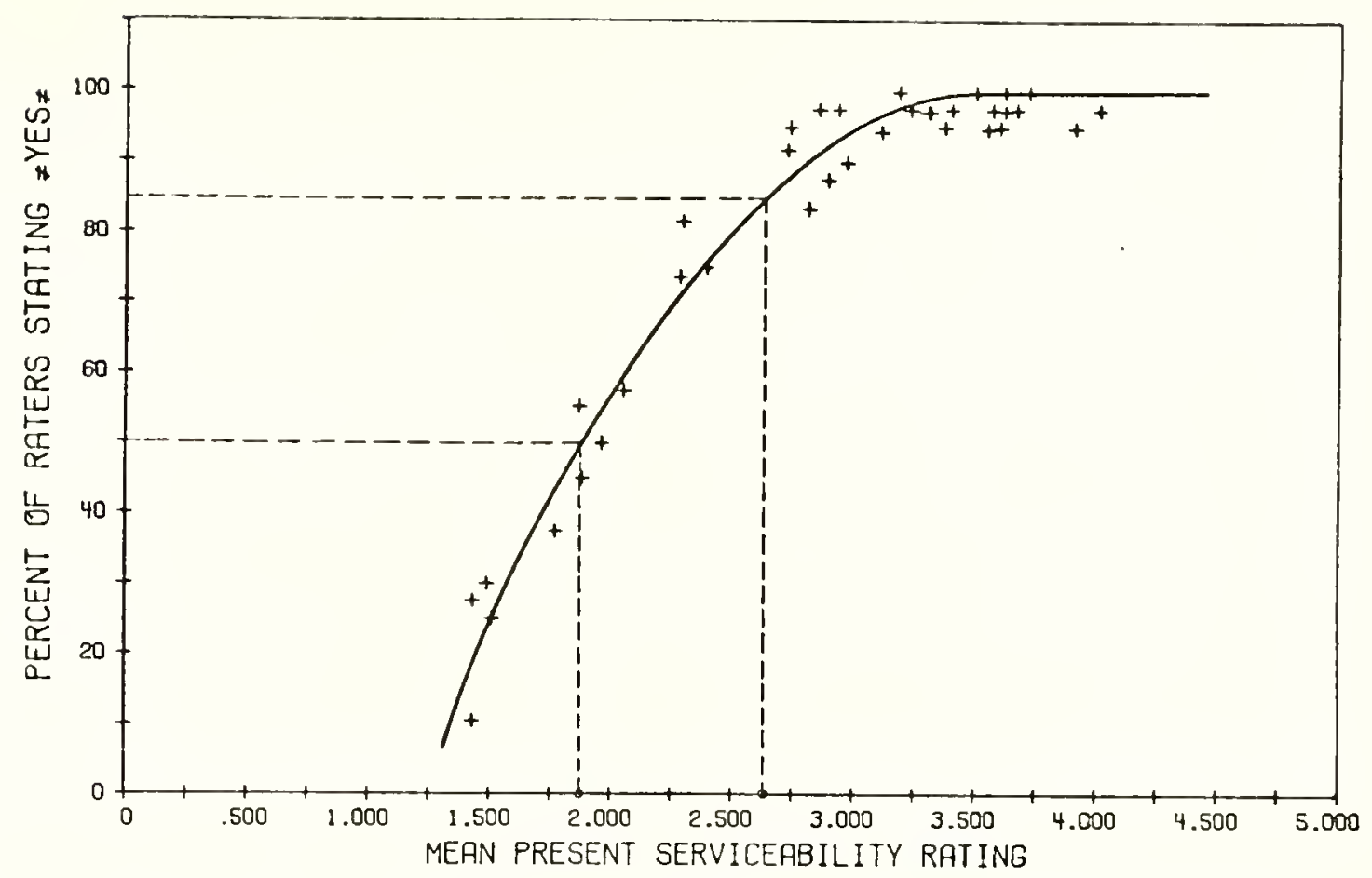

Figure 12: Social Acceptability Levels of Flexible Pavements on Two-Lane Facilities

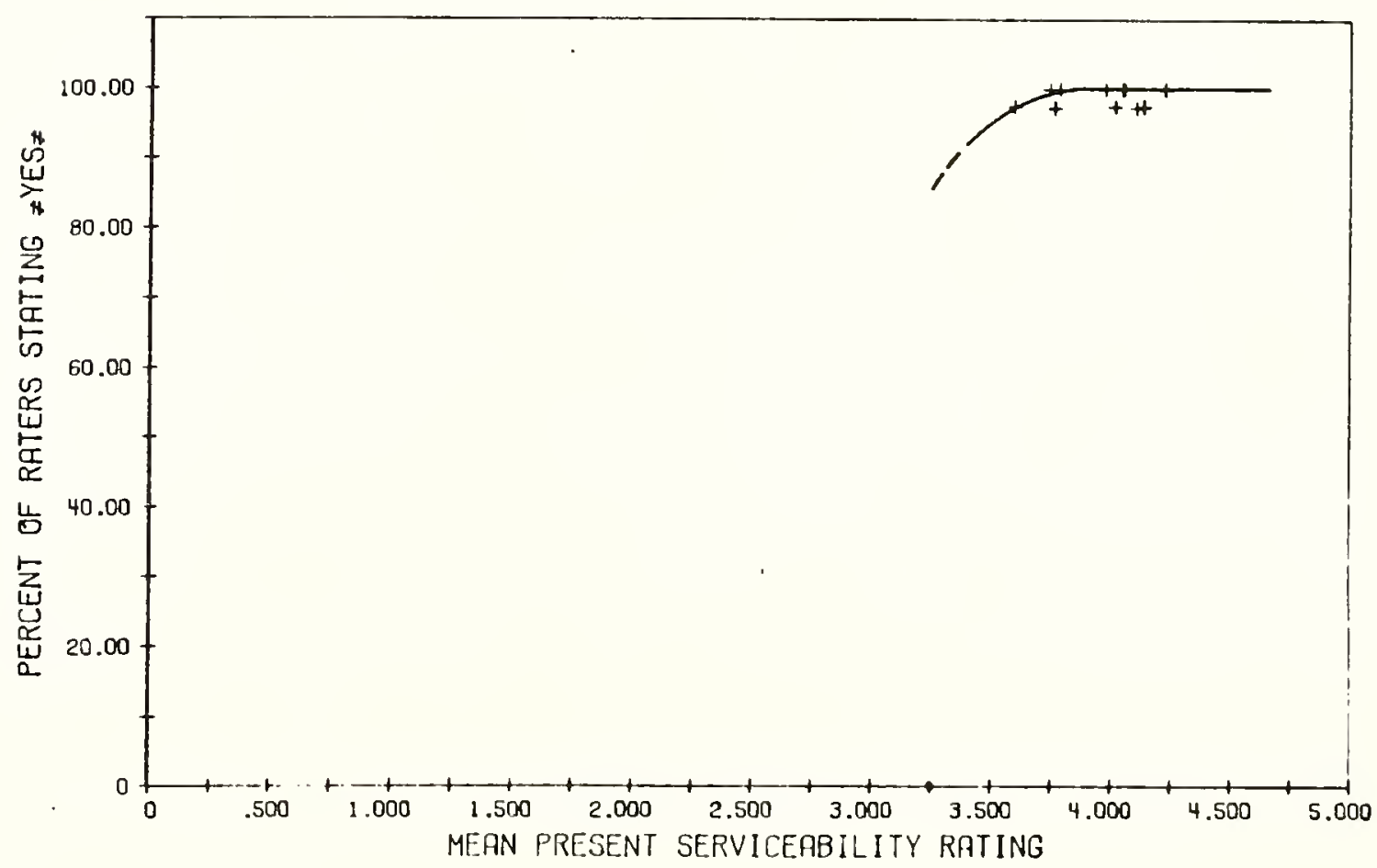

Figure 13: Social Acceptability Levels of CRC Pavements on Multilane Facilities 


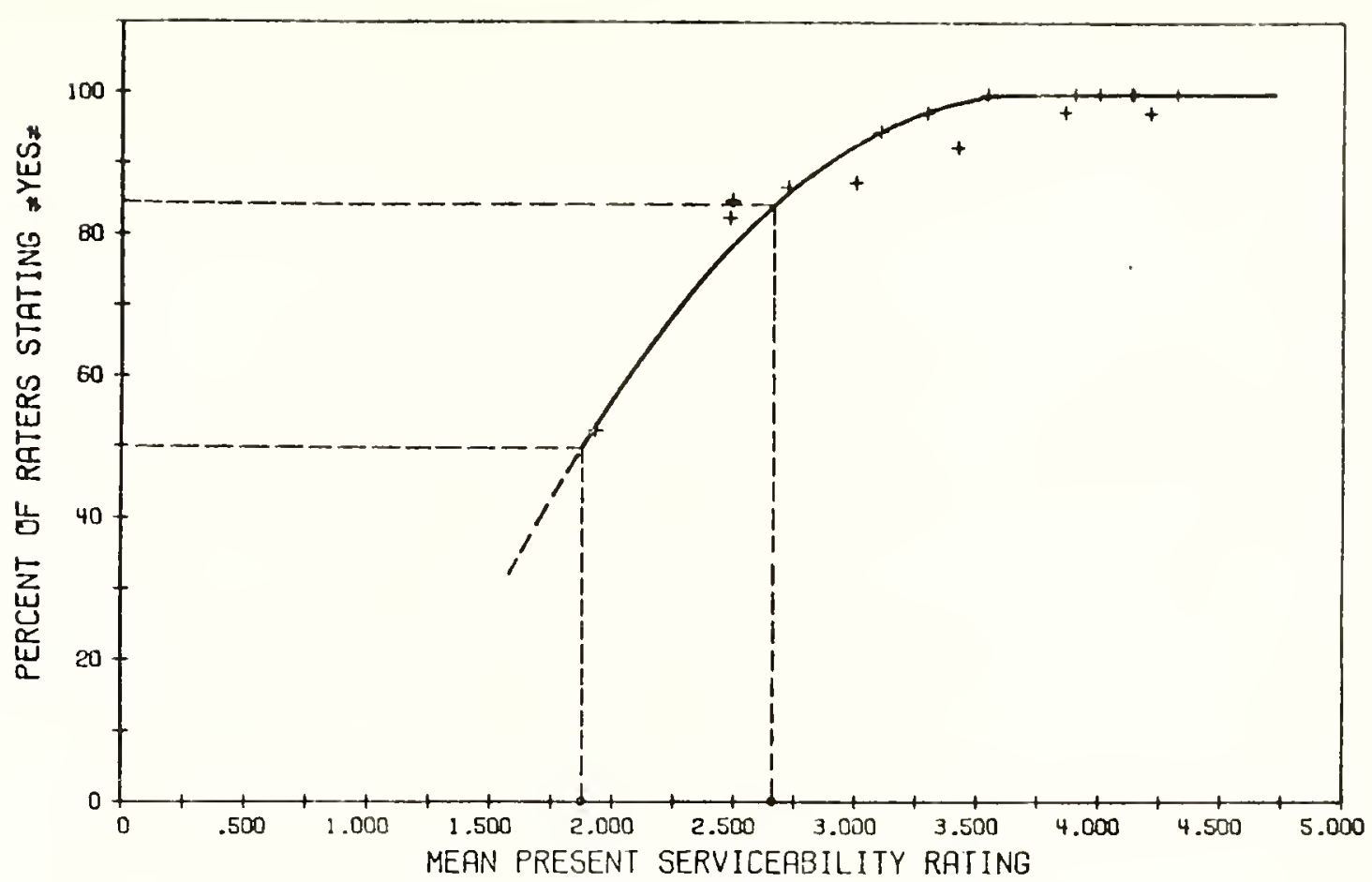

Figure 14: Social Acceptability Levels of Overlay Pavements on Two-Lane Facilities

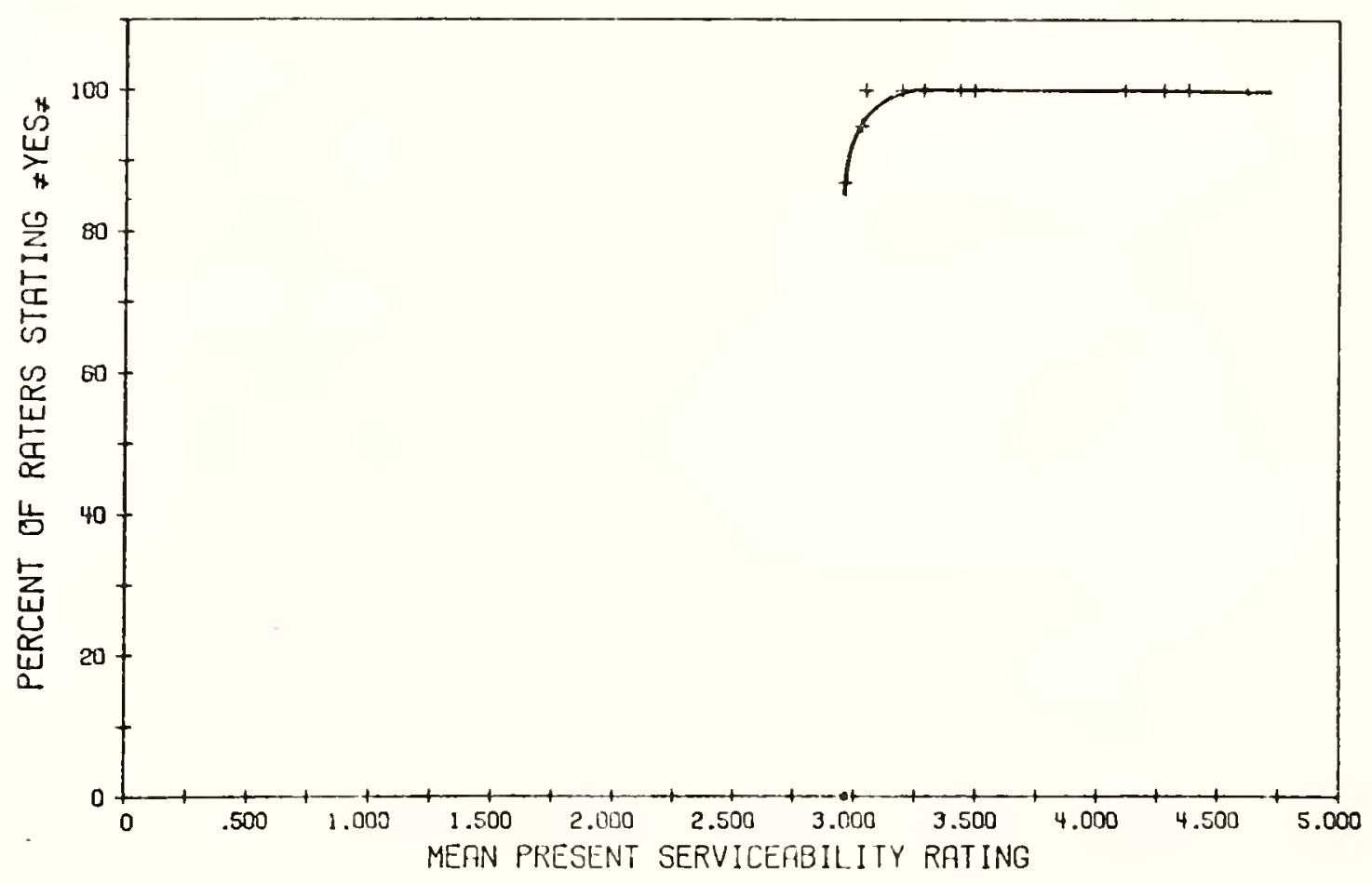

Figure 15: Social Acceptability Levels of Overlay Pavements on Multilane Facilities 


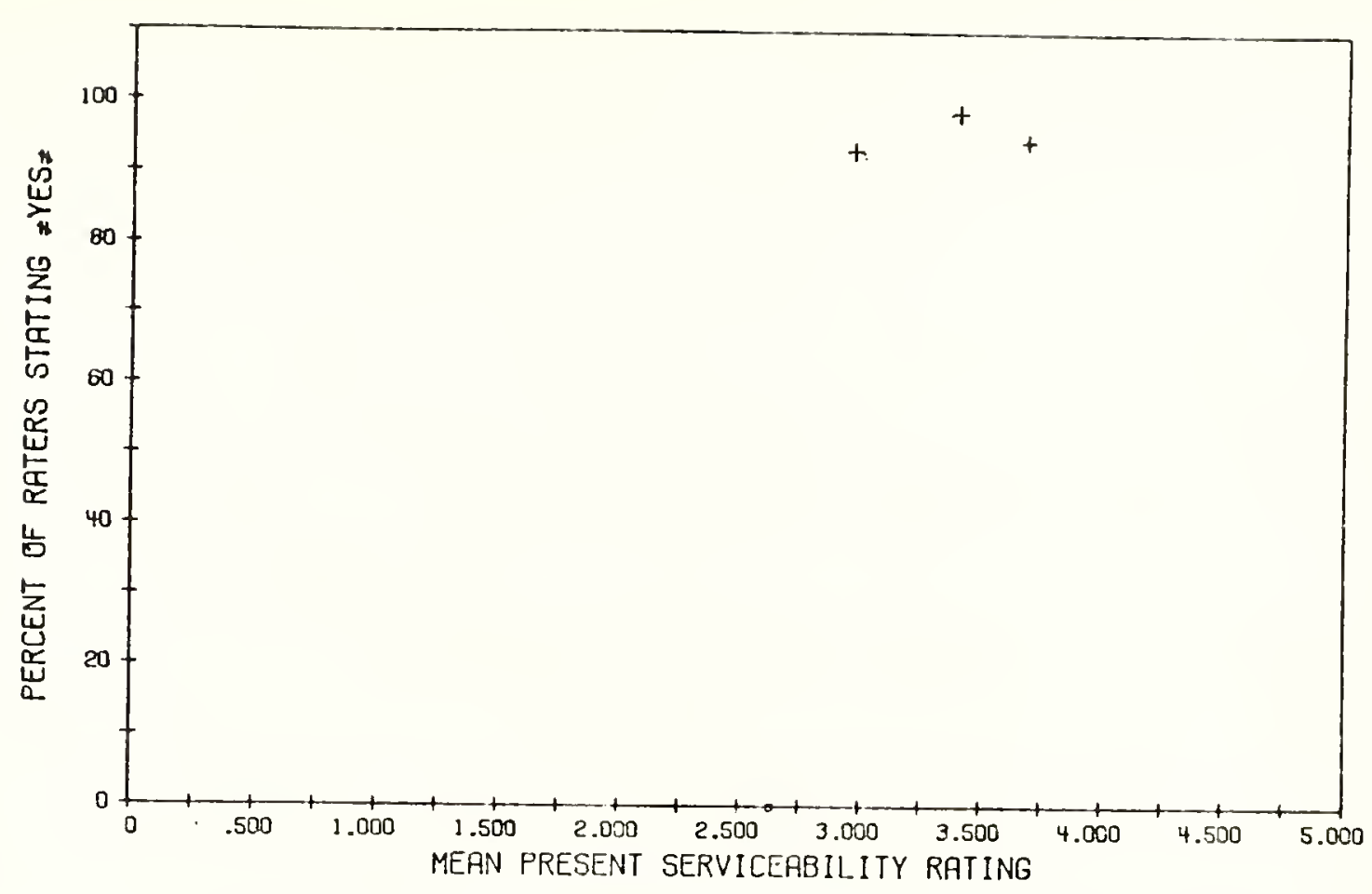

Figure 16: Social Acceptability Levels of JRC Pavements on Two-Lane Facilities

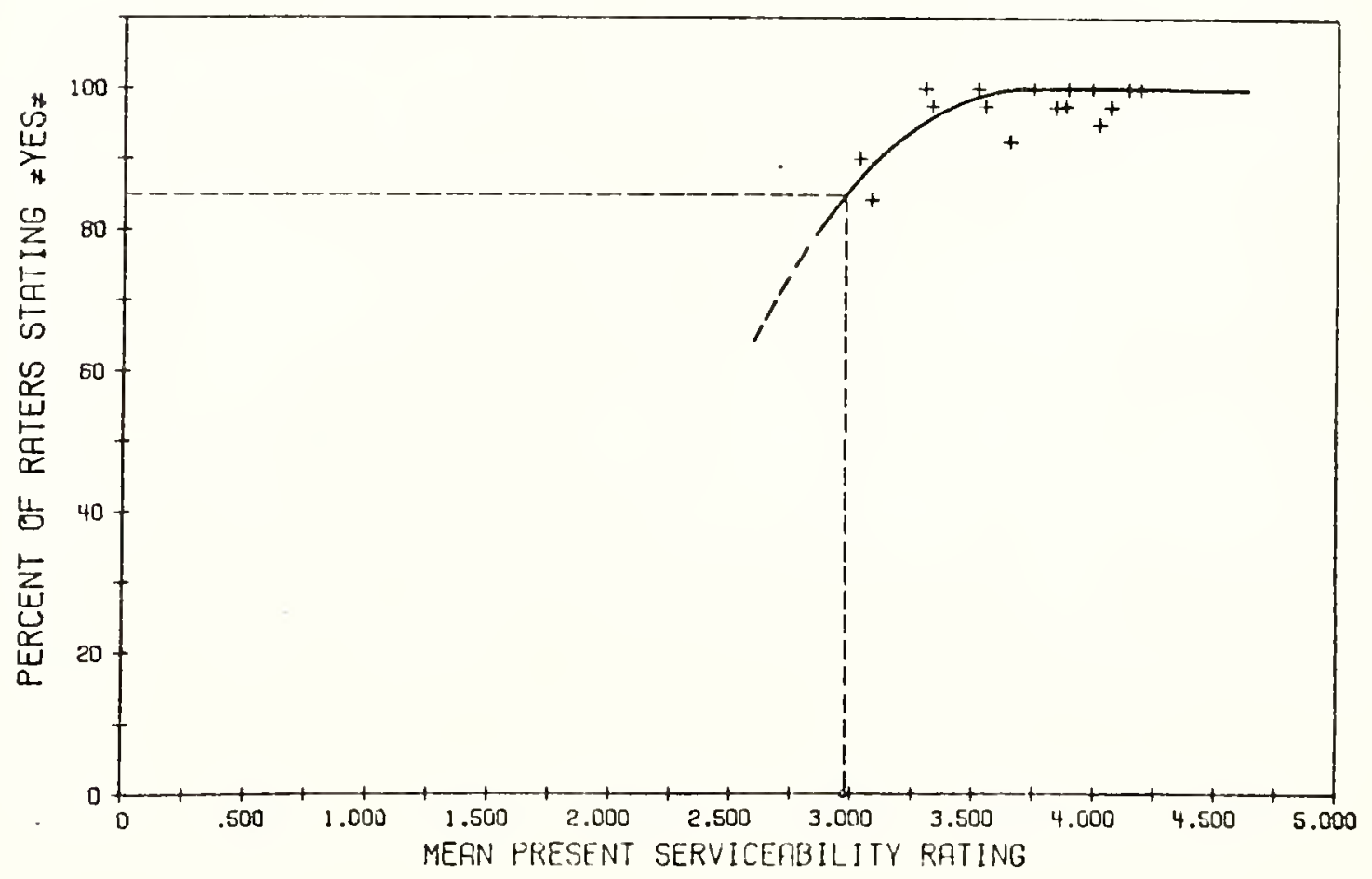

Figure 17: Social Acceptability Levels of JRC Pavements on Multilane Facilities 
graphed for each of the two facility types. Since only three observations were available for the two-lane JRC pavements, the points shown in Figure 16 have just fair reliability. PSR acceptability graphs for multilane flexible and two-lane CRC pavements could not be prepared since none of the flexible pavements included in this study were on multilane facilities and none of the CRC pavements were on two-lane facilities. The dotted portions of these graphs are extrapolations and therefore any conclusions based on these portions of the curves should be made with caution.

If the sample of raters of this study represent a true cross section of the population, which seems to be a valid assumption, the PSR acceptability levels based on these graphs should provide important information necessary for the planning of major maintenance of pavement systems. On the basis of these graphs, it can be seen that the travelling public desires to have a higher level of serviceability on multilane facilities as compared to the two-lane facilities. Eighty-five percent of road users desire to have a minimum PSR of about 3.0 on multilane facilities and about 2.7 on two-lane facilities. Fiftieth percentile values for multilane facilities cannot be read from these graphs because of lack of data in that range. However, for overlay and flexible pavements on two-lane facilities a minimum PSR of about 1.85 is desired by 50 percent of the road users.

\section{Recommended Size of a Rating Team}

While mechanical methods for measuring the serviceability of pavements are preferred for the rapid evaluation of pavements of considerable length, they may not provide consistent data since mechanical 
parts wear out with time and gradually lose their accuracy. Also, since personal attitudes, values etc., change, a machine calibrated against the subjective opinions of people at some point in time will probably be different after a lapse of time. Consequently, a machine, such as the roadmeter used in this study, will need to be recalibrated periodically against the opinions of raters selected from the population of road users.

The optimal size of a rating team for such recalibration is an important consideration. Too large of a team means unnecessary costs while a poor calibration is probabie if a team which is too small is chosen.

A rating panel may also be required for studies other than the recalibration of the roadmeter.

In selecting the size of a rating team it is necessary to ensure that the mean of the PSR'S $(\mu)$, given by $N$ raters is as close as possible to the true PSR $\left(\mu_{0}\right)$ of the pavement. In this situation the hypothesis to be tested will be of the following form:

$$
\begin{aligned}
& H_{0}: \mu=\mu_{0} \\
& H_{1}: \mu \neq \mu_{0}
\end{aligned}
$$

where: $\mu=$ mean of PSR's given by $N$ no. of raters

$$
\mu_{0}=\text { true PSR of the pavement. }
$$

This test will involve a 2-tailed t-test and with desired controls over $\alpha$ and $\beta$ errors, the number of raters will be given by (8)

$$
N=\left[\frac{\left(t_{\alpha}+t_{\beta}\right) \sigma}{c}\right]^{2}
$$


where: $N=$ size of rating team

$$
\begin{aligned}
& \alpha=\text { probability of Type I error } \\
& \beta=\text { probability of Type II error } \\
& \sigma=\text { an estimate of standard deviation between raters } \\
& C=\text { acceptable error }
\end{aligned}
$$

In this study a standard deviation of 0.6179 was found between

raters. For this estimate of $\sigma$, various combinations of $\alpha$ and $\beta$ errors and acceptable errors of 0.1 to 1.0 , the number of raters required is

\begin{tabular}{|c|c|c|c|c|c|c|c|c|c|c|c|c|c|}
\hline \multirow{2}{*}{$\begin{array}{l}\text { ACCEPTABLE } \\
\text { ERROR (PSR) }\end{array}$} & \multirow{2}{*}{$\begin{array}{l}\alpha \\
\beta\end{array}$} & \multicolumn{4}{|c|}{-.05} & \multicolumn{4}{|c|}{1} & \multicolumn{4}{|c|}{.2} \\
\hline & &.$\overline{05}$ & .1 &.$\overline{2}$ & .5 & .05 & .1 & .2 & .5 & .05 & .1 & .2 & .5 \\
\hline .1 & & 558 & 447 & 334 & 158 & 457 & 357 & 257 & 115 & 357 & 270 & 183 & 68 \\
\hline .2 & & 140 & 112 & 84 & 42 & 115 & 90 & 64 & 29 & 90 & 68 & 46 & 17 \\
\hline .3 & & 62 & 50 & 37 & 19 & 51 & 40 & 29 & 13 & 40 & 30 & 21 & 8 \\
\hline .4 & & 35 & 28 & 21 & 11 & 29 & 23 & 16 & 8 & 23 & 17 & 12 & 5 \\
\hline .5 & & 23 & 18 & 14 & 7 & 19 & 15 & 11 & 5 & 15 & 11 & 8 & 3 \\
\hline .6 & & 16 & 13 & 10 & 5 & 13 & 10 & 8 & 4 & 10 & 8 & 5 & 2 \\
\hline .7 & & 12 & 10 & 7 & 4 & 10 & 8 & 6 & 3 & 8 & 6 & 4 & 2 \\
\hline .8 & & 9 & 7 & B & 3 & 8 & 6 & 4 & 2 & 6 & 5 & 3 & 1 \\
\hline .9 & & 7 & 6 & 5 & 2 & 6 & 5 & 4 & 2 & 5 & 4 & 3 & 1 \\
\hline 1.0 & & 6 & 5 & 4 & 2 & 5 & 4 & 3 & 2 & 4 & 3 & 2 & 1 \\
\hline
\end{tabular}
given in Table 15.

Table 15: NUMBER OF RATERS REQUIRED TO ESTIMATE PRESENT SERUICEABILITY RATING OF PAUEMENTS

Note: Portions of the table within boxes are the ranges of various variables, recommended for use. A lower value of acceptable error is recommended for the purpose of recalibration of the roadmeter. 
Choice of $\alpha$ and $\beta$ Errors. A judicious choice of $\alpha$ and $\beta$ errors will be dependent on the purpose of pavement ratings and the accuracy desired. This decision should be taken by the concerned authority and no precise rules can be given in this research. The following guidelines are, however, proposed in making choice of $\alpha$ and $\beta$ errors.

$\begin{array}{lll} & \underline{\alpha} & \frac{\beta}{} \\ \text { For High Accuracy } & .05 & .20 \\ \text { For Medium Accuracy } & .05 & .50 \\ \text { For Low Accuracy } & .10 & .50\end{array}$

For the above $\alpha$ and $\beta$ errors and for acceptable errors of 0.3 to 0.6 , the number of raters required are shown as boxed in Table 15.

Measurement of Factors Affecting Pavement Serviceability

Measurement of Roughness Using Roadmeter

Roadmeter tests on all 94 test sections were run during the months of October 1977 to December 1977. Three of the five loops were measured twice while two were measured three times. The loop order was randomized and the standard conditions for roadmeter operation as laid out in Appendix B, were followed. Air temperature and gas tank levels were recorded at intervals. Logarithms of the roadmeter measurements were adjusted for the effects of air temperatures and gas tank levels and these normalized measurements were used in building Present Serviceability Index (PSI) models.

Measurement of Surface Properties

The following three items which describe the condition of a pavement were measured: 


\section{Rut Depth \\ 2. Cracking \\ 3. Patching}

A11 measurements were made in the outer lane in the case of highway sections having 4 or more lanes. For these three measurements and also for deflection measurements, a 400 meter long sub-section was randomly sampled from each $1 \mathrm{~km}$. long test section and assuming that this sub-section was a true representative of the whole test-section, the above measurements were made in the sub-section only. For reference and recording, each 400 meter long sub-section was divided into 20 divisions and reference lines were marked at 20 meter intervals, as shown in Figure 18.

Rut Depth Measurements. Rut depths in both wheel paths of all flexible pavements were measured during the fall of 1977 when all other measurements defining pavement surface were also taken. Ten rut depth measurements were recorded in each whee 1 path within a 400 meter long sub-section.

A manual rut depth gage, similar to the one used in AASHO road test, was made and used for rut depth measurements. The rut depth gage is shown in Figure 19. The gage was held vertically across the wheel path and moved laterally along the reference line a foot or two either way to read the maximum rut depth. Each rut depth was read in $1 / 16$ inch units.

The two wheel paths were designated as outer wheel path (OWP) and inner wheel path (IWP), and the rut depth of a test section in each wheel path of each test section was calculated as the simple average of the ten readings. 


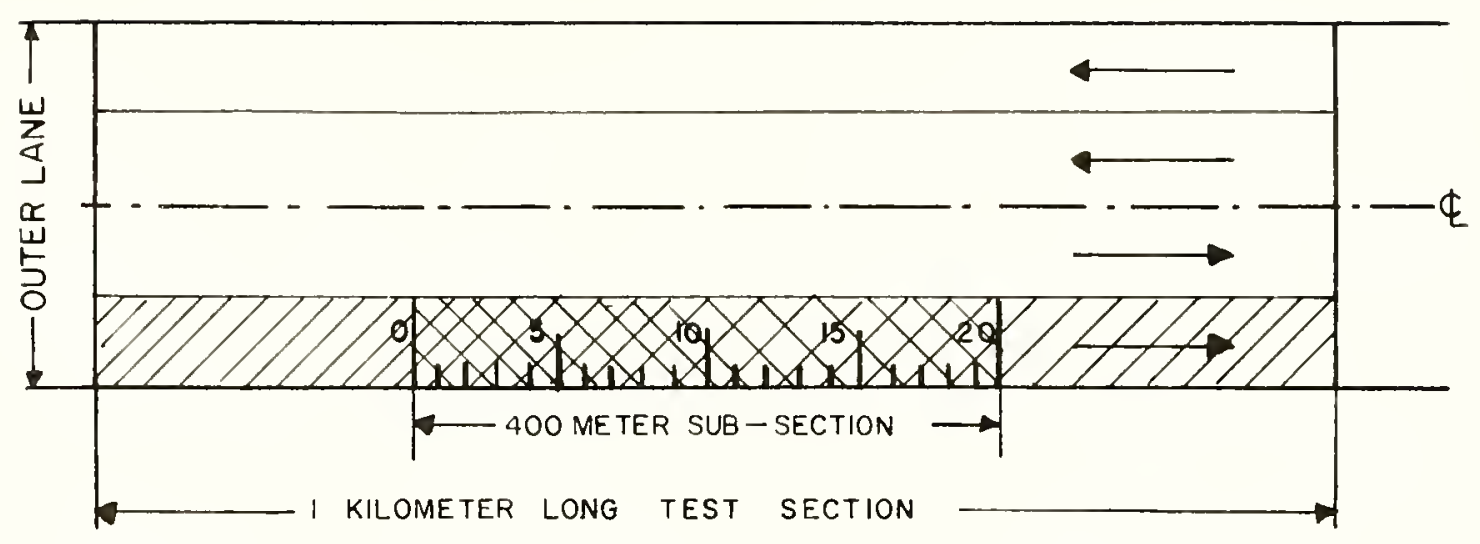

Figure 18: Typical Layout of Test Sections 

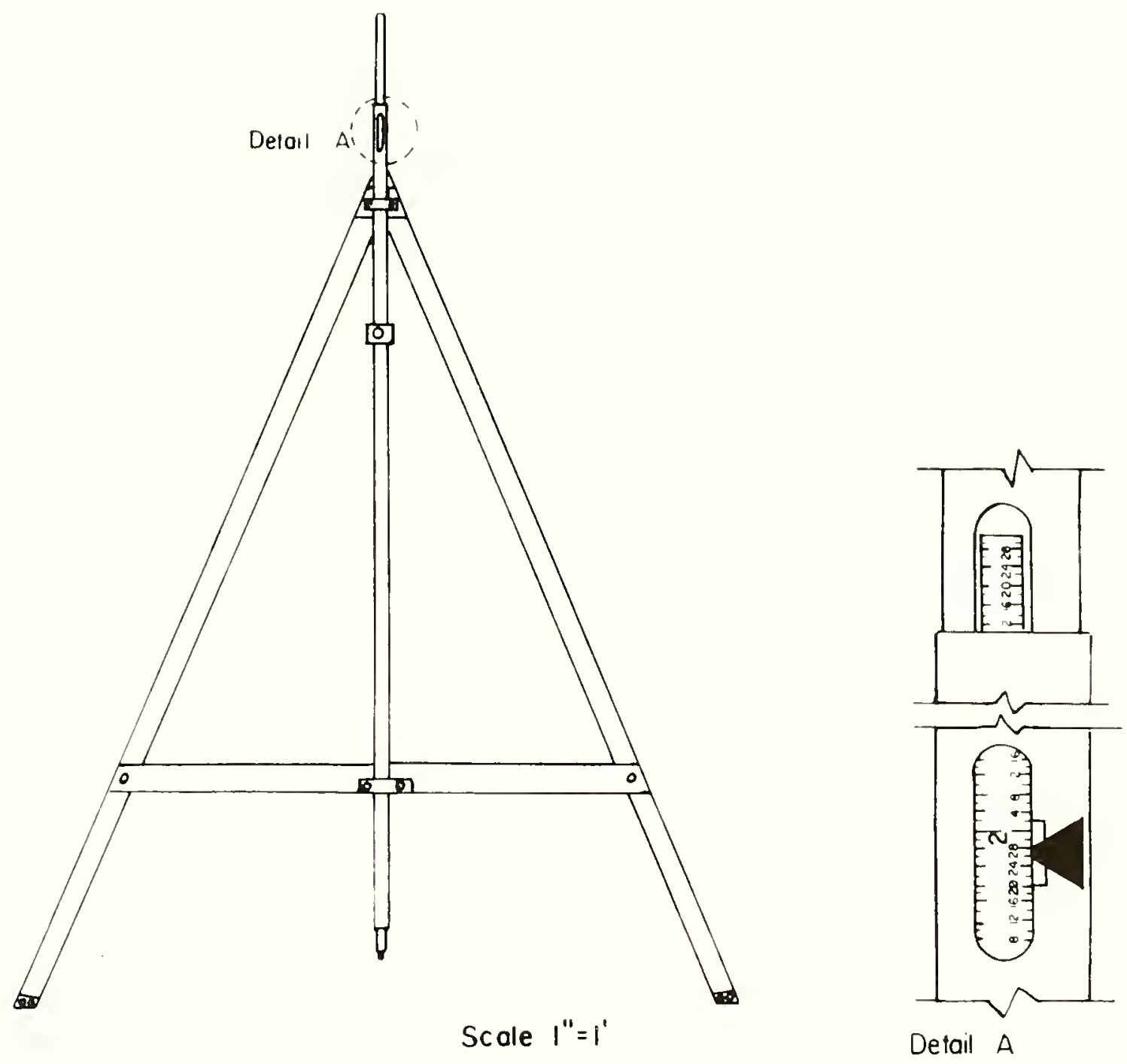

Figure 19: Rut Depth Gage 
Measurements of Cracking. Crack measurements were made during the fall of 1977. AASHO definitions for various classes of cracking were foll lowed.

Overlay pavements which were overlaid in the recent past had a cracking pattern like flexible pavements. In these cases the transverse joints had not opened enough to be felt in a moving vehicle. On the other hand some overlay pavements had transverse joints which were wide open and rough and very apparently had a cracking pattern similar to JRC pavements. An open joint effects the roadmeter output and the serviceability ratings but cannot be put in any class of flexible pavement cracks, while alligator cracking which undoubtedly makes an impact on the surface roughness is not measurable according to the AASHO definition of cracks for rigid pavements. To provide a complete evaluation, the cracks of overlay pavements were measured twice; once according to the definition of flexible pavements and then in accordance with the definition for rigid pavement cracks.

Measurements of Patching. Patched areas in each sub-section were measured along with the measurements of cracks and recorded on the same form.

Measurement of Extraneous Characteristics

The AASHO Road Test has established that the three major factors which affect the PSR of a pavement, in addition to the output of roughness measuring device, are cracking, patching and rut depth (in the case of flexible pavements only). In this research, it was proposed to examine some additional variables related with the geometry and environment of a highway for their possible effect on the PSR. The following variables were examined: 
1. Type of Facility

2. Effective Width of Travel Lane

3. Type of Terrain

4. Environment

5. Sight Distance

6. Horizontal Alignment

Except for the effective width of travel lane which was treated as a quantitative variable, all other variables were measured and analyzed as qualitative variables. The following criteria were used in measuring each of these variables:

1. Type of Facility: The highways were broken down into two categories:
(i) Multilane facilities
(ii) Two-lane facilities

A highway having four or more lanes in both directions was defined as a multilane facility and a highway with 2 lanes in both directions was defined as a two-lane facility. With this criteria, all the flexible pavements included in this research fell in the two-lane category and all CRC pavements in the multilane category. Therefore, the effect of this factor on these two pavement types could not be examined.

2. Effective Width of Travel Lane: Many of the raters remarked that some pavements were narrow. This factor was therefore included to examine if narrow widths had influenced the serviceability ratings of pavements. Since the effects of shoulder and lane width are largely interrelated, a combined effect of the two was considered. A term 'effective width of travel lane (or effecitve width)' was defined as below: 


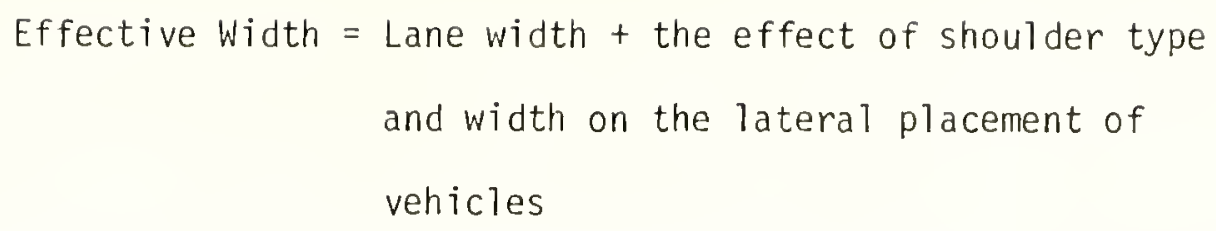

The Highway Capacity Manual (17) has observed that for lanes less than $12 \mathrm{ft}$. wide, paved shoulders $4 \mathrm{ft}$. or wider increase the effective width of adjacent traffic lane by $1 \mathrm{ft}$.

Shelby and Tutt (35) found that shoulder widths of $3 \mathrm{ft}$. or more did not effect lateral placement of vehicles but the type of shoulders had a definite effect. The above study also observed that as the lane width is increased the vehicles move out 3 inches for each foot added to the lane. Shelby and Tutt have tabulated the placement distances of passenger cars from the outer edge of lane for earth, gravel and paved shoulders and also for various widths of gravel and paved shoulders. On the basis of these studies, decision rules to determine the effect of shoulder on the effective width were made as given in Table 16.

\section{Table 16: Effect of Shoulder width and Type on Effective Width of Pavements}

\begin{tabular}{ccc}
\hline SHOULDER TYPE & WIDTH & EFFECT ON EFFECTIUE WIDTH \\
\hline PAUED & $24 \mathrm{FT}$ & $+1 \mathrm{FT}$ \\
PAUED & $<4 \mathrm{FT}$ & $0 \mathrm{FT}$ \\
GRAUEL & $24 \mathrm{FT}$ & $0 \mathrm{FT}$ \\
GRAUEL & $<4 \mathrm{FT}$ & $-1 \mathrm{FT}$ \\
EARTH & $24 \mathrm{FT}$ & $-1 \mathrm{FT}$ \\
EARTH & $<4 \mathrm{FT}$ & $-2 \mathrm{FT}$ \\
\hline
\end{tabular}

Wherever the shoulder width was of more than one type, the following width equivalencies were used to convert all widths to one type before calculating the effective width:

$$
4 \mathrm{ft} \text { Earth }=2 \mathrm{ft} \text { Gravel }=1 \mathrm{ft} \text { Paved }
$$


3. Type of Terrain: The terrain of each test section was classified into one of the three following categories:
(i) Hilly
(ii) Rolling
(iii) Flat

One man subjectively recorded the terrain type along with other measurements. None of the 94 test sections fell in the hilly category.

4. Environment: Environment, in this research, was divided into one of the following two categories:

(i) Open

(ii) STightly restricted

Test sections which were surrounded by village houses, farm fencing and any other structure so as to give a restricted feeling to the driver were put in the 'slightly restricted' category.

5. Sight Distance: This factor was broken into three categories, and measured subjectively by one man as follows:
(i) Poor
(ii) Fair
(iii) Good

6. Horizontal Alignment: This factor was measured by the following three classes:
(i) Poor
(ii) Fair
(iii) Good

Again, one man subjectively determined which one of the above three levels of this factor best described the existing roadway situation. 
Values of all variables for each of the 94 test sections as used to build PSI models are given in Tables D3 to 07 of Appendix D.

\section{Present Serviceability Index Models}

The purpose of this phase of the study was to develop regression equations which could be used to estimate the PSI of pavement sections when values of influencing variables are known. The following independnet variables were used to develop the required models:

Independent Variable

1. Adjusted $\log _{10}$ (Roadmeter Counts/Kilometer)

2. Cracking Class 1

3. Cracking Class 2

4. Cracking Class 3

5. Cracking Class 4 *

6. Patching

7. Rut depth, outer wheel path**

8. Rut depth, inner wheel path**

9. Type of Facjlity

10. Effective width of travel lane

11. Type of Terrain

12. Environment

13. Sight Distance

14. Horizontal Alignment

\section{Symbol}

$\log _{10} x$

C1

C2

C3

C4

P

RD1

RD2

F

$W$

T

E

SD

A

Variable nos. 9, 11, 12, 13 and 14 were used as qualitative variables and the rest as quantitative variables.

* For rigid pavements only.

**For flexible pavements only. 
Development of Models

Preliminary analyses and scattergrams revealed the following:

(a) $\log X$ was best related to mean PSR.

(b) Each pavement type produced a different relationship between $\log X$ and mean PSR.

(c) Except in the case of JRC pavements, the relationship between $\log X$ and mean PSR was not linear. Consequently, it was decided to develop separate models for each pavement type. Regression programs available at the Purdue University Computing Center were used for analyzing data. Stepwise regression procedure was applied on all first degree terms, second degree terms and two factor interactions. The following $F$ values were used to enter and remove variables at each step of the regression procedure (24):

$$
\begin{aligned}
\text { FIN } & =F(.1 ; 1, n-p-1) \\
\text { FOUT } & =F(.25 ; 1, n-p)
\end{aligned}
$$

where: $n=$ number of observations

$$
p=\text { number of independent variables }
$$

Criteria for Model Building. The various models developed in this research, relating mean PSR with the roadmeter output, surface cracking and patching, rut depth (in the case of flexible pavements) and other influencing factors will be used to estimate the PSI of road sections. Because estimation and not prediction or description will be the principal use, the models were developed with an eye toward minimizing the MSE. The following criteria were followed in building the models:

(a) A lower MSE of estimation. This criteria almost always gave higher multiple correlation coefficients $\left(R^{2}\right)$, which is a very desirable property. 
(b) The least possible number of variables were included in any model for ease in field measurements and computations, and only two degree terms and two factor interactions were examined for significance to make the effect of each independent variable on the response variable more understandable.

(c) Residual plots were examined at each stage and wherever necessary various transformations of variables in the equation were tried to get a good scatter of residuals. Sometimes the addition of more variables or interaction terms improved the scatter.

(d) A significance level of .05 was used. A factor significant upto a level of. I was considered for inclusion in the model under very special circumstances.

Forms of PSI Models. For each pavement type, two forms of models have been developed
(i) Full Models
(ii) Reduced Models

Reduced Models relate only the roadmeter output with mean PSR. These models are approximate but are easy to use and may be useful in maintenance planning where less accuracy is sometimes acceptable. These models are given in Equations 10,13,16 and 18; tabulated for convenience in their use (Table 17) and are also graphed as in Figures 20 to 23.

Ful1 models (Equations 11, 12, 14, 15, 17 and 19) are more accurate and include more variables. In the cases of flexible and overlay pavements, two models have been developed for each pavement type. 
Table 17: Determination of PSI Values from Roadmeter Output

\begin{tabular}{|c|c|c|c|c|c|c|}
\hline \multicolumn{2}{|c|}{$\begin{array}{l}\text { ADJUSTED } \\
\text { LOG (RM COUNTS } \\
\text { PER KILOMETER) }\end{array}$} & $\begin{array}{l}\quad \text { PSI } \\
\text { FLEXIBLE } \\
\text { PRUEMENTS }\end{array}$ & $\begin{array}{l}\quad \text { PSI } \\
\text { OUERLAY } \\
\text { PAUEMENTS }\end{array}$ & $\begin{array}{c}\text { PSI } \\
\text { JRC } \\
\text { PAUEMENTS }\end{array}$ & $\begin{array}{c}\text { PSI } \\
\text { CRC } \\
\text { PRUEMENTS }\end{array}$ & $\begin{array}{l}\text { ADJUSTED } \\
\text { LOG(RM COUNTS } \\
\text { PER MILE) }\end{array}$ \\
\hline & 2.00 & & & 4.99 & 4.43 & 2.21 \\
\hline & 2.05 & & & 4.91 & 4.40 & 2.26 \\
\hline & 2.10 & & 4.92 & 4.84 & 4.37 & 2.31 \\
\hline & 2.15 & & 4.74 & 4.76 & 4.35 & 2.36 \\
\hline & 2.20 & & 4.57 & 4.68 & 4.32 & 2.41 \\
\hline & 2.25 & & 4.41 & 4.61 & 4.29 & 2.46 \\
\hline & 2.30 & & 4.26 & 4.53 & 4.26 & 2.51 \\
\hline & 2.35 & & 4.11 & 4.45 & 4.23 & 2.56 \\
\hline & 2.40 & & 3.97 & 4.37 & 4.20 & 2.61 \\
\hline & 2.45 & & 3.83 & 4.30 & 4.17 & 2.66 \\
\hline & 2.50 & 3.76 & 3.71 & 4.22 & 4.14 & 2.71 \\
\hline & 2.55 & 3.75 & 3.59 & 4.14 & 4.11 & 2.76 \\
\hline & 2.60 & 3.74 & 3.48 & 4.07 & 4.07 & 2.81 \\
\hline & 2.65 & 3.72 & 3.37 & 3.99 & 4.04 & 2.86 \\
\hline & 2.70 & 3.69 & 3.27 & 3.91 & 4.01 & 2.91 \\
\hline & 2.75 & 3.65 & 3.18 & 3.84 & 3.97 & 2.96 \\
\hline & 2.80 & 3.60 & 3.10 & 3.76 & 3.94 & 3.01 \\
\hline & 2.85 & 3.53 & 3.02 & 3.68 & 3.90 & 3.06 \\
\hline & 2.90 & 3.46 & 2.95 & 3.61 & 3.86 & 3.11 \\
\hline & 2.95 & 3.38 & 2.89 & 3.53 & 3.83 & 3.16 \\
\hline & 3.00 & 3.29 & 2.84 & 3.45 & 3.79 & 3.21 \\
\hline & 3.05 & 3.18 & 2.79 & 3.37 & 3.75 & 3.26 \\
\hline & 3.10 & 3.07 & 2.75 & 3.30 & 3.71 & 3.31 \\
\hline & 3.15 & 2.95 & 2.71 & 3.22 & 3.67 & 3.36 \\
\hline & 3.20 & 2.81 & 2.69 & 3.14 & 3.63 & 3.41 \\
\hline & 3.25 & 2.67 & 2.67 & 3.07 & 3.59 & 3.46 \\
\hline & 3.30 & 2.51 & 2.66 & 2.99 & 3.55 & 3.51 \\
\hline & 3.35 & 2.35 & 2.65 & 2.91 & 3.51 & 3.56 \\
\hline & 3.40 & 2.17 & & 2.84 & 3.46 & 3.61 \\
\hline & 3.45 & 1.99 & & 2.76 & 3.42 & 3.66 \\
\hline & 3.50 & 1.79 & & 2.68 & 3.37 & 3.71 \\
\hline & 3.55 & 1.59 & & 2.61 & 3.33 & 3.76 \\
\hline & 3.60 & 1.37 & & 2.53 & 3.28 & 3.81 \\
\hline & 3.65 & 1.14 & & 2.45 & 3.24 & 3.86 \\
\hline & 3.70 & .91 & & 2.37 & 3.19 & 3.91 \\
\hline & 3.75 & .66 & & 2.30 & 3.14 & 3.96 \\
\hline & 3.80 & .40 & & 2.22 & 3.10 & 4.01 \\
\hline & 3.85 & .14 & & 2.14 & 3.05 & 4.06 \\
\hline & 3.90 & & & 2.07 & 3.00 & 4.11 \\
\hline & 3.95 & & & 1.99 & 2.95 & 4.16 \\
\hline & 4.00 & & & 1.91 & 2.90 & 4.21 \\
\hline
\end{tabular}




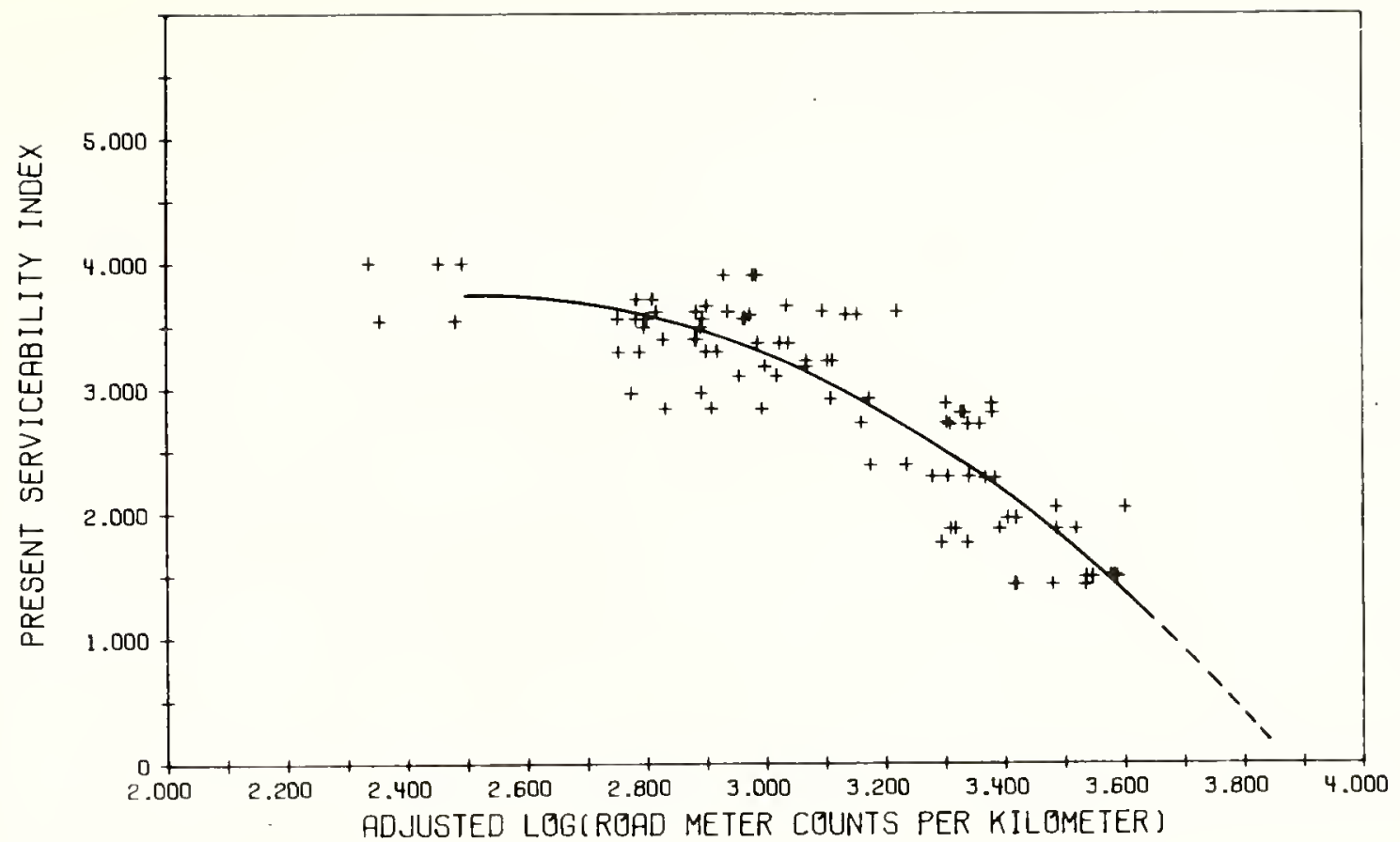

Figure 20: Roadmeter Calibration, Flexible Pavements

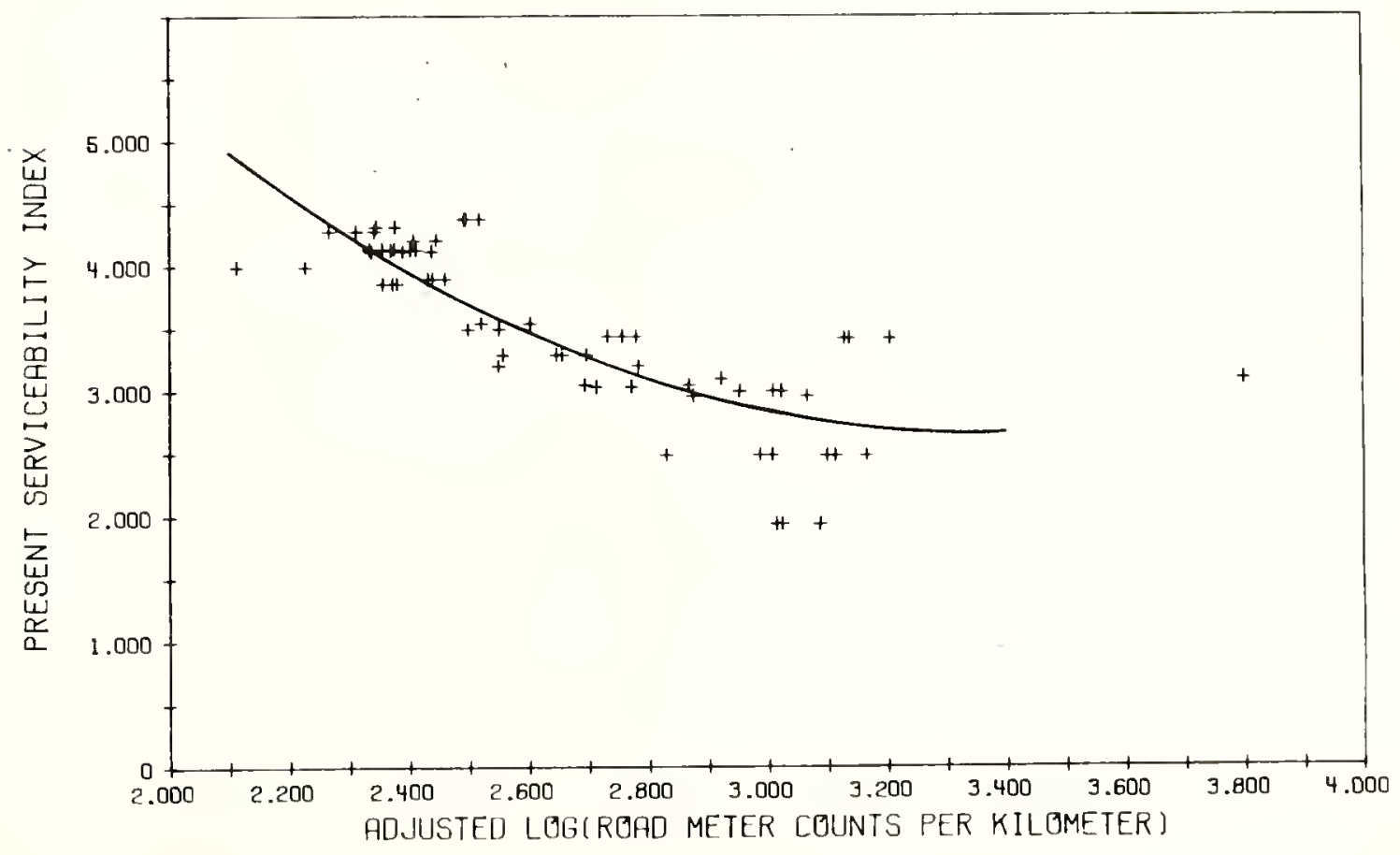

Figure 21: Roadmeter Calibration, Overlay Pavements 


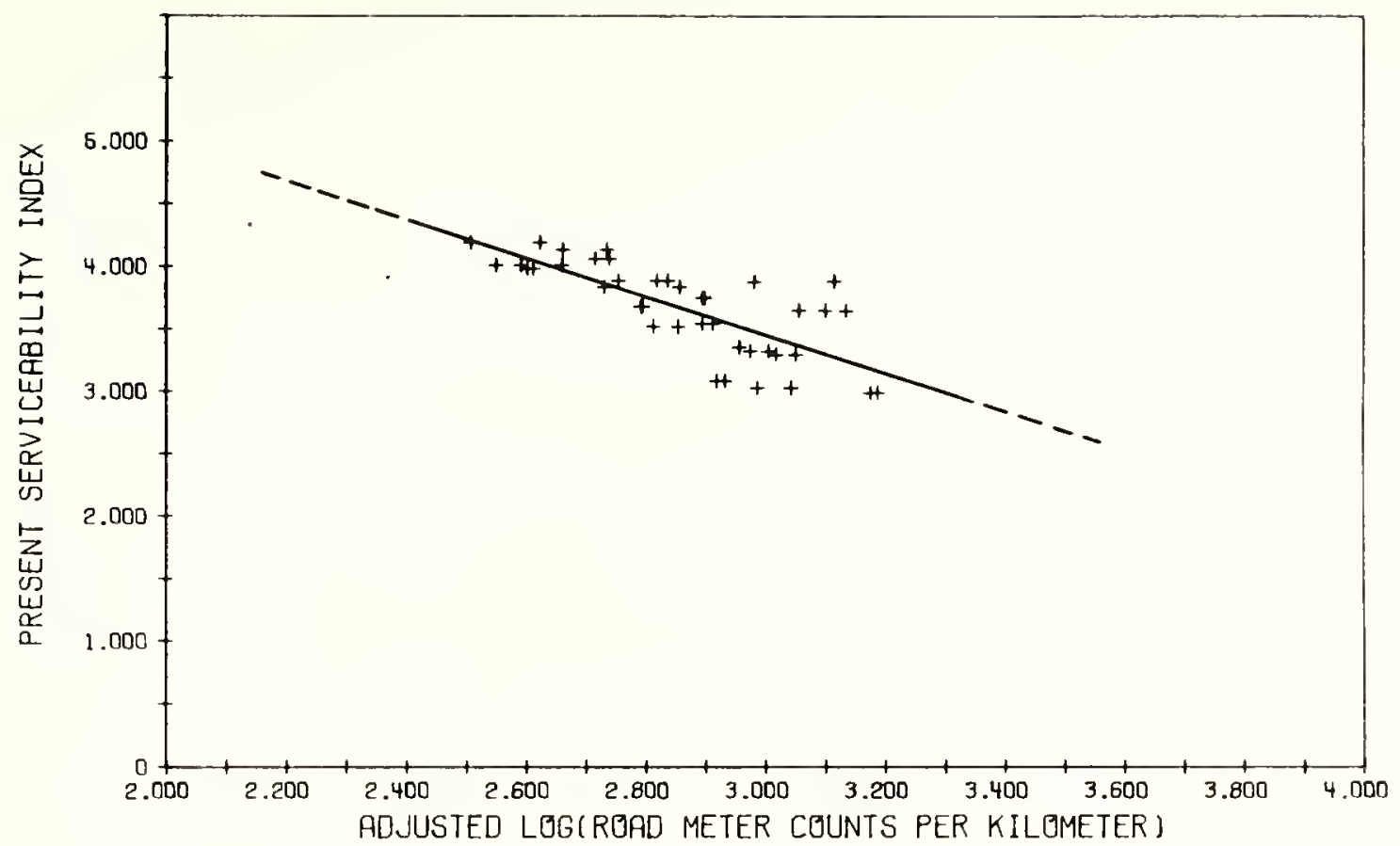

Figure 22: Roadmeter Calibration, JRC Pavements

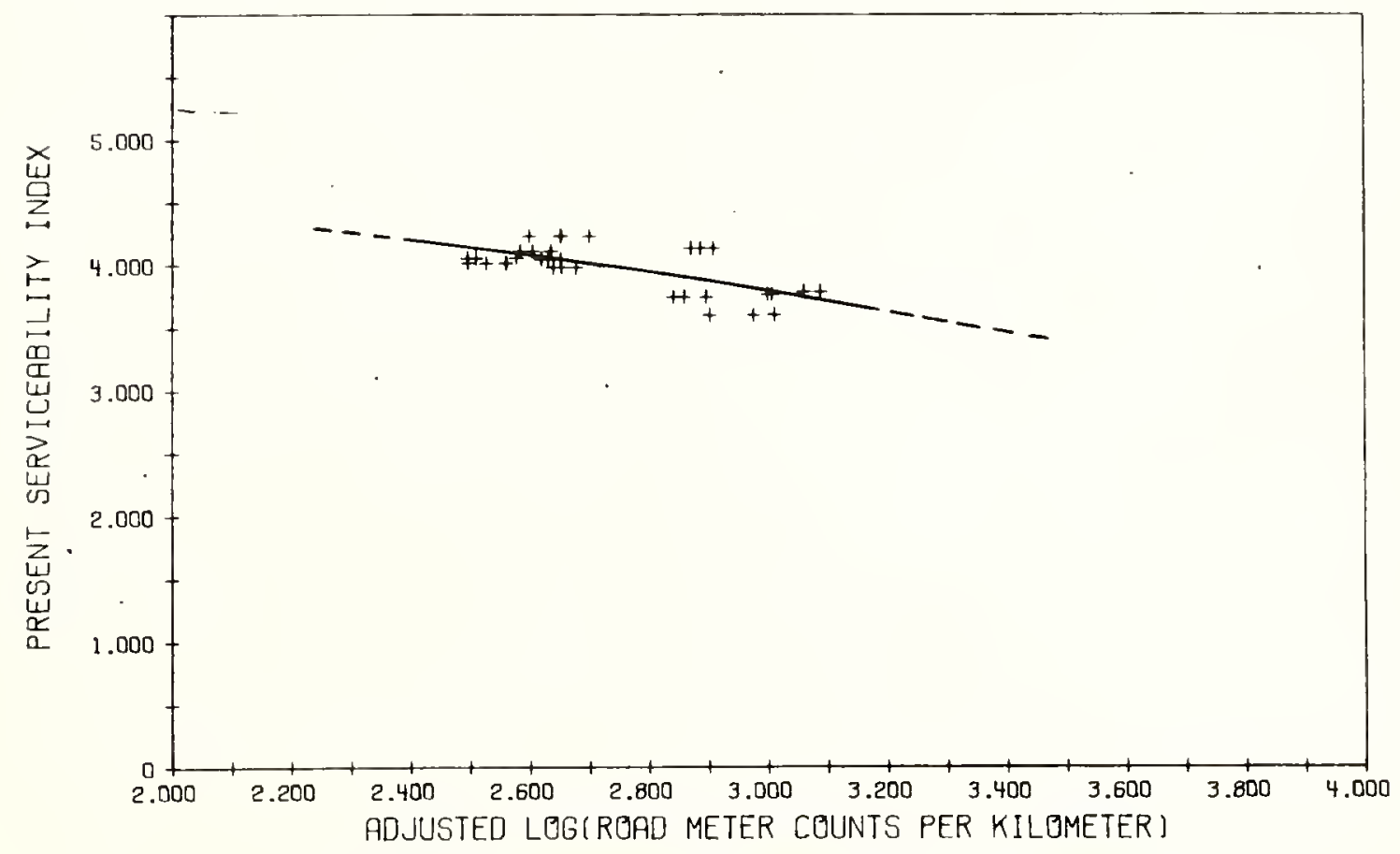

Figure 23: Roadmeter Calibration, CRC Pavements 


\section{Description of PSI Models}

Flexible Pavements. Three models were developed for flexible pavements, as given below:

Reduced Mode]

$$
\text { PSI }=-9.2556+10.3244(\log x)-2.0480(\log x)^{2}
$$

Ful1 Mode] (1)

$$
\begin{aligned}
\text { PSI }= & -5.3513+8.1159(\log X)-1.6764(\log x)^{2} \\
& -.02674 \sqrt{P}-5.1253(R D)+8.02907(R D)^{2}
\end{aligned}
$$

Ful 1 Mode1_(2)

$$
\begin{aligned}
\text { PSI }= & -4.6788+8.06833(\log X)-1.7308(\log X)^{2} \\
& -.02612 \sqrt{P}-22.6976(R D)+6.1536(R D)^{2} \\
& +.5329(W)(R D)+4.0291(\log X)(R D)
\end{aligned}
$$

Important properties of the flexible pavement models are given in Table D8 of Appendix D.

Overlay Pavements. Two full models and one reduced model were developed for overlay pavements. In one of the two full models, surface cracks were measured using the AASHO definition for flexible pavement cracks and in the other using the AASHO definition or rigid pavement cracks. The surface condition of an overlay pavement will be used to decide which of the two models will be more appropriate. Reduced Mode]

$$
\text { PSI }=18.7414-9.5708(\log x)+1.4231(\log x)^{2}
$$

Ful1_Model - Cracks defined as for rigid pavements

$$
\begin{aligned}
\text { PSI }= & 14.6833-7.2991(\log X)+1.1157(\log X)^{2} \\
& -.07731 \sqrt{P}+.4658(T)-.09549 \sqrt{P}(S D) \\
& -.00763(W)(C)+.5753(S D)(F)
\end{aligned}
$$


Full Model - Cracks defined as for flexible pavements

$$
\begin{aligned}
\text { PSI }= & 12.4358-5.7762(\log X)+.8653(\log X)^{2} \\
& -.05944(\sqrt{P})+.00006204(C)^{2}+.4512(S D) \\
& -.3757(\sqrt{P})(S D)-.01261(C)(T)+.04208(W)(T)
\end{aligned}
$$

Important properties of the overlay pavement models are given in Table D9 of Appendix D.

JRC Pavements. One FuTl Model and one Reduced Model were developed for JRC pavements as below:

Reduçed Mode]

$$
\text { PSI }=8.0677-1.5387(\log X)
$$

Ful] Mode]

$$
\begin{aligned}
\text { PSI }= & 31.6758-10.5486(\log X)+.02143(P) \\
& -.2631(\sqrt{P})-1.9882(W)+.7585(\log X)(W) \\
& -.05005(S D)(W)
\end{aligned}
$$

Important properties of the JRC pavement models are given in Table D10 of Appendix D.

CRC Pavements. One full model and one reduced model were developed for CRC pavements, a]so, as below:

Reduced Mode]

$$
\text { PSI }=4.9354-.1274(\log x)^{2}
$$

Fu11 Mode1

$$
\begin{aligned}
\text { PSI }= & -1.2665-2.197(\log x)^{2}+.0002537\left(C^{2}\right) \\
& -.01244(C)+.06973(\sqrt{P})-.05425\left(W^{2}\right) \\
& -.004894(\sqrt{P})(C)+.8807(\log x)(W)
\end{aligned}
$$

Important properties of the CRC pavement models are given in Table D11 of Appendix D. 
In all the 10 models given above in Equations 10 to 19 , the various symbols are defined as follows:

$X=$ Roadmeter counts per kilometer

$P=$ Patched area in sq. ft. per $1000 \mathrm{sq}$. ft. of surfacing

$R D=$ Rut depth of outer wheel path in inches

$W=$ Effective width of travel lane in $\mathrm{ft}$.

$T=$ Type of terrain; $T=1$ if terrain is flat and $T=0$ if terrain is rolling.

$S D=$ Sight distance; $S D=1$ if sight distance is poor and $S D=0$ if sight distance is fair to good.

$C=$ cracked area in Sq. ft. per 1000 sq. ft. of surfacing;

$C=C l$ ass 2 cracks + Class 3 cracks for flexible pavements;

$C=$ Class 3 cracks + Class 4 cracks for rigid pavements

$F=$ Type of facility; $F=1$ for two-lane facilities and $F=0$ for multilane facilities.

A11 logarithms are to the base 10 .

\section{Recommended Procedure to Determine Sufficiency Ratings from PSI Values}

One of the objectives of this study was to replace the presently used procedure of the Indiana State Highway Commission of assigning subjective numeric values called 'sufficiency ratings' to describe the rideability of pavements, by objectively measured values. The PSI models described above are recommended to be used to determine the present serviceability (PSI) of pavements using roadmeter measurements and values of other influencing variables. These PSI values of pavements can then be related to the sufficiency ratings as in Table 18 , so 
Table 18: Determination of Sufficiency Ratings from PSI Values

\begin{tabular}{l|c|c|c}
\hline \multicolumn{2}{c|}{ Existing Procedure } & \multicolumn{2}{c}{ Recommended Procedure } \\
\hline $\begin{array}{c}\text { Judged } \\
\text { as }\end{array}$ & $\begin{array}{c}\text { Sufficiency } \\
\text { Rating }\end{array}$ & PSI & $\begin{array}{c}\text { Sufficiency } \\
\text { Rating }\end{array}$ \\
\hline Excellent & 5 & 4.1 to 5.0 & 5 \\
Good & 3 & 3.1 to 4.0 & 3 \\
Fair & 1 & 2.1 to 3.0 & 1 \\
Poor & 0.0 to 2.0 & 0 \\
\hline
\end{tabular}

as to tie the roadmeter output and other measurements to the existing system. The sufficiency ratings suggested in Table 18 are based on the remarks given on the scale from 0 to 5 of the rating card (Figure 11) used to assign present serviceability ratings (PSR) of pavements.

These remarks are similar to those used in assigning sufficiency ratings (Table A1 of Appendix A).

\section{Temporal Stability of the PSI Models}

The roadmeter is an expeditious and reliable means of measuring the roughness of pavements and when calibrated against the mean PSR of road users, it can directly read the PSI of pavements. However, periodic checks on the accuracy and temporal stability of roadmeter measurements are required for the following reasons:

1. Shock absorbers may change their original spring action with time or the cable hookup to the console assembly may gradually change.

2. Time and social changes may influence the expectation levels of road users and their ratings. 
Periodic checks on the PSI models are therefore necessary. For a check procedure to be practical, it should be simple to follow and analyze, and should consume minimum resources.

\section{Theoretical Analysis}

The objective is to check the stability of regression coefficients over time due to structural changes in the roadmeter and/or due to changes in the attitudes of road users. Since roadmeter output alone explains most of the variation in PSR, reduced models as in Equations $10,13,16$ and 18 may be adequate for this purpose. After the statewide inventory of pavements is completed and a mechanism to regularly update the various properties of pavements is in action, it may be equally convenient and rather advisable to include all variables.

If the original model is of the form

$$
Y=A_{0}+A_{1} X+\varepsilon
$$

where: $Y=$ PSI

$X=R M$ output

and, $T$ is a dummy variable representing effect of time on PSI models, such that

$T=0$, if the measurements were recorded at time 0 (time when PSI models were first formulated), and

$T=1$, if the measurements were recorded at time $t$ (time when a check on PSI models is being done),

the new model will take the form (11)

$$
Y=A_{0}+A_{1} X+A_{2} T+A_{3} T \cdot X+\varepsilon
$$


The hypothesis of interest will be

$$
H_{0}: \quad A_{2}=A_{3}=0
$$

If the above hypothesis is rejected it will be necessary to revise the PSI models.

\section{Recalibration Procedures}

It is not possible, at this stage, to specify exactly when a PSI model needs revalidation check. A few initial checks done on PSI models at intervals will guide in developing a specification regarding the frequency of recalibration checks. The initial checks when considered necessary may be carried out according to the following procedure:

1. Select about 40 test sections, each one kilometer long, such that about 10 test sections belong to each of the four pavement types. Each pavement type should include pavements with low to high serviceability ratings. The 40 test sections should be arranged in one or two loops.

2. Select 5 raters and get their ratings of the 40 pavement sections. The 5 raters should represent both sexes, all age groups and all car sizes. The rating time of each rater should be randomized between morning and afternoon sessions and all ratings should be completed within one week.

3. Run the roadmeter twice over the loops containing the 40 test sections. If there is more than one loop, the order of roadmeter runs should be randomized.

4. Adjust the logarithms of RM counts for air temperature and gas tank level. 
5. Pool the data now collected with the data collected for developing the PSI models now under check.

6. Regress the pooled roadmeter measurements on pooled mean PSR's. Separate regression should be run for each pavement type. All the terms in the reduced model of each pavement type, a dummy independent variable ' $T$ ' and 211 two factor interactions of $T$ with RM output terms should be included in this regression analysis (Equation 21).

7. If the factor $T$ or any interaction term including $T$ is found significant a revision of PSI models is necessary (11). If not, the existing PSI models are good for continued use.

8. If a revision is necessary, develop new PSI models using the fresh data only. 


\section{CHAPTER 5: DEFLECTION STUDIES}

\section{Purpose of the Study}

Determination of PSI values as discussed in Chapter 4 yield data on where maintenance should be done. This chapter deals with methods of determining the type of required maintenance using deflection as a criterion. Many researchers have shown the reliability of deflection measurements for determining maintenance type $(1,9,18)$. Hence for this study, it is assumed that methods presently available can be adopted for Indiana but data are needed on the optimal method for taking these measurements.

In the context of this research, deflection studies were undertaken for the purpose of seeking answers to the three questions given below. In a) 1 cases use was made of the dynaflect shown in Figures 24 and 25.

1. At what location across the lane, should the deflections be measured?

2. How many measurements per unit of longitudinal length should be taken?

3. Can the deflection measurements taken in fall season be used or should all measurements be made in the spring?

\section{Study Plan}

\section{Selection of Test Sections}

Ninety four test sections were earlier selected for pavement serviceability studies following the criteria explained in Chapter 3 . The test 


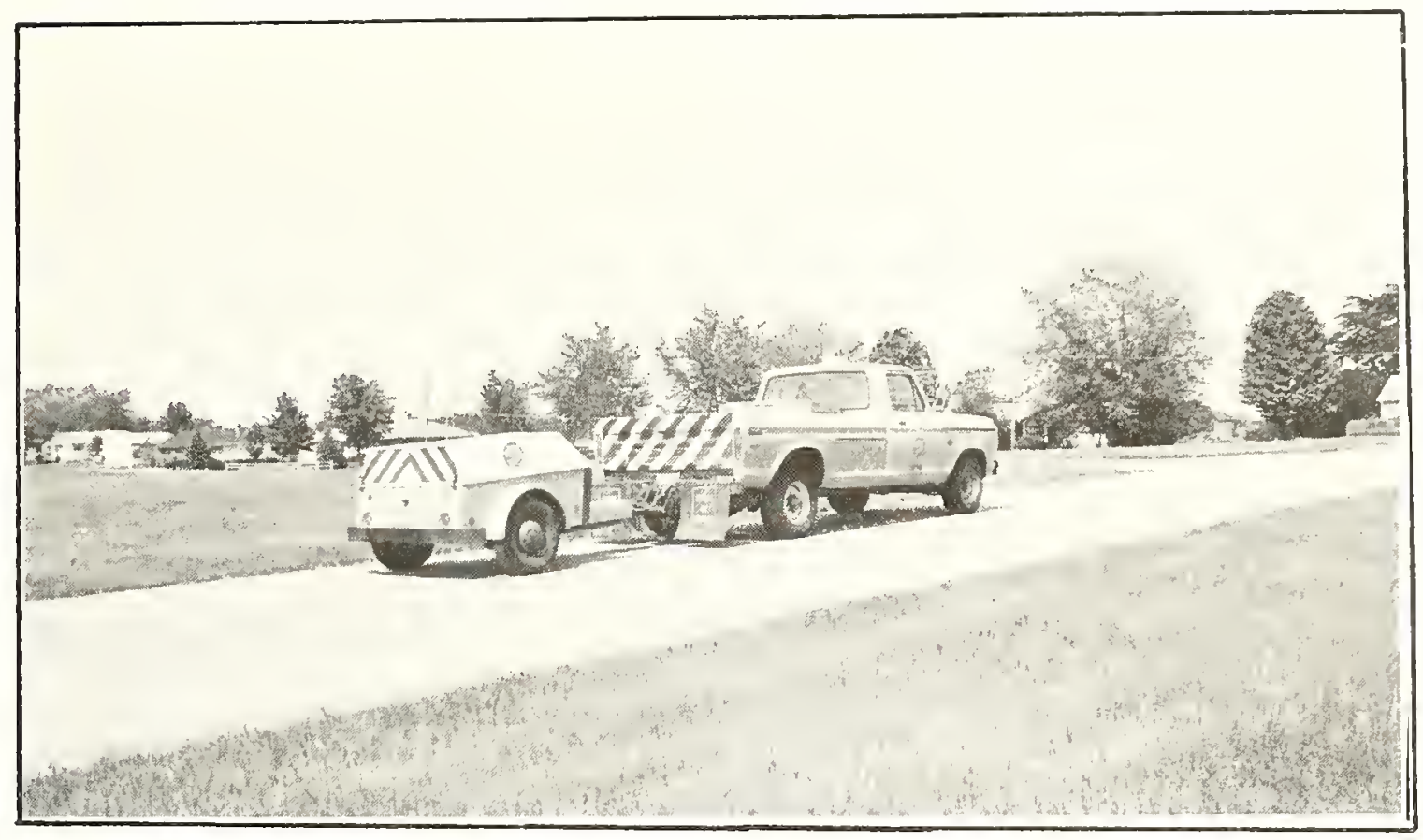

Figure 24: The Indiana State Highway Commission's Dynaflect

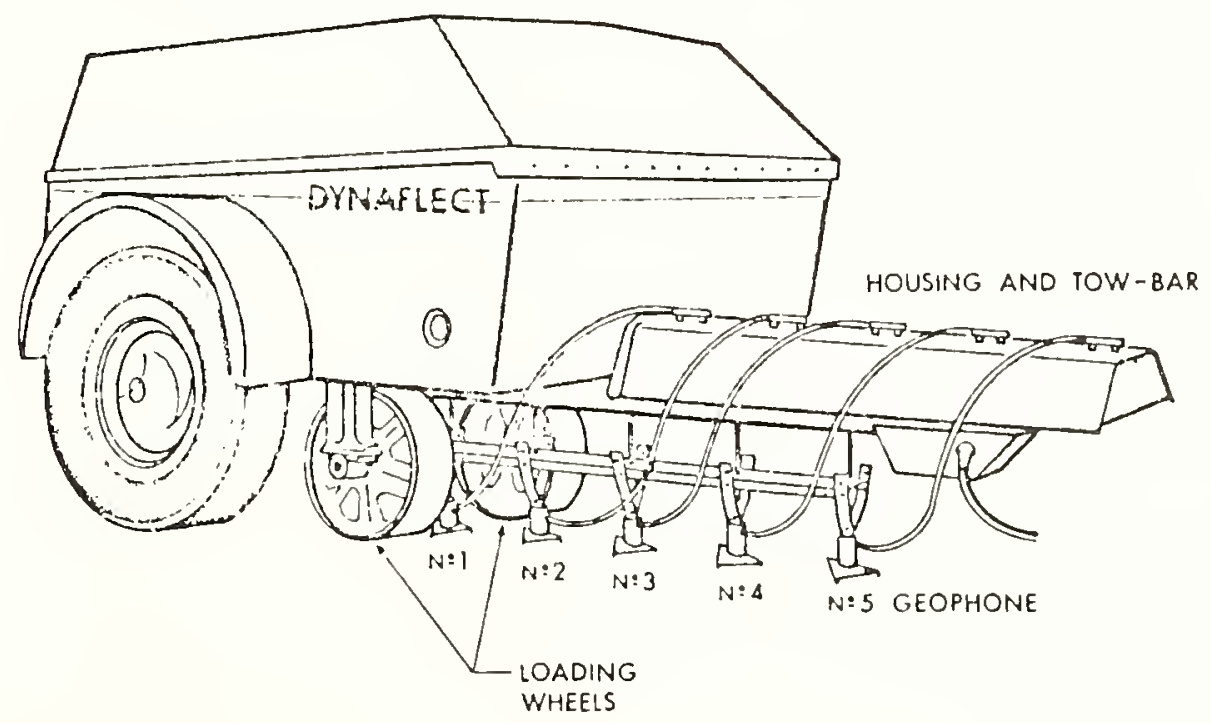

Figure 25: Dynaflect in the Operating Position (From Chong, G.J., et al.) 
sections for the deflection studies were selected from these 94 test sections on the basis of following properties of each test section:

1. Pavement type

2. Roughness group

3. Subgrade soil type

4. Pavement thickness

5. Traffic intensity

Pavements were divided into 4 types as in Table 4 , and surface roughnesses into 3 groups as in Table 5 (Chapter 2).

Subgrade type, used in the study was based on AASHTO soil classification for each test section. The classification was established by referring to engineering soil parent material map*. Soils were grouped into two categories, granular $A 1, A 2$ and $A 3$ and fine grained $A 4, A 5, A 6$ and $A 7$.

Pavement thickness values of the test sections were taken from the Road Life data of the Indiana State Highway Commission and effective thickness of each pavement section was calculated using the Asphalt Institute Conversion factors (3).

For the two traffic volume groups, sections carrying an ADT of 3500 vpd or less in 1975 were placed into category 1 and those carrying more than 3500 vpd in category 2 .

Since climate has an effect on the performance of pavements, annual rainfall and maximum mean daily temperature differentials of the counties in which the 94 test sections fell, were studied. Records of the period 1931-1960 showed that the annual rainfall in the study area ranged from 
$36^{\prime \prime}$ to $40^{\prime \prime}$ and the maximum mean daily temperature differential ranged from $65^{\circ} \mathrm{F}$ to $69^{\circ} \mathrm{F}(29)$. Both these ranges were negligible with in the study area and therefore this factor could not be included in this study.

Forty six test sections representing various combinations of the above given five properties as given in Table El of Appendix E were selected for deflection studies.

\section{Deflection Measurements}

As was done for the rut depth measurements and for the measurements of cracking and patching, Dynaflect measurements were made in a 400 meter long subsection randomly located within the one kilometer long test section.

Locations Across the Lane. Deflections were measured at three 10cations across the lane. The locations of tests were at $2 \mathrm{ft}$. from the outer edge (hereafter called 'edge'), at the center of lane (hereafter called 'center') and at $2 \mathrm{ft}$. from the inside edge (hereafter called 'inner'). The two outer locations (edge and inner) were assumed to represent the two whee] paths and the center of lane (center) location was chosen for comparison of means and variation patterns of the edge and inner deflections with the center deflection.

Number of Deflection Measurements. The 400 meter long subsection was divided into 20 parts each 20 meters in length. Deflection measurements were taken at the 3 locations given above at each of the 21 reference lines from 0 to 20 . Thus, 63 deflection tests were done in each subsection as shown in Figure 26.

Period of Measurement. Fall measurements were made during the period of October 12, 1977 to November 22, 1977, and the spring 


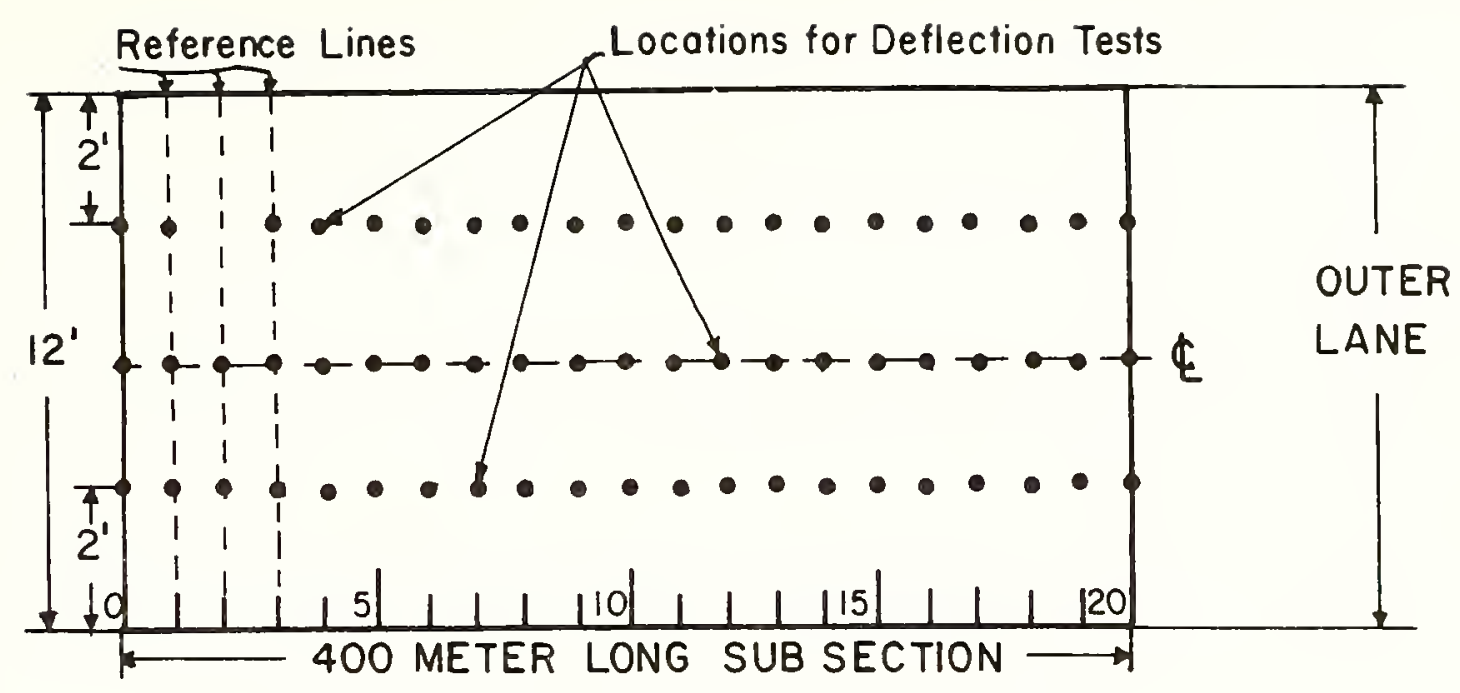

(Not to Scale)

Figure 26. Locations of 63 Deflection Tests

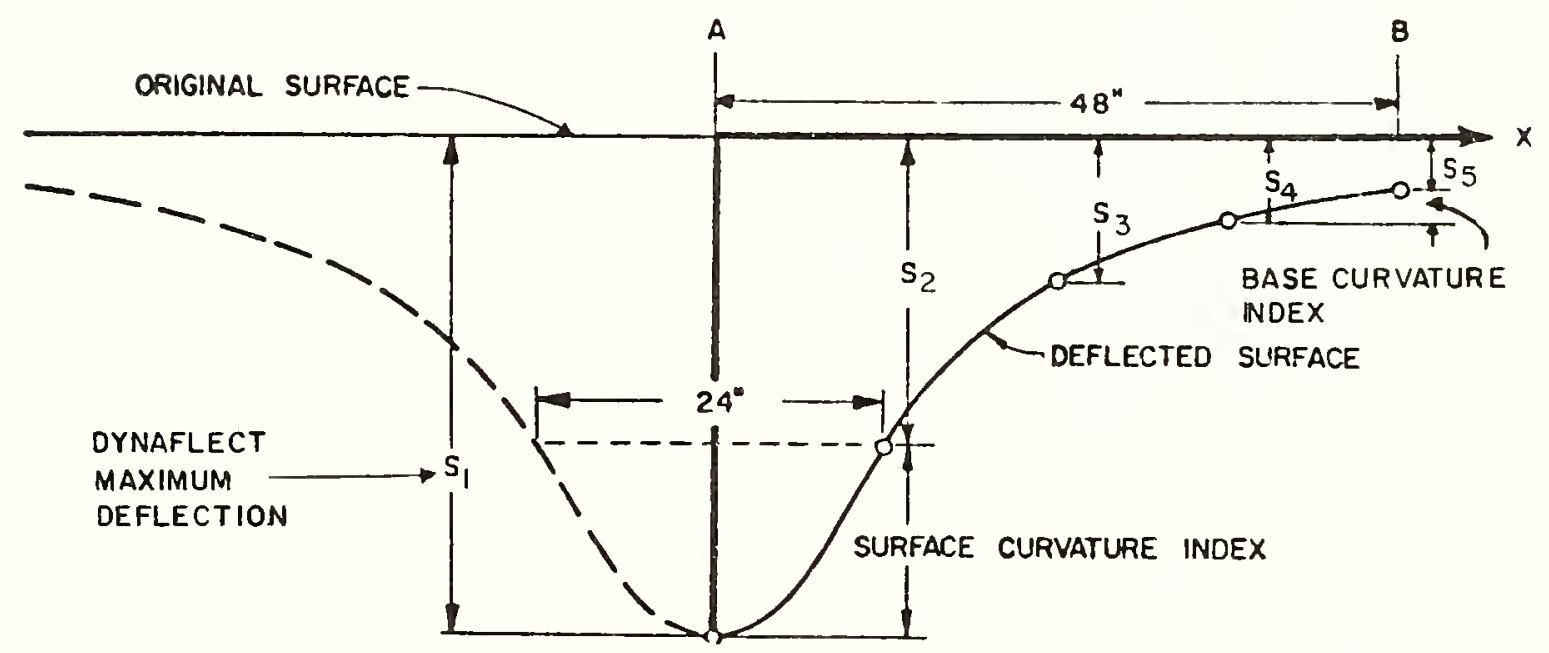

Figure 27. A Typical Deflection Basin (After NCHRP report no. 76) 
measurements were made from April 27, 1978 to June 7, 1978. Of the 46 test sections selected for this study, 42 could be tested for deflection during fall 1977 and 44 during spring 1978. Of those tested, 41 test section were common to both seasons and were used for correlation purposes.

\section{Selection of an Optimal Test Location}

Across the Width of Pavement

Three locations across the width of pavement were selected as described above, and 21 tests spaced at 20 meters were taken at each location in each 400 meter long subsection. In the subsequent analyses these 21 sections are termed as Reference lines (Figure 26). During the fall of 1977, deflection measurements were made on 42 test sections and these data were used for arriving at the optimal location.

\section{Deflection Basin Parameters}

Four parameters or indexes, computed as below from the dynaflect measurements have been used for determining the structural strength of various pavement layers $(34,42)$.

1. Dynaflect Maximum Deflection (DMD)

$$
D M D=S 1
$$

2. Base Curvature Index (BCI)

$$
\mathrm{BCI}=\mathrm{S} 4-\mathrm{S} 5
$$

3. Surface Curvature Index (SCI)

$$
S C I=S 1-S 2
$$

4. Spreadability (SPD)

$$
S P D=\frac{(S 1+S 2+S 3+S 4+S 5) \times 100}{5 \times S 1}
$$


Where, S1, S2, S3, S4 and S5 are deflections at Sensor No. 1, Sensor No. 2, Sensor No. 3, Sensor No. 4, and Sensor No. 5, respectively.

Three of these indices, DMD, BCI and SCI are illustrated in Figure 27.

The four deflection indices, defined above, were computed for each of the three locations on a reference line and all analyses were done on these four parameters only (Tables E2 to E5 of Appendix E).

\section{Selection Criteria}

Three criteria were formulated to serve as a guide in the selection of an optimal location.

1. The location should require a minimum number of deflection measurements for estimating the true deflection of the pavement. This criterion required that the location having minimum variance between the 21 deflection measurements should be the likely choice.

2. The location should be worthy of commanding acceptability of the practicing engineers. This criterion was to take care of the practical aspects of deflection measurements in terms of management of traffic, safety of Dynaflect crew and convenience in measurement.

3. The measured deflections which will be used for the design of pavement strengthening should take care of the critical areas, i.e., those areas which fail or show signs of failure earliest. 


\section{Data Analysis}

Organization of Data. Forty two test sections tested during the fall of 1977 were used for this part of the study. The four pavement types in these 42 test sections are represented as below:

Flexible pavements 13

Overlay pavements 13

JRC pavements $\quad 11$

CRC pavements $\quad 5$

Sixty three deflection tests were made in each test section. For each test made the four deflection basin parameters were computed. The 21 values of each parameter were then averaged for each of the three 10cations (inner, center and edge). These average values with their standard deviations are tabulated in Tables E2 to E5 of Appendix E.

Test for the Significance of the Three Locations. As a first step in data analysis, a test was made on the data to determine if locations had a significant effect on the Dynaflect output. The four deflection parameters for each measurement $(3 \times 21 \times 42)$ were used as dependent variables and the following model was tested.

$$
Y=A_{0}+A_{1} T+A_{2} L+A_{3} R
$$

where $Y=$ Deflection parameter

$$
\begin{aligned}
& T=\text { Effect of Test Section } \\
& L=\text { Effect of Location (Transverse; edge, center or inner) } \\
& R=\text { Effect of Reference Line (Longitudinal location) }
\end{aligned}
$$

Sixteen regression analyses were done, one each on the four deflection parameters within each of the four pavement types. These regression analyses generally showed the following: 
1. Effect of test section is significant

2. Effect of location across the pavement is significant in the majority of cases.

3. Effect of reference line (1ongitudinal location) is not significant.

Thus although the reference lines were selected in a fixed way the tests showed that they really behave in a random fashion.

In the next step, ANOVA was done on the $\log$ of variance $\left(\log s^{2}\right)$ of each deflection parameter to further examine the effect of Test Section and Location; using the following model $(2,7)$ :

$$
Y_{i j}=B_{0}+B_{1} T_{i}+B_{2} L_{j}+B_{3} T_{i} L_{j}
$$

where,

$$
\begin{aligned}
\gamma_{i j}= & \log s^{2}, S \text { belonging to the } i \text { th deflection } \\
& \text { parameter and } j \text { th pavement type ( } i \text { and } j=1 \text { to } 4 \text { ) }
\end{aligned}
$$

Again 16 ANOVA tests were made. The results are summarized in Table E6 of Appendix E. Newman-Keuls tests were done on the means of. each of the 4 deflection parameters for each test section (42 nos.) to examine if the mean value at one of the three locations was significantly different from the mean value at the remaining two locations. The results of ANOVA and Newman-Keuls tests are summarized as below:

1. With regard to Tocation across the pavement, the four pavement types behaved differentiy.

2. For Flexible Pavements, the effect of location across the pavement was very significant.

(ii) In all sections, edge DMD's were higher than the center DMD's which in turn were higher than the inner DMD's. Mean 
values of all deflection parameters for each location are given in Table 19. The differences in means of deflection parameters were significant for rough and average pavements and not significant for smooth pavements .

(iii) Pooled standard deviations and 80 percentile deviations of each deflection parameter for each location are given in Table 20. Both forms of deviations show an increasing trend as deflection location changes from inner to edge.

3. For Overlay Pavements, the effect of locations was not statistically significant (Table E6).

(ii) In most cases, the edge DMD's were higher than the center DMD's, but between the center and inner DMD's there was no obvious dominance of one location over the other as was the case with flexible pavements. Mean values of the four deflection parameters for each 10cation are given in Table 19 .

(iji) Pooled standard deviations and 80 percentile deviations of the four deflection parameters are given in Table 20 . No obvious pattern between the standard deviations of various parameters was observed.

4. For JRC Pavements, the effect of locations was significant for the two dominant parameters $\mathrm{DMD}$ and $\mathrm{BCI}$ only. In the context of JRC pavements, SCI does not have the same significance as for flexible pavements because of the type of pavement.

(ii) Except for one test section, the edge DMD was always highest. In most cases the center DMD was higher than the 
Table 19: Mean Values of Deflection Parameters Fal1 1977 Data

FLEXIBLE PAUEMENTS

\begin{tabular}{rrrr}
\hline & INNER & CENTER & \multicolumn{1}{c}{ EDGE } \\
\hline DMD & 1.602 & 1.729 & 1.948 \\
BCI & 0.148 & 0.151 & 0.161 \\
SCI & 0.421 & 0.447 & 0.583 \\
SPD & 55.250 & 54.220 & 53.120 \\
\hline
\end{tabular}

OUERLAY PAUEMENTS

\begin{tabular}{rrrr}
\hline & INNEF & CENTER & \multicolumn{1}{c}{ EDGE } \\
\hline DMD & 0.730 & 0.736 & 0.852 \\
BCI & 0.095 & 0.053 & 0.108 \\
SC1 & 0.098 & 0.090 & 0.123 \\
SPD 71.890 & 71.660 & 71.230 \\
\hline
\end{tabular}

JRC PAUEMENTS

\begin{tabular}{rrrr}
\hline & INNER & CENTER & \multicolumn{1}{c}{ EDGE } \\
\hline DMD & 0.524 & 0.550 & 0.604 \\
BCI & 0.061 & 0.065 & 0.077 \\
SCI & 0.034 & 0.036 & 0.048 \\
SPD 77.890 & 77.370 & 76.680 \\
\hline
\end{tabular}

CRC PAUEMENTS

\begin{tabular}{rrrr}
\hline & INNER & CENTER & \multicolumn{1}{c}{ EDGE } \\
\hline DMD & 0.339 & 0.387 & 0.448 \\
BCI & 0.053 & 0.050 & 0.062 \\
SCI & 0.0 .14 & 0.053 & 0.045 \\
SPD & 72.170 & 72.940 & 72.390 \\
\hline
\end{tabular}


Table 20: Standard Deviations of Deflection Parameters Fa11 1977 Data

FLEXIELE FPUEMENTS

\begin{tabular}{|c|c|c|c|c|c|c|}
\hline & \multicolumn{2}{|c|}{ IIUMER } & \multicolumn{2}{|c|}{ CENTER } & \multicolumn{2}{|c|}{ EDCE } \\
\hline & & EOTH PER & & BOTH PER & & 80TH PER \\
\hline & PDDLED & CENT ILE & PODLED & CENTILE & PODLED & CENTILE \\
\hline & STD.DEU= & STD.DEU. & STD.TJEU. & STD.DEU. & STD. DEU. & STD.DEU. \\
\hline DMD & 0.3519 & 0.3152 & 0.5053 & 0.3496 & 0.5521 & 0.4804 \\
\hline $\mathrm{BCI}$ & 0.0480 & 0.0426 & 0.0522 & 0.0448 & 0.0558 & 0.0476 \\
\hline SCI & 0.1401 & 0.1416 & 0.2218 & 0.1644 & 0.2638 & $0 . i \varepsilon 94$ \\
\hline SPI & 3.4150 & 3.6700 & 3.1030 & 3.6880 & 3.3770 & 3. उЕट0 \\
\hline
\end{tabular}

DUERLAY PAUEMENTS

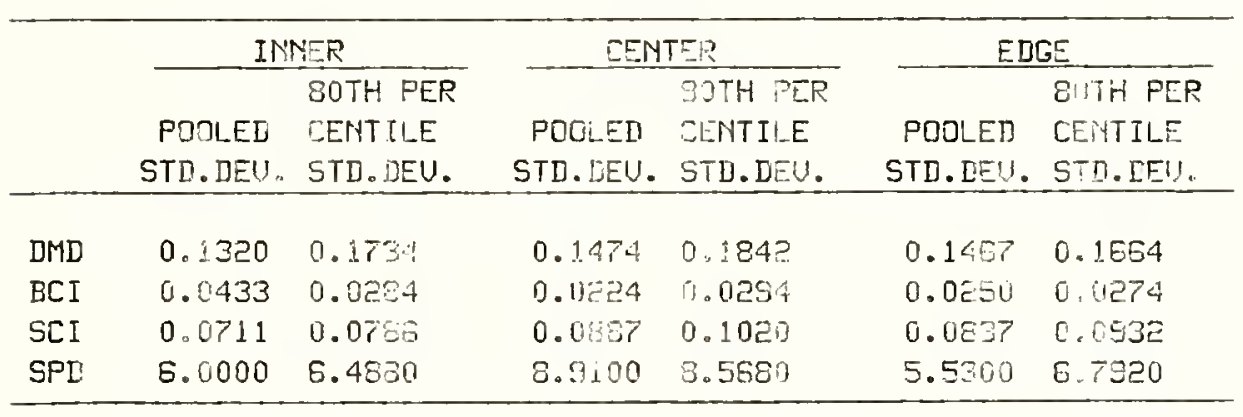

JRC PAUEMENTS

\begin{tabular}{|c|c|c|c|c|c|c|}
\hline & \multicolumn{2}{|c|}{ IIIMER } & \multicolumn{2}{|c|}{ CENIER } & \multicolumn{2}{|c|}{ EDGE } \\
\hline & & SOTH PER & & 597H DER & & 8UTH PER \\
\hline & PODLED & CEPTILE & POCLED & CEHTILE & POOLED & CNMTILE \\
\hline & STM. IEU. & STD.DEU. & STD. DEU. & SID.DEU. & STD.IEU. & STD.DEU. \\
\hline$D M D$ & 0.1207 & 0.1624 & 0.1431 & 0.1438 & $0.1 E Q P$ & 0.1992 \\
\hline $\mathrm{BCI}$ & 0.0191 & 0.0250 & 0.0291 & $0.030 \mathrm{c}$ & $0.0=84$ & $0.03 E E$ \\
\hline SCI & 0.0358 & $0.04: 8$ & $0 . \Gamma: 19$ & 0.0443 & 0.1004 & 0.03636 \\
\hline SPI & 10.2800 & E. 2780 & 10.4200 & 5.6260 & $10.5 E 00$ & 6.0080 \\
\hline
\end{tabular}

CRL PAUEMENTS

\begin{tabular}{|c|c|c|c|c|c|c|}
\hline & \multicolumn{2}{|c|}{ IMriER } & \multicolumn{2}{|c|}{ CENTER } & \multicolumn{2}{|c|}{ EDGE } \\
\hline & & 80TH PER & & BOTH DER & & 8ITH PEP \\
\hline & PODLED & CENTILE & POOLED & CENTILE & POOLED & CENTILE \\
\hline & STD. DEU. & STD.DEU. & STD. IEU. & STD.DUU. & STD. IEU. & STD.DEU. \\
\hline DMD & 0.0533 & $0.0 E ? 0$ & 0.0 .456 & 0.0483 & 0.1010 & 0.1350 \\
\hline $\mathrm{BCI}$ & 0.0214 & 9.0150 & 0.0118 & 0.0150 & 0.0148 & 0.0150 \\
\hline SCI & 0.0253 & 0.0350 & 0.1232 & 0.0270 & 0.0346 & 0.0430 \\
\hline SPD & 3.8000 & 4.4800 & $3.4=00$ & 3.5000 & 4.2400 & 4.3400 \\
\hline
\end{tabular}


inner DMD. Mean values of the four deflection parameters for each location are given in Table 19.

(iii) Table 20 shows that pooled standard deviations increase from inner to edge location but the 80 percentile value of DMD does not show this trend.

5. For CRC Pavements, the effect of location was significant only for DMD which is the dominant property for this pavement type.

(ii) The edge DMD's were highest in all test sections but no trend was obvious between the center and inner deflections. The mean values of the 4 deflection parameters, however, showed that the center deflection parameters had minimum values and edge values were higher than the inner ones.

(iii) Also, the standard deviations for center location were minimum (Table 20). There was no obvious pattern between the standard deviations of deflection parameters at the edge and inner locations.

\section{Recommendations}

Taking gross deflection (DMD) as a representative parameter the analysis of data has revealed that the 80 th percentile values of variances at the edge are 90 percent higher than the 80 th percentile values of variances at the center for flexible and JRC pavements, are about 700 percent higher for CRC pavements and are about 20 percent lower in the case of overlay pavements (Table 21). Since the number of deflection tests required are directly proportional to the variances more observations are as a rule required if deflection tests are made at the edge. 
Table 21: Comparison of 80th Percentile Variance at Edge and Center

\begin{tabular}{lccc}
\hline $\begin{array}{l}\text { TYPE OF } \\
\text { PAUEMENT }\end{array}$ & 80TH PERCENTILE UALUES OF UARIANCE AT & $\begin{array}{l}\text { EDGE UALUES U/S } \\
\text { CENTER UALUES }\end{array}$ \\
\cline { 2 - 4 } & EDGE LOCATION & CENTER LOCATION & \\
FLEXIBLE & .2308 & .1222 & +89 PERCENT \\
OUERLAY & .0277 & .0339 & -18 PERCENT \\
JRC & .0397 & .0207 & +92 PERCENT \\
CRC & .0182 & .0023 & +691 PERCENT \\
\hline
\end{tabular}

However, the mean values of gross deflections (DMD's) given in Table 19, for each pavement type show that edge values are 10-15 percent higher than the center values. Since pavements almost always show signs of distress at the edges, first, edge deflections reflect the pavement characteristics of the weakest part and deserve consideration for being used as a design base.

In view of the above discussion, the following recommendations are made.

1. Wherever possible deflections should be measured at the edge location, i.e., $2 \mathrm{ft}$. from the outer edge, except for pavements which have been widened.

2. Where the old pavements have been widened, deflections should be taken at $2 \mathrm{ft}$. from the edge of old pavement. 
3. In lieu of the above, correlations between edge and center deflections may be drawn for each pavement type and if necessary for various categories within each pavement type. Designs for strengthening can then be based on edge deflections calculated from center deflections.

\section{Number of Deflection Tests}

In this research, a 400 meter long subsection was randomly located within the 1 kilometer long test section, and 21 deflection tests were taken in the subsection along the edge, the center and the inner locations as defined earlier in this chapter. The number of deflection tests computed, therefore, will be applicable to 1 kilometer long sections having uniform pavement properties

The number of deflection tests required per unit lengtin have been calculated using equation ( 6$)$, developed in Chapter 2 , and given below:

$$
N=\left[\frac{\left(t_{\alpha}+t_{\beta}\right) \sigma}{c}\right]^{2}
$$

where, $\quad N=$ Number of deflection tests required per unit length

$$
\begin{aligned}
& \alpha=\text { probability of Type I error } \\
& \beta=\text { probability of Type II error } \\
& \sigma=\text { Error in measurement }
\end{aligned}
$$

The variance of gross deflection (DMD) has been used to compute the required number of tests, since this is the best known parameter and the magnitude of acceptable error, in DMD, is more easily understood.

The variances of DMD's for test sections within a pavement type were not homogenous. Logical groups were formed based on some earlier measured properties of test sections but the variances of subgroups so formed were 
also not homogenous at a significance level of .001. The California Division of Highways uses the 80th percentile deflection values in pavement evaluation (9). The 80th percentile values of DMD were used in computing the number of deflection tests required.

Number of deflection tests required to estimate the true deflection of a pavement section for various values of Type I and Type II errors and for a range of acceptable errors have been tabulated in Table 22. Since the variances of deflection measurements were widely different for each pavement type, the number of deflection tests have been calculated separately for each pavement type and for the two locations, edge and center, within each pavenent type.

\section{Relationship Between Spring and Fall Deflections}

Typical yearly fluctuations of DMD and SCI, for flexible pavements, as observed in Utah (34), are given in Figure 28. In Indiana, on the average, the spring 1978 edge DMD's were higher than the fall 1977 edge DMD's by 22 percent for flexible pavements, 26 percent for overlay pavements, 16 percent for JRC pavements and 23 percent for CRC pavements. While a part of these increases may be due to pavement deterioration in the 6 months period from fall 1977 to spring 1978, much of these increases in deflections is the result of spring thaw. The spring deflections are, thus, critical for design purposes. However, the critical period during spring thaw is very short and, in addition can be variable from year to year. On the other hand, the fall season is relatively long lasting for several months and the subgrade properties are quite stable during the period. A possible alternative then would be to estimate the spring deflections from the fall deflections. Such an approach would have a primary advantage in that the state highway department would 
Table 22: Number of Deflection Tests Required per Test Section

FLEXIBLE PAUEMENTS

CENTER DEFLECTIONS

\begin{tabular}{|c|c|c|c|c|c|c|c|c|c|c|c|c|c|}
\hline \multirow{2}{*}{$\begin{array}{l}\text { ACCEPTABLE } \\
\text { ERROR (DMD) }\end{array}$} & \multirow{2}{*}{$\begin{array}{l}\alpha \\
\beta\end{array}$} & \multicolumn{4}{|c|}{.05} & \multicolumn{4}{|c|}{1} & \multicolumn{4}{|c|}{.2} \\
\hline & & .05 & .1 & .2 & .5 & .05 & .1 & .2 &.$\overline{5}$ & .05 & .1 & .2 & .5 \\
\hline .10 & & 178 & 143 & 106 & 54 & 146 & 114 & 82 & 37 & 114 & 86 & 59 & 22 \\
\hline .15 & & 79 & 64 & 48 & 24 & 65 & 51 & 37 & 17 & 51 & 39 & 26 & 10 \\
\hline .20 & & 45 & 36 & 27 & 14 & 37 & 29 & 21 & 9 & 29 & 22 & 15 & 6 \\
\hline .25 & & 29 & 23 & 17 & 9 & 24 & 19 & 13 & 6 & 19 & 14 & 10 & 4 \\
\hline .30 & & 20 & 16 & 12 & 6 & 17 & 13 & 9 & 4 & 13 & 10 & 7 & 3 \\
\hline .35 & & 15 & 12 & 9 & 5 & 12 & 10 & 7 & 3 & 10 & 7 & 5 & 2 \\
\hline .40 & & 11 & 9 & 7 & 4 & 9 & 8 & 6 & 3 & 8 & E & 4 & 2 \\
\hline .45 & & 9 & 7 & G & 3 & 8 & 6 & 4 & 2 & 6 & 5 & 3 & 1 \\
\hline .50 & & 8 & G & 5 & 3 & G & 5 & 4 & 2 & 5 & 4 & 3 & 1 \\
\hline .60 & & 5 & 4 & 3 & 2 & 4 & 4 & 3 & 1 & 4 & 3 & 2 & 1 \\
\hline
\end{tabular}

FLEXIBLE PAUEMENTS

EDGE DEFLECTICNS

\begin{tabular}{lllllllllllllllllll}
\hline $\begin{array}{l}\text { ACCEPTABLE } \\
\text { ERROR(DMD) }\end{array}$ & $\beta$ & $\beta$ & \multicolumn{1}{c}{.05} & .1 & .05 & .5 & .05 & .1 & .2 & .5 & & .05 & .1 & .2 & .5 \\
\hline 10 & 336 & 269 & 201 & 101 & 275 & 215 & 155 & 69 & 215 & 162 & 111 & 41 \\
.15 & 149 & 120 & 89 & 45 & 122 & 96 & 69 & 31 & 96 & 72 & 49 & 18 \\
.20 & 84 & 68 & 50 & 26 & 69 & 54 & 39 & 18 & 54 & 41 & 28 & 11 \\
.25 & 54 & 43 & 32 & 16 & 44 & 35 & 25 & 11 & 35 & 26 & 18 & 7 \\
.30 & 38 & 30 & 23 & 12 & 31 & 24 & 18 & 8 & 24 & 18 & 13 & 5 \\
.35 & 28 & 22 & 17 & 9 & 23 & 18 & 13 & 6 & 18 & 14 & 9 & 4 \\
.40 & 21 & 17 & 13 & 7 & 18 & 14 & 10 & 5 & 14 & 11 & 7 & 3 \\
.45 & 17 & 14 & 10 & 5 & 14 & 11 & 8 & 4 & 11 & 8 & 5 & 2 \\
.50 & 14 & 11 & 8 & 4 & 11 & 9 & 7 & 3 & 9 & 7 & 5 & 2 \\
.60 & 10 & 8 & 6 & 3 & 8 & 6 & 5 & 2 & 6 & 5 & 3 & 2 \\
\hline
\end{tabular}


Table 22: Continued

OUERLAY PAUEMENTS

CENTER DEFLECTIONS

\begin{tabular}{|c|c|c|c|c|c|c|c|c|c|c|c|c|c|}
\hline \multirow{2}{*}{$\begin{array}{l}\text { ACCEPTABLE } \\
\text { ERROR (DMD) }\end{array}$} & \multirow{2}{*}{$\begin{array}{l}\alpha \\
B\end{array}$} & \multicolumn{4}{|c|}{.05} & \multicolumn{4}{|c|}{.1} & \multicolumn{4}{|c|}{.2} \\
\hline & & .05 & .1 & .2 & .5 & .05 & .1 & .2 & .5 & .05 & .1 & .2 & .5 \\
\hline .10 & & 50 & 40 & 30 & 15 & 41 & 32 & 23 & 10 & 32 & 24 & 17 & 6 \\
\hline .15 & & 22 & 18 & 13 & 7 & 18 & 14 & 10 & 5 & 14 & 11 & 8 & 3 \\
\hline .20 & & 13 & 10 & 8 & 4 & 10 & 8 & 6 & 3 & 8 & 6 & 4 & 2 \\
\hline .25 & & 8 & 7 & 5 & 3 & 7 & 5 & 4 & 2 & 5 & 4 & 3 & 1 \\
\hline .30 & & 6 & 5 & 4 & 2 & 5 & 4 & 3 & 2 & 4 & 3 & 2 & 1 \\
\hline .35 & & 4 & 4 & 3 & 2 & 4 & 3 & 2 & 1 & 3 & 2 & 2 & 1 \\
\hline .40 & & 3 & 3 & 2 & 1 & 3 & 2 & 2 & 1 & 2 & 2 & 1 & 1 \\
\hline .45 & & 3 & 2 & 2 & 1 & 2 & 2 & 2 & 1 & 2 & 2 & 1 & 1 \\
\hline .50 & & 2 & 2 & 2 & 1 & 2 & 2 & 1 & 1 & 己 & 1 & 1 & 1 \\
\hline .60 & & 2 & 1 & 1 & 1 & 2 & 1 & 1 & 1 & 1 & 1 & 1 & 1 \\
\hline
\end{tabular}

DUERLAY PAUEMENTS

EDGE DEFLECTIONS

\begin{tabular}{lrrrrrrrrrrrrrrr}
\hline $\begin{array}{l}\text { ACCEPTABLE } \\
\text { ERROR (DMD) }\end{array}$ & $\alpha$ & $\beta$ & .05 & .1 & .05 & .5 & .05 & .1 & .2 & .5 & & .05 & .1 & .2 & .5 \\
\hline 10 & 41 & 33 & 24 & 12 & 33 & 26 & 19 & 9 & 26 & 20 & 14 & 5 \\
.15 & 18 & 15 & 11 & 5 & 15 & 12 & 9 & 4 & 12 & 9 & 6 & 3 \\
.20 & 10 & 8 & 6 & 3 & 9 & 7 & 5 & 2 & 7 & 5 & 4 & 2 \\
.25 & 7 & 6 & 4 & 2 & 6 & 5 & 3 & 2 & 5 & 4 & 3 & 1 \\
.30 & 5 & 4 & 3 & 2 & 4 & 3 & 2 & 1 & 3 & 3 & 2 & 1 \\
.35 & 4 & 3 & 2 & 1 & 3 & 3 & 2 & 1 & 3 & 2 & 1 & 1 \\
.40 & 3 & 2 & 2 & 1 & 2 & 2 & 2 & 1 & 2 & 2 & 1 & 1 \\
.45 & 2 & 2 & 2 & 1 & 2 & 2 & 1 & 1 & 2 & 1 & 1 & 1 \\
.50 & 2 & 2 & 1 & 1 & 2 & 1 & 1 & 1 & 1 & 1 & 1 & 1 \\
.60 & 2 & 1 & 1 & 1 & 1 & 1 & 1 & 1 & 1 & 1 & 1 & 1 \\
\hline
\end{tabular}


Table 22: Continued

JRC PAUEMENTS

CENTER DEFLECTIONS

\begin{tabular}{lrrrrrrrrrrrrrrr}
\hline $\begin{array}{l}\text { ACCEPTABLE } \\
\text { ERROR (DMD) }\end{array}$ & $\alpha$ & $\alpha$ & .05 & .1 & .05 & .5 & .05 & .1 & .2 & .5 & .05 & .1 & .2 & .5 \\
\hline .05 & 121 & 97 & 72 & 36 & 99 & 77 & 56 & 25 & 77 & 58 & 40 & 15 \\
.08 & 47 & 38 & 28 & 14 & 39 & 30 & 22 & 10 & 30 & 23 & 16 & 6 \\
.10 & 30 & 24 & 18 & 9 & 25 & 20 & 14 & 7 & 20 & 15 & 10 & 4 \\
.12 & 21 & 17 & 13 & 7 & 17 & 14 & 10 & 5 & 14 & 10 & 7 & 3 \\
.15 & 14 & 11 & 8 & 4 & 11 & 9 & 7 & 3 & 9 & 7 & 5 & 2 \\
.18 & 10 & 8 & 6 & 3 & 8 & 6 & 5 & 2 & 6 & 5 & 3 & 2 \\
.20 & 8 & 6 & 5 & 3 & 7 & 5 & 4 & 2 & 5 & 4 & 3 & 1 \\
.22 & 7 & 5 & 4 & 2 & 5 & 4 & 3 & 2 & 4 & 3 & 2 & 1 \\
.25 & 5 & 4 & 3 & 2 & 4 & 3 & 3 & 1 & 3 & 3 & 2 & 1 \\
.30 & 4 & 3 & 2 & 1 & 3 & 3 & 2 & 1 & 3 & 2 & 1 & 1 \\
\hline
\end{tabular}

JRC PAUEMENTS

EDGE DEFLECT IGNS

\begin{tabular}{lrrrrrrrrrrrrrrrrr}
\hline $\begin{array}{l}\text { ACCEPTABLE } \\
\text { ERRQR(DMD) }\end{array}$ & $\alpha$ & $\beta$ & .05 & .1 & .05 & .5 & .5 & .05 & .1 & .2 & .5 & .05 & .1 & .2 & .5 \\
\hline .05 & 231 & 185 & 138 & 69 & 189 & 148 & 106 & 48 & 148 & 112 & 76 & 28 \\
.08 & 90 & 73 & 54 & 27 & 74 & 58 & 42 & 19 & 58 & 44 & 30 & 11 \\
.10 & 58 & 47 & 35 & 18 & 48 & 37 & 27 & 12 & 37 & 28 & 19 & 7 \\
.12 & 40 & 32 & 24 & 12 & 33 & 26 & 19 & 9 & 26 & 20 & 14 & 5 \\
.15 & 26 & 21 & 16 & 8 & 21 & 17 & 12 & 6 & 17 & 13 & 9 & 3 \\
.18 & 18 & 15 & 11 & 6 & 15 & 12 & 9 & 4 & 12 & 9 & 6 & 3 \\
.20 & 15 & 12 & 9 & 5 & 12 & 10 & 7 & 3 & 10 & 7 & 5 & 2 \\
.22 & 12 & 10 & 8 & 4 & 10 & 8 & 6 & 3 & 8 & 6 & 4 & 2 \\
.25 & 10 & 8 & 6 & 3 & 8 & 6 & 5 & 2 & 6 & 5 & 3 & 2 \\
.30 & 7 & 6 & 4 & 2 & 6 & 5 & 3 & 2 & 5 & 3 & 3 & 1 \\
\hline
\end{tabular}


Table 22: Continued

CRC PAUEMENTS

CENTER DEFLECTIONS

\begin{tabular}{|c|c|c|c|c|c|c|c|c|c|c|c|c|c|}
\hline $\begin{array}{l}\text { ACCEPTABLE } \\
\text { ERROR (DMD) }\end{array}$ & $\begin{array}{l}\alpha \\
\beta \\
\end{array}$ & .05 & .1 & $\frac{15}{.2}$ & .5 & .05 & $\therefore 1$ & $\frac{1}{.2}$ & .5 & .05 & .1 & .2 & .5 \\
\hline .02 & & 84 & 67 & 50 & 25 & 69 & 54 & 39 & 18 & 54 & 41 & 28 & 11 \\
\hline .03 & & 38 & 30 & 23 & 12 & 31 & 24 & 18 & 8 & 24 & 18 & 13 & 5 \\
\hline .04 & & 21 & 17 & 13 & 7 & 18 & 14 & 10 & 5 & 14 & 11 & 7 & 3 \\
\hline .05 & & 14 & 11 & 8 & 4 & 11 & 9 & 7 & 3 & 9 & 7 & 5 & 2 \\
\hline .06 & & 10 & 8 & 6 & 3 & 8 & G & 5 & 2 & 6 & 5 & 3 & 2 \\
\hline .07 & & 7 & 6 & 4 & 2 & 6 & 5 & 4 & 2 & 5 & 4 & 3 & 1 \\
\hline .08 & & G & 5 & 4 & 2 & 5 & 4 & 3 & 1 & 4 & 3 & 2 & 1 \\
\hline .09 & & 5 & 4 & 3 & 2 & 4 & 3 & 2 & 1 & 3 & 2 & 2 & 1 \\
\hline .10 & & 4 & 3 & 2 & 1 & 3 & 3 & 2 & 1 & 3 & 2 & 1 & 1 \\
\hline .12 & & 3 & 2 & 2 & 1 & 2 & 2 & 1 & 1 & 2 & $\tilde{E}$ & 1 & 1 \\
\hline
\end{tabular}

CRC PAUEMENTS

EDGE DEFLECTIONS

\begin{tabular}{|c|c|c|c|c|c|c|c|c|c|c|c|c|c|}
\hline \multirow{2}{*}{$\begin{array}{l}\text { ACCEPTABLE } \\
\text { ERROR (DMD) }\end{array}$} & \multirow{2}{*}{$\stackrel{\alpha}{\beta}$} & \multicolumn{4}{|c|}{-.05} & \multicolumn{4}{|c|}{1} & \multicolumn{4}{|c|}{.2} \\
\hline & & .05 & .1 & .2 & .5 & .05 & .1 & .2 & .5 & .05 & .1 & .2 & .5 \\
\hline .02 & & 652 & 531 & 396 & 199 & 543 & 424 & 305 & 136 & 424 & 320 & 218 & 80 \\
\hline .03 & & 295 & 236 & 176 & 89 & 241 & 189 & 136 & 61 & 189 & 143 & 97 & 36 \\
\hline .04 & & 168 & 133 & 99 & 50 & 136 & 106 & 77 & 34 & 106 & 80 & 55 & 20 \\
\hline .05 & & 105 & 85 & 64 & 32 & 87 & 68 & 49 & 22 & 68 & 52 & 35 & 13 \\
\hline .06 & & 74 & 59 & 44 & 22 & 61 & 47 & 34 & 15 & 47 & 36 & 25 & 9 \\
\hline .07 & & 54 & 44 & 33 & 17 & 45 & 35 & 25 & 11 & 35 & 27 & 18 & $?$ \\
\hline .08 & & 42 & 34 & 25 & 13 & 34 & 27 & 19 & 9 & 27 & 20 & 14 & 5 \\
\hline .09 & & 33 & 27 & 20 & 10 & 27 & 21 & 15 & 7 & 21 & 16 & 11 & 4 \\
\hline .10 & & 27 & 22 & 16 & 8 & 22 & 17 & 13 & G & 17 & 13 & 9 & 4 \\
\hline .12 & & 19 & 15 & 11 & 6 & 15 & 12 & 9 & 4 & 12 & 9 & 6 & 3 \\
\hline
\end{tabular}




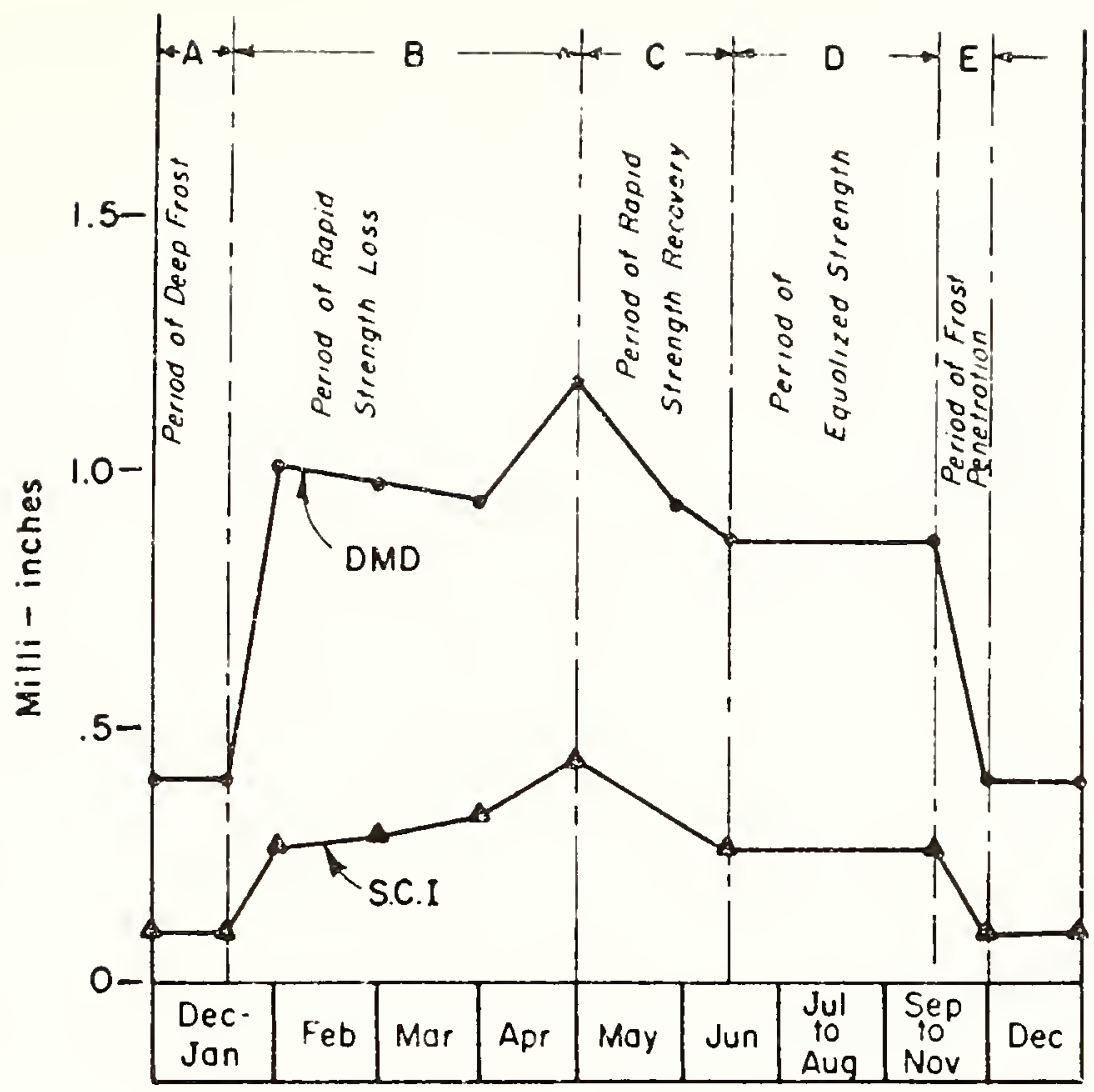

Figure 28: Typical Yearly Fluctuations of DMD and SCI for Flexible Pavements (From Peterson et al.) 
have more time to measure deflections and could manage with a fewer number of Dynaflects and trained personnel.

Approach to the Development of Estimation Models

Deflection values of 41 pavements were determined during the fall of 1977 and spring of 1978. Thirteen of these were flexible, 13 were overlay, 10 were JRC and 5 were CRC pavements. Based on these data, estimation models for each of the four pavement types have been developed and are given in Table 23. The following relations were attempted for each pavement type:

1. Estimates of center of lane spring deflection parameters from center of lane fall deflection parameters.

2. Estimates of edge spring deflection parameters from edge fall deflection parameters.

3. Estimates of edge spring deflection parameters from center of lane fall deflection parameters. These models would be specially useful as the center of lane deflections are in some cases most convenient to measure.

Since the variances of data were not homogenous, necessary transformations of variables, as seen in the models, were done to make the variances homogenous.

General comments on these models are given below: Flexible Pavements. The models, in general, showed reasonable $R^{2}$ and MSE and those which are significant can be used for estimation purposes. The spring SCI has no significant correlation with fall SCI and cannot be estimated. 
Table 23: Models Relating Fall and Spring Deflection Parameters

\begin{tabular}{|c|c|c|c|c|c|c|}
\hline $\begin{array}{c}\text { MODEL } \\
\text { NO. }\end{array}$ & & DESCRIPTIDN OF MODEL $\neq$ & $\begin{array}{l}\text { MULT } \\
\text { CORR. } \\
\text { COEFF } \\
\left(R^{2}\right)\end{array}$ & $\begin{array}{l}\text { MEAN. } \\
\text { SOURE } \\
\text { ERROR } \\
\text { (MSE) }\end{array}$ & $\begin{array}{l}\text { LEUEL } \\
\text { OF } \\
\text { SIGNI } \\
(\alpha)\end{array}$ & \\
\hline & & FLEXIBLE PAUEMENTS & & & & \\
\hline (1) & $1 / \operatorname{DMD}(S, C)$ & $=0.1052+0.5714(1 / \operatorname{DMD}(F, C))$ & .474 & 0.023 & .009 & *** \\
\hline (2) & $1 / \mathrm{BCI}(5, \mathrm{C})$ & $=1.1816+0.6250(1 / \mathrm{BCI}(F, C))$ & .712 & 4.298 & .000 & $* * *$ \\
\hline (3) & $1 / \mathrm{SCI}(\mathrm{S}, \mathrm{C})$ & $=1.2061+0.1748(1 / \operatorname{SCI}(F, C))$ & .125 & 0.582 & .237 & NSR \\
\hline (4) & $1, \operatorname{SPD}(S, C)$ & $=-0.0047+1.3362(1 / \operatorname{SPD}(F, C))$ & .509 & 0.000 & .006 & $* * *$ \\
\hline (5) & $1 / D M D(S, E)$ & $=0.1006+0.6208(1 / \operatorname{DMD}(F, E))$ & .505 & 0.028 & .006 & $* * *$ \\
\hline (6) & $1 / \mathrm{BCI}(\mathrm{S}, \mathrm{E})$ & $=0.4184+0.7962(1 / \operatorname{BCI}(F, E))$ & .829 & 2.217 & .000 & *** \\
\hline (7) & $1 / S C I(S, E)$ & $=1.1098+0.2170(1 / \operatorname{SCI}(F, E))$ & .136 & 0.726 & .215 & NSR \\
\hline$(8)$ & $1 / \operatorname{SPD}(S, E)$ & $=-0.0029+1.2212(1 / \operatorname{SPD}(F, E))$ & .521 & 0.000 & .005 & *** \\
\hline$(9)$ & $1 / \operatorname{DMD}(S, E)$ & $=0.0846+0.5838(1 / \operatorname{DMD}(F, C))$ & .486 & 0.029 & .008 & $* * *$ \\
\hline$(10)$ & $1 / \operatorname{BCI}(S, E)$ & $=1.2882+0.6092(1 / \mathrm{BCI}(F, C))$ & .779 & 2.858 & .000 & $* * *$ \\
\hline (11) & $1 / \operatorname{SCI}(S, E)$ & $=1.2165+0.1520(1 / \operatorname{SCI}(F, C))$ & .074 & 0.778 & .367 & NSR \\
\hline$(12)$ & $1 / \operatorname{SPD}(S, E)$ & $=-0.0052+1.3788(1 / \operatorname{SPD}(F, C))$ & .477 & 0.000 & .009 & $* * *$ \\
\hline
\end{tabular}

OUERLAY PAUEMENTS

\begin{tabular}{|c|c|c|c|c|c|c|c|}
\hline (13) & $\operatorname{LOG}(\operatorname{DMD}(S, C))$ & $=0.0750$ & $+0.6882 \operatorname{LOG}(\operatorname{DMD}(F, C))$ & .644 & 0.008 & .002 & $* * *$ \\
\hline (14) & $\operatorname{LOG}(B C I(S, C))$ & $=0.0466$ & $+0.9111 \operatorname{LOG}(\mathrm{BCI}(\mathrm{F}, \mathrm{C}))$ & .712 & 0.009 & .001 & *** \\
\hline (15) & $\operatorname{LOG}(S C I(S, C))$ & $=0.0626$ & $+0.9431 \operatorname{LOG}(\operatorname{SCI}(F, C))$ & .569 & 0.043 & .005 & $* * *$ \\
\hline (16) & $\operatorname{LOG}(\operatorname{SPD}(S, C))$ & $=-.5676$ & $+1.3069 \mathrm{LOG}(\mathrm{SPD}$ & .754 & 0.001 & .000 & $* * *$ \\
\hline (17) & $\operatorname{LOG}(\operatorname{DMD}(S, E))$ & $=0.0619$ & $+0.6718 \mathrm{LOC}(\mathrm{D} / \mathrm{D}(F, E))$ & .719 & 0.006 & .000 & $* * *$ \\
\hline (18) & $\operatorname{LOG}(B C I(S, E))$ & $=0.1086$ & $+0.9623 \operatorname{LOG}(B C I(F, E))$ & .591 & 0.016 & .003 & $* * *$ \\
\hline (19) & $\operatorname{LOG}(\operatorname{SCI}(S, E))$ & $=-.0207$ & $+0.8890 \operatorname{LOG}(\operatorname{SCI}(F, E))$ & .574 & 0.042 & .004 & $* * *$ \\
\hline$(20)$ & $\operatorname{LOG}(\operatorname{SPD}(S, E))$ & $=-.2990$ & $+1.1646 \operatorname{LOG}(\operatorname{SPD}(F, E))$ & .763 & 0.001 & .000 & $* * *$ \\
\hline (21) & $\operatorname{LCG}(\operatorname{DMD}(S, E))$ & $=0.1072$ & $+0.6824 \operatorname{LOG}(\operatorname{DMD}(F, C))$ & .672 & 0.007 & .001 & $* * *$ \\
\hline (22) & $\operatorname{LDG}(\operatorname{BCI}(S, E))$ & $=0.1643$ & $+0.9494 \operatorname{LOG}(B C I(F, C))$ & .616 & 0.015 & .003 & $* * *$ \\
\hline (23) & $\operatorname{LOG}(\operatorname{SCI}(S, E))$ & $=0.1614$ & $+0.9709 \operatorname{LOG}(\operatorname{SCI}(F, C))$ & .611 & 0.038 & .003 & $* * *$ \\
\hline (24) & $\operatorname{LOG}(\operatorname{SPD}(S, E))$ & $=-.8082$ & $+1.4362 \operatorname{LOG}(\operatorname{SPD}(F, C))$ & .812 & 0.001 & .000 & $* * *$ \\
\hline
\end{tabular}

* significant at . 10 level

* * Significaryt at .05 LEVEL

* * SIGNIFICANT AT .01 LEUEL

NSR NO SIGNIFICANT RELATIONSHIP $\not S=$ SPRING, $\quad F=$ FALL

$E=E D G E \quad C=$ CENTER

$\operatorname{DMD}(S, C)=$ SPRING DMD RT CENTER

$\operatorname{BCI}(F, E)=F A L L$ BCI $A T \operatorname{EDCE}$ 
Table 23: Continued

\begin{tabular}{|c|c|c|c|c|c|c|}
\hline $\begin{array}{c}\text { MODEL } \\
\text { NO. }\end{array}$ & & DESCRIPTION OF MODEL $\neq$ & $\begin{array}{l}\text { MULT. } \\
\text { CORR. } \\
\text { COEFF } \\
\left(R^{2}\right)\end{array}$ & $\begin{array}{l}\text { MEAN. } \\
\text { SOURE } \\
\text { ERROR } \\
\text { (MSE) }\end{array}$ & $\begin{array}{l}\text { LEUEL } \\
\text { OF } \\
\text { SIGNI } \\
(\alpha)\end{array}$ & \\
\hline & & JRC PAUEMENTS & & & & \\
\hline (25) & $\operatorname{DMD}(S, C)$ & $=0.2462+0.7661 D M D(F, C)$ & .652 & 0.006 & .005 & $* * *$ \\
\hline (26) & $B C I(S, C)$ & $=-0.0586+2.0264 \mathrm{BCI}(\mathrm{F}, \mathrm{C})$ & .775 & 0.001 & .001 & *** \\
\hline (27) & $\operatorname{SCI}(S, C)$ & $=0.0136+0.7160 \operatorname{SCI}(F, C)$ & .381 & 0.000 & .057 & * \\
\hline (28) & $\operatorname{SPD}(S, C)$ & $=E 6.6445+0.1814 \mathrm{SPD}(\mathrm{F}, \mathrm{C})$ & .098 & 5.328 & .378 & NSR \\
\hline (29) & $\operatorname{DMD}(S, E)$ & $=0.3079+0.6295 \mathrm{DMD}(F, E)$ & .627 & 0.006 & .006 & $* *$ \\
\hline$(30)$ & $B C I(S, E)$ & $=-0.0557+1.7528 \mathrm{BCI}(F, E)$ & .762 & 0.001 & .001 & *** \\
\hline (31) & $\operatorname{SCI}(S, E)$ & $=0.0359+0.0211 \mathrm{SCI}(\mathrm{F}, \mathrm{E})$ & .001 & 0.000 & .930 & NSR \\
\hline (32) & $\operatorname{SPD}(S, E)$ & $=18.4835+0.7787 \mathrm{SPD}(\mathrm{F}, \mathrm{E})$ & $.163:$ & 35.123 & .247 & NSR \\
\hline (33) & $\operatorname{DMD}(S, E)$ & $=0.3014+0.7022 \operatorname{DMD}(F, C)$ & .596 & 0.007 & .009 & *** \\
\hline (34) & $B C I(S, E)$ & $=-0.0510+1.9840 \mathrm{BCI}(\mathrm{F}, \mathrm{C})$ & .761 & 0.001 & .001 & $* * *$ \\
\hline (35) & $\operatorname{SCI}(S, E)$ & $=0.0088+0.7862 \operatorname{SCI}(F, C)$ & .452 & 0.000 & .033 & ** \\
\hline (36) & $\operatorname{SPD}(S, E)$ & $=33.4290+0.5828 \operatorname{SPD}(F, C)$ & .1433 & 35.978 & .282 & NSR \\
\hline
\end{tabular}

CRC PAUAMENTS

\begin{tabular}{|c|c|c|c|c|c|c|}
\hline (37) & $\sqrt{\operatorname{DMD}(S, C)}$ & $=0.6831+0.0601 \sqrt{\operatorname{Di1D(F,C)}}$ & .027 & 0.001 & .791 & NSR \\
\hline (38) & $\sqrt{\operatorname{BCI}(\mathrm{S}, \mathrm{C})}$ & $=0.2264+0.1527 \sqrt{B C I(F, C)}$ & .036 & 0.001 & .759 & NSR \\
\hline (39) & $\sqrt{\operatorname{SCI}(S, C)}$ & $=0.0249+0.8451 \sqrt{\operatorname{SCI}(F, C)}$ & .518 & 0.000 & .170 & NSR \\
\hline$(40)$ & $\sqrt{\operatorname{SPD}(S, C)}$ & $=-0.6015+1.1053 \sqrt{\mathrm{SPD}(\mathrm{F}, \mathrm{C})}$ & .670 & 0.006 & .090 & * \\
\hline (41) & $\sqrt{\operatorname{DMD}(S, E)}$ & $=0.5846+0.2373 \sqrt{D M D(F, E)}$ & .558 & 0.001 & .147 & NSR \\
\hline (42) & $\sqrt{B C I(S, E)}$ & $=0.3098-0.1282 \sqrt{B C 1(\bar{F}, E)}$ & .202 & 0.000 & .448 & NSR \\
\hline (43) & $\sqrt{\operatorname{SCI}(S, E)}$ & $=0.1966+0.0120 \sqrt{\operatorname{SCI}(F, E)}$ & .001 & 0.000 & .968 & NSR \\
\hline (44) & $\sqrt{\operatorname{SPD}(S, E)}$ & $=1.7396+0.8307 \sqrt{\mathrm{SPD}(\mathrm{F}, \mathrm{E})}$ & .486 & 0.006 & .191 & NSR \\
\hline (45) & $\sqrt{\operatorname{DMD}(S, E)}$ & $=0.5826+0.2582 \sqrt{\mathrm{DMD(F,C)}}$ & .459 & 0.001 & .209 & NSR \\
\hline$(46)$ & $\sqrt{B C I(S, E)}$ & $=0.3211-0.1920 \sqrt{\mathrm{BCI}(\mathrm{F}, \mathrm{C})}$ & .145 & 0.000 & .527 & NSR \\
\hline$(47)$ & $\sqrt{\operatorname{SCI}(S, E)}$ & $=0.0747+0.6367 \sqrt{\mathrm{SCI}(\mathrm{F}, \mathrm{C})}$ & .535 & 0.000 & .160 & NSR \\
\hline$(48)$ & $\sqrt{\operatorname{SPD}(S, E)}$ & $=0.4419+0.9795 \sqrt{S P D(F, C)}$ & .691 & 0.004 & .081 & * \\
\hline
\end{tabular}

* Significant at . 10 level

* Significant at .05 LEUEL

** SIGNIFICANT AT .01 LEUEL

NSR NO SICNIFICANT RELATIONSHIP

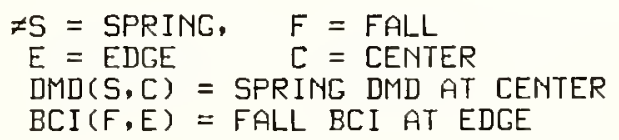


Overlay Pavements. All models are significant with reasonable $R^{2}$ and MSE.

JRC Pavements. Spring spreadability and SCI values have no significant relationship with fall spreadability and SCI values and thus cannot be estimated.

CRC Pavements. None of the three important deflection parameters (DMD, $\mathrm{BCI}$ and SCI) were found to have significant relationship with fall spreadability values and thus cannot be estimated.

The main purpose of these models was to present a conceptional relationship between spring and fall deflection parameters so that further work in this direction could be done to develop more accurate and reliable models. The models were obtained using just one fall and one spring reading, and hence, must be treated accordingly. 
CHAPTER 6: SKID STUDIES

\section{Purpose}

The Indiana State Highway Commission has been measuring skid resistance of its pavements routinely since 1970 using the trailer type skid-tester shown in Figures 29 and 30. Vehicle speed and pavement temperature are recorded during the skid testing. The speed is maintained at $40 \mathrm{mph}$ but minor variations of the order of $\pm 3 \mathrm{mph}$, do occur. Five skid tests are made in each test section and the average of these 5 measurements is taken as the skid resistance of a particular pavement section.

With this background, the primary purpose of this phase was to determine the role skid numbers should play in setting up a rehabilitation program. Secondary purposes of this study were to determine the number of skid tests required per section which could be averaged to have a reliable estimate of the true skid resistance of that section. It was also desired to investigate if pavement temperatures and minor variations in vehicle speeds have any significant effect on the output of skid tester, and to examine if there are definite predictable trends in the decay rates of skid resistance for a particular pavement type - age of surfacing - volume of vehicular traffic - type of surfacing combination. 


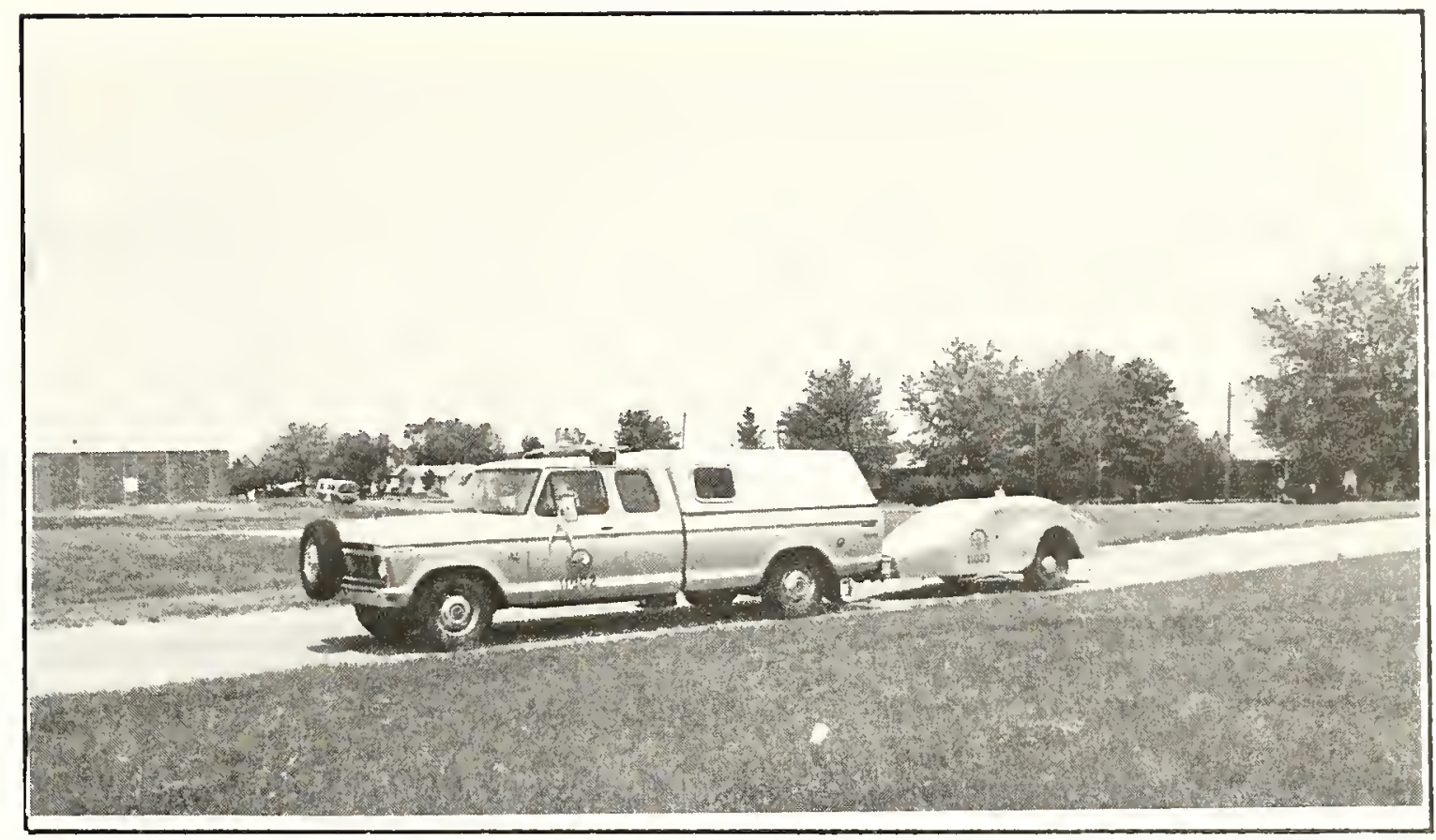

Figure 29: The Indiana State Highway Commission's Skid Tester

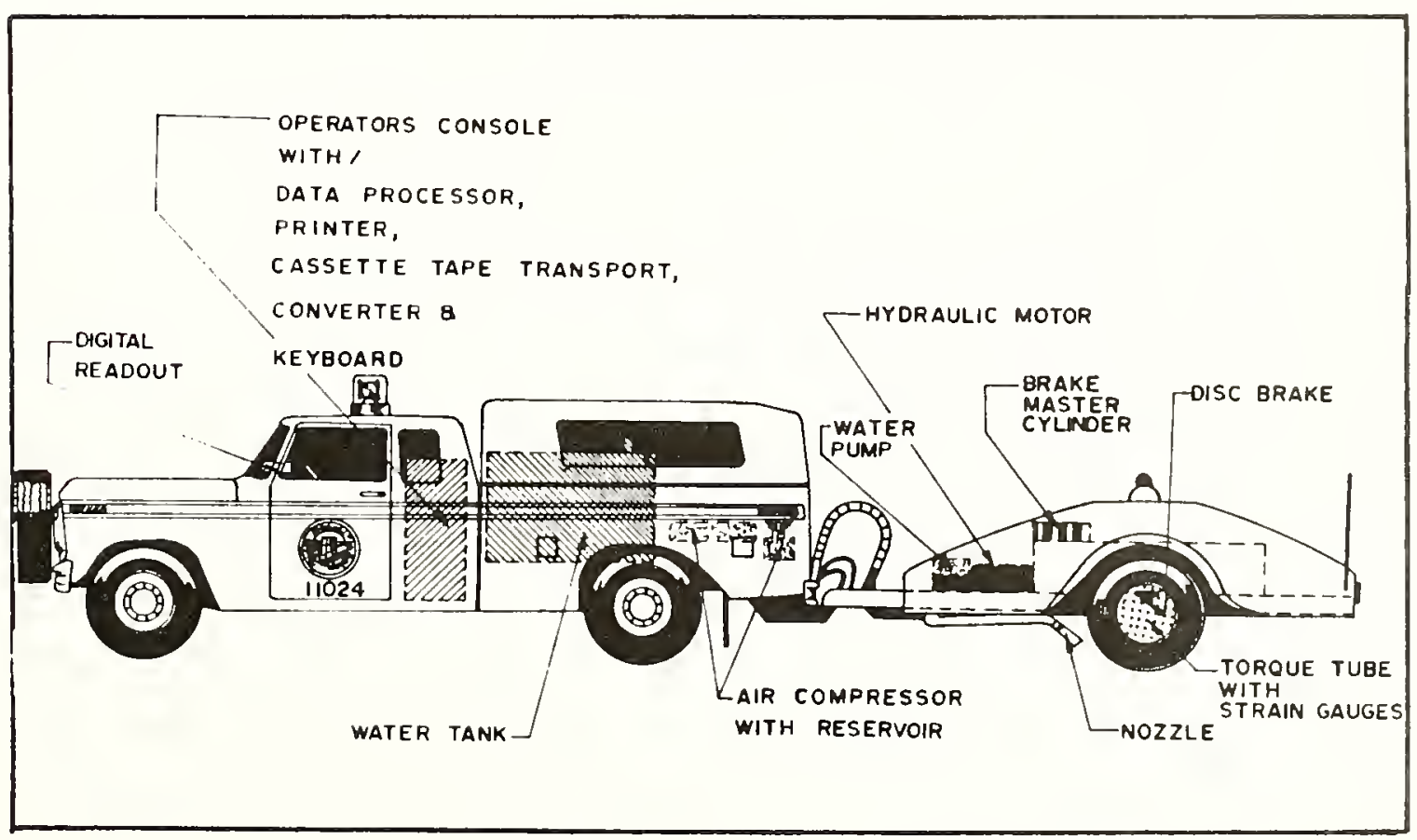

Figure 30: Schematic of the Indiana State Highway Commission's Skid Tester 


\section{Data Collection}

The 46 test sections selected for deflection studies were used as a data base for this phase of the study. Out of these 46 test sections skid measurements could be obtained on only 41 test sections. All of the four pavement types were represented in the study.

A minimum of 5 skid tests were made on each test section. During the fall of 1977 , vehicle speed and pavement temperature was recorded only once for the 5 tests made in each test section, but during the spring of 1978 vehicle speed and pavement temperature was recorded with each test made. Skid measurements were taken in the fall of 1977 and again in the spring of 1978 during about the same period when all other measurements required for this research project were also recorded. The average values of skid numbers for each test section are shown in Table F1 of Appendix F.

\section{Data Analysis}

Number of Skid Tests

Equation (6) developed in Chapter 2, and given below was used to calculate the rumber of skid tests required for estimating the skid resistance of a pavement section,

$$
N=\left[\frac{\left(t_{\alpha}+t_{\beta}\right) \sigma}{c}\right]^{2}
$$

where, $\sigma=$ standard deviation of skid tester, and all other symbols have their meaning as given earlier.

To determine the standard deviation of the Indiana State Highway Commission's skid tester all the test sections were grouped into homogenous categories so that separate computations could be made for each 
group. For this purpose, tests of homogenity of variance were first done on the skid measurements of all test sections within each pavement type. The variances within each pavement type were found homogenous. An attempt for further grouping of pavement types gave the following three groups with homogenous variances:

\section{Group}

1. Flexible Pavements

2. Overlay Pavements

3. JRC and CRC Pavements

\section{Pooled Standard Deviation*}

3.644

3.198

2.997

For a range of 1 to 6 of acceptable error in skid numbers and various type I and type II errors, the number of skid tests required are given in Table 24. The purpose of skid measurements will guide in the selection of particular acceptable error and appropriate levels of type I and type II errors.

Effects of Pavement Temperature and Vehicle Speed

Skid data of spring 1978 was used for this analysis because pavement temperature and vehicle speed was recorded for each skid test made during this period. Three separate analyses were done for the three pavement type groups established earlier on the basis of homogenity of variances of the skid measurements. The following model was tested in each case,

$$
Y=\mu+A_{1}(T \text { Sects })+A_{2}(T)+A_{3}(V)
$$

where, $\quad Y=$ Skid Number as measured

T Sects $=$ Effect of Test Sections 
Table 24: Number of Skid Tests Required per Test Section

FLEXIBLE PAUEMENTS

\begin{tabular}{|c|c|c|c|c|c|c|c|c|c|c|c|c|}
\hline \multirow{2}{*}{$\begin{array}{l}\text { ACCEPTABLE } \\
\text { ERRDR (SN) } \\
\end{array}$} & \multirow{2}{*}{$\alpha .05$} & \multicolumn{3}{|c|}{.05} & \multicolumn{4}{|c|}{1} & \multicolumn{4}{|c|}{2} \\
\hline & & .1 & .2 & .5 & .05 & .1 & .2 & .5 & .05 & .1 & .2 & .5 \\
\hline 1.00 & 242 & 179 & 126 & 61 & 179 & 125 & 82 & 32 & 126 & 82 & 47 & 12 \\
\hline 1.50 & 108 & 80 & 56 & 27 & 80 & 56 & 37 & 14 & 56 & 37 & 21 & 6 \\
\hline 2.00 & 61 & 45 & 32 & 15 & 45 & 32 & 21 & 8 & 32 & 21 & 12 & 3 \\
\hline 2.50 & 39 & 29 & 20 & 10 & 29 & 20 & 13 & 5 & 20 & 13 & 8 & ? \\
\hline 3.00 & 27 & 20 & 14 & 7 & 20 & 14 & 9 & 4 & 14 & 9 & 6 & 2 \\
\hline 3.50 & 20 & 15 & 11 & 5 & 15 & 11 & 7 & 3 & 11 & 7 & 4 & 1 \\
\hline 4.00 & 15 & 12 & 8 & 4 & 12 & 8 & 5 & 2 & 8 & 5 & 3 & 1 \\
\hline 4.50 & 12 & 9 & 7 & 3 & 9 & 7 & 4 & 2 & 7 & 4 & 3 & 1 \\
\hline 5.00 & 10 & 8 & 5 & 3 & 8 & 5 & 4 & 2 & 5 & 4 & 2 & 1 \\
\hline 6.00 & 7 & 5 & 4 & 2 & 5 & 4 & 3 & 1 & 4 & 3 & 2 & 1 \\
\hline
\end{tabular}

OUERLAY PAUEMENTS

\begin{tabular}{|c|c|c|c|c|c|c|c|c|c|c|c|c|}
\hline \multirow{2}{*}{$\begin{array}{l}\text { ACCEPTABLE } \\
\text { ERROR (SN) }\end{array}$} & \multirow{2}{*}{$\alpha \overline{.05}$} & \multicolumn{3}{|c|}{.05} & \multicolumn{4}{|c|}{.1} & \multicolumn{4}{|c|}{.2} \\
\hline & & .1 & .2 & .5 & .05 & .1 & .2 & .5 & .05 & .1 & .2 & .5 \\
\hline 1.00 & 166 & 125 & 88 & 42 & 125 & 90 & 59 & 23 & 88 & 59 & 35 & 9 \\
\hline 1.50 & 84 & 56 & 40 & 19 & 56 & 40 & 26 & 10 & 40 & 26 & 16 & 4 \\
\hline 2.00 & 42 & 32 & 22 & 11 & 32 & 23 & 15 & 6 & 22 & 15 & 9 & 3 \\
\hline 2.50 & 27 & 20 & 14 & 7 & 20 & 15 & 10 & 4 & 14 & 10 & 6 & 2 \\
\hline 3.00 & 19 & 14 & 10 & 5 & 14 & 10 & 7 & 3 & 10 & 7 & 4 & 1 \\
\hline 3.50 & 14 & 11 & 8 & 4 & 11 & 8 & 5 & 2 & 8 & 5 & 3 & 1 \\
\hline 4.00 & 11 & 8 & 6 & 3 & 8 & 6 & 4 & 2 & 6 & 4 & 3 & 1 \\
\hline 4.50 & 9 & 7 & 5 & 2 & 7 & 5 & 3 & 2 & 5 & 3 & 2 & 1 \\
\hline 5.00 & 7 & 5 & 4 & 2 & 5 & 4 & 3 & 1 & 4 & 3 & 2 & 1 \\
\hline 6.00 & 5 & 4 & 3 & 2 & 4 & 3 & 2 & 1 & 3 & 2 & 1 & 1 \\
\hline
\end{tabular}


Table 24: Continued

JRC PAUEMENTS

CRC PAUEMENTS

\begin{tabular}{|c|c|c|c|c|c|c|c|c|c|c|c|c|}
\hline \multirow{2}{*}{$\begin{array}{l}\text { ACCEPTABLE } \\
\text { ERROR (SN) }\end{array}$} & \multicolumn{4}{|c|}{$\ldots .05$} & \multicolumn{4}{|c|}{.1} & \multicolumn{4}{|c|}{.2} \\
\hline & $B . \overline{.05}$ & .1 & .2 & .5 & .05 & .1 & .2 & .5 & .05 & .1 & .2 & .5 \\
\hline 1.00 & 136 & 103 & 73 & 34 & 103 & 75 & 50 & 19 & 73 & 50 & 30 & 8 \\
\hline 1.50 & 61 & 46 & 33 & 15 & 46 & 34 & 22 & 9 & 33 & 22 & 14 & 4 \\
\hline 2.00 & 34 & 26 & 19 & 9 & 26 & 19 & 13 & 5 & 19 & 13 & 8 & 2 \\
\hline 2.50 & 22 & 17 & 12 & 6 & 17 & 12 & 8 & 3 & 12 & 8 & 5 & 2 \\
\hline 3.00 & 15 & 12 & 9 & 4 & 12 & 9 & 6 & 2 & 9 & 6 & 4 & 1 \\
\hline 3.50 & 11 & 9 & 6 & 3 & 9 & 6 & 4 & 2 & 6 & 4 & 3 & 1 \\
\hline 4.00 & 9 & 7 & 5 & 3 & 7 & 5 & 3 & 2 & 5 & 3 & 2 & 1 \\
\hline 4.50 & 7 & 5 & 4 & 2 & 5 & 4 & 3 & 1 & 4 & 3 & 2 & 1 \\
\hline 5.00 & 6 & 5 & 3 & 2 & 5 & 3 & 2 & 1 & 3 & 2 & 2 & 1 \\
\hline 6.00 & 4 & 3 & 2 & 1 & 3 & 2 & 2 & 1 & 2 & 2 & 1 & 1 \\
\hline
\end{tabular}




$$
\begin{aligned}
& T=\text { Effect of Pavement Temperature } \\
& V=\text { Effect of Vehicle Speed. }
\end{aligned}
$$

The factor 'T Sects' was used as a dummy variable and was forced at the first step in the regression analysis so as to remove its effect from the skid measurements. One degree and two degree terms of 'pavement temperature' and 'vehicle speed' and their interaction term were then entered in a stepwise manner wherein the variable with the highest simple correlation coefficient with the residuals from the previous step is entered next. Results of regression analyses are summarized in Table 25.

\begin{tabular}{|c|c|c|c|c|c|c|}
\hline \multirow[b]{2}{*}{ UARIABLE } & \multicolumn{2}{|c|}{ FLEXIBLE PAUEMENTS } & \multicolumn{2}{|c|}{ OUERLAY PAUEMENTS } & \multicolumn{2}{|c|}{ JRC AND CRC PAUEMENTS } \\
\hline & $\begin{array}{l}\text { LEUEL OF } \\
\text { SIGNIF ICANCE }\end{array}$ & $R^{2}$ & $\begin{array}{l}\text { LEUEL OF } \\
\text { SIGNIFICANCE }\end{array}$ & $R^{2}$ & $\begin{array}{l}\text { LEUEL OF } \\
\text { SIGNIF ICANCE }\end{array}$ & $R^{2}$ \\
\hline TSECTS & .000 & .798 & .000 & .940 & .000 & .905 \\
\hline TEMP & .718 & & .242 & & .407 & \\
\hline SQTEMP & .190 & & .365 & & .362 & \\
\hline SPEED & .356 & & .553 & & $.026 * *$ & \\
\hline SOSPEED & .824 & & .511 & & .964 & \\
\hline SPDXTEMP & .245 & .816 & .123 & .944 & .332 & .912 \\
\hline
\end{tabular}

Table 25: Summary of Regression Analysis Results 
As will be seen from Table 25, the various analyses done on skid data concluded the following:

1. Pavement temperature differential (Pavement Temperature minus $80^{\circ} \mathrm{F}$ ) had no significant effect on the skid measurements for any of the 4 pavement types. In the spring season skid measurements on which this analysis was made, pavement temeratures ranged from $78^{\circ} \mathrm{F}$ to $105^{\circ} \mathrm{F}$ and therefore the results of this analysis are valid for this range only.

2. Vehicle speed differential (Vehicle speed - $40 \mathrm{mph}$ ) had a significant effect on the skid measurements of JRC and CRC pavements only and not on the skid measurements of flexible and overlay pavements. Again, the data analyzed in this study had vehicle speeds from $37.7 \mathrm{mph}$ to $40.8 \mathrm{mph}$ and therefore this analysis is valid for this range only. A coefficient of -1.2257 was found for this factor. That means that for every $1 \mathrm{mph}$ speed above $40 \mathrm{mph}, 1.23$ should be added to the measured skid number, and vice-versa. The effect of minor variations in speed is shown in Figure 31 for convenient use.

\section{Trends in Decay of Skid Resistance}

An attempt was made using fall 1977 and spring 1978 skid measurements of the 41 test sections to examine if any definite trends in the decay rates of skid resistance exist for different pavement types. The fall 1977 and the spring 1978 skid data of the 41 test sections are plotted in Figure 32. The plots showed that skid resistance of 25 out of 41 of of the pavement sections improved in spring 1978 as compared to their 


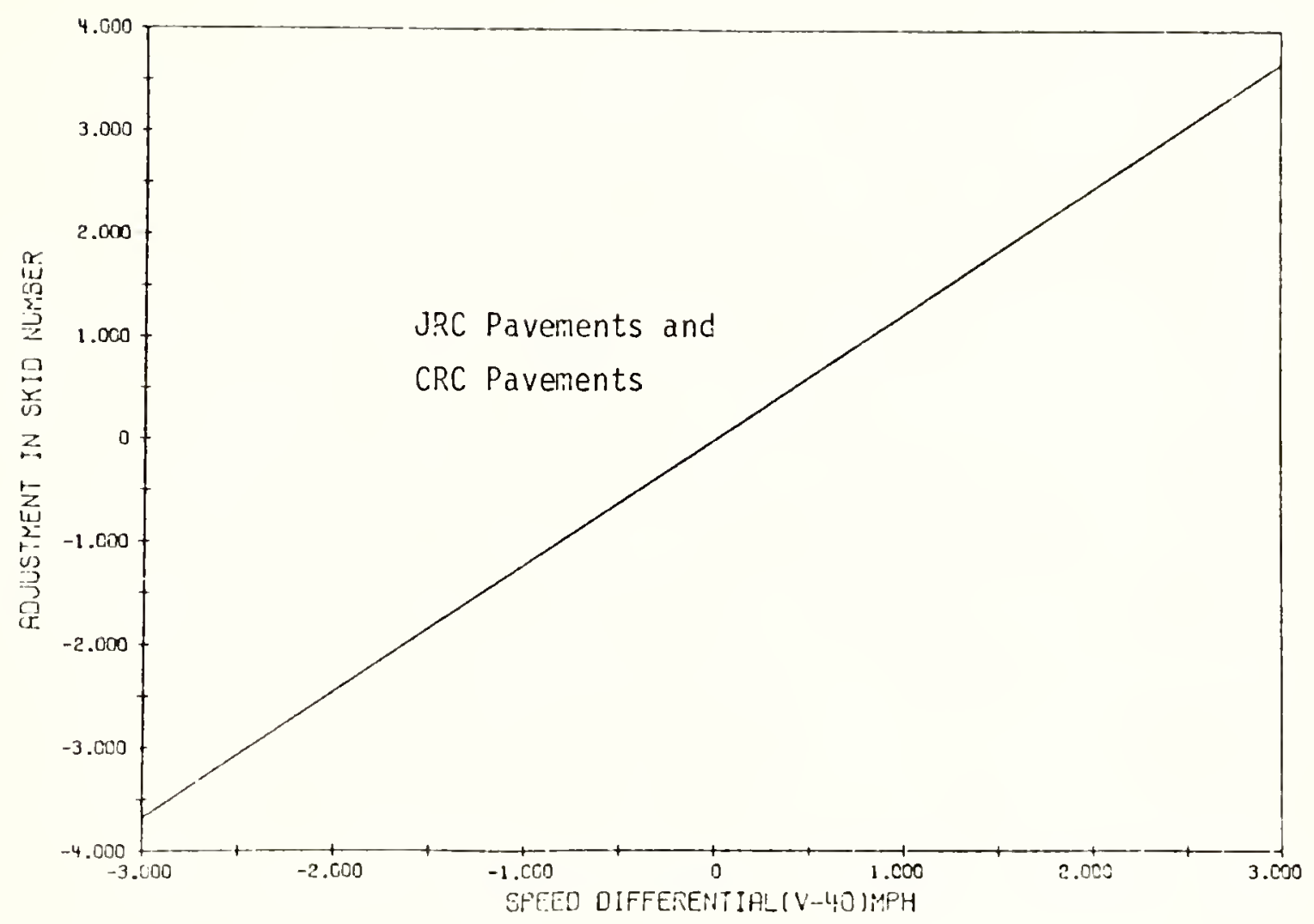

Figure 31: Effect of Vehicle Speed on the Skid Resistance 


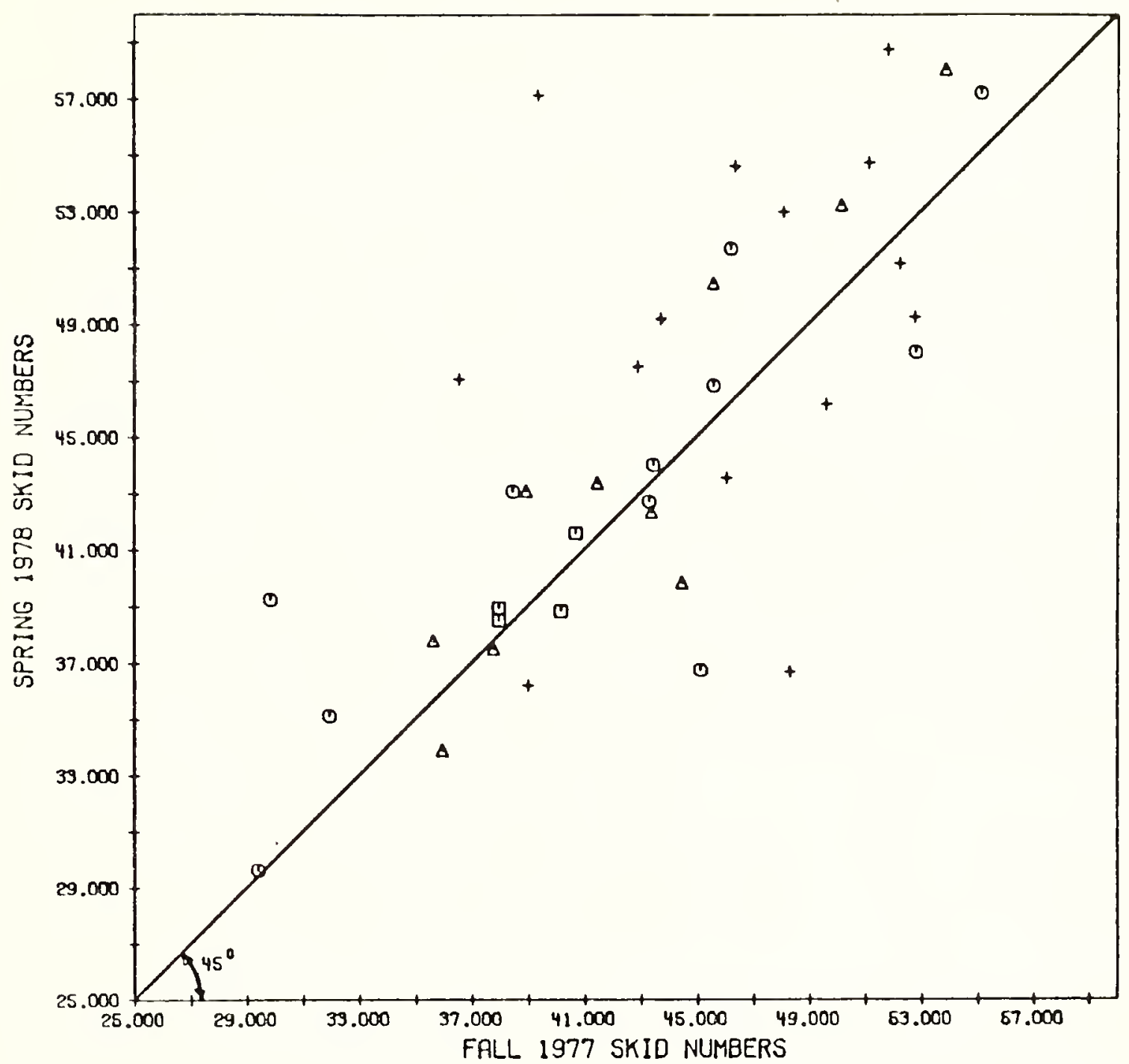

\section{Legend}

- Flexible Pavements

+ Overlay Pavements

$\triangle \quad$ JRC Pavements

o CRC Pavements

Figure 32: Relationship Between Fall 1977 and Spring 1978 Skid Numbers. 
skid resistance in fall 1977 . These results agree with similar other studies done in the past.

\section{Summary}

1. For an acceptable error in skid number of 2 and a significance level of 0.1 , eight skid tests are required on flexible pavements, six on overlay pavements and five on JRC and CRC pavements. For different accuracy and different significance levels, the number of skid tests required are given in Table 24.

2. Pavement temperatures (in the range of $78^{\circ}$ to $105^{\circ} \mathrm{F}$ ) had no apparent effect on the skid measurements.

3. Even minor variations in vehicle speeds had a significant effect on the skid measurements of JRC and CRC pavements and for a differential of $\pm 3 \mathrm{mph}$ from $40 \mathrm{mph}$ the effect was 1inear. Every $1 \mathrm{mph}$ increase in speed above $40 \mathrm{mph}$ underreads the skid number by 1.23. The effect of vehicle speeds on skid numbers is shown in Figure 31. Minor variations in vehicle speeds had no effect on the skid measurements of flexible and overlay pavements.

4. Skid resistance of pavements of all types varies with seasons.

5. It is not possible to determine short term (1ess than one year) decay rates of skid resistance of pavements. 
CHAPTER 7: RECOMMENDATIONS FOR DEVELOPING A PAVEMENT EVALUATION SYSTEM

\section{General Framework}

This chapter details general outlines which can be used as basis for setting up a pavement evaluation system at the state level.

Highway departments have persistent use for a pavement evaluation system at two levels (26):

1. Total highway network level

2. Individual project level

Both systems have about the same conceptual approach but the degree of accuracy, frequency of measurements and the depth of detail are different for the two levels.

Pavement Evaluation at the Total Network Level

A pavement evaluation system at the total network level has two main functions,

1. Statewide financial planning and priority programming of major maintenance of pavement systems in the long run as well as in the short run.

2. Identification of deficient pavement sections which require detailed evaluation.

For performing the above two functions, the pavement evaluation system at the total network level need not be very precise. However, it should be continuous and capable of considering a large mileage of pavements at the same time. This requirement has led to the use of machines to measure pavement performance and use of computer for storing and handling the data. 
The basic approach in setting up such a system involves use of indicators (i.e., roughness) of pavement performance and a determination of minimum desirable levels of each of the indicators. A continuous monitoring of an entire network permits a check on the performance levels of each indicator and lists those pavements which are below standard.

However, the cost of continuous monitoring may be huge and may not always be justifiable. To reduce costs, pavement performance history curves may be developed for various homogenous groups of pavements using data collected over a span of several years and based on the trends computed over these years it is possible to develop models which predict pavement performance and/or decay rates of various indicators of pavement performance. These models can then be used to monitor performance levels of pavements. These models must be checked regularly and validated.

The pavement properties which can be objectively measured using machines and which have been used as pavement evaluation criteria include (1):

1. Pavement Serviceability as measured by roughness.

2. Structural Adequacy

3. Skid Resistance

4. Distress Manifestations.

The minimum desirable level of each of these criteria need to be established as a first step. These minimum levels are based on subjective judgments and previous performance histories by other agencies. These levels can then be updated as the system development progresses. 
Pavement Evaluation at the Project Level

After the system has listed deficient segments of the network, a more thorough evaluation is required to assess the needs of these segments and to devise optimal methods of rehaibilitation. This micro level process requires more precision, and since it is small in size it justifies the attention of experienced engineers. At this level, pavement distress may be more efficiently measured manually while more expeditious methods like photologging may be better at the network level.

\section{Procedure Outline}

Although pavement evaluation is a continuous activity, considerably more effort is needed in the initial stages of development. After a system is set up and validated, only a fraction of the initial effort is required to keep the system operational and at the same time permitting changes to be made in the system as necessary. In the context of the state of Indiana, the following outline of a pavement evaluation system, consisting of 9 steps is recommended:

1. Prepare complete inventory of existing pavements.

2. Group the pavements into homogenous categories.

3. Establish, on a statistical basis, control sections for continuous monitoring.

4. Establish standard conditions for operating pavement evaluation equipment.

5. Measure pavement performance of the control sections periodicaliy.

6. Establish performance history curves for each homogenous group of pavements and compute decay rates. 
7. Decide on minimum acceptable levels of pavement performance criteria.

8. Establish optimal routine maintenance methods.

9. Establish overlay design procedure.

Necessary details of each of the 9 steps outlined above are given in the following sections.

\section{Inventory of Existing Pavements}

An accurate inventory of existing pavements is necessary before a pavement evaluation system is conceived. The following information on existing pavements will be necessary:

1. Cross Section Details
(a) Number of lanes in both directions
(b) Width of pavement
(c) Width and type of shoulder
(d) Whether pavement is primarily in cut or fill
(e) Type and condition of drainage

2. Pavement Structure Details
(a) Type of pavement
(b) Thickness and composition of each layer
(c) Properties of subgrade

3. Vehicular Traffic
(a) Traffic volumes
(b) Truck traffic and equivalent axle loads
(c) Accident data 
4. Climatic Conditions
(a) Annual rainfall
(b) Maximum daily temperature variations
(c) Freezing index

The Indiana State Highway Commission maintains a summary of road life and traffic data of the state highways. Most of the details required for preparing inventory of pavements are therefore available from these records. A contract section having constant pavement width and thickness, etc., may be taken as a unit of length for this purpose.

\section{Grouping Pavements into Homogenous Categories}

After all the pavements are inventoried it becomes necessary to group all pavements having similar properties within each pavement type. Depending on the available range, each relevant property may be broken into 2 or $3 \mathrm{classes}$ as considered appropriate for this purpose. Data appearing in Tables D3 to D7 of Appendix D may be used as guidelines for this.

\section{Establishing Control Sections}

It is suggested that a random sample be drawn from each group formed in step 2. Desirably three and at least two such control sections should be selected from each group. The 94 test sections selected in this study for pavement serviceability studies and the 46 test sections selected for other studies should be given priority in the choice of control sections. A one kilometer long test section should be randomly located within each pavement section for pavement serviceability studies and 0.4 kilometer long section should be randomly located within each 
one kilometer long section for other studies. These control sections should be permanently marked at the site and their location references recorded as in Table $B 1$ of Appendix $B$. All future tests will be made on these control sections and all pavement sections in the state highway network may then be related to one of these control sections for any maintenance procedure, etc.

Standard Conditions for Operating Pavement Evaluation Equipment The four major indicators of pavement performance (1), and the suggested equipment to measure them are given below:

\section{Indicator}

1. Serviceability

2. Structural Adequacy

3. Skid Resistance

4. Distress Manifestation
Suggested Equipment

Road Meter

Dynaflect

Skid Tester

Instrumented Vehicle for Photologging

For any measurements to be comparable they should be reduced to standard values of variables that significantly influence the output of the measuring equipment. Weather conditions and the temporal changes in the mechanical components of the machines are the main variables. Also, the number of tests required to estimate the value of each indicator should be standardized for the measurements to be comparable.

In this study, a detailed analysis was done on the road meter. Standard conditions for operating this instrument were formulated (Appendix $B$ ). Also the number of passes required (Table 9) and the corrections for air temperature (Figure 7) and gas tank level (Figure 7) were derived. 
In this study, distress (cracking, patching, etc.) was measured manually but for large scale measurements on the total network level, photologging is recommended for use.

Measurements of Pavement Performance Characteristics

After the standard conditions for operating pavement evaluation equipment are formulated, the four properties of each pavement section* should be measured. The required number of passes of each machine, as decided in step 4, should be given. Each pavement section should be measured twice successively over a two year span. These measurements will record the initial state of each pavement section.

After the initial measurements are recorded, it will only be necessary to take measurements every other year.

\section{Plotting Pavement Performance Curves}

Continuous measurements of each pavement property for several years permit a plot of pavement performance against time and/or number of axle loads. To develop a complete pavement performance curve may require 10 or more years. However, if 2 or 3 control sections belong to the same group but are at different levels of the pavement performance curve (e.g., at levels A, B, C in Figure 33) less time will be required to plot these curves. The choice of control sections should be done with this task in mind.

Once a complete pavement performance curve is developed for each pavement property, decay rates can be computed for various stages along the curve.

\footnotetext{
* A pavement section is defined as a contract section having constant pavement width, thickness, etc.
} 


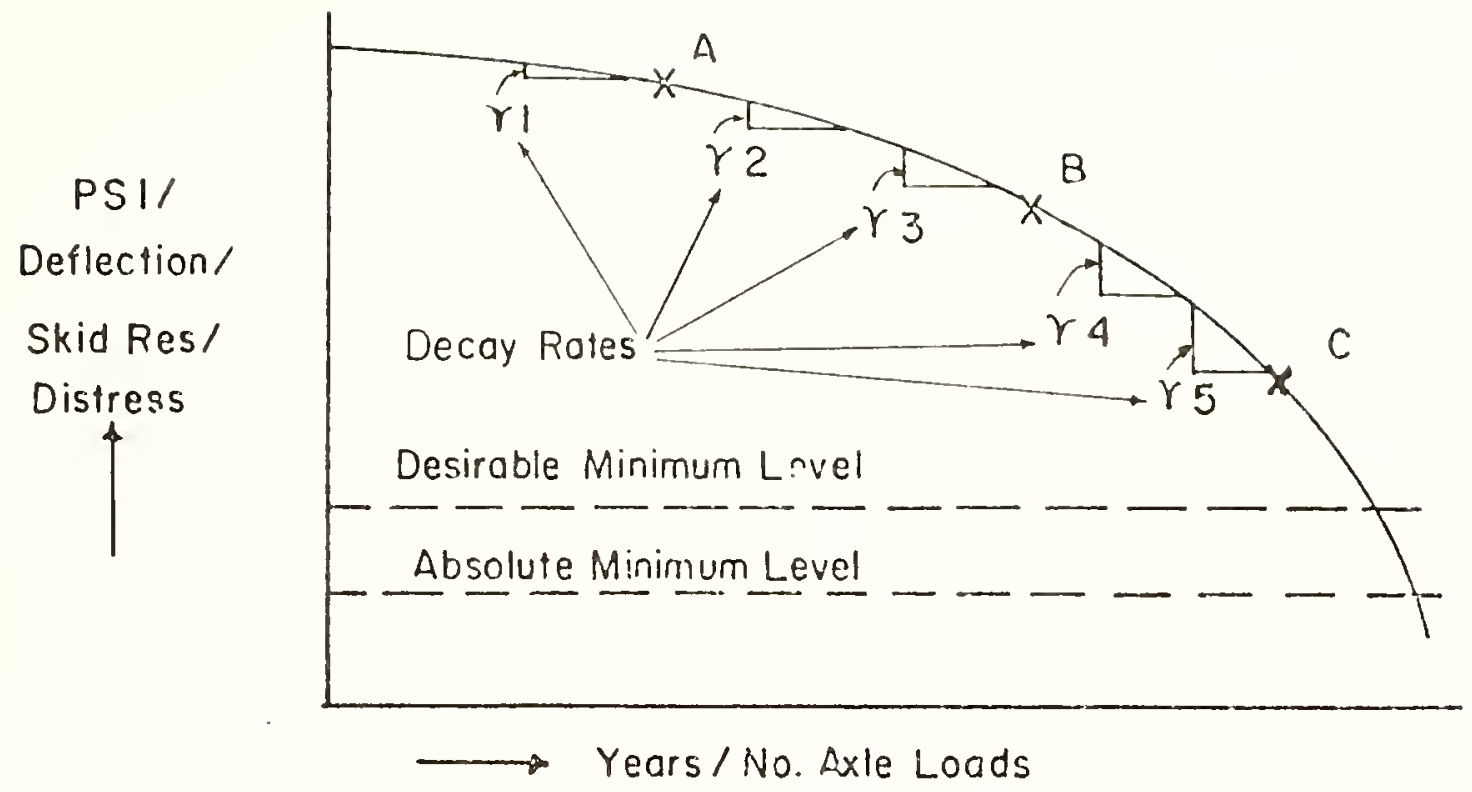

Figure 33: A Typical Pavement Performance Curve

Minimum Acceptable Levels

For any system to operate on a statewide basis, it will be necessary to fix some maintenance criteria, i.e., for example the minimum level of serviceability at which major maintenance is required. Such criteria will be required for deflection, skid resistance and distress as well. To allow flexibility to maintenance planners it is recommended that two minimum levels of each of the four pavement performance characteristics be fixed,

1. Desirable minimum level - at which majority of road users will Tike to see the road improved.

2. Absolute minimum level - below which will be uneconomical (due to high road user costs) and hazardous to drive on the road. 
The process of fixing these levels can be approached in one of the four ways given below:

1. Subjective judgments - as done in this study in the case of pavement serviceability studies.

2. Accident data - in the case of skid resistance where skid accidents are related to slipperiness of the pavement surface.

3. Mathematical computations - the road user costs can be matched with the cost of rehabilitation and an optimal stage computed where both of the costs are equal.

4. Visual inspection of pavement performance curve - the point on the curve where any pavement property drops suddenly.

After these minimum levels are fed into the pavement evaluation system at the total network level, the system will periodically list those pavement sections which are below the desirable minimum levels. Such pavements may then be evaluated at the project level for necessary corrective measures.

\section{Optimal Routine Maintenance Methods}

Decisions on day to day maintenance of pavements such as patching, sealing of cracks and joints and application of thin seal coats are made routinely. Decisions on choice of pavement type, thickness and materials used are based on initial capital cost, cost of overlays and fixed yearly routine maintenance costs. The rate of decay of performance of pavements between two major maintenance operations is usually of no concern. Figure 34 illustrates performance curves for two pavements, $A D B$ and $A C B$, having the same initial PSI and the same upgrading cycle. Even though major maintenance is applied at the same time for both pavements, pavement ACB 


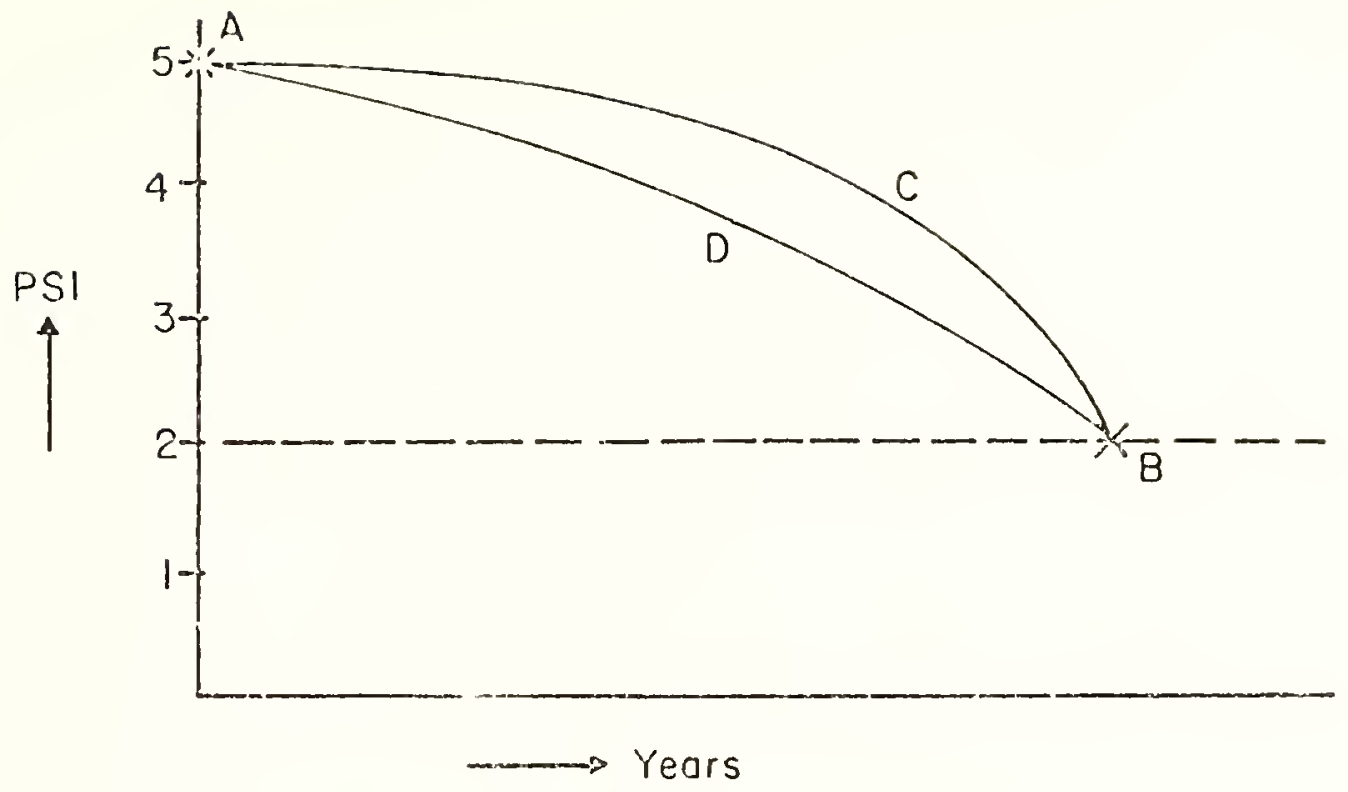

Figure 34: Comparison of Performances of Two Pavements Reaching Terminal Serviceability Level at the Same Time

has given better performance since it had a higher PSR for a longer period of time.

A progressive pavement maintenance management system, while minimizing the costs of routine maintenance, must also optimize routine maintenance methods with a view to provide maximum comfort, convenience and safety to road users. It is, therefore recommended that during the period that pavement performance curves are being plotted as in step 6 , a record should be kept of routine maintenance operations and their costs. A comparative analysis of similar pavements at the end of one maintenance cycle and sometimes at interim stages will reveal the best routine maintenance methods. 
Overlay Design Procedures

Analyses of data collected over a period of several years on the control sections, before and after they are overlaid, will assist in establishing overlay design procedures. Using pavement deflection as a reliable indicator of the structural strength of a pavement, California (9), Utah (33), the FHWA (6) and some other agencies have established overlay design procedures. Using similar approach, design curves usable for the state of Indiana may be drawn. However, before the Dynaflect deflections are used for overlay design, they will have to be adjusted for seasonal variations and corrected to a standard temperature. Unti 1 such time as data specifically for Indiana can be developed, use can be made of criteria already in existence. 


\section{CHAPTER 8: SUMMARY AND CONCLUSIONS}

This study, with an emphasis on the use of pavement evaluation equipment, has presented recommendations for developing a pavement evaluation system in the state of Indiana. Performance evaluation of pavements must be planned as a continuing program. Major findings of this research are summarized in the following paragraphs.

1. This study initially proposed three major criteria of pavement performance:
(a) Serviceability
(b) Structural adequacy
(c) Skid resistance

Another factor 'distress manifestations' was later added as the pavement distress manifestations such as patches, cracks, blow ups and other local failures were not adequately reflected in the PSI models.

In the earlier stages of this research, it was contemplated that these four factors could jointly define the condition of a pavement section at any point in time. Such a function, however, was not established in this phase of the study due to time restraints. This could form the basis of further study in this area.

2. This study made use of the PCA roadmeter possessed by the Indiana State Highway Commission. In the first phase, the various factors 
affecting the output of the roadmeter were examined. The variability of roadmeter was analyzed to determine the number of passes required.

Twenty five test sections each 1 kilometer long, belonging to the four pavement types and all roughness levels, were tested. Three factors air temperature, gas tank level and driver type were found to be significant. Air temperature was found to affect the roadmeter output differentIy for different pavement type - roughness groups. The corrections required to adjust roadmeter measurements to $60^{\circ} \mathrm{F}$ are given in Figure 7 , of Chapter 2.

Gas tank level was found significant only in the case of smooth flexible and smooth overlay pavements. Necessary corrections required to adjust roadmeter measurements to $1 / 2$ full tank are given in Figure 8 of Chapter 2. Driver type was also found significant but since this factor is not easily measurable, this factor was dropped as a requirement in the standard conditions that steady driving be ensured during roadmeter operation.

The following two tasks were also accomplished in this phase:

(i) Standard conditions for operating the roadmeter possessed by the Indiana State Highway Commission were formulated (Appendix B).

(ii) The number of roadmeter passes required to estimate the roughness of a pavement section were computed (Table 9 of Chapter 2).

3. To ensure that the findings of this study have statewide applicability, a random selection of test sections for pavement serviceability studies and other studies was required. For this research, an 
area with its center at West Lafayette and a radius of 70 miles was delineated. Within this area 94 test sections each one kilometer long, and belonging to the 4 pavement types and all roughness groups were randomly selected. These test sections were arranged in five travel loops as shown in Figures $C 1$ to $C 5$ of Appendix C. During this process, a method was developed for coding the whole state highway system, and randomly selecting the test sections having the required properties. Finally, guidelines to organize the randomly selected test sections into travel loops were given.

4. The pavement serviceability studies presented in Chapter 4 were mainly made for the purpose of calibrating the roadmeter measurements against the subjective judgments of road users. A 20 member rating team rated 94 pavements and PSI models were developed for each pavement type. Two forms of PSI models have been developed. Reduced models relate PSI with the roadmeter measurements only and are approximate. These models are given in Equations 10,13,16 and 18; tabulated for convenience in their use (Table 17) and are also graphed as in Figures 20 to 23 . Full models include more variables that influence the opinions of road users and are more accurate. These models are given in Equations 11, 12, 14, 15,17 and 19 .

Finally a procedure has been suggested for checking the accuracy of the roadmeter and recalibrating when necessary.

5. Deflection studies have asserted that edge deflections should be used as design criteria. It was seen that the number of deflection measurements required to estimate the true deflection of a pavement is a function of pavement type and the location of test across the pavement. 
Table 22 has been developed to ascertain the required number of deflection measurements. It has been stated that spring deflections are critical for design but are difficult to measure since the spring thaw period is very short and variable. In this study various models have been developed which permit an estimate of spring deflections from the previous fall deflections. These models were obtained using just one fall and one spring readings, and hence, must be treated accordingly.

6. Skid studies made in this research have given the number of skid tests required to estimate the true skid resistance of a pavement section. Various analyses showed that pavement temperatures (in the range of $78^{\circ}$ to $105^{\circ} \mathrm{F}$ ) had no effect on the skid measurements. Minor variations in vehicle speeds do not effect the skid measurements of flexible and overlay pavements, while minor variations in vehicle speeds have a significant effect on the skid measurements of JRC and CRC pavements. This effect is shown in Figure 31 .

7. Recommendations for developing a pavement evaluation system for Indiana have been given in Chapter 7. The suggested framework of the pavement evaluation system would work at two levels (1) total highway network level and (2) individual project level. The system at the total network level would periodically list pavement sections which are below minimum desirable levels of performance and would be used in statewide financial planning and priority programming of major maintenance. The system at the project level would work on detailed evaluation of deficient sections and prepare designs for overlays, etc.

A nine step procedure has been given for the overall pavement evaluation process. 


\section{LIST OF REFERENCES}




\section{LIST OF REFERENCES}

1. Anderson, D. I., "Improvement of Utah's Flexible Pavement Performance System," Ut,ah DOT, Final Report, March 1976.

2. Anderson, V. L., and McLean, R. A., "Design of Experiments, A Real istic Approach," Marcel Dekker, Inc., New York, 1974.

3. The Asphalt Institute, "Asphalt Overlays and Pavement Rehabilitation," Manual Series No. 17 (MS-17), College Park, Maryland, 1969.

4. The Association of Asphalt Paving Technologists, "Pavement Evaluation," Symposium, Proceedings, Vol. 38, 1969.

5. Austin Research Engineers Inc., "Asphalt Concrete Overlays of Flexible Pavements, Vol. 1. Development of New Design Criteria," Report No. FHWA-RD-75-75, Final Report, June 1975.

6. Austin Research Engineers Inc., "Asphalt Concrete Overlays of Flexible Pavements, Vol. 2. Design Procedures," Report No. FHWARD-75-76, Final Report, June 1975.

7. Bartlett, M. S., "The Use of Transformations," Biometrics, 1947.

8. Belz, Maurice H., "Statistical Methods for the Process Industries," John Wiley \& Sons, New York, 1973.

9. California Division of Highways, Materials and Research Department, "Methods of Test to Determine Overlay and Maintenance Requirements by Pavement Deflection Measurements," Test Method No. Calif. 356-C, October 2, 1972.

10. Carey, W. N. Jr., and Irick, P. E., "The Pavement Serviceability Performance Concept," HRB Bulletin 250, 1960.

11. Chatterjee, S., and Price, B., "Regression Analysis by Example," John Wiley \& Sons, 1977.

12. Chong, G. J., and Stott, G. M., "Evaluation of the Dynaflect and Pavement Design Procedures," Department of Transportation and Communications, Ontario Report No. IR 42, October 1971.

13. Datta, T. K., and Labadie, M. J., "Photologging and Roadway Information System," Paper presented at the 57 th Annual Meeting of TRB, January 1978. 
14. Epps, J. A., et al., "Roadway Maintenance Evaluation User's Manual," Texas Transportation Institute, Research Report 151-2, September 1974.

15. Highway Research Board, "Pavement Performance, Methods for Evaluation," HRB Bulletin 187, 1958.

16. Highway Research Board, "The AASHO Road Test, Report 5, Pavement Research," HRB Special Report 61E, 1962.

17. Highway Research Board, "Highway Capacity Manual," Special Report 87, 1965.

18. Highway Research Board, "Design of Overlays and Pavement Rehabilitation," Record 300, 1969.

19. Highway Research Board, "Pavement Rehabilitation and Design of Overlays," Record 327, 1970.

20. Highway Research Board, "Design and Performance of Rigid and Flexible Pavements," Record 329, 1970.

21. Highway Research Board, "Skid Resistance," NCHRP Synthesis Report No. 14, 1972.

22. Highway Research Board, "Evaluation of Pavement Surface Properties and Vehicle Interactions," Record 471, 1973.

23. Highway Research Board, "Pavement Evaluation Using Road Meters," Special Report 133, 1973.

24. Hocking, R. R., "The Analys is and Selection of Variables in Linear Regression," Biometrics 32, March 1976.

25. House1, W. S., "The Michigan Pavement Performance Study for Design Control and Serviceability Ratings," Proceedings, International Conference on the Structural Design of Asphalt Pavements, University of Michigan, 1962.

26. Hudson, W. R., and Finn, F. N., "A General Framework for Pavement Rehabilitation," TRB Workshop on Pavement Rehabilitation, Proceedings, Report No. FHWA-RD-74-60, June 1974.

27. Indiana State Highway Commission, "Manual of Instructions for Determining State Highway Needs, "November 1968.

28. Indiana State Highway Commission, "Inventory of Bridges," 1975.

29. Lindsey, Alton A., "Natural Features of Indiana," Indiana Academy of Science, Indianapolis, July 1966. 
30. Moore, W. M., et al., "An Introduction to Nondestructive Structural Evaluation of Pavements," TRB Circular 189, January 1978.

31. Nakamura, V. F., "Serviceability Ratings of Highway Pavements," M.S. thesis, Purdue University, June 1962.

32. Nie, N. H., et a1., "Statistical Package for the Social Sciences, Second Edition," McGraw-Hi11 Book Company, 1975.

33. Peterson, G., and Shepherd, L. W., "Deflection Analysis of Flexible Pavements," Utah State Highway Department, Final Report, January 1972.

34. Peterson, Gordon, "Predicting Performance of Pavements by Deflection Measurements," Utah DOT, final report, 1975.

35. Shelby, M. D., and Tutt, P. R., "Vehicle Speed and Placement Survey," HRB Bulletin 170, 1958.

36. Skok, E. L., and Kersten, M. S., "Surface Condition Rating System for Bituminous Pavements," NCHRP Research Results Digest No. 48, 1973.

37. Transportation Research Board, "Pavement Design and Management Systems," TRB Record 512, 1974.

38. Transportation Research Board, "Pavement Design, Performance, and Rehabilitation," Record 572, 1976.

39. Transportation Research Board, "Pavement Surface Properties and Vehicle Interaction," Record 584, 1976.

40. Transportation Research Board, "Status of Usage of Pavement Roughness Measuring Equipment," Results of Questionnaires by Committee A2B05 - Pavement Condition Evaluation, 1977.

41. U.S. Department of Transportation, "Highway Statistics Sumary to 1975, "U.S. Government Printing Office, Washington D.C.,

42. Vaswani, N. K., "Pavement Design and Performance Study, Phase B: Deflection Study, "Virginia Highway Research Council, Final Report VHRC 73-R52, May 1974.

43. Washington State Highway Commission, "Manual for Pavement Condition Rating Surveys," January 1977.

44. Yoder, E. J., and Milhous, R. T., "Comparison of Different Methods of Measuring Pavement Condition - Interim Report," NCHRP Report 7, 1964.

45. Yoder, E. J., and Witczak, M. W., "Principles of Pavement Design, 2nd Edition," John Wiley \& Sons, Inc., New York, 1975. 
APPENDICES 


\section{APPENDIX A}

Abstracts from the "Manual of Instructions for

Determing State Highway Needs," of the

Indiana State Highway Commission 
APPENDIX A

\section{GUIDELINE FOR DETERMINING STRUCTURAL CONDITION}

\section{General}

For evaluating the structural condition of any pavement subsection, it will be assumed that relative priorities can be assigned by a visual inspection of overall pavement performance. Structural condition will be coded after due consideration of the type and extent of pavement failure. Generally, such failure will be due to:

a) inadequacies in the composition and properties of the riding surface,

b) inadequate interrelation or action between the various elements of the entire pavement structure, and

c) inadequacies in the strength of material layers beneath the surface.

Failure may result due to any of the above or a combination of them. While it may be impossible to differentiate between these primary types of failure, all have one thing in common signs of surface distress. The condition will therefore be taken as indicative of the condition of the entire pavement structure on the assumption that failure of any portion of the structure is reflected by a corresponding surface distress.

The field observer will examine all evidence of existing and/or impending failure of the pavement structure. Elements to be considered included evidence of pumping, faulting, warping. map cracking, raveling, creeping, spalling, scaling, frost heave, failure of bituminous patching and resurfacing, chuck holes, washboarding, extruded joint filler, etc.

All visual signs of distress will be analyzed by the field observer and evaluated to determine the most compatible preventive maintenance required. The guidelines on the next page set forth deficiencies for both bituminous and portland cement concrete surface in terms of the extent of maintenance or construction requirements. The field observer will determine the maintenance requirement most closely approximating the observed condition and note the code number to be entered in accordance with Section 3 instructions.

The field observer is encouraged to consult with appropriate district personnel familiar with the maintenance problems associated with the highway sections being inventoried to aid in evaluating the structural condition. 


\title{
APPENDIX G CONTINUED
}

GUIDELINE FOR DETERININING STRUCTURAL CONDITION

\author{
OBSERVED CONDITION OF PAVEMENT SURFACE \\ BITUMINOUS SURFACES \\ P. C. CONCRETE SURFACES
}

\author{
MAINTENANCE \\ REQUIRED
}

CODE NO
No evidence of deformation or cracking. Smooth surface except for normal shrinkage cracking.
No evidence of displacement: no pumping. faulting, vertical alignment problems, etc. Slabs comparable to new in riding quality. May show map cracking on up to 5 per cent of surface area. Edges of cracks sharp. No evidence of spalling, scaling, of raveling of aggregates.
Very slight deformation and longitudinal cracking. Less than 10 per cent of surface area needs patchir:g.
No marked evidence of joint displacement and faultıng. Only slight vertical alignment protlems. Usual joint maintenance procedure adequate. Slight spalling at cracks. 0 to 10 per cent of area evidences map cracking. Very few major break-ups requiring patching.
None

Minor patching or

2 joint maintenance.
Very minor subgrade support problems, such as pumping, faulting, etc. Surface rough in some sections with few scattered chuck holes. Sorne aggregate raveled and exposed through surface scaling. About 10 to 25 per cent of arez shows map cracking.
Moderate Between 10 to 50 per cent of surface is in need of patching.

patching
Minor pumping, faulting and other displacement problems. Rough surface over most of section. Some raveled and exposed aggregate. 25 to 50 per cent of area shows map cracking.
Slight deformation and moderate cracking. About 50 per cent of surface in section is breaking uo in various stages.

Extensive

4 patching

Resurfacing 5

Considerable deformation and severe cracking with most of the surface showing evidence of break-up.
Minor subgrade support probiems such as pumping and faulting. Rough surface throughout section. Aggregate exposed and raveled out in some sections. 50.75 per cent of area shows map cracking.
Clear evidence of base and subyrade failure. Extremely distorted and broken surface.
Extremely poor riding quality. Evidence of this slab movement on passage of vehicles. Surface pitted and aggregate raveled out from scaled sections. 75 to 100 per cent shows map cracking.
Reconstruction 


\section{Guidelines for Determining Rideability}

37. RIDEABILITY: Field persorinel will observe the effect of physical features of the stibsection as they affect driving and riding comfort. Mark the approprate code as listed in the table below

\section{Existing Condition}

Comfortable at any reasonable operaung speed.

Rideability is adequate for traffic volume and type of service.

The quantities of excess crown, poor intersection contour, surface roughness or longitudinal un. eveness exist causing discomfort but not delay or hazards to traffic.

If the quantities considered above exist and there is delay or hazard to traffic.
Code

Excelient

Good

Fair

Poor

\section{Table Al: Instructions to Assign Sufficiency Ratings*}

STRUCTURAL ADEQUACY

Rated Element

RIDEABILITY
Convert the structural condition code (1tem 35) directly to a rating value as follows:

Maintenance Requirement
None
Minor patching or joint
maintenance
Moderate patching
Extensive patching
Resurfacing
Reconstruction

Judged As

None

Miror

Moderate

Extensive

Resurface

Reconst.
Rating 22 20 17 13

8

\section{Instruction}

Convert the rideability code (Item 37 ) direcily to the rating value as follows:
Rating

Judgod as

excellent

good

fair

poor 
APPENDIX B

Roadmeter Variability Study 
APPENDIX B

\section{Standard Conditions for Roadmeter Operation}

The following standard conditions are recommended to obtain a reliable estimate of pavement roughness in the state of Indiana using the roadmeter possessed by the Indiana State Highway Commission. These conditions are in addition to the roadmeter operating instructions given by the manufacturers and are based on the findings of the roadmeter variability study.

(1) Operating Speed. The roadmeter vehicle should be operated at a constant speed of $50 \mathrm{mph}$ while recording roughness measurements.

(2) Wind Velocity. The roadmeter calibration is valid only when the wind velocity is low, preferably less than $10 \mathrm{mph}$. If measurements are recorded at higher wind velocities, some adjustment may be necessary.

(3) Air Temperature. The roadmeter calibration is good for air temperatures from $15^{\circ} \mathrm{F}$ to $80^{\circ} \mathrm{F}$.

(4) Driving. Steady driving should be ensured during test.

(5) Loading. (i) the roadmeter vehicle should have no deadload except the roadmeter translator assembly case in the rear, the console assembly panel in the front and one spare tire.

(ii) During the test, only two persons should occupy

the front seat, one to drive the roadmeter and the other to operate the panel and record the measurements.

(6) Tire Pressure. A cold inflation pressure of 28 psi will be maintained in all 4 tires during test.

(7) Weather. Roughness measurements will be done only when the pavement surface is dry and clear of any ice, snow or water.

(8) Inside of roadmeter vehicle will be air conditioned and a normal temperature maintained during test.

(9) The roadmeter should be turned on and driven for several miles before its actual use on the test sections to allow all components to warm up. 
Table B1: Location Details of Test Sections

\begin{tabular}{|c|c|c|c|c|c|c|}
\hline $\begin{array}{l}\text { TEST } \\
\text { SECT NO }\end{array}$ & ROUTE & & COUNTY & $\begin{array}{l}\text { TYPE OF } \\
\text { PRUEMENT }\end{array}$ & PSR & LOCATION REFERENCE \\
\hline 1 & $I-65$ & NBL & TPCN & CRC & 4 & $\begin{array}{l}1.0 \text { FROM JCT I }-65 \mathrm{~N} / \mathrm{SR}-43 \\
\text {-AT CO. ROAD } 600 \mathrm{~N} \text { SIGN }\end{array}$ \\
\hline 2 & $I-65$ & NBL & TPCN & CRC & 4 & $\begin{array}{l}\text { 4.0 FROM JCT I-65 N/SR-43 } \\
\text {-AT MILE MARKET } 182\end{array}$ \\
\hline 3 & $I-65$ & NBL & WHIT & CRC & 3 & $\begin{array}{l}0.5 \text { FROM MILE MARKER } 188 \\
\text {-NEAR I-65 SIGN }\end{array}$ \\
\hline 4 & $I-65$ & NBL & WHIT & CRC & 4 & $\begin{array}{l}\text { 5.0 FROM JCT I-65 N/SR-18 } \\
\text {-AT231 TO WOLCOTT SIGN }\end{array}$ \\
\hline 5 & $I-65$ & NBL & WHIT & CRC & 4 & 0.9 FROM MILE MARKER 197 \\
\hline 6 & $I-65$ & NBL & JSPR & CRC & 5 & AT MILE MARKER 200 \\
\hline 7 & US-231 & NBL & JSPR & OUERLAY & 3 & 1.0 FROM JCT I-65 N/US-231 \\
\hline 8 & US-231 & NBL & JSPR & DUERLAY & 3 & $\begin{array}{l}\text { 4.0 FROM JCT I-65 N/US } 231 \\
\text {-AT US } 231-5 R \text { 16 SIGN }\end{array}$ \\
\hline 9 & US-231 & NBL & JSPR & DUERLAY & 2 & $\begin{array}{l}\text { 5.5 FROM JCT I-65 N/US-231 } \\
\text {-AT US-231 BRIDGE }\end{array}$ \\
\hline 10 & $S R-114$ & WBL & JSPR & FLEX & 3 & $\begin{array}{l}\text { 1.3 FROM JCT US-231/SR-114 } \\
\text {-AT SPEED LIMIT } 55 \text { SIGN }\end{array}$ \\
\hline 11 & SR-114 & WBL & JSPR & FLEX & 5 & 0.6 FROM JCT I-65,SR-114 \\
\hline 12 & $S R-55$ & SBL & NWTH & FLEX & 1 & 0.6 FROM JCT SR-55/SR-114 \\
\hline 13 & $S R-55$ & SBL & NWTN & FLEX & 1 & 4.5 FROM JCT SR-55/SR-114 \\
\hline 14 & $S R-55$ & SBL & NWTN & FLEX & 1 & 6.5 FROM JCT SR-55/SR-114 \\
\hline 15 & $S R-55$ & SBL & NWTN & FLEX & 1 & 8.9 FROM JCT SR-55/SR-114 \\
\hline 16 & $S R-55$ & SBL & NWTN & FLEX & 4 & $\begin{array}{l}0.3 \text { FROM JCT US-24/SR-55 } \\
\text {-AT SPEED LIMIT 55 SIGN }\end{array}$ \\
\hline 17 & $S R-55$ & SBL & BNTN & FLEX & 4 & $\begin{array}{l}\text { 3.9 FROM JCT US-24/SR-55 } \\
\text { AT SLIPPERY WHEN WET SIGN }\end{array}$ \\
\hline 18 & SR-55 & SBL & BNTN & FLEX & 4 & $\begin{array}{l}\text { 6.5 FROM JCT US-24/SR-55 } \\
\text {-AT SPEED LIMIT 55 SIGN }\end{array}$ \\
\hline 19 & US-52 & EBL & BNTN & DUERLAY & 3 & 0.3 FROM JCT US $-52 / S R-18$ \\
\hline 20 & US-52 & EBL & BNTN & $J R C$ & 2 & 2.8 FROM JCT US-52/SR-55 \\
\hline 21 & US -52 & EBL & BNTN & $J R C$ & 3 & 0.6 FROM JCT US-52/SR-352 \\
\hline 22 & US-52 & EBL & BNTN & OUERLAY & 2 & 2.3 FROM JCT US-52/SR-352 \\
\hline 23 & US-52 & EBL & BNTN & JRC & 3 & 5.4 FROM JCT US-52/SR-352 \\
\hline 24 & US-5e & $\mathrm{EBL}$ & TPCN & $J R C$ & 2 & 0.5 FROM TPCN CO. LINE \\
\hline 25 & US-52 & $E B L$ & TPCN & DUERLAY & 3 & $\begin{array}{l}\text { 4.0 FROM TPCN CO. LINE } \\
\text {-AT LAFAYETTE } 10 \text { SIGN }\end{array}$ \\
\hline
\end{tabular}


Table B2: Regression Coefficients for the Effect of Air Temperature

\begin{tabular}{|c|c|c|}
\hline PR GROUP & PR COMBINATION & $\begin{array}{l}\text { REGRESSION } \\
\text { CCEFFICIENTS }\end{array}$ \\
\hline 1 & $\begin{array}{l}\text { JRC } \\
\text { FLEXIBI_E-RUERAGE } \\
\text { OUERLAY - FUERAGE } \\
\text { OUERLAY - ROUGH }\end{array}$ & .0003395 \\
\hline 2 & $\begin{array}{ll}\text { JRE } & \text {-ROUGH } \\
\text { OUERLAY } & - \text { SHIOOTH }\end{array}$ & .0009722 \\
\hline 3 & FLEXIBLE-SMOOTH & .001736 \\
\hline 4 & $\begin{array}{ll}\text { CRC } & \text {-AUERAGE } \\
\text { FLEXIBLE-AUERAGE }\end{array}$ & .002608 \\
\hline 5 & -SMOOTH & .003101 \\
\hline
\end{tabular}


Table B3: Arrangement of Various Pavement TypeRoughness Groups into five Groups Having Equal Error of Roadmeter Measurements

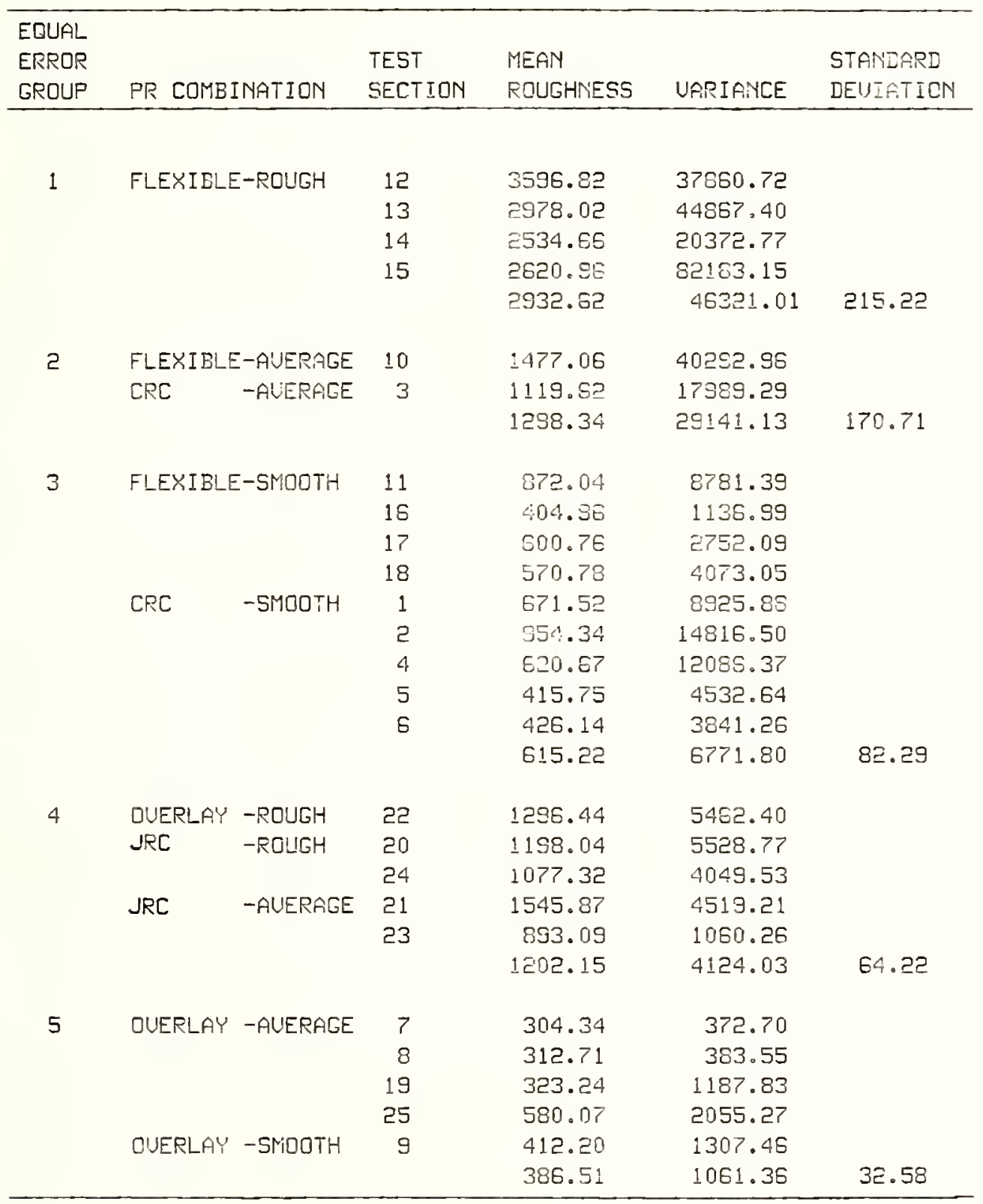


APPENDIX C

Selection of Test Sections 
APPENDIX C

Table C1: Loop No. 1, Location References of Test Sections

\begin{tabular}{|c|c|c|c|}
\hline $\begin{array}{l}\text { Test Section } \\
\text { No. }\end{array}$ & Route & County & Location Reference \\
\hline 1 & $\mathrm{I}-65 \mathrm{NBL}$ & TPCN & $\begin{array}{l}\text { 4.0 from Jct. }[-65 / S R-43 \\
\text { At Mile Marker } 182\end{array}$ \\
\hline 2 & I-65 NBL & WHIT & $\begin{array}{l}0.5 \text { from Mi le Marker } 188 \\
\text { At 'I-65' sign }\end{array}$ \\
\hline 3 & I-65 NBL & WHIT & $\begin{array}{l}0.9 \text { from Mile Marker } 197 \\
0.4 \text { from Co. Road } 1100 \mathrm{~W}\end{array}$ \\
\hline 4 & $\mathrm{I}-65 \mathrm{NBL}$ & JSPR & At Mile Marker 200 \\
\hline 5 & $S R-49 N B L$ & JSPR & 8.5 from Jct. SR-49/SR-14 \\
\hline 6 & SR-49 NBL & PRTR & 0.8 from Jct. SR-49/SR-8 \\
\hline 7 & $S R-49 N B L$ & PRTR & 5.5 from Jct. SR-49/SR-8 \\
\hline 8 & US-30 WBL & PRTR & $\begin{array}{l}1.0 \text { from Jct. US }-30 / S R-49 \\
\text { National Guard Armory sign }\end{array}$ \\
\hline 9 & $S R-2 W B L$ & PRTR & 1.5 from Jct. SR-2/US-30 \\
\hline 10 & $S R-2 W B L$ & PRTR & 3.7 from Jct. SR-2/US-30 \\
\hline 11 & $S R-2 W B L$ & PRTR & 10.0 from Jct. SR-2/US -30 \\
\hline 12 & $S R-10 W B L$ & JSPR & 8.0 from Jct. SR-2/US -231 \\
\hline 13 & SR-10 WBL & NWTN & 2.7 from Jct. SR-10/SR-55 \\
\hline 14 & US-41 SBL & NWTN & 0.9 from Jct. US $-41 /$ SR -10 \\
\hline 15 & $U S-41 S B L$ & NWTN & 3.5 from Jct. US- $41 /$ SR- 14 \\
\hline 16 & $U S-41 S B L$ & NWTN & 3.0 from Jct. US $-41 /$ SR -16 \\
\hline 17 & US-41 SBL & BNTN & 5.4 from Jct. US $-41 /$ US -24 \\
\hline 18 & US-41 SBL & BNTN & 0.3 from Jct. US $-41 /$ SR- 18 \\
\hline 19 & US-41 SBL & BNTN & 4.2 from Jct. US $-41 /$ SR- 18 \\
\hline 20 & SR-352 EBL & BNTN & 2.7 from Jct. US $-41 /$ SR -352 \\
\hline
\end{tabular}


Table C2: Loop No. 2, Location References of Test Sections

\begin{tabular}{|c|c|c|c|}
\hline $\begin{array}{l}\text { Test Section } \\
\text { No. }\end{array}$ & Route & County & Location Reference \\
\hline 1 & $\mathrm{SR}-25 \mathrm{NBL}$ & TPCN & $\begin{array}{l}4.3 \text { from Jct. } I-65 / S R-25 \\
1.1 \text { from Jct. SR-225/SR-25 }\end{array}$ \\
\hline 2 & $S R-218$ EBL & CARO & 1.2 from Jct. SR-75/SR-218 \\
\hline 3 & SR-29 NBL & CARO & 1.3 from Jct. SR-29/SR-218 \\
\hline 4 & SR-17 NBL & CASS & 5.0 from Logansport \\
\hline 5 & SR-16 EBL & CASS & 1.2 from Jct. SR-16/SR-17 \\
\hline 6 & $\mathrm{SR}-16 \mathrm{EBL}$ & CASS & 6.1 from Jct. SR-16/SR-25 \\
\hline 7 & US- $31 \quad N B L$ & MAMI & 5.8 from Jct. US- $31 /$ SR- 16 \\
\hline 8 & US-31 NBL & FLTN & 13.1 from Jct. US-31/SR-16 \\
\hline 9 & US-31 NBL & FLTN & 1.8 from Jct. US- $31 /$ SR- 14 \\
\hline 10 & US-31 NBL & FLTN & 3.8 from Jct. US $-31 / S R-14$ \\
\hline 11 & US-31 NBL & FLTN & 6.0 from Jct. US-31/SR-14 \\
\hline 12 & US- $31 \mathrm{NBL}$ & MARL & 1.3 from Jct. US-31/SR- 110 \\
\hline 13 & SR-10 WBL & MARL & 1.1 from Jct. US-31/SR-10 \\
\hline 14 & SR-10 WBL & MARL & 1.9 from Jct. SR-10/SR-17 S \\
\hline 15 & US-35 SBL & PULK & 2.3 from Jct. US-35/SR-10 \\
\hline 16 & SR-119 SBL & PULK & 1.7 from Jct. US-35/SR-119 \\
\hline 17 & $S R-39 S B L$ & WHIT & 4.9 from Jct. SR-39/SR-119 \\
\hline 18 & $S R-421 S B L$ & CARO & 5.0 from Jct. US $-421 /$ US -24 \\
\hline 19 & US-421 SBL & CARO & 8.5 from Jct. US-421/US-24 \\
\hline 20 & SR-18 WBL & WHIT & 3.4 from Jct. SR-18/US-421 \\
\hline
\end{tabular}


Table C3: Loop No. 3, Location References of Test Sections

Test Section

No.

1

2

3

4

5

6

7

8

9

10

11

12

13

14

15

16

17

18

19

20
Route

SR-25 SBL

$S R-25 S B L$

SR-25 SBL

SR-25 SBL

US-136 EBL

US-136 EBL

US-231 SBL

SR-236 EBL

SR-236 EBL

SR-75 SBL

SR-75 SBL

US-40 EBL

US-40 EBL

1-465 NBL

I-465 NBL

I-65 NBL

I -65 NBL

I -65 NBL

CLTN

I-65 NBL

TPCN

CLTN

HERK

HERK

HERK

HERK

HERK

MARN

MARN

HERK

TPCN
Location Reference

0.8 from Jct. SR-25/SR-43

4.5 from Jct. SR-25/SR-43

9.6 from Jct. SR-25/SR-43

10.9 from Jct. SR-25/SR-28W

1.6 from Jct. US-136/SR-25

6.0 from Jct. US $-136 /$ SR-25

1.0 from Jct. US-231/SR-234

2.0 from Jct. SR-236/US-231

9.8 from Jct. SR-236/US-231

4.5 from Jct. SR-75/SR-236

1.0 from Jct. SR-75/US- 36

4.3 from Jct. US $-40 /$ SR-75

12.5 from Jct. US-40/SR-75 At mailbox

1.7 from Exit $13 B$

0.6 from Mile Marker 127

At Mile Marker 18

3.5 from Jct. I-65/I-465 At Mile Marker 127

2.0 from Clinton Co. Line At Mile Marker 152

5.0 from $\mathrm{Clinton} \mathrm{Co}$. Line At Mile Marker 155

1.5 from Tippecanoe Co. Line At Mile Marker 162

12.5 from Tippecanoe Co. Line At Mile Marker 173 
Table C4: Loop No. 4, Location References of Test Sections

\begin{tabular}{clll}
\hline $\begin{array}{c}\text { Test Section } \\
\text { No. }\end{array}$ & Route & County & Location Reference \\
\hline 1 & SR-26 WBL & WARN & 0.4 from Warren Co. Line \\
2 & SR-26 WBL & WARN & 9.7 from Warren Co. Line \\
3 & US-41 SBL & WARN & 3.2 from Jct. US-41/SR-26 \\
4 & SR-63 SBL & WARN & 0.1 from Jct. US-41/SR-63 \\
5 & SR-63 SBL & WARN & 0.3 from Jct. SR-63/US-136 \\
6 & $1-74$ EBL & FNTN & At Mile Marker 10 \\
7 & $1-74$ EBL & MONT & At Mile Marker 27 \\
8 & SR-32 EBL & BOON & 0.8 from Jct. SR-32/SR-75 \\
9 & SR-32 EBL & BOON & 3.9 from Jct. SR-32/SR-75 \\
10 & US-52 WBL & BOON & 0.3 from Jct. US-52/I-65 \\
11 & US-52 WBL & BOON & 1.9 from Jct. US-52/SR-47 \\
12 & US-52 WBL & CLTN & 3.1 from Clinton Co. Line \\
13 & US-52 WBL & TPCN & 2.0 from Tippecanoe Co. Line \\
14 & US-52 WBL & TPCN & 1.7 from Jct. US-52/SR-28 \\
\hline
\end{tabular}


Table C5: Loop No. 5, Location References of Test Sections

\begin{tabular}{|c|c|c|c|}
\hline $\begin{array}{l}\text { Test Section } \\
\text { No. }\end{array}$ & Route & County & Location Reference \\
\hline 1 & $S R-43 N B L$ & TPCN & 1.6 from Jct. $\mathrm{I}-65 / \mathrm{SR}-43$ \\
\hline 2 & $S R-43 N B L$ & WHIT & 4.5 from Jct. SR-43/SR-18 \\
\hline 3 & $S R-43 N B L$ & WHIT & 7.5 from Jct. SR-43/SR-18 \\
\hline 4 & US-421 NBL & WHIT & $\begin{array}{l}1.0 \text { from Jct. US-24/US- } 421 \\
0.5 \text { from R.R. Crossing }\end{array}$ \\
\hline 5 & $S R-16$ EBL & WHIT & 1.3 from Jct. SR-16/US-421 \\
\hline 6 & $S R-39 N B L$ & WHIT & 1.4 from Jct. SR-39/SR-16 \\
\hline 7 & SR-39 NBL & PULK & 4.0 from Jct. SR-39/SR-14 \\
\hline 8 & $S R-39 N B L$ & STRK & 1.0 from Starke Co. Line \\
\hline 9 & SR-10 WBL & STRK & 1.5 from Jct. SR-39/SR-10 \\
\hline 10 & SR-10 WBL & STRK & 3.6 from Jct. SR-39/SR- 10 \\
\hline 11 & US-421 SBL & STRK & 0.2 from Jct. US- $421 / S R-10$ \\
\hline 12 & US -421 SBL & PULK & 0.6 from Jct. US-421/SR-14 \\
\hline 13 & SR-114 WBL & PULK & 1.7 from Jct. SR-114/US-421 \\
\hline 14 & SR-114 WBL & JSPR & 0.6 from Jct. I-65/SR- 114 \\
\hline 15 & $S R-55$ SBL & NWTN & 0.6 from Jct. SR-55/SR-114 \\
\hline 16 & $S R-55 S B L$ & NWTN & 4.5 from Jct. SR-55/SR-114 \\
\hline 17 & SR-55 SBL & NWTN & 6.5 from Jct. SR-55/SR-114 \\
\hline 18 & US-52 EBL. & BNTN & 0.3 from Jct. US $-52 / S R-18$ \\
\hline 19 & US-52 EBL & BNTN & 5.4 from Jct. US $-52 / S R-352$ \\
\hline 20 & US-52 EBL & TPCN & 0.5 from Tippecanoe Co. Line \\
\hline
\end{tabular}




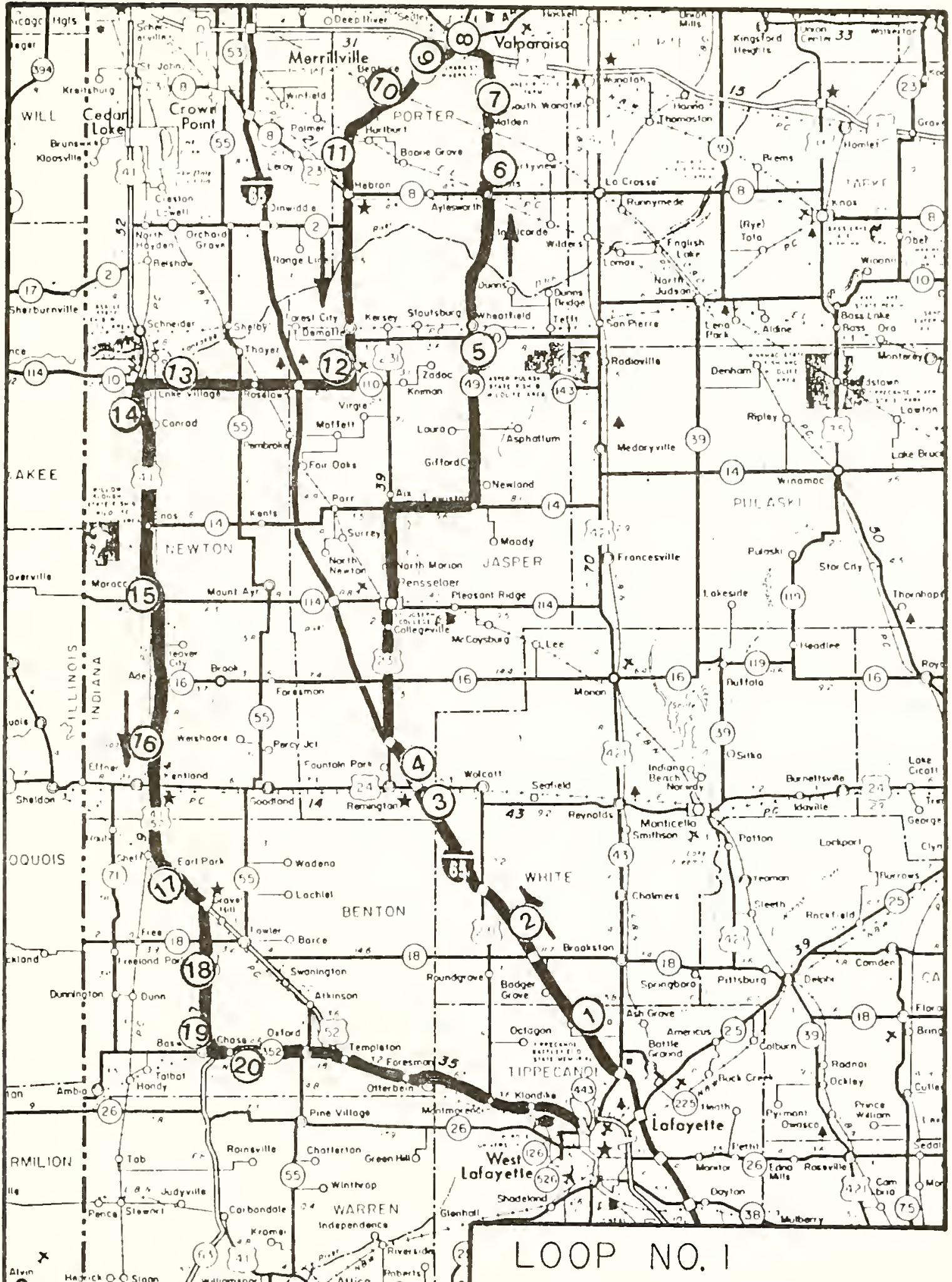

SCALE : $1^{\prime \prime}=10$ miles

No. of Test Sections $=20$ 




Figure C2: Map of Travel Loop No. 2 


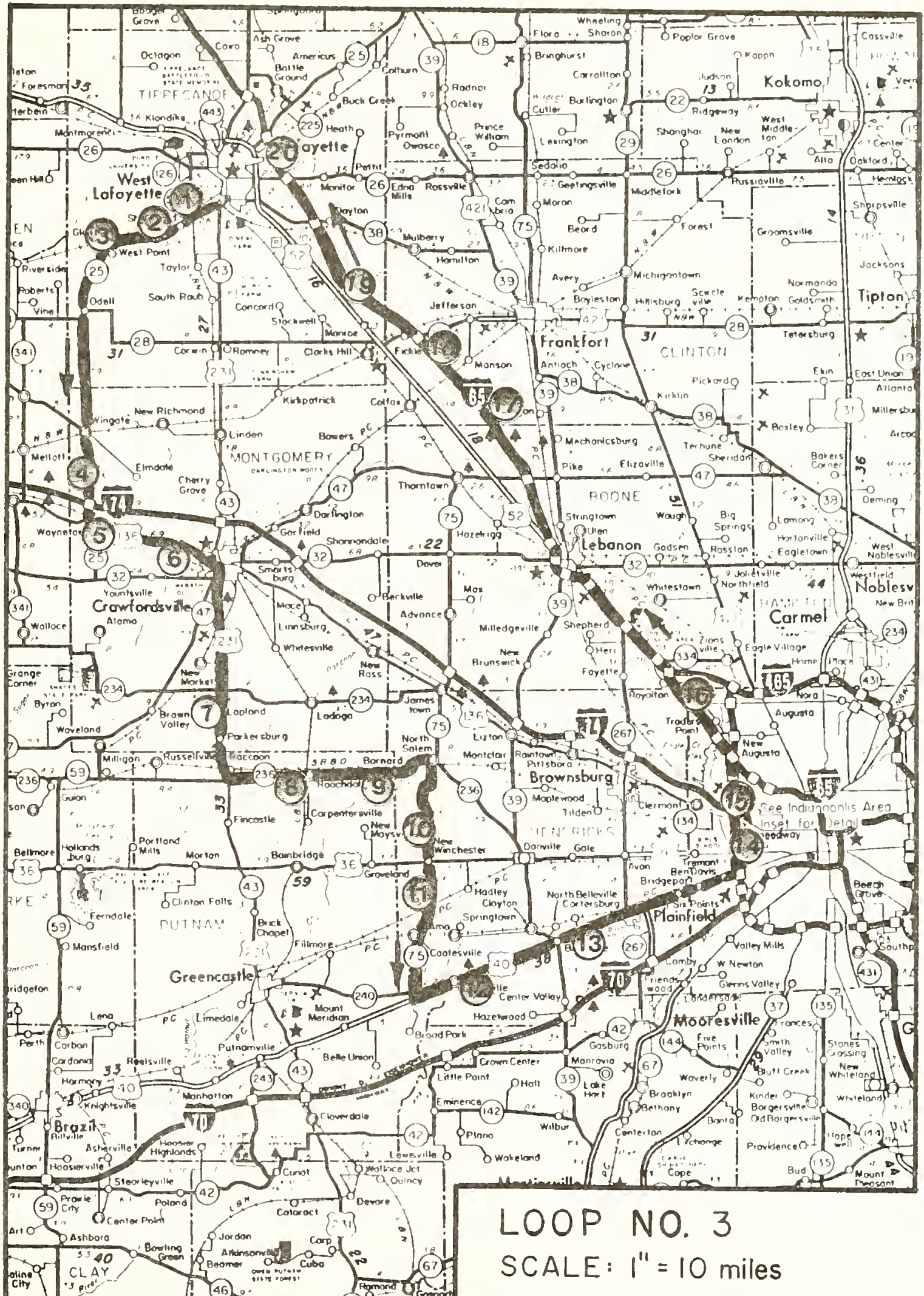

No. of Test Sections $=20$ 


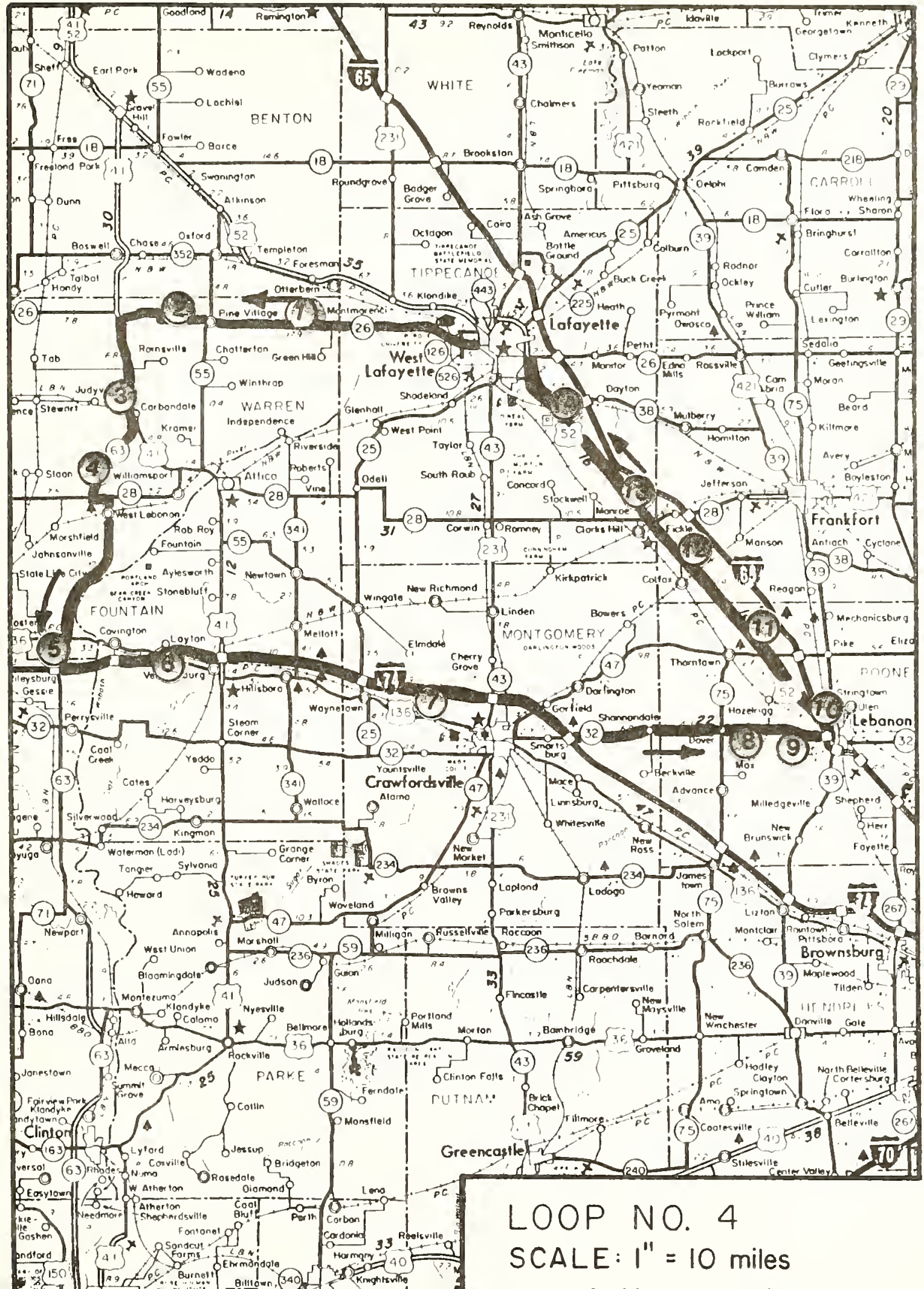

No. of Test Sections $=14$ 


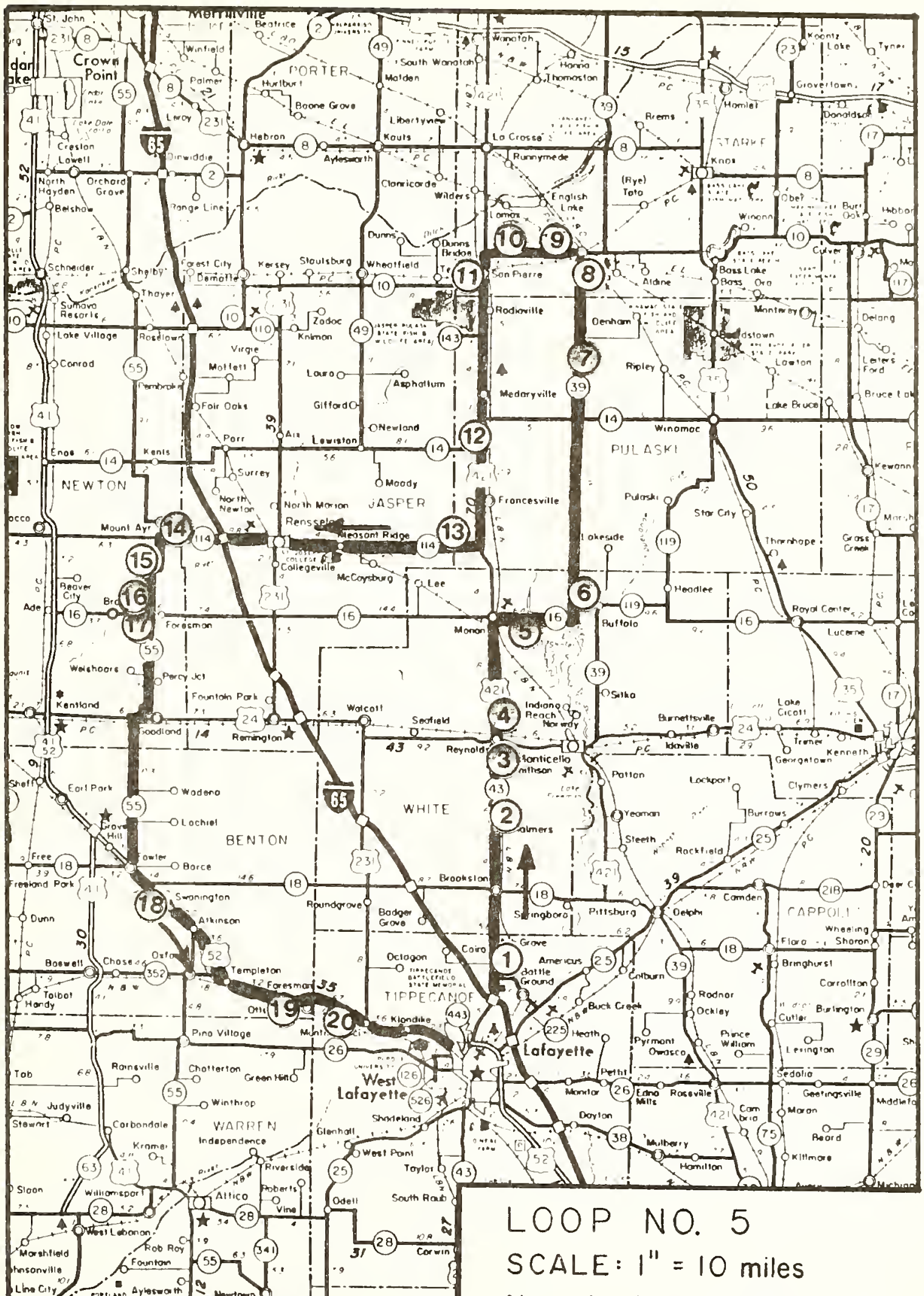

No. of Test Sections $=20$

Figure 5: Map of Travel Loop No. 5 
APPENDIX D

Pavement Serviceability Studies 
APPENDIX D

Table D1: Details of Raters

\begin{tabular}{|c|c|c|c|c|c|}
\hline $\begin{array}{c}\text { RATER } \\
\text { NO. }\end{array}$ & SEX & $\begin{array}{c}\text { AGE } \\
\text { (YRS) }\end{array}$ & OCCUPATION & $\frac{\text { TYPE OF }}{\text { SIZE }}$ & $\begin{array}{l}\text { CAR USED } \\
\text { AGE (YRS) }\end{array}$ \\
\hline 1 & MALE & 57 & LAB ASSISTANT & MEDIUM & 2 \\
\hline 2 & FEMALE & 26 & COMMUNITY PLANNER & SIMALL & 1 \\
\hline 3 & MALE & 54 & RESEARCH ENGINEER & BIG & 7 \\
\hline 4 & MALE & 55 & TRAFFIC TECHNICIAN & MEDIUM & 2 \\
\hline 5 & FEMALE & 30 & COMMUNITY PLANNER & MEDIUM & 2 \\
\hline 6 & MALE & 32 & ENGINEERING ASSISTANT & MEDIUM & 8 \\
\hline 7 & MALE & 25 & RESEARCH ENGINEER & NEDIUM & 3 \\
\hline 8 & MALE & 25 & MECHANIC & SMALL & 10 \\
\hline 9 & MALE & 54 & RESEARCH ENGINEER & SMALL & 6 \\
\hline 10 & MALE & 48 & ENG INEERING ASSISTANT & MEDIUM & 4 \\
\hline 11 & FEMALE & 32 & SECRETARY & MEDIUM & 6 \\
\hline 12 & FEMALE & 28 & SECRETARY & EIG & 5 \\
\hline 13 & MALE & 25 & LAB. TECHNICIAN & SMALL & 3 \\
\hline 14 & MALE & 37 & TRAINING OFFICER & SMALL & 1 \\
\hline 15 & MALE & 26 & ELECTRON TECHNICIAN & EIG & 5 \\
\hline 16 & MALE & 28 & ENGINEERING ASSISTANT & MEDIUM & 6 \\
\hline 17 & MALE & 55 & RESEARCH EIRECTOR & MEDIUM & 3 \\
\hline 18 & MALE & 26 & ENGINEERINIG ASSISTANT & MEDIUM & 15 \\
\hline 19 & MALE & 24 & PERMIT ENGINEER & MEDIUM & 2 \\
\hline 20 & MALE & 41 & ASST。 RESEARCH DIRECTOR & EIG & 6 \\
\hline
\end{tabular}


Table D2: Raters' Acceptability of Pavements

\begin{tabular}{|c|c|c|c|c|c|c|c|c|}
\hline TEST & TYPE & TYPE & MEAN & TOTAL & NUMBER OF RA & IERS. $\mathrm{B}$ & EMARKINE & PERCENT RATERS \\
\hline SECT & DF & & RATING & NO OF & ACCPT NOT & DOUBT & NO & ACCEPTING THE \\
\hline & ACILITY & PAUEMENI & (PSR) & RATERS & - ABLE ACPTBL & -FUL & DMMENTS & PAUEMENT \\
\hline
\end{tabular}

\begin{tabular}{|c|c|c|c|c|c|c|c|c|c|}
\hline $1 / 1$ & MULTILANE & CRC & 3.77 & 19 & 18 & 0 & 1 & 0 & 97.4 \\
\hline $1 / 2$ & MULTILANE & CRC & 3.79 & 19 & 19 & 0 & 0 & 0 & 100.0 \\
\hline $1 / 3$ & MULTILANE & CRC & 4.23 & 19 & 19 & 0 & 0 & 0 & 100.0 \\
\hline $1 / 4$ & MULTILANE & CRC & 4.23 & $18^{*}$ & 19 & 0 & 0 & 0 & 100.0 \\
\hline $1 / 5$ & TWO-LANE & FLEXIBLE & 2.28 & 19 & 13 & 4 & 2 & 0 & 73.7 \\
\hline $1 / 6$ & TWO-LANE & $J R C$ & 3.36 & 19 & 18 & 0 & 1 & 0 & 57.4 \\
\hline $1 / 7$ & TWO-LANE & $J R C$ & 3.68 & 19 & 18 & 1 & 0 & 0 & 94.7 \\
\hline $1 / 8$ & MULTILANE & OUERLAY & 2.96 & 19 & 16 & 2 & 1 & 0 & 86.8 \\
\hline $1 / 9$ & TWD-LANE & OUERLAY & 4.21 & 19 & 18 & 0 & 1 & 0 & 97.4 \\
\hline $1 / 10$ & TWO-LANE & DUERLAY & 4.32 & 19 & 19 & 0 & 0 & 0 & 100.0 \\
\hline $1 / 11$ & THO-LANE & OUERLAY & 2.72 & 19 & 16 & 2 & 1 & 0 & 86.8 \\
\hline $1 / 12$ & TWO-LANE & FLEXIBLE & 3.18 & 19 & 19 & 0 & 0 & 0 & 100.0 \\
\hline $1 / 13$ & TWD-LANE & FLEXIBLE & 1.87 & 19 & 10 & 8 & 1 & 0 & 55.3 \\
\hline $1 / 14$ & MULT ILANE & $J R C$ & 3.99 & 19 & 19 & 0 & 0 & 0 & 100.0 \\
\hline $1 / 15$ & MULTILANE & $J R C$ & 3.08 & 19 & 16 & 3 & 0 & 0 & 84.2 \\
\hline $1 / 16$ & NIULTILANE & $J R C$ & 3.30 & 19 & 19 & 0 & 0 & 0 & 100.0 \\
\hline $1 / 17$ & MULTILANE & JRC & 3.84 & 19 & 18 & 0 & 1 & 0 & 97.4 \\
\hline $1 / 18$ & MULT ILANE & $J R C$ & 4.14 & 19 & 19 & 0 & 0 & 0 & 100.0 \\
\hline $1 / 19$ & HULTILANE & JRC & 4.19 & 19 & 19 & 0 & 0 & 0 & 100.0 \\
\hline $1 / 20$ & TWO-LANE & FLEXIBLE & 3.31 & 19 & 17 & 0 & 1 & 1 & 97.2 \\
\hline $2 / 1$ & THDO-LANE & OUERLAY & 3.90 & 20 & 20 & 0 & 0 & 0 & 100.0 \\
\hline $2 / 2$ & TWD-LANE & FLEXIBLE & 2.85 & 20 & 19 & 0 & 1 & 0 & 97.5 \\
\hline $2 / 3$ & TWD-LAME & FLEXIBLE & 4.01 & 20 & 19 & 0 & 1 & 0 & 97.5 \\
\hline $2 / 4$ & TWO-LANE & OUERLAY & 1.93 & 20 & 10 & 9 & 1 & 0 & 52.5 \\
\hline $2 / 5$ & TWO-LANE & FLEXIBLE & 1.88 & 20 & 6 & 8 & 6 & 0 & 45.0 \\
\hline $2 / 6$ & TWO-LANE & FLEXIELE & 1.49 & 20 & 3 & 11 & 6 & 0 & 30.0 \\
\hline $5 / 7$ & MULTILANE & DUERLAY & 4.28 & $19^{\star}$ & 20 & 0 & 0 & 0 & 100.0 \\
\hline $2 / 8$ & MULT ILANE & CRC & 4.05 & 20 & 20 & 0 & 0 & 0 & 100.0 \\
\hline $2 / 9$ & MULTILANE & CRC & 4.06 & 20 & 20 & 0 & 0 & 0 & 100.0 \\
\hline $2 / 10$ & MULTILANE & CRC & 4.02 & 20 & 19 & 0 & 1 & 0 & 97.5 \\
\hline $2 / 11$ & MULTILANE & CRC & 3.98 & 20 & 20 & 0 & 0 & 0 & 100.0 \\
\hline $2 / 12$ & MULTILANE & $J R C$ & 4.02 & 20 & 19 & 1 & 0 & 0 & 95.0 \\
\hline $2 / 13$ & THO-LANE & FLEXIBLE & 1.77 & 20 & 6 & 11 & 3 & 0 & 37.5 \\
\hline $2 / 14$ & TWO-LANE & FLEXIBLE & 2.29 & $19^{\star}$ & 13 & 2 & 5 & 0 & 81.6 \\
\hline $2 / 15$ & TWO-LANE & FLEXIBLE & 3.62 & 20 & 20 & 0 & 0 & 0 & 100.0 \\
\hline $2 / 16$ & TWO-LANE & FLEXIBLE & 2.72 & $19^{\star}$ & 16 & 2 & 1 & 1 & 91.7 \\
\hline $2 / 17$ & THO-LANE & FLEXIELE & 3.60 & 20 & 19 & 1 & 0 & 0 & 95.0 \\
\hline $2 / 18$ & TWO-LANE & FLEXIBLE & 3.40 & 20 & 19 & 0 & 1 & 0 & 97.5 \\
\hline $2 / 19$ & TWO-LANE & FLEXIBLE & 3.57 & 20 & 19 & 0 & 1 & 0 & 97.5 \\
\hline $5 / 20$ & TWO-LANE & DUERLAY & 3.42 & 20 & 18 & 1 & 1 & 0 & 92.5 \\
\hline $3 / 1$ & TWO-LANE & DUERLAY & 4.13 & 20 & 20 & 0 & 0 & 0 & 100.0 \\
\hline $3 / 2$ & TWO-LANE & DUERLAY & 4.14 & 20 & 20 & 0 & 0 & 0 & 100.0 \\
\hline $3 / 3$ & TWO-LANE & OUERLAY & 3.00 & 20 & 17 & 2 & 1 & 0 & 87.5 \\
\hline $3 / 4$ & TWD-LANE & FIEXIBLE & 3.23 & 20 & 19 & 0 & 1 & 0 & 97.5 \\
\hline $3 / 5$ & TWO-LANE & DUERLAY & 2.49 & 20 & 15 & 1 & 4 & 0 & 85.0 \\
\hline $3 / 6$ & THO-LANE & OUERLAY & 2.48 & 20 & 15 & 2 & 3 & 0 & 82.5 \\
\hline $3 / 7$ & TWD-LANE & OUERLAY & 3.86 & 20 & 19 & 0 & 1 & 0 & 97.5 \\
\hline
\end{tabular}


Table D2: Continued

\begin{tabular}{cccccccc}
\hline TEST & TYPE & TYPE & MEAN TOTAL NUMBER OF RATERS REMARKING & PERCENT RATERS \\
SECT & OF & OF & RATING ND OF ACCPT NOT DOUBT NO N N ACCEPTING THE \\
NO FACILITY & PAUEMENT & (PSR) & RATERS & -ABLE ACPTBL & -FUL COMMENTS & PAUEMENT \\
\hline
\end{tabular}

\begin{tabular}{|c|c|c|c|c|c|c|c|c|c|}
\hline $3 / 8$ & TWO-LANE. & FLEXIBLE & 3.57 & 20 & 19 & 0 & 1 & 0 & 97.5 \\
\hline $3 / 9$ & TWO-LANE & FLEXIBLE & 3.91 & 20 & 19 & 1 & 0 & 0 & 95.0 \\
\hline $3 / 10$ & TWO-LANE & FLEXIBLE & 2.81 & 20 & 14 & 2 & 2 & 2 & 83.3 \\
\hline $3 / 11$ & TWO-LANE & FLEXIBLE & 3.37 & 20 & 19 & 1 & 0 & 0 & 95.0 \\
\hline $3 / 12$ & MULTILANE & OUERLAY & 4.12 & 20 & 20 & 0 & 0 & 0 & 100.0 \\
\hline $3 / 13$ & MULTILANE & OUERLAY & 3.44 & 20 & 20 & 0 & 0 & 0 & 100.0 \\
\hline $3 / 14$ & MULTILANE & JRC & 3.65 & 20 & 18 & 1 & 1 & 0 & 92.5 \\
\hline $3 / 15$ & MULT ILANE & JRC & 3.89 & 20 & 20 & 0 & 0 & 0 & 100.0 \\
\hline $3 / 16$ & MULTILANE & OUERLAY & 4.38 & 20 & 20 & 0 & 0 & 0 & 100.0 \\
\hline $3 / 17$ & MULTILANE & CRC & 3.60 & 20 & 19 & 0 & 1 & 0 & 97.5 \\
\hline $3 / 18$ & MULTILANE & CRC & 3.75 & 20 & 20 & 0 & 0 & 0 & 100.0 \\
\hline $3 / 19$ & IUULTILANE & CRC & 4.11 & 20 & 18 & 0 & 1 & 1 & 97.4 \\
\hline $3 / 20$ & MULTILANE & CRC & 4.14 & 20 & 19 & 0 & 1 & 0 & 97.5 \\
\hline $4 / 1$ & TWO-LANE & FLEXIBLE & 2.93 & 20 & 19 & 0 & 1 & 0 & 97.5 \\
\hline $4 / 2$ & THD-LANE & FLEXIELE & 2.73 & 20 & 18 & 0 & 2 & 0 & 95.0 \\
\hline 4,3 & MULTILGNE & $J R C$ & 4.07 & 20 & 18 & 0 & 1 & 1 & 97.4 \\
\hline $4 / 4$ & MULTILANE & $\mathrm{JRC}$ & 3.88 & 20 & 19 & 0 & 1 & 0 & 97.5 \\
\hline $4 / 5$ & TWO-LANE & JRC & 2.99 & 20 & 18 & 1 & 1 & 0 & 92.5 \\
\hline $4 / 6$ & MULT ILANEE & $J R C$ & 3.03 & 20 & 18 & 2 & 0 & 0 & 90.0 \\
\hline $4 / 7$ & MULT ILAME & $J R C$ & 3.75 & 20 & 20 & 0 & 0 & 0 & 100.0 \\
\hline $4 / 8$ & TWO-LANE & FLEXIBLE & 3.50 & 20 & 20 & 0 & 0 & 0 & 100.0 \\
\hline $4 / 9$ & TWO-LANE & FLEXIBLE & 3.11 & 20 & 17 & 1 & 0 & 2 & 94.4 \\
\hline $4 / 10$ & MULTILANE & OUERLAY & 3.03 & 20 & 18 & 0 & 2 & 0 & 95.0 \\
\hline $4 / 11$ & MULTILANE & JRC & 3.52 & 20 & 20 & 0 & 0 & 0 & 100.0 \\
\hline $4 / 12$ & MULT ILANE & OUERLAY & 3.20 & 20 & 19 & 0 & 0 & 1 & 100.0 \\
\hline $4 / 13$ & MULT ILANE & DUERLAY & 3.29 & 20 & 20 & 0 & 0 & 0 & 100.0 \\
\hline $4 / 14$ & MULTILANE & OUERLAY & 3.05 & 20 & 19 & 0 & 0 & 1 & 100.0 \\
\hline $5 / 1$ & TWO-LANE & QUERLAY & 4.00 & 20 & 20 & 0 & 0 & 0 & 100.0 \\
\hline $5 / 2$ & TWO-LANE & OUERLAY & 3.29 & 20 & 18 & 0 & 1 & 1 & 97.4 \\
\hline $5 / 3$ & THC-LAIVE & OUERLAY & 3.10 & 20 & 18 & 1 & 0 & 1 & 94.7 \\
\hline $5 / 4$ & TWO-LANE & OVERLAY & 3.54 & 20 & 20 & 0 & 0 & 0 & 100.0 \\
\hline $5 / 5$ & TWO-LANE & FLEXIBLE & 2.05 & 20 & 10 & 7 & 3 & 0 & 57.5 \\
\hline $5 / 6$ & TWO-LANE & FLEXIBLE & 2.39 & 20 & 14 & 4 & 2 & 0 & 75.0 \\
\hline $5 / 7$ & TWO-LANE & FLEXIBLE & 1.96 & 20 & 9 & 9 & 2 & 0 & 50.0 \\
\hline $5 / 8$ & TWO-LANE & FLEXIBLE & 3.62 & 20 & 18 & 0 & 1 & 1 & 97.4 \\
\hline $5 / 9$ & TWO-LANE & FLEXIELE & 3.30 & 20 & 17 & 0 & 1 & 2 & 97.2 \\
\hline $5 / 10$ & TWO-LANE & FLEXIBLE & 2.97 & 20 & 17 & 1 & 2 & 0 & 90.0 \\
\hline $5 / 11$ & TWO-LANE & FLEXIELE & 3.72 & 20 & 19 & 0 & 0 & 1 & 100.0 \\
\hline $5 / 12$ & TWO-LANE & FLEXIBLE & 3.55 & 20 & 17 & 0 & 2 & 1 & 94.7 \\
\hline $5 / 13$ & THO-LANE & FLEXIBLE & 2.89 & 20 & 17 & 2 & 1 & 0 & 87.5 \\
\hline $5 / 14$ & TWO-LANE & FLEXIBLE & 3.67 & 20 & 19 & 0 & 1 & 0 & 97.5 \\
\hline $5 / 15$ & TWO-LANE & FLEXIBLE & 1.51 & 20 & 4 & 14 & 2 & 0 & 25.0 \\
\hline $5 / 16$ & THO-LANE & FLEXIBLE & 1.43 & $19^{\star}$ & 1 & 17 & 2 & 0 & 10.5 \\
\hline $5 / 17$ & TWO-LANE & FLEXIBLE & 1.43 & 20 & 5 & 14 & 1 & 0 & 27.5 \\
\hline $5 / 18$ & MULTILANE & OUERLAY & 3.50 & 20 & 19 & 0 & 0 & 1 & 100.0 \\
\hline $5 / 19$ & MULTI LANE & $J R C$ & 3.55 & 20 & 19 & 0 & 1 & 0 & 97.5 \\
\hline $5 / 20$ & MULTILANE & $J R C$ & 3.33 & 20 & 19 & 0 & 1 & 0 & 97.5 \\
\hline
\end{tabular}

*In these test sections, the raters did not mark the rating scale but commented on the acceptability of pavements. 


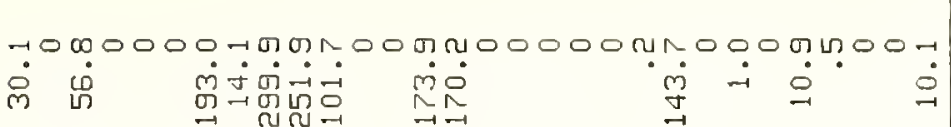

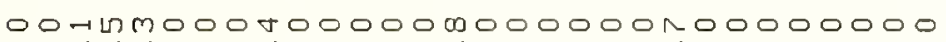
लึखญ ณี

in $\dot{\infty}$

R! ஸ்

$0-10000000000000000000000000000$ in

m กำด

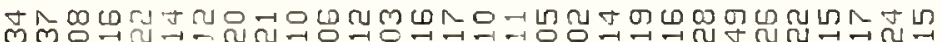
mलо.

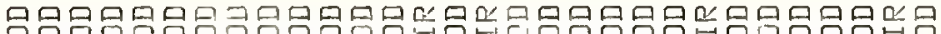

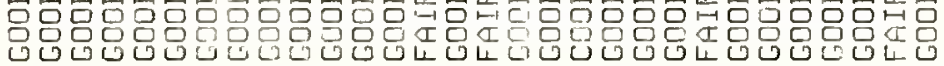

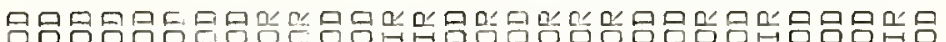

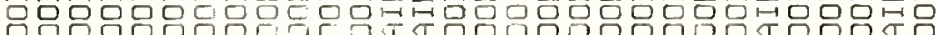

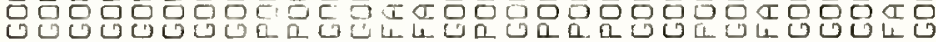

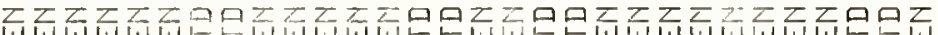

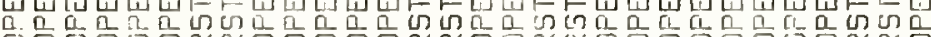

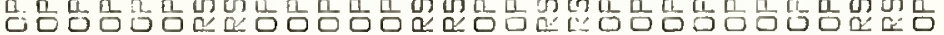

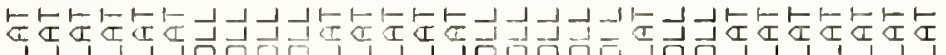

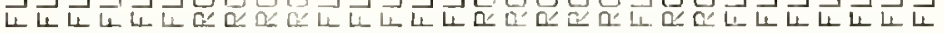

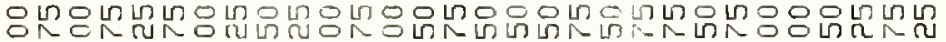

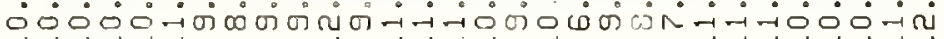

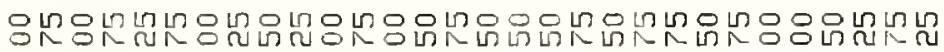

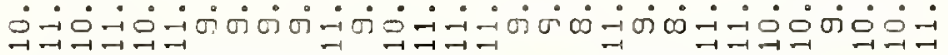

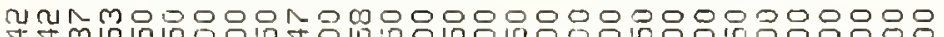

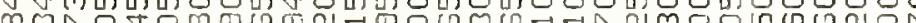
ญ

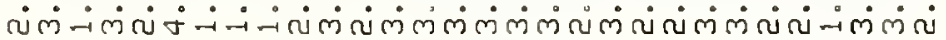

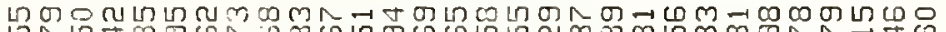

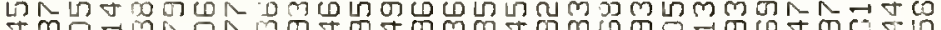

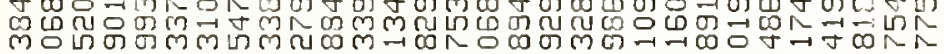

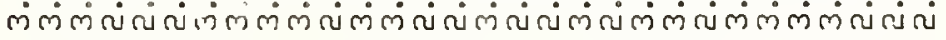

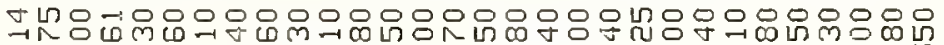

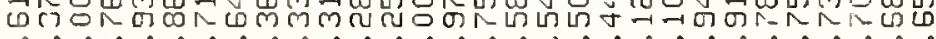
-

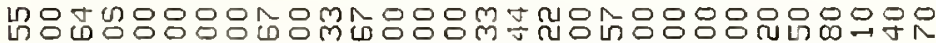
نñ

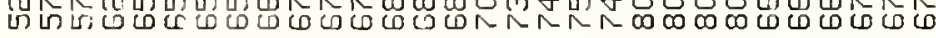

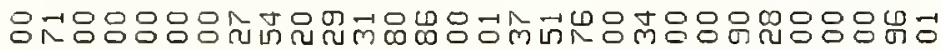

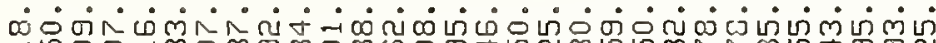
m-

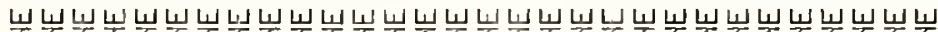

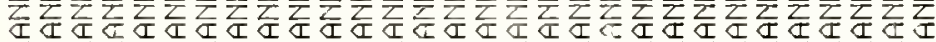

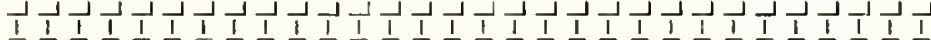

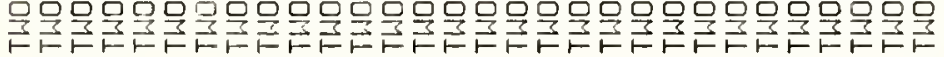
ம

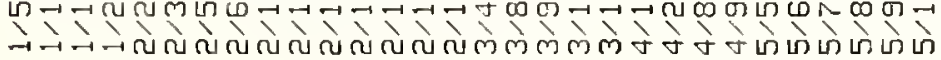




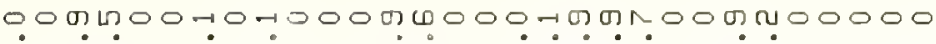

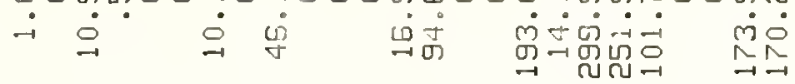

$00000000000000 m 000400000000000$

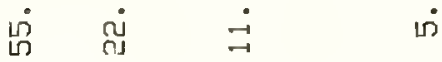

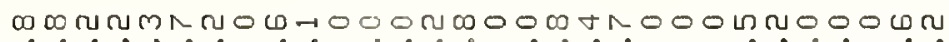

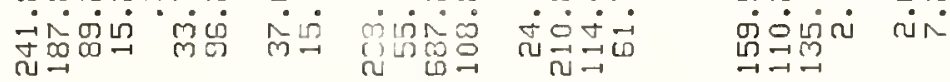
000000000000000000000000000000

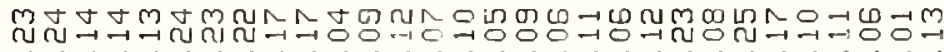

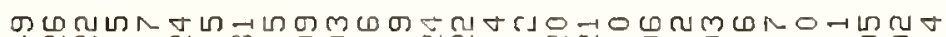

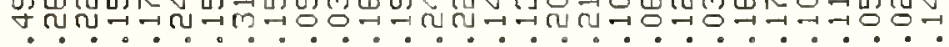

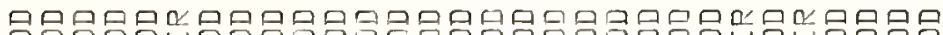

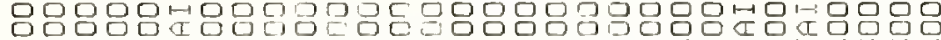

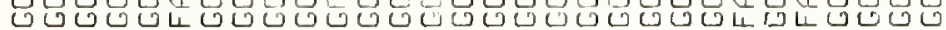

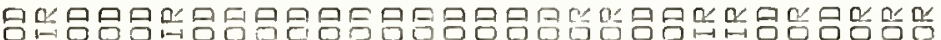

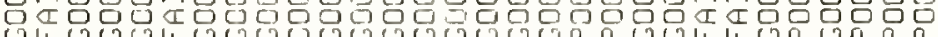

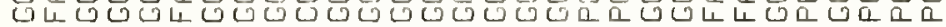

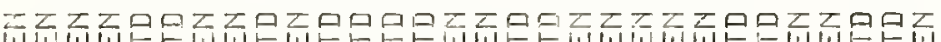

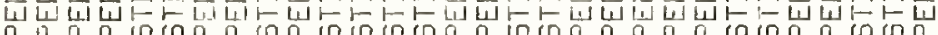

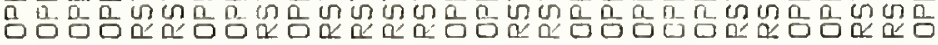

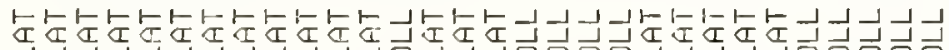

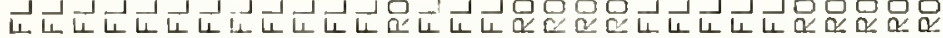

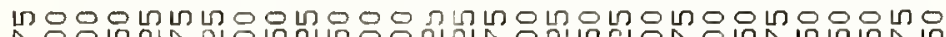

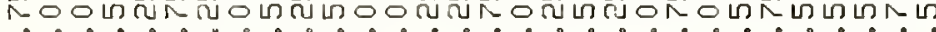

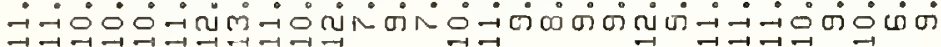

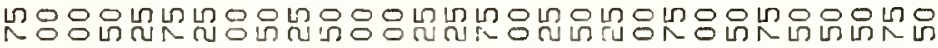

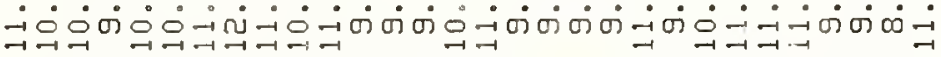

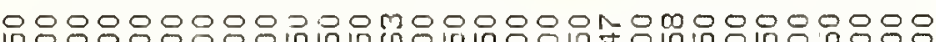

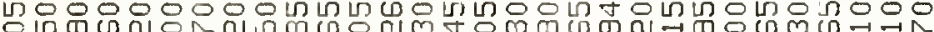

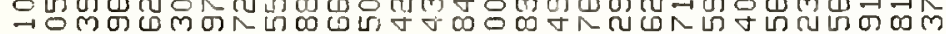

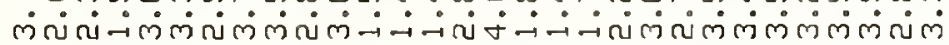
ญ

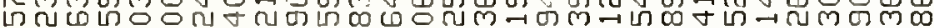

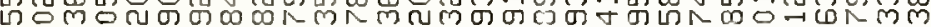

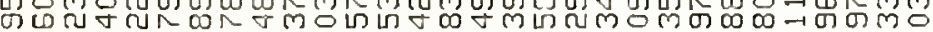

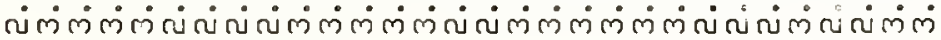

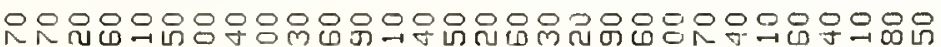

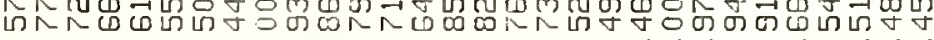

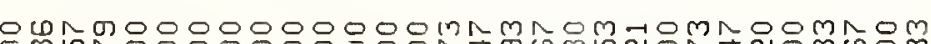

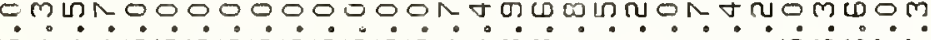

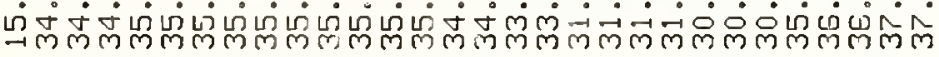

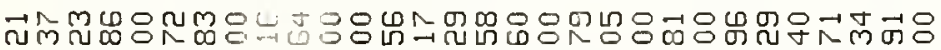

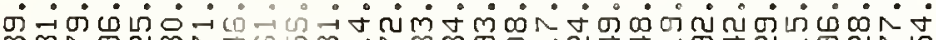

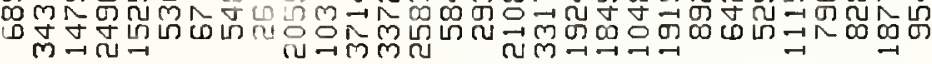

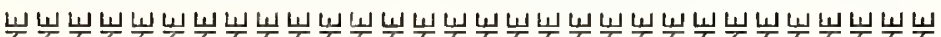

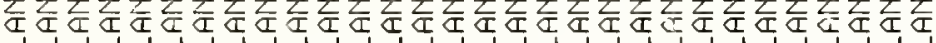

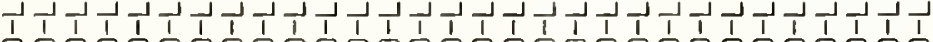

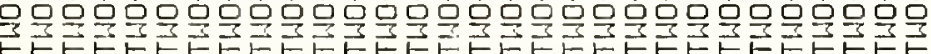
бщம

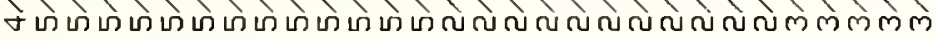


он,

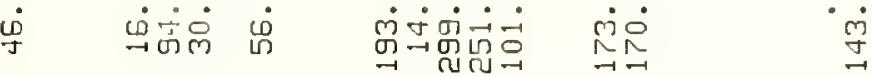
$0000000007 \ln 0007000000000000 \mathrm{~N}$ ம்

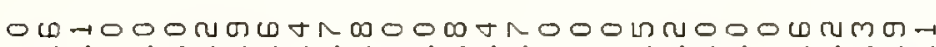

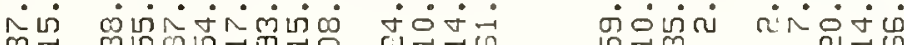

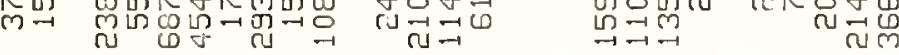
$00000000-1000000000000000000000$ in

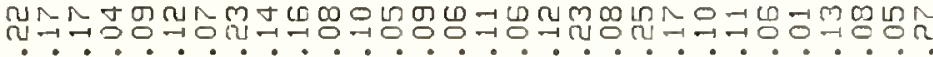

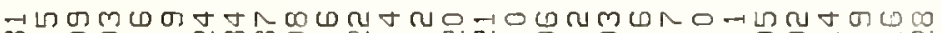

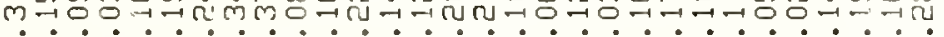

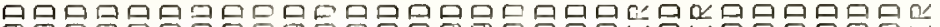

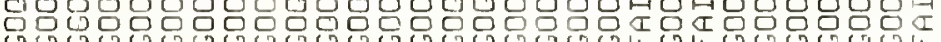
他

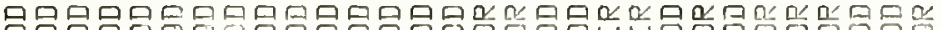

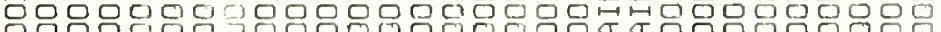

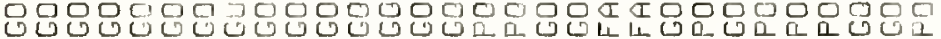

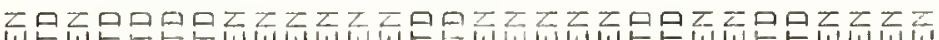

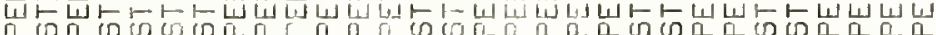

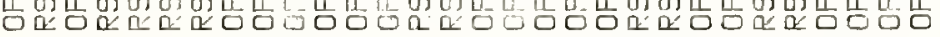

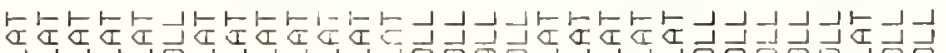

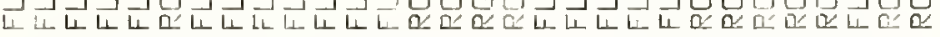

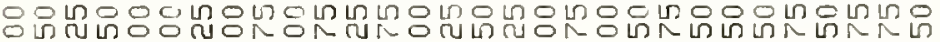

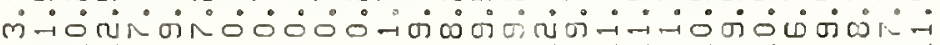

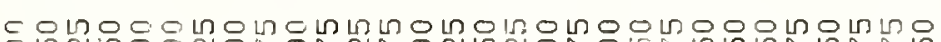

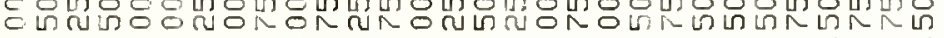

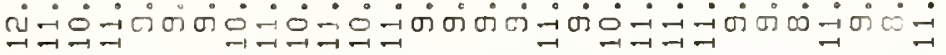

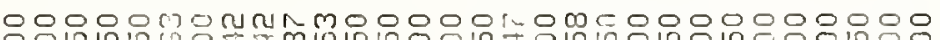

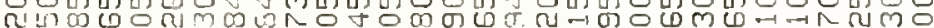

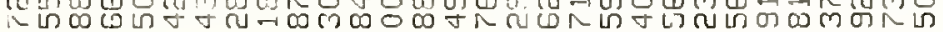

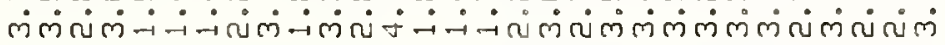

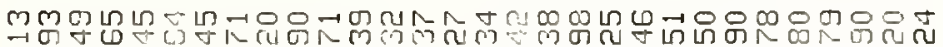

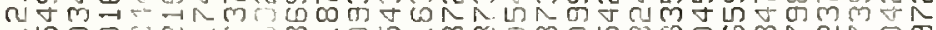

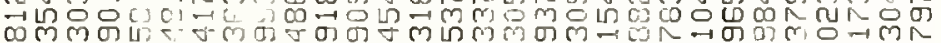

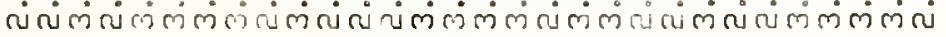

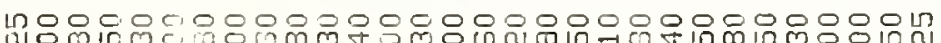
ขอำ -

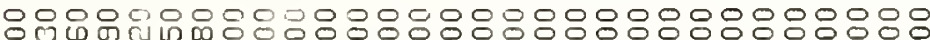

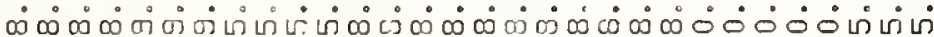

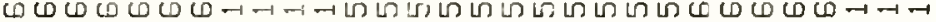

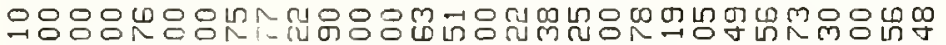

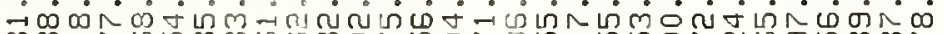
D m $N$ W

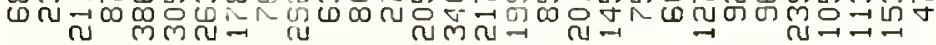

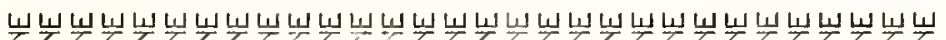

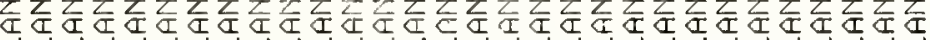
1 $11+1$

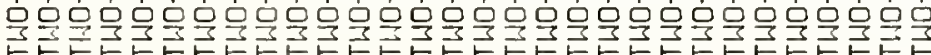

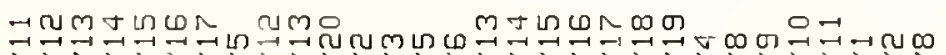

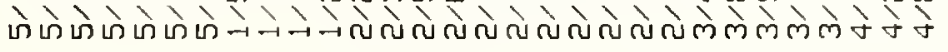




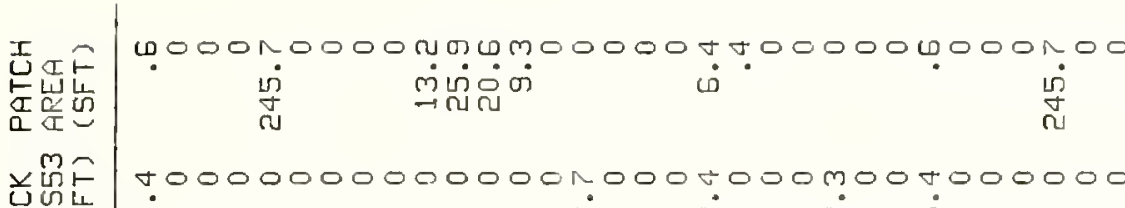

组

方蛇

沱

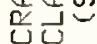

का वान00000

ำ

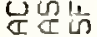

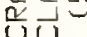

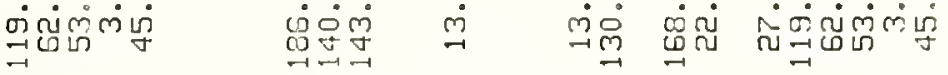

능롱

00000000000000000000000000000000

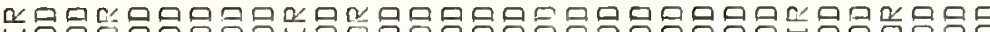

I我

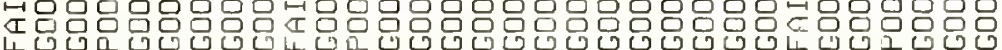

吉的

in

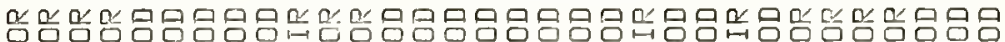

$\rightarrow$ 단

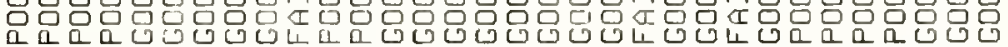

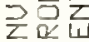

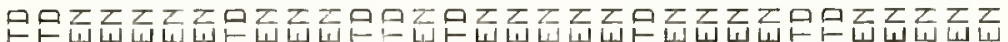

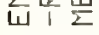

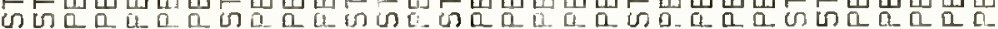

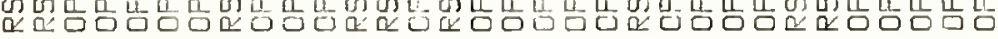

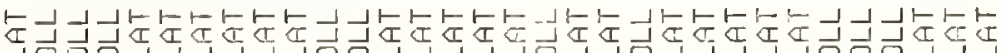

U山I

山己

究白

岀个是

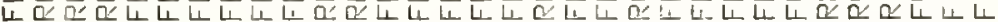

至次

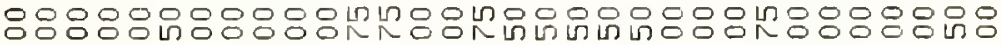

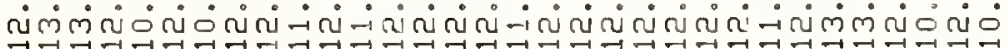

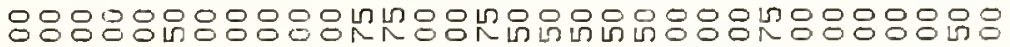

突沓怘

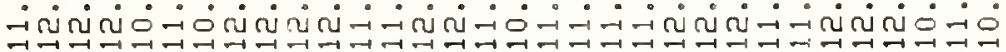

눙

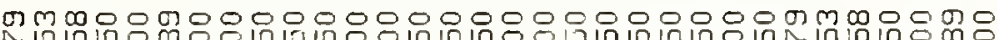
然 ตূल

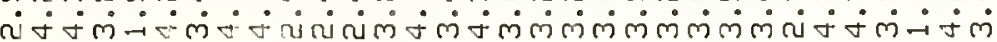

吕立命

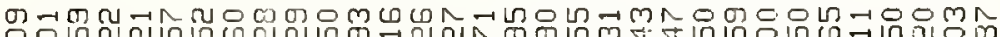

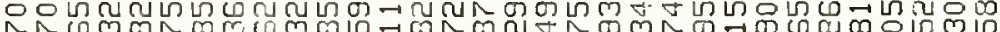

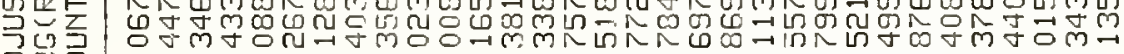
๔.

西 元

兴空金

㟧乞

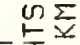

$\sum_{x} \zeta_{\alpha}$

문

点

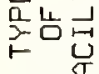

눈

$\vdash \vdash$

넌운

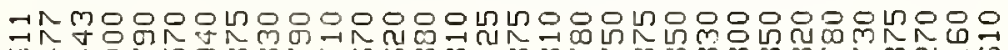
U.

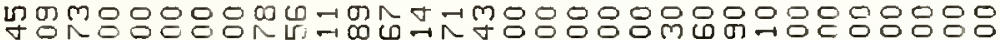

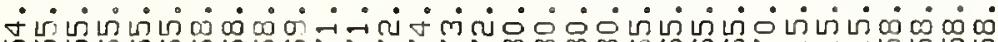

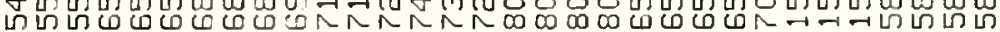

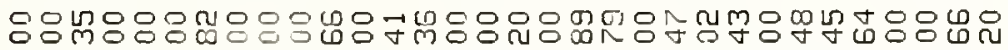

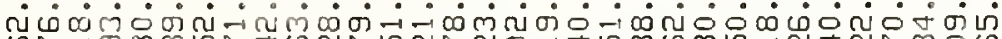

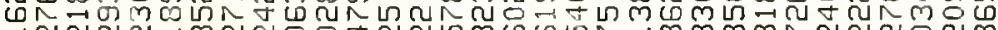
ન

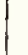

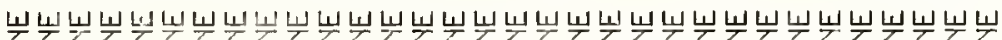

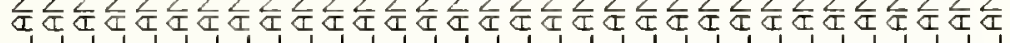

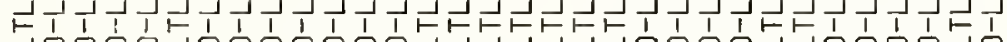

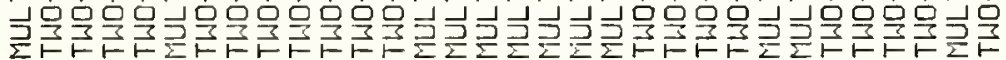

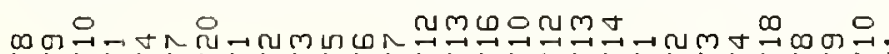
ने ने ते ते ते ले ले ले ले ले ले ले ले ने ने ने डे डो 


\begin{tabular}{|c|c|}
\hline tu & 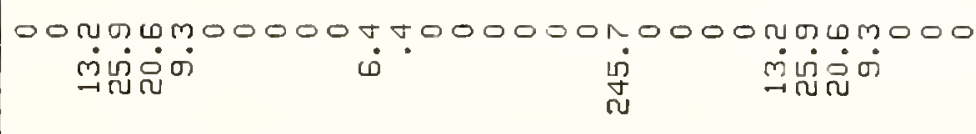 \\
\hline & $\begin{array}{c}00000000007000 m 0000000000000 \Omega \\
\dot{m} \text { i }\end{array}$ \\
\hline & 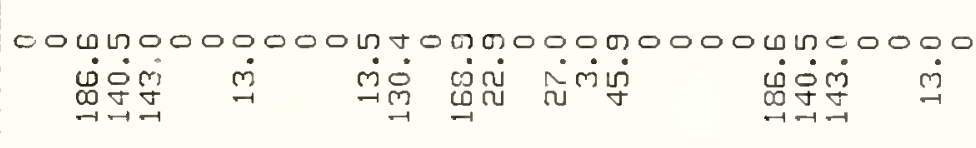 \\
\hline & 00 \\
\hline & 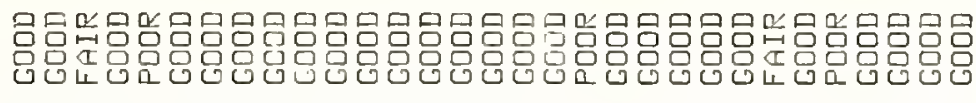 \\
\hline & 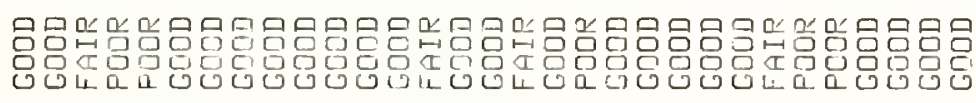 \\
\hline & 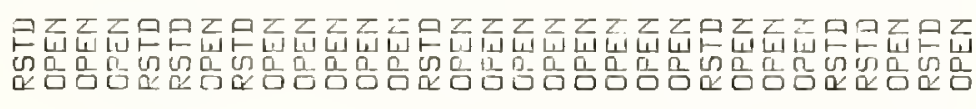 \\
\hline & $\vdash$ \\
\hline & $\stackrel{8}{\mathbb{C}_{-1}}$ \\
\hline & 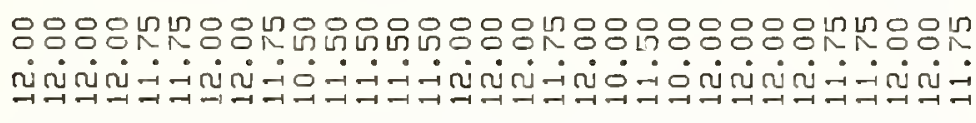 \\
\hline & 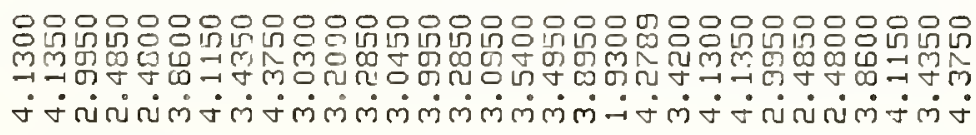 \\
\hline 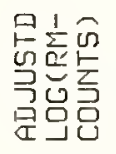 & 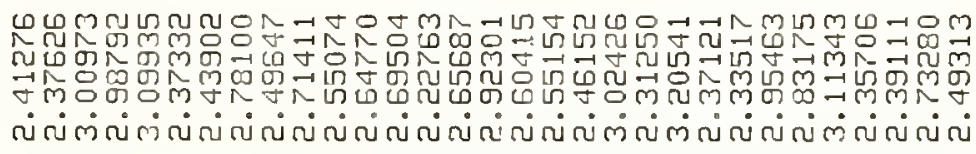 \\
\hline & 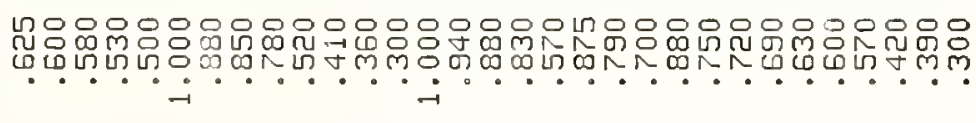 \\
\hline & 00000 \\
\hline & 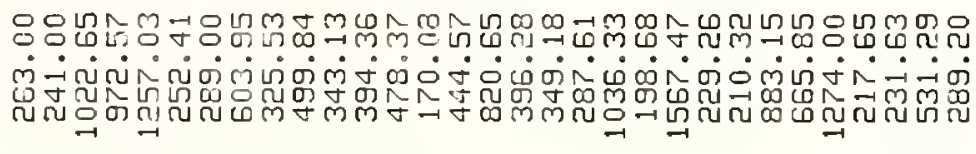 \\
\hline & 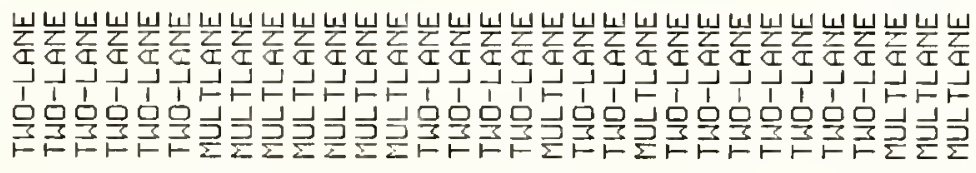 \\
\hline 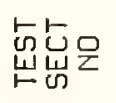 & . \\
\hline
\end{tabular}




\begin{tabular}{|c|c|}
\hline : & 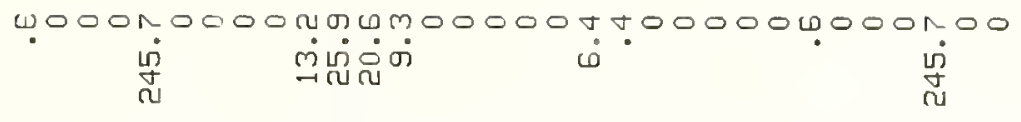 \\
\hline & 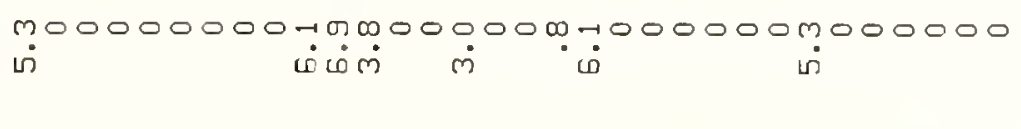 \\
\hline[ & 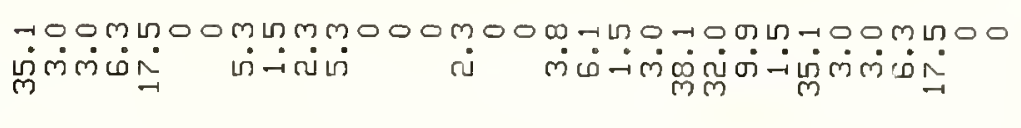 \\
\hline & 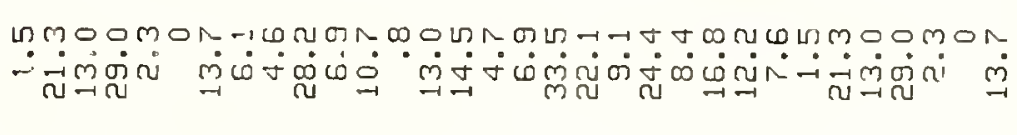 \\
\hline & 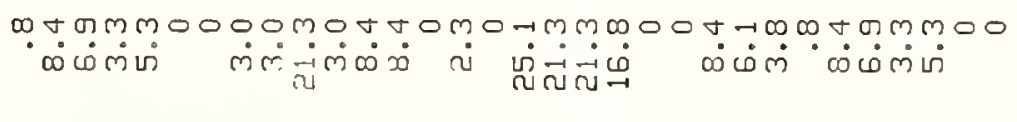 \\
\hline & 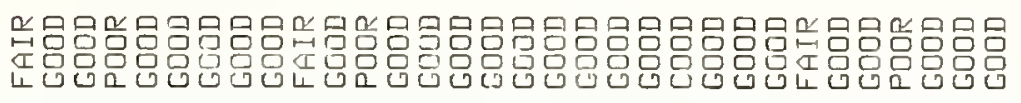 \\
\hline & 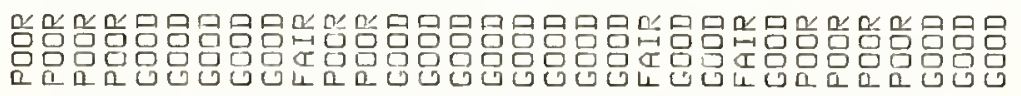 \\
\hline & 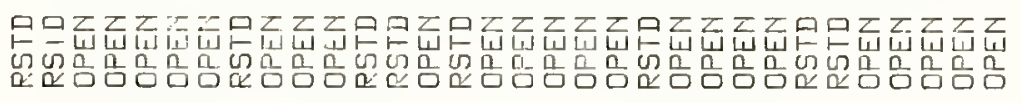 \\
\hline & 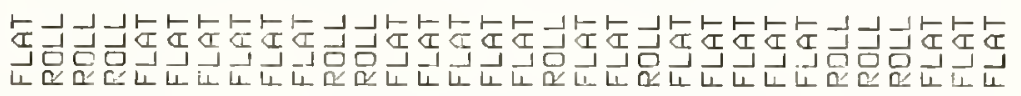 \\
\hline & 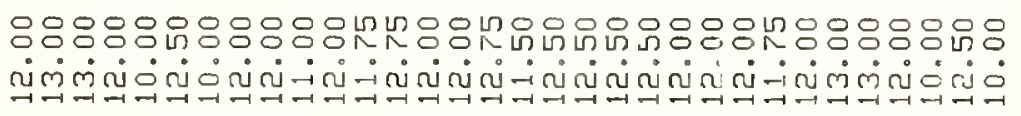 \\
\hline & 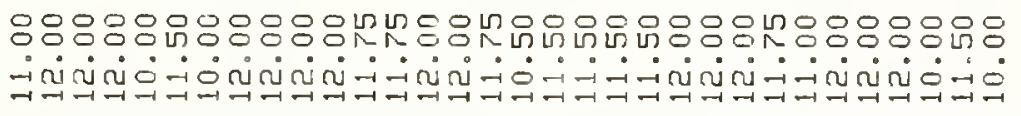 \\
\hline & 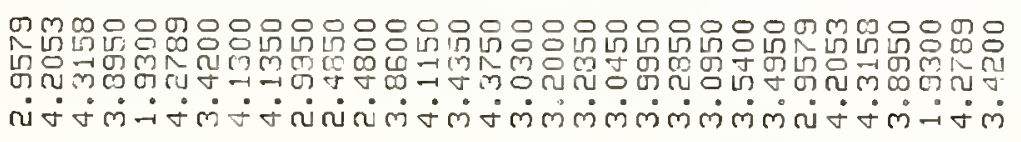 \\
\hline & 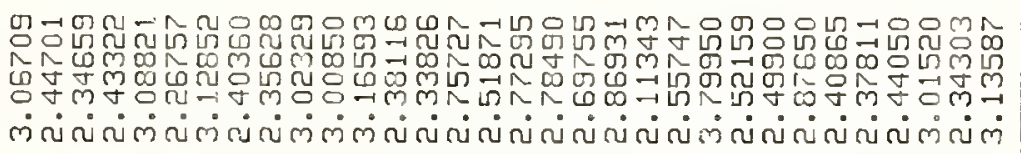 \\
\hline & 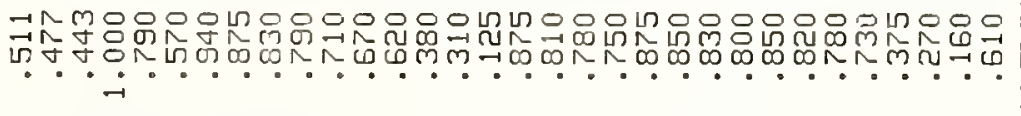 \\
\hline & 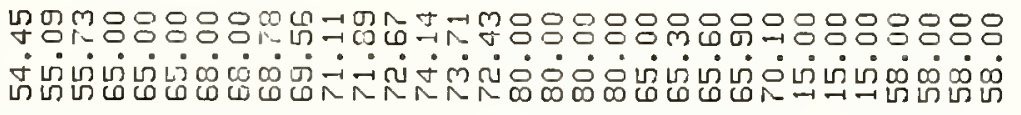 \\
\hline & 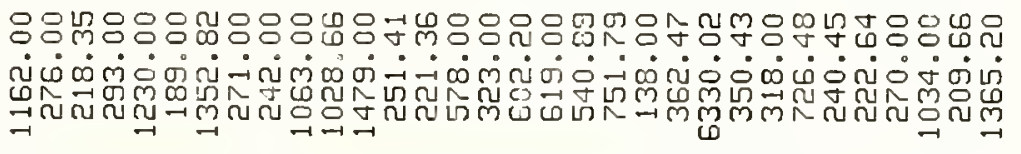 \\
\hline & 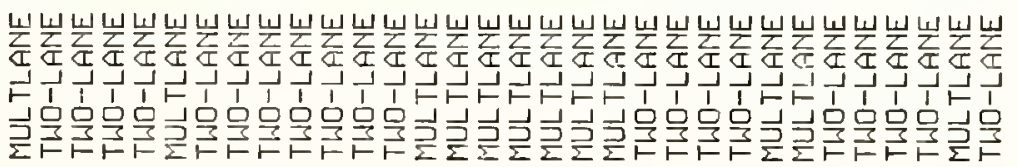 \\
\hline 1 & $+\stackrel{\infty}{\sim} \infty$ o \\
\hline
\end{tabular}




\begin{tabular}{|c|c|}
\hline 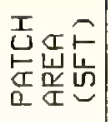 & 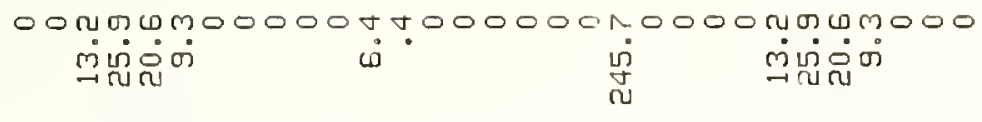 \\
\hline I & 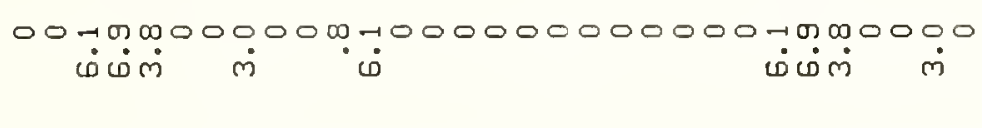 \\
\hline 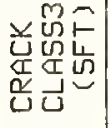 & 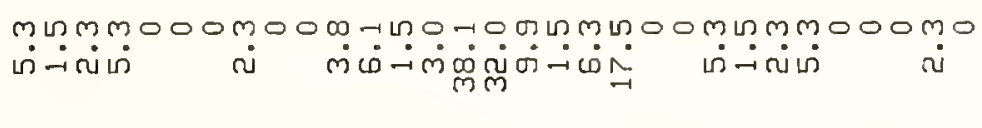 \\
\hline 4 & 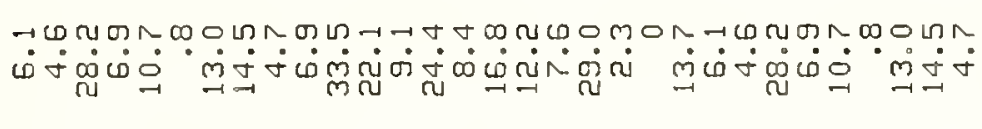 \\
\hline$u$ & 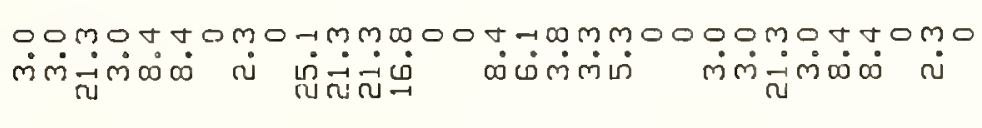 \\
\hline $\begin{aligned} \\
\frac{2}{2} \\
\end{aligned}$ & 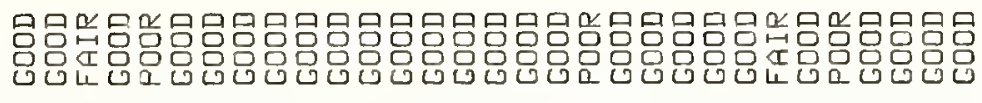 \\
\hline 识 & 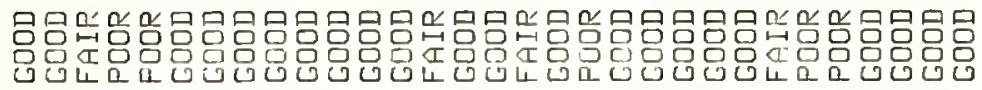 \\
\hline 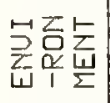 & 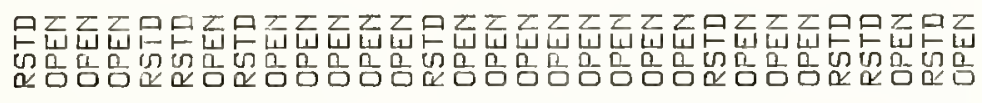 \\
\hline & 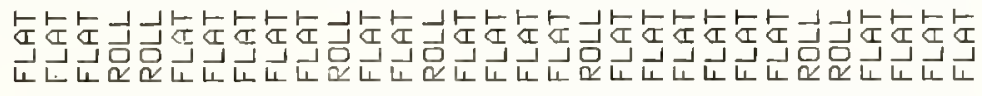 \\
\hline 点 & 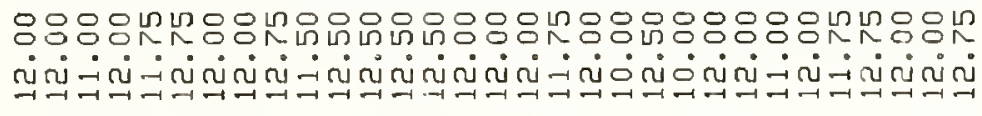 \\
\hline 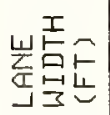 & 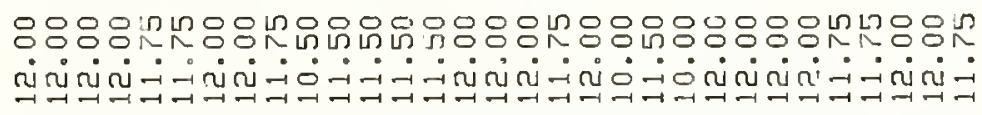 \\
\hline 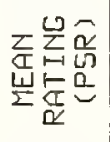 & 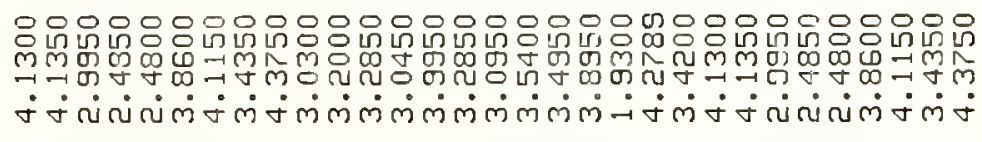 \\
\hline 星产点员 & 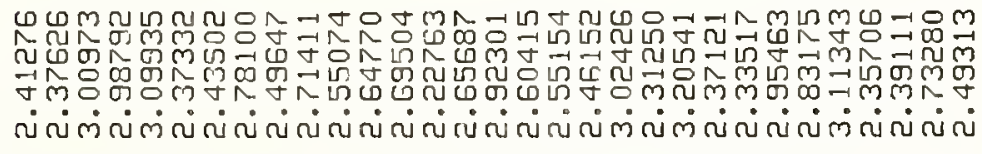 \\
\hline Шे & 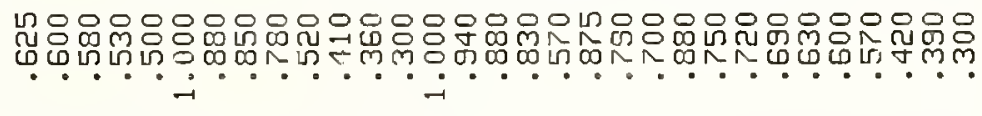 \\
\hline & 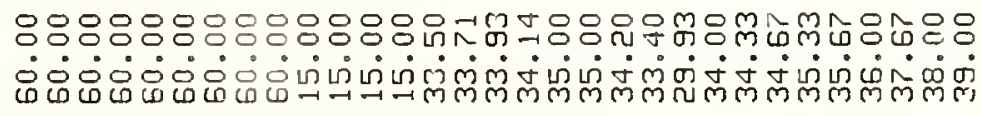 \\
\hline$\frac{\Sigma}{\frac{\Sigma}{\alpha}}$ & 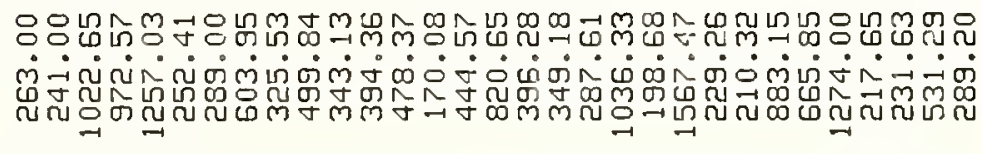 \\
\hline$\stackrel{\substack{\omega \\
\frac{\alpha}{2}}}{\vdash}$ & 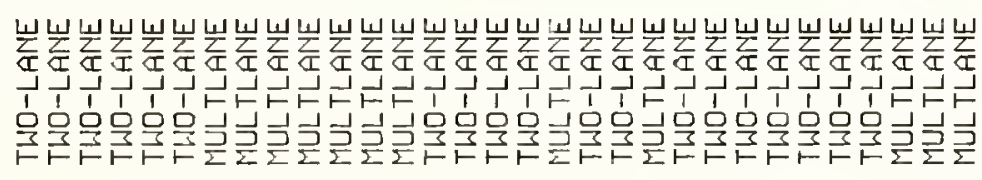 \\
\hline 占矛是 & 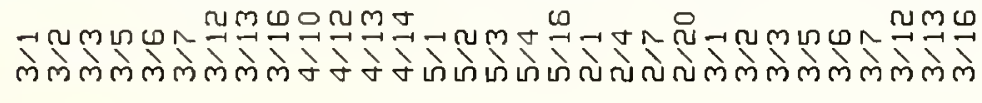 \\
\hline
\end{tabular}


000700000000000000000000000000000100000000 兵

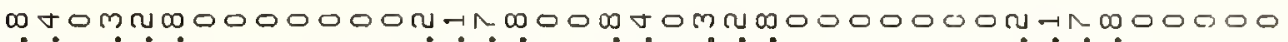

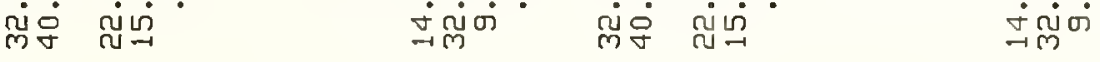

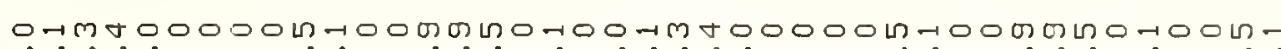
ம்றூن்

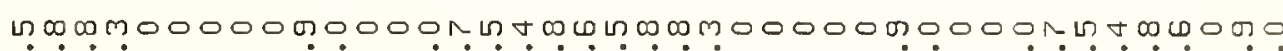

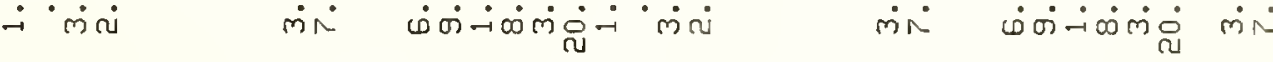

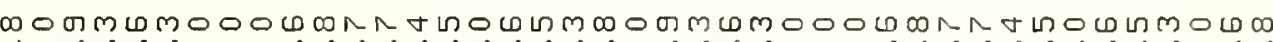

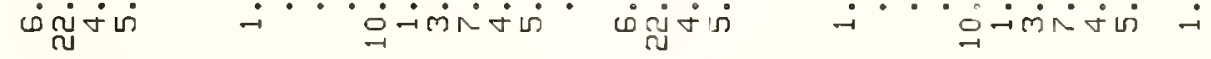

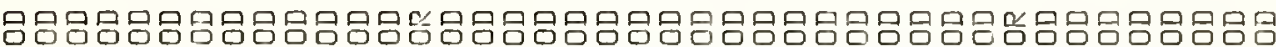

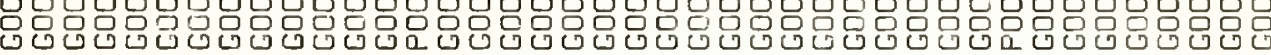

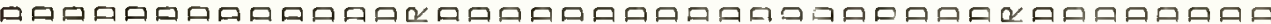

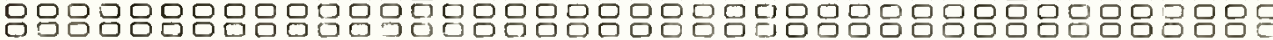

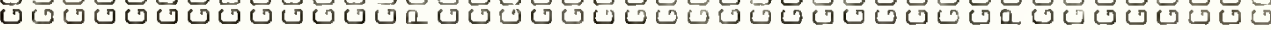

Ю元完

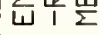
岩岁造 ₹ow

U⼯ 느늠 岀宁是 山吉。 近是出

远是会 吉何 $\sum \frac{I}{\alpha}$

몽 玹 늘 녿은

先 需

맘른 品岂し

U 泣衣的 ○.

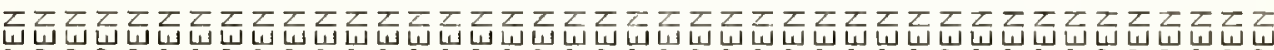

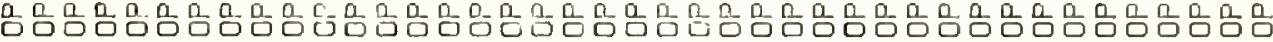

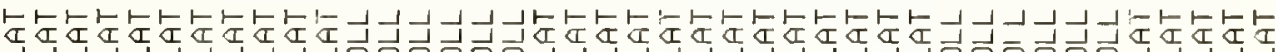

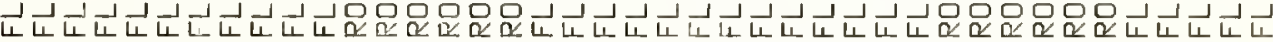

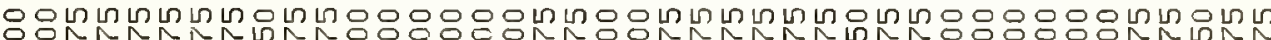
- . - . . . . . . .

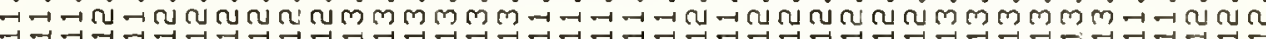
은ำம

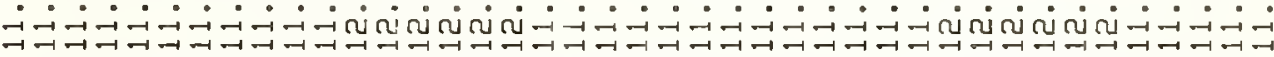
๓

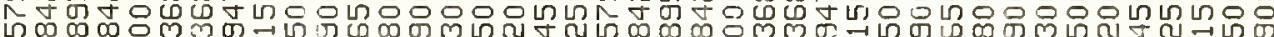

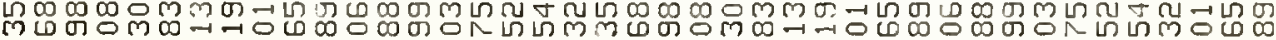

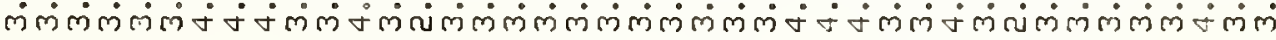

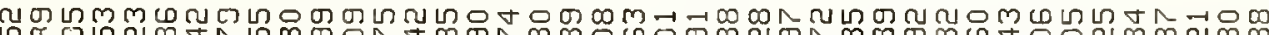

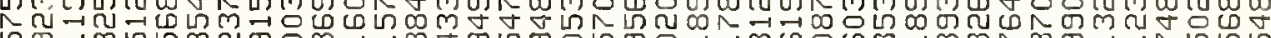

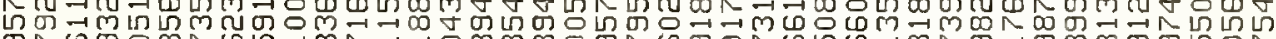
のハ

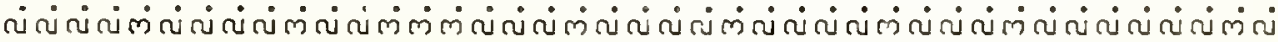

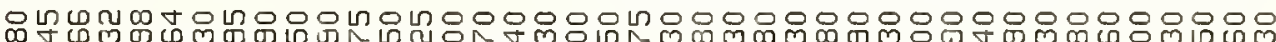

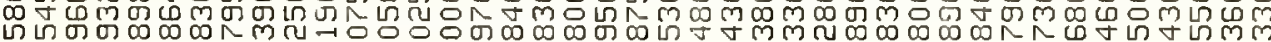

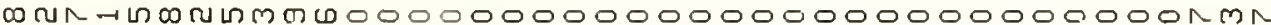
円்றம்

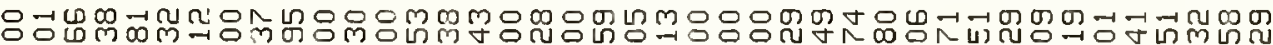

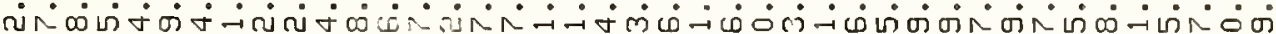

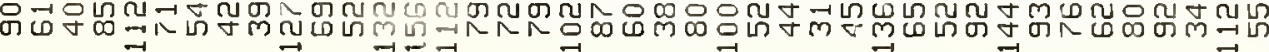

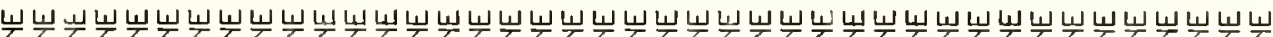

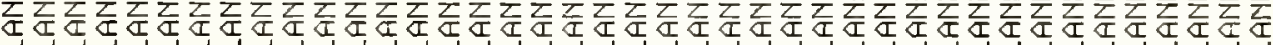

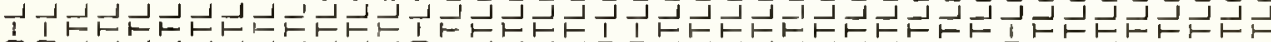

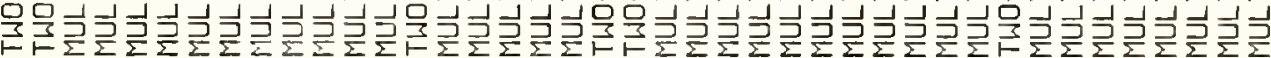
寸 $\rightarrow \sigma 0$

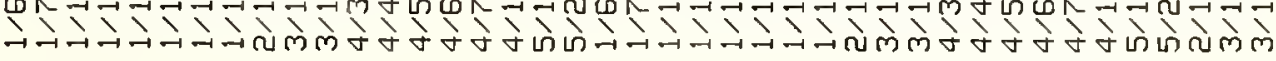




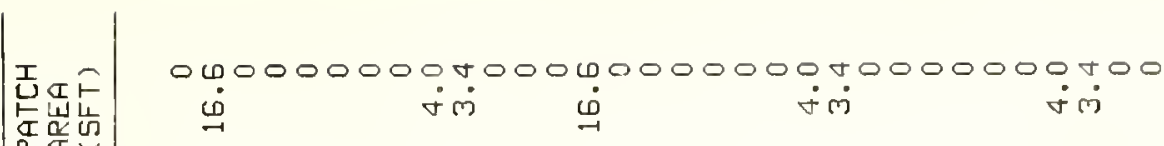

00000000000000000000000000000000

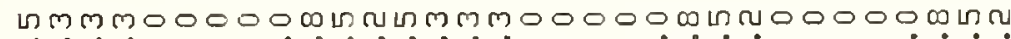

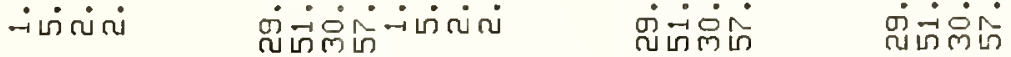

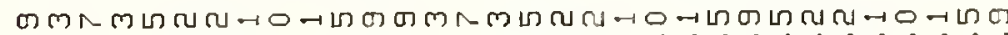

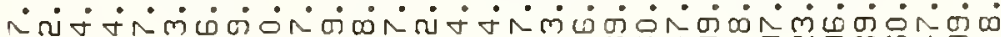
तี

ณம ம

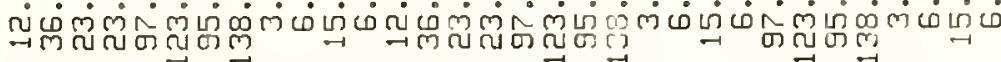

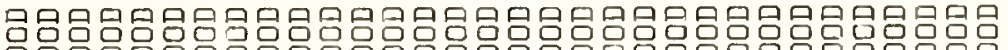

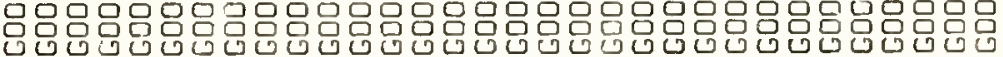

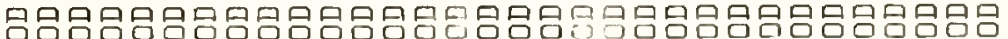

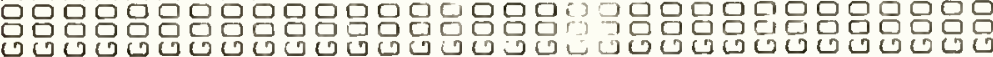

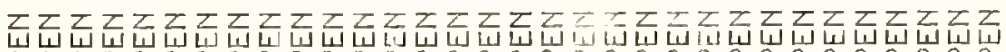

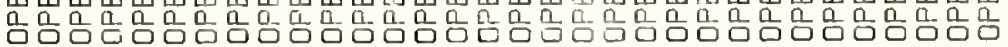

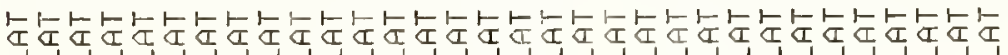

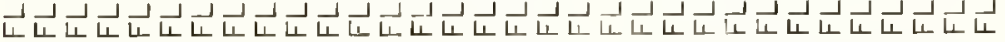

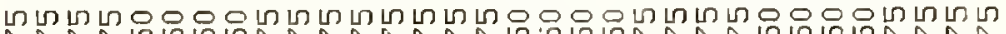

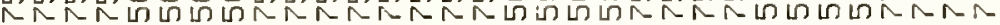

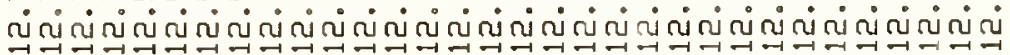
เท็น ภ

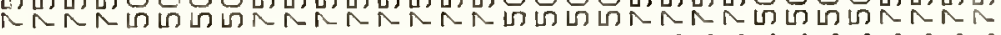

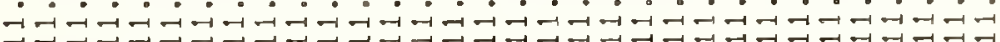
ช

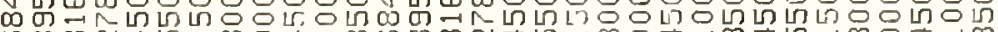

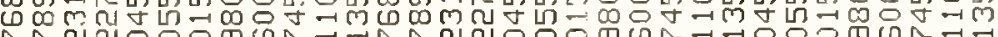

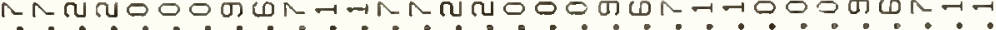

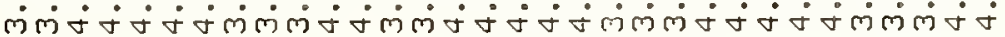

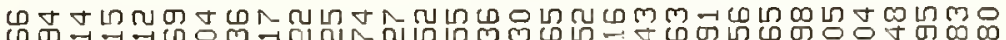
Оำ-

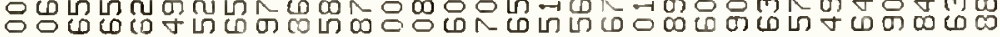

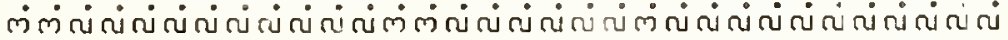

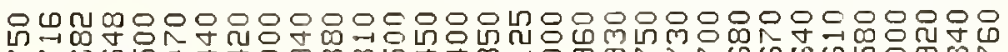

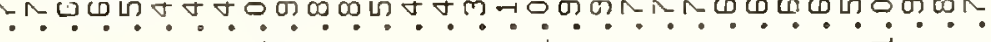

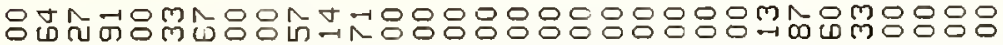

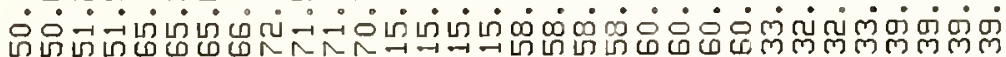

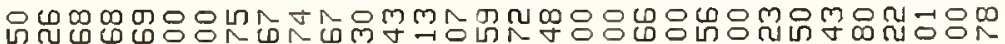

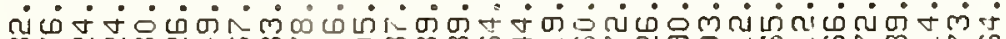

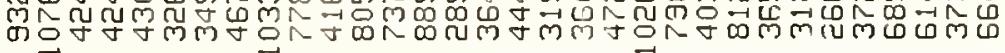

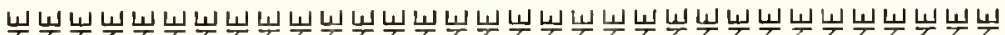

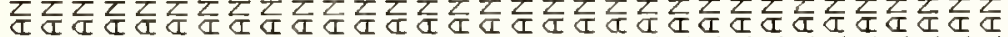

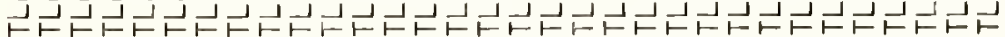

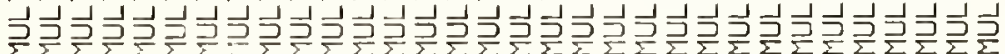


Table D8: Properties of PSI Models, Flexible Pavements

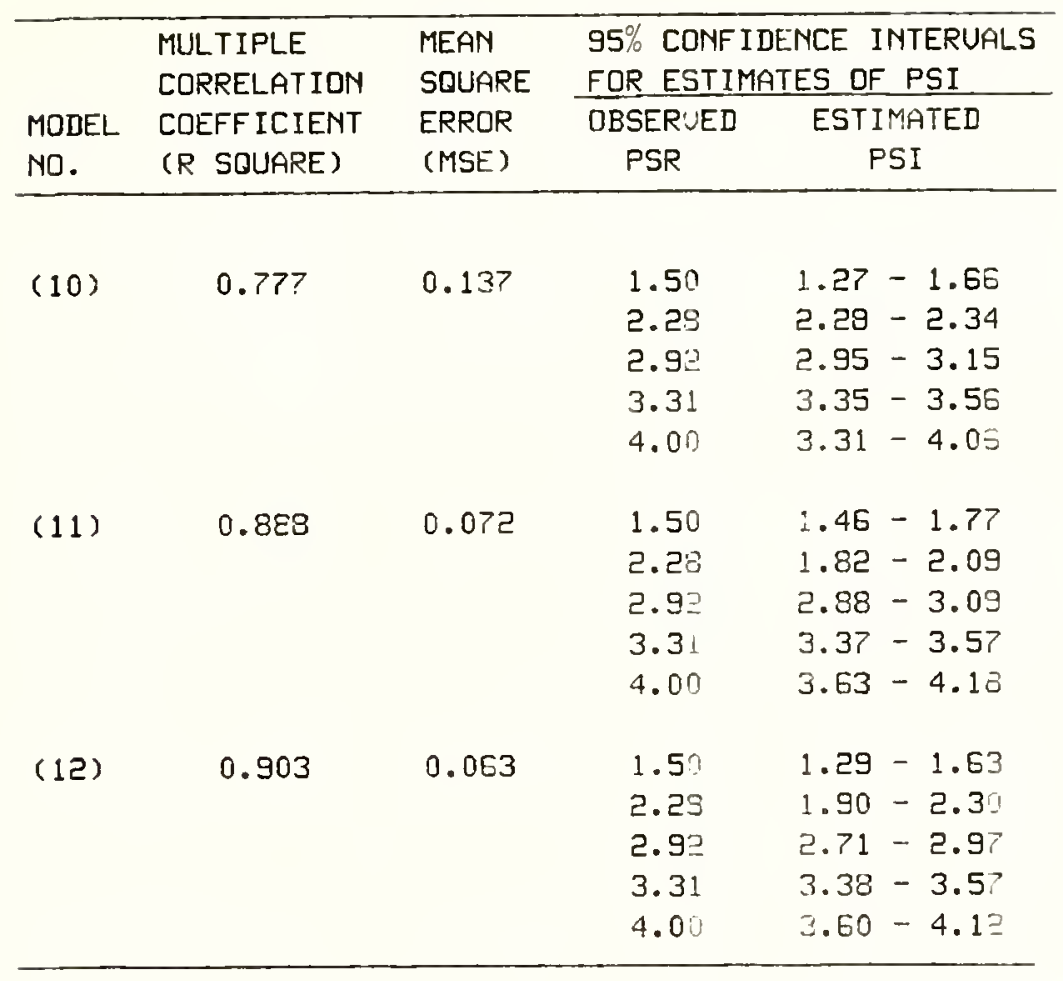


Table 09: Properties of PSI Models, Overlay Pavements

\begin{tabular}{|c|c|c|c|c|}
\hline \multirow[b]{2}{*}{$\begin{array}{l}\text { MODEL } \\
\text { MO. }\end{array}$} & \multirow{2}{*}{$\begin{array}{l}\text { MULT IPLE } \\
\text { CORRELATION } \\
\text { COEFF ICIENT } \\
\text { (R SQUARE) }\end{array}$} & \multirow{2}{*}{$\begin{array}{l}\text { MEAN } \\
\text { SOUARE } \\
\text { ERROR } \\
\text { (MSE) }\end{array}$} & \multicolumn{2}{|c|}{$\begin{array}{l}95 \% \text { CONF IDENCE INTERUALS } \\
\text { FOR ESTIMATES OF PSI }\end{array}$} \\
\hline & & & $\begin{array}{l}\text { OBSERUED } \\
\text { PSR }\end{array}$ & $\begin{array}{l}\text { ESTIMATED } \\
\text { PSI }\end{array}$ \\
\hline (13) & 0.700 & 0.139 & $\begin{array}{l}1.93 \\
2.48 \\
3.05 \\
3.90 \\
4.28\end{array}$ & $\begin{array}{l}2.60-2.91 \\
2.92-3.18 \\
3.17-3.40 \\
3.76-4.00 \\
4.17-4.54\end{array}$ \\
\hline$(14) * *$ & 0.915 & 0.043 & $\begin{array}{l}1.93 \\
2.48 \\
3.05 \\
3.90 \\
4.28\end{array}$ & $\begin{array}{l}1.67-2.13 \\
2.35-2.73 \\
3.43-3.61 \\
3.89-4.20 \\
4.21-4.46\end{array}$ \\
\hline$(15) *$ & 0.935 & 0.034 & $\begin{array}{l}1.93 \\
2.48 \\
3.05 \\
3.90 \\
4.28\end{array}$ & $\begin{array}{l}1.68-2.10 \\
2.30-2.64 \\
2.92-3.20 \\
3.82-4.09 \\
4.21-4.42\end{array}$ \\
\hline
\end{tabular}

* pauements treated as flexible for the MEASUREMENT OF CRACKS

* pavements tReated as rigid for the MEASUREMENT OF CRACKS 
Table D10: Properties of PSI Models, JRC Pavements

\begin{tabular}{|c|c|c|c|c|}
\hline \multirow{3}{*}{$\begin{array}{l}\text { MODEL } \\
\text { NO. }\end{array}$} & \multirow{2}{*}{$\begin{array}{l}\text { MULTIPLE } \\
\text { CORRELATION } \\
\text { COEFFICIENT }\end{array}$} & \multirow{2}{*}{$\begin{array}{l}\text { MEAN } \\
\text { SQUARE } \\
\text { ERROR }\end{array}$} & \multicolumn{2}{|c|}{$\begin{array}{l}95 \% \text { CONFIDENCE INTERUALS } \\
\text { FOR ESTIMATES OF PSI }\end{array}$} \\
\hline & & & OBSERUED & ESTIMATED \\
\hline & ( $R$ SDUARE) & (MSE) & PSR & PSI \\
\hline \multirow[t]{5}{*}{ (16) } & 0.567 & 0.060 & 2.99 & $3.00-3.32$ \\
\hline & & & 3.30 & $3.26-3.48$ \\
\hline & & & 3.65 & $3.25-3.48$ \\
\hline & & & 3.84 & $3.59-3.75$ \\
\hline & & & 4.19 & $4.03-4.38$ \\
\hline \multirow[t]{5}{*}{ (17) } & 0.902 & 0.016 & 2.99 & $2.81-3.17$ \\
\hline & & & 3.30 & $3.23-3.42$ \\
\hline & & & 3.65 & $3.56-3.73$ \\
\hline & & & 3.84 & $3.79-3.87$ \\
\hline & & & 4.19 & $4.02-4.23$ \\
\hline
\end{tabular}

Table D11: Properties of PSI Models, CRC Pavements

\begin{tabular}{|c|c|c|c|c|}
\hline \multirow[b]{2}{*}{$\begin{array}{l}\text { MODEL } \\
\text { NO. }\end{array}$} & \multirow{2}{*}{$\begin{array}{l}\text { MUL TIPLE } \\
\text { CORRELATION } \\
\text { COEFFICIENT } \\
\text { (R SQUARE) }\end{array}$} & \multirow{2}{*}{$\begin{array}{l}\text { MEAN } \\
\text { SQUARE } \\
\text { ERROR } \\
\text { (MSE) }\end{array}$} & \multicolumn{2}{|c|}{$\begin{array}{l}\text { 95\% CONF IDENCE INTERUALS } \\
\text { FOR ESIIMAIES OF PSI }\end{array}$} \\
\hline & & & $\begin{array}{l}\text { ODSERIJED } \\
\text { PSR }\end{array}$ & $\begin{array}{l}\text { ESTIMATED } \\
\text { PSI }\end{array}$ \\
\hline (18) & 0.455 & 0.021 & $\begin{array}{l}3.60 \\
3.79 \\
3.93 \\
4.11 \\
4.23\end{array}$ & $\begin{array}{l}3.69-3.87 \\
3.63-3.85 \\
3.96-1.66 \\
4.01-4.15 \\
4.01-4.14\end{array}$ \\
\hline (19) & 0.967 & 0.002 & $\begin{array}{l}3.60 \\
3.79 \\
3.98 \\
4.11 \\
4.23\end{array}$ & $\begin{array}{l}3.47-3.56 \\
3.76-3.86 \\
3.95-4.02 \\
4.07-4.16 \\
4.19-4.27\end{array}$ \\
\hline
\end{tabular}


APPENDIX E

Deflection Studies 


\section{APPENDIX E}

Table E1: Properties of 46 Test Sections

\begin{tabular}{|c|c|c|c|c|c|c|c|}
\hline \multirow{2}{*}{$\begin{array}{l}\text { TEST } \\
\text { SECT ION }\end{array}$} & \multirow{2}{*}{$\begin{array}{l}\text { TYPE DF } \\
\text { PAUEMENT }\end{array}$} & \multirow{2}{*}{$\begin{array}{l}\text { ROUGHNESS } \\
\text { GROUP }\end{array}$} & \multirow{2}{*}{$\begin{array}{l}\text { SOIL } \\
\text { TYPE }\end{array}$} & \multirow{2}{*}{$\begin{array}{l}\text { EFFECTIUE } \\
\text { THICKNESS }\end{array}$} & \multirow{2}{*}{$\begin{array}{l}\text { TRAFF IC } \\
\text { INTENSITY }\end{array}$} & \multicolumn{2}{|c|}{ MEASURED } \\
\hline & & & & & & FALL & SPRG \\
\hline $1 / 1$ & CRC & SMOOTH & POOR & $>9$ INCHES & $>3500$ UPD & YES & YES \\
\hline $1 / 2$ & CRC & SMODTH & POOR & $>9$ INCHES & $>3500$ UPD & YES & YES \\
\hline $1 / 5$ & FLEXIBLE & AUERACE & G0DD & $>9$ INCHES & $\leq 3500$ UPD & YES & YES \\
\hline $1 / 6$ & JRC & AUERAGE & GOOD & :O INCHES & $>3500$ UPD & YES & YES \\
\hline $1 / 8$ & DUERLAY & AUERAGE & POO? & 9 INCHES & $>3500$ UPD & YES & YES \\
\hline $1 / 9$ & OUERLAY & SMOOTH & POOR & $>9$ INCHES & $>3500$ UPD & YES & YES \\
\hline $1 / 10$ & OUERLAY & SMOOTH & POOR & $>9$ INCHES & $\$ 3500$ UPD & YES & YES \\
\hline $1 / 11$ & OUERLAY & ROUCH & POOR & $>9$ INCHES & $\$ 3500$ UPD & YES & NO \\
\hline $1 / 12$ & FLEXIBLE & AUERAGE & GOOD & $\leq 9$ INCHES & $\leq 3500$ UPD & YES & YES \\
\hline $1 / 13$ & FLEXIBLE & ROUGH & COOD & $\leq 9$ INCHES & $\leq 3500$ UPD & YES & YES \\
\hline $1 / 14$ & JRC & SMOOTH & GOOD & $>9$ INCHES & $>3500$ UPD & YES & YES \\
\hline $1 / 15$ & $J R C$ & AUERAGE & COOD & $>9$ INCHES & $>3500$ UPD & YES & YES \\
\hline $1 / 16$ & $J R C$ & AUERAGE & POOR & $>9$ INCHES & $>3500$ UFD & YES & YES \\
\hline $1 / 17$ & JRC & SMOOTH & POOR & $>9$ INCHES & $>3500$ UPD & YES & YES \\
\hline $1 / 20$ & FLEXIBLE & AUERAGE & POOR & $\leq 9$ INCHES & $\$ 3500$ UPD & YES & YES \\
\hline $2 / 3$ & FLEXIBLE & SMOOTH & POOR & $>9$ INCHES & $\$ 3500$ UPD & NO & YES \\
\hline $2 / 6$ & FLEXIBLE & AUERAGE & GOOD & $\leq 9$ INCHES & $\leq 3500$ UPD & YES & YES \\
\hline $2 / 7$ & OUERLAY & SMOOTH & GOOD & $\leq 9$ IMCHES & $>3500$ UPL & $y=5$ & YES \\
\hline $2 / 8$ & C.RC & AUERAGE & GOOD & $>9$ INCHES & $>3500$ UPU & YES & YES \\
\hline $2 / 10$ & $\mathrm{CRC}$ & AUERAGE & GOOD & $>9$ IMCHES & $>3500$ UPD & YES & Y'ES \\
\hline $2 / 11$ & CRC & AUERAGE & FOOR & $>9$ IMCHES & $>3500$ UPD & YES & YES \\
\hline $5 / 20$ & OUERLAY & AUERAGE & GOOD & $\leq 9$ INCHES & $\leq 3500$ UPD & YES & YES \\
\hline $3 / 1$ & OUERLAY & SMOOTH & GODD & >9 INCHES & $>3500$ UPD & YES & YES \\
\hline $3 / 2$ & OUERLAY & SMOCTH & GOOD & $>9$ INCHES & $>3500$ UPD & YES & YES \\
\hline $3 / 3$ & OUERLAY & AUERAGE & POOR & $>9$ INCHES & $\leq 3500 \quad U P D$ & YES & YES \\
\hline $4 / 1$ & FLEXIBLE & AUERAGE & POOR & $\leq 9$ INCHES & S350u UPD & YES & YES \\
\hline $4 / 3$ & $\mathrm{JRC}$ & SMOOTH & POOR & IS INC'HCS & $>3500$ UPD & YES & YES \\
\hline $4 / 4$ & $J R C$ & SMOOTH & FOOR & Y9 INCIAES & $\$ 3500$ UPD & YES & YES \\
\hline $4 / 6$ & JRC & AUERAGE & POOR & 9 INCHES & $>3500$ UPI & YES & YES \\
\hline $4 / 9$ & FLEXIBLE & AUERAGE & POOR & \S INCHES & $>3500$ UPD & nos & YES \\
\hline $4 / 10$ & OUERLAY & AUERAGE & POOR & $\leq 9$ INCHES & $>3500$ UPD & YES & YES \\
\hline $4 / 11$ & $J R C$ & AUERAGE & POOR & $\$ 9$ INCHES & $\$ 3500$ UPD & $Y=S$ & YES \\
\hline $4 / 12$ & DUERLAY & AUERACE & POOR & $\leq 9$ INCHES & $\$ 3500$ UPI & $Y=3$ & YES \\
\hline $4 / 13$ & DUERLAY & SMOOTH & POOR & $\leq 9$ INCHES & $\leq 3500$ UPD & YES & YES \\
\hline $4 / 14$ & OUERLAY & AUERAGE & GOOD & >9 INCHES & $>3500$ UPD & YES & YES \\
\hline $5 / 3$ & OUERLAY & AUERAGE & POOR & $>9$ INCHES & $\leq 3500$ UP Li & NO & YES \\
\hline $5 / 7$ & FLEXIBLE & ROUGH & GOOD & $\leq 9$ INCHES & $\$ 3500$ UPD & YES & YES \\
\hline $5 / 8$ & FLEXIBLE & SMOOTH & POOR & $\$ 9$ INCHES & $\$ 3500$ UPD & YES & YES \\
\hline $5 / 10$ & FLEXIBLE & AUERACE & COOD & $\leq 9$ INCHES & $\leq 3500$ UPD & YES & YES \\
\hline $5 / 11$ & FLEXIBLE & SMOOTH & GOOD & :9 INCHES & $>3500$ UPD & YES & YES \\
\hline $5 / 14$ & FLEXIBLE & SMOOTH & GOOD & $\leq 9$ INCHES & $\$ 3500$ UPD & YES & YES \\
\hline $5 / 15$ & FLEXIBLE & ROUGH & POOR & $\leq 9$ INCHES & $\triangle 3500$ UPD & YES & YES \\
\hline $5 / 17$ & FLEXIBLE & ROUGH & POOR & \$9 INCHES & S3500 UPD & YES & YES \\
\hline $5 / 18$ & OUERLAY & AUERAGE & POOR & $>9$ INCHES & $>3500$ UPD & YES & YES \\
\hline $5 / 19$ & JRC & AUERAGE & POOR & $\$ 9$ INCHES & $>3500$ UPD & YES & NO \\
\hline $5 / 20$ & $J P C$ & AUERAGE & POOR & $\leq 9$ INCHES & $>3500$ UPI & YES & YES \\
\hline
\end{tabular}


돔

जी तथ का एव लि

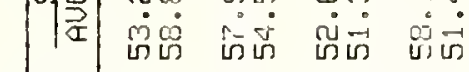

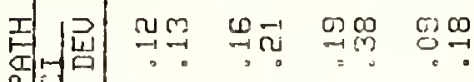

맵ำ

或语

논원은

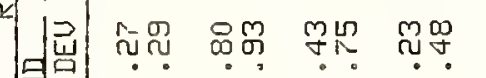

貝星

ก

ग

잉

혀 늠으.

ณี ณูำ

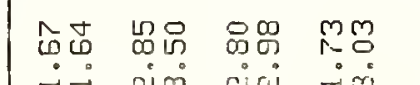

ข

ก ชั

$\therefore$ ni०

ब नm

ก. ำ

म

乌 ఫ吅㟔岩

$i_{\rightarrow \rightarrow-1}=-1$

$\because$ 의

กี

|

on t

เป็น ญ๋

mos

min

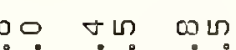

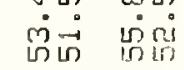

岃

$\exists \infty$

豈得

ถิำ

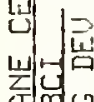

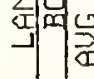

周岂

य $\mathrm{m}$

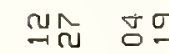

(1)

$0 ?$

$\mp$

กิ.

กับ ถึ

กิ่

-

ตำ

ㅁํㅇ

$\vec{a} \rightarrow \mathfrak{7}$

ติต

$\infty 100$

บ่

圆

$m$

MN WD NM OO

$\because m$

$\rightarrow$ オ

范 กin

(20)

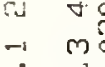

$+?$

(1) जुन हो

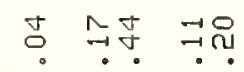

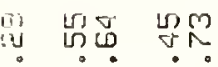

m

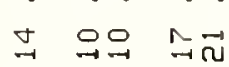

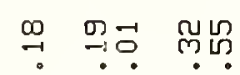

กิ

$\dot{-} \dot{-} \dot{i}$

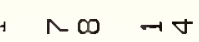

ते लं் लंखे

- mín $\infty \circ$

궁

UN mष

เ์

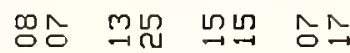

लं

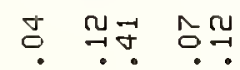

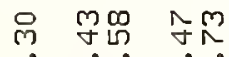

守守邑

岀

눜

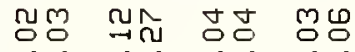

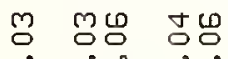

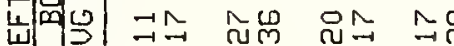

을

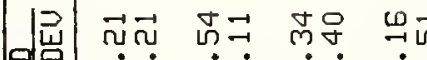

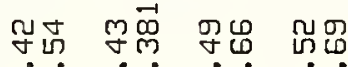

․ำ ํㅜㅇำ

ఫ $\quad 0$

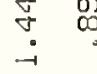

()

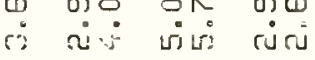

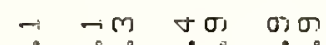

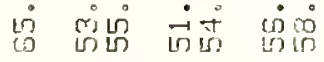

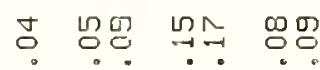

ญ ณัต ल

i)

乌.

त

$\stackrel{\infty}{\rightarrow-1}$

ญุ

ल

ए.

in

今。

$\infty$ の० $\forall \infty$

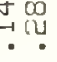

\๐

$\because$

?

.

ตำ

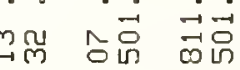

- थं

$m$ ח

m

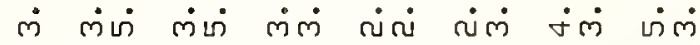

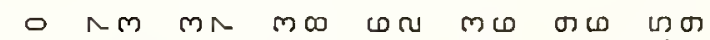

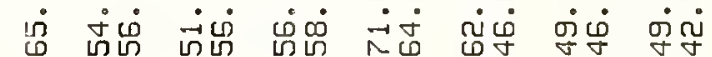

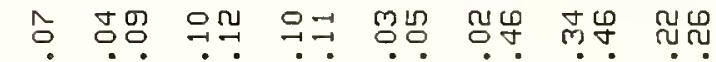

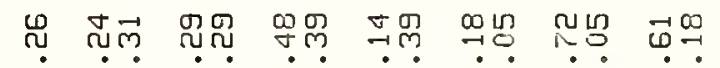

ت

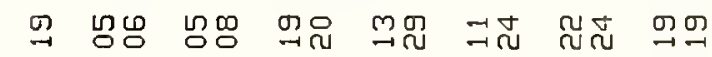

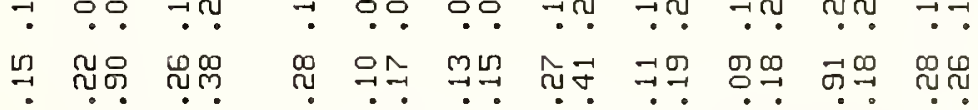

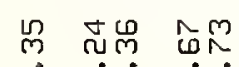

$\because$

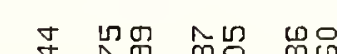

以

$\because \because$ ดีฺ ญ ญ ญ
依

-ं ते ते

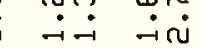

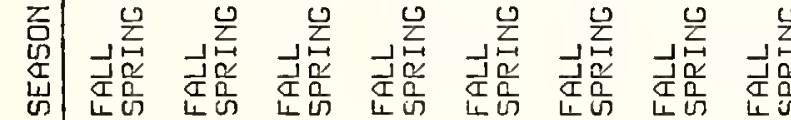

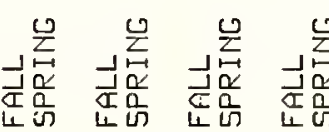

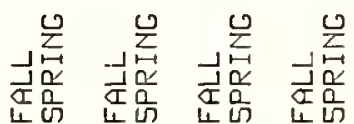

严竞 鸹寍 욤

m

0

ì

m

i

$\vec{\xi}$

蒿哭点 


\begin{tabular}{|c|c|c|c|c|c|c|c|c|c|c|c|c|c|c|c|}
\hline | & 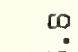 & ? & $\omega \omega$ & ญ. & ? ת ח & $\omega$ \% & $\because m$ & $\cos$ & ? ? & เก & $\because m$ & $\varphi$ & $\Upsilon \infty$ & ! & 0 \\
\hline 口㟒 & in & $m \infty$ & "ن & $\omega$ & & $\sigma \widetilde{\sigma}$ & $\operatorname{lin}$ & ن் & $\omega$ & טั & & $n N$ & $+\pi$ & $m$ & $m \dot{\sigma}$ \\
\hline 药化 & $\infty$ & $\checkmark \omega$ & บ O & ? & $\because 0$ & $\because \infty$ & ? & $\rho_{0}^{8}$ & 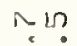 & D & ต & יחים & เว $\mathrm{m}$ & $\infty$ & ת \\
\hline & $\stackrel{.}{\omega}$ & $\vec{\Lambda} \mathscr{N}$ & $\stackrel{\omega}{\sim}$ & $\aleph$ & $\stackrel{M}{M}$ & in & $\stackrel{\sim}{\sim} \stackrel{0}{n}$ & 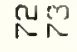 & 岂 & $M N$ & $\Omega \Omega$ & $\vec{n}-\vec{n}$ & $\stackrel{\sim}{N}$ & $\vec{N}$ & JR \\
\hline & $\stackrel{\text { ก }}{\circ}$ & ஏ음 & 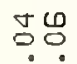 & $\stackrel{\infty}{\infty}$ & $\vec{\circ}$ & 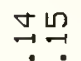 & ป见 & Фீர & 음 & Jே & $g \sigma$ & 동 & $\mathscr{O B}$ & !n & ญ용 \\
\hline 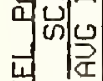 & $\stackrel{\mathscr{O}}{.}$ & 욤용 & 능요. & $\stackrel{0}{-1}$ & 苟 & 里芯 & 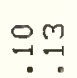 & & $\underset{.1}{\infty}$ & 옹묘. & $9 \Omega$ & 믐 & $\begin{array}{l}\Rightarrow \\
\Rightarrow\end{array}$ & 9 & 㝵气 \\
\hline & n! & ณ̛ & 잉 & 巳ֶ: & Б). & (r) & 엉음 & ?ח & 崖员。 & ִư & 西学 & ㅁํㅇ & ญญ & $\ddot{\circ}$ & $c$ \\
\hline & $\Rightarrow$ & $\stackrel{r}{\sim} \underset{-1}{\infty}$ & $\stackrel{0}{\circ-1}$ & $\stackrel{0}{\circ}$ & Б0 & 몸요 & $\rightarrow \square$ & $\underset{-1 M}{ }$ & $y_{n \rightarrow-1}$ & $g m$ & $\underset{-1}{T}$ & $\stackrel{M}{\longrightarrow}$ & 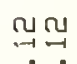 & $g_{-1}$ & \\
\hline & $\stackrel{\square}{\square}$ & \begin{tabular}{l}
$m$ \\
$\rightarrow n$ \\
\hdashline
\end{tabular} & $\underset{\rightarrow-1}{m}$ & $\stackrel{\bullet}{\because}$ & Mo & ญำ & $\underset{?}{m} \stackrel{n}{\because}$ & $\stackrel{\leftrightarrow}{\longrightarrow}$ & กิญ & $\because \stackrel{\square}{\because}$ & $\stackrel{\oplus}{\hookrightarrow}$ & 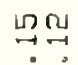 & $\stackrel{\ln m}{\longrightarrow}$ & $\stackrel{\mathscr{D}}{\mathrm{I}}$ & \\
\hline & $\stackrel{m}{\omega}$ & ติ? & ஸिあ & 䍐 & 슴요 & 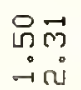 & 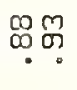 & 元员 & $\begin{array}{l}\infty \\
00 \\
0\end{array}$ & & 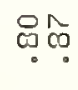 & ॠळ & వె & $\vec{b}$ & \\
\hline & $\because \infty$ & שִ & 10 & 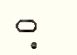 & -1 & ฯ & ऽ & & $00 ?$ & $\Lambda \nabla$ & $\omega$ & $\theta$ & H & (1) & \\
\hline & $\begin{array}{ll}0- \\
0-1\end{array}$ & $\begin{array}{l}\omega \infty \\
\infty m\end{array}$ & $-(1)$ & $\underset{\substack{n \\
\rightarrow-1 \\
\sigma}}{ }$ & 10 & $\mathrm{~mm}$ & $\begin{array}{l}\infty \\
01 \\
0 \\
0\end{array}$ & & 3 & 30 & & $\neg$ & $=0$ & $n$ & : \\
\hline & $\dot{0}$ & $\stackrel{\infty}{m}$ & $\therefore-1$ & $\dot{0}$ & & $\dot{0}$ & $\therefore i$ & & $\dot{\vec{m}}$ & & $\dot{v} \dot{0}$ & यंณ & 14 & $\dot{\Omega}$ & \\
\hline & 공용 & பீ口 & 농ํㅇㅇ & $\stackrel{\curvearrowright}{\neg}$ & تేత & ஜூ & $\circlearrowleft \mathscr{0}$ & 임 & $\begin{array}{l}\exists \mathscr{0} \\
\because 0\end{array}$ & $\stackrel{\circ}{=1}$ & 品 & 品 & 몯 & 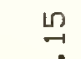 & m \\
\hline & 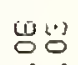 & fou & ரீல & ป & 吉 & Фి & ๑ே & $\simeq \sigma_{1}$ & g용 & 4. & மㄷㅇㅇ & $\stackrel{\infty}{0} 0$ & g & 品 & \\
\hline & ญ ऽ & 푱 & $\mathrm{O}^{-1} \mathrm{~g}$ & $\stackrel{n}{0}$ & $0 \overrightarrow{0}$ & ญ & 90 & i & $M \varphi$ & エ & $m s$ & $m \cap$ & đg & صூ & \\
\hline & $\ddot{\circ} \rightrightarrows$ & g & $\tilde{\Delta} \simeq$ & g & ఫே & 可 & $\exists$ & $m$ & $\underset{g}{\operatorname{gn}}$ & $1 \Omega$ & $\subseteq$ & $1-1$ & $\cong$ & 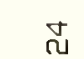 & \\
\hline & 요 & $\underset{\rightarrow}{M} \mathbb{M}$ & ğ & 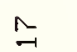 & 용용 & ח & 믐 & 옹 & $\stackrel{\infty}{\sim} \underset{\sim}{\Omega}$ & $\simeq$ & MO & I & $\exists \subseteq$ & $\vec{\nabla}$ & \\
\hline & 识 & $\stackrel{0}{\circ \sigma}$ & $\begin{array}{l}\forall 0 \\
0 \infty\end{array}$ & $\dddot{M}$ & $A \rightarrow$ & חָ & $\hat{\wedge}$ & & تี & $\stackrel{\infty}{\infty}$ & $\Sigma \widetilde{\infty}$ & 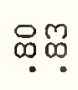 & ती. & $\stackrel{5}{\circ}$ & \\
\hline & 00 & $\because \sigma$ & & $\rightarrow$ & $\infty \nrightarrow$ & एव & 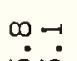 & & & $\omega \infty$ & ? & ? & $00 \mathrm{~m}$ & क? & ? \\
\hline & תו & L & $\omega \sigma$ & $\stackrel{\circ}{10}$ & & ฯ & เก & & & & & QN & mo & $\nabla$ & \\
\hline & סீ & 元 & $\dot{\infty} \dot{\sim} \dot{\sim}$ & $\ddot{n}$ & ○் & $\dot{\leftarrow}$ & $\dot{n} \dot{\sim}$ & N & $\stackrel{\sim}{\sim}$ & & $\ddot{\sim} \dot{\infty}$ & $\dot{\Omega} \dot{\Omega}$ & $\dot{\sim} \dot{N}$ & هi & \\
\hline & Mூ & $\mathscr{B} \mathscr{\circ}$ & மூ勺 & $\stackrel{\Xi}{\unlhd}$ & -19 & $\mathscr{0} \stackrel{0}{\circ}$ & $\mathscr{\circ} \stackrel{\circ}{\circ}$ & o & $\stackrel{\text { g }}{\circ}$ & 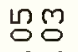 & $\stackrel{0}{\circ}$ & $\tilde{\Delta} \pm$ & 농 & $\stackrel{m}{\rightarrow}$ & \\
\hline & ¿\% & 밍 & むU & $\stackrel{\circ}{\circ}$ & ณ & ณ̃ & פே & g & $\mathscr{D}$ & & $\omega$ & $\stackrel{\infty}{\circ}=$ & 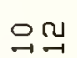 & ભ & \\
\hline & ญ & ญ® & ญ & m & $\overrightarrow{0}$ & MO & ஐす & MI & g & $-1 \mathrm{X}$ & $\because \Xi$ & M용 & 농 & 몽 & $\overrightarrow{0}$ \\
\hline 员 & 냉음 & $\stackrel{ }{\simeq}$ & $\tilde{\sigma}=$ & g) & 它 & $\pm \stackrel{\sim}{ \pm}$ & $\stackrel{\Perp}{\unlhd}$ & $\stackrel{M}{M}$ & & บ & $\stackrel{M}{ }=$ & $\exists \cong$ & 음으 & $\tilde{n}$ & ש \\
\hline & $\exists \pm$ & $m \Omega$ & の & 옹 & $\mathrm{Mn}$ & $\sim \infty$ & $\sim \infty$ & & & & & & 잉 & $\bar{m}$ & \\
\hline 证 & ำก & - & $\begin{array}{l}\text { 웅ㅇ } \\
\text { ㅁํ․ }\end{array}$ & 思 & ณొ & ญั & $\begin{array}{l}\text { पू } \\
\text { का }\end{array}$ & ư & 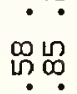 & 10 & $\stackrel{+\infty}{n}$ & 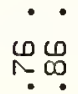 & 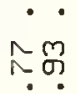 & $\vec{m}$ & 岇邑 \\
\hline 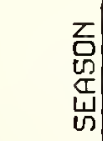 & 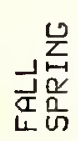 & 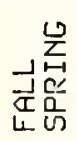 & 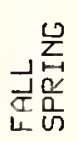 & 夏 & 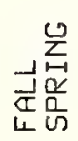 & 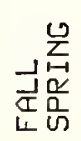 & 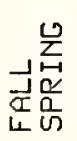 & 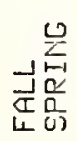 & 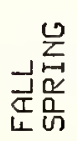 & 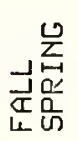 & 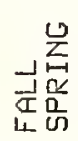 & 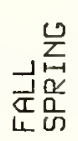 & 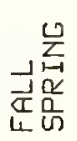 & 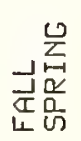 & 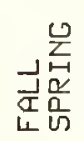 \\
\hline ज舟 & $\infty$ & \% & I & $\exists$ & 1 & ญิ & 1 & $?$ & & & & $\stackrel{m}{\rightarrow}$ & I & 3 & \\
\hline & $ન$ & $न$ &. & $\therefore$ & 7 & ญे & ले & ले & ले & & $\nabla$ & $\vec{v}$ & ने & in & 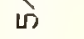 \\
\hline
\end{tabular}




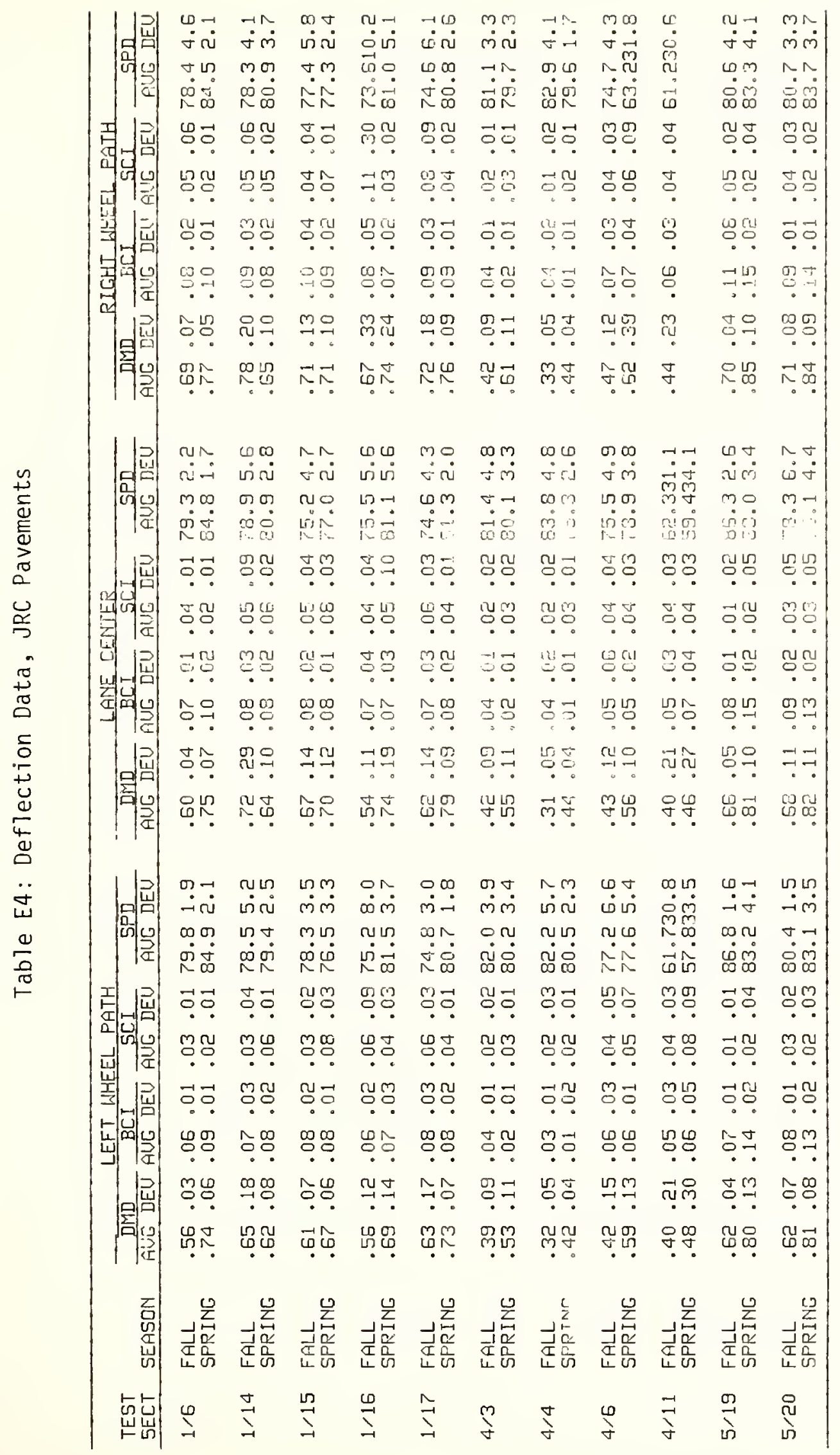




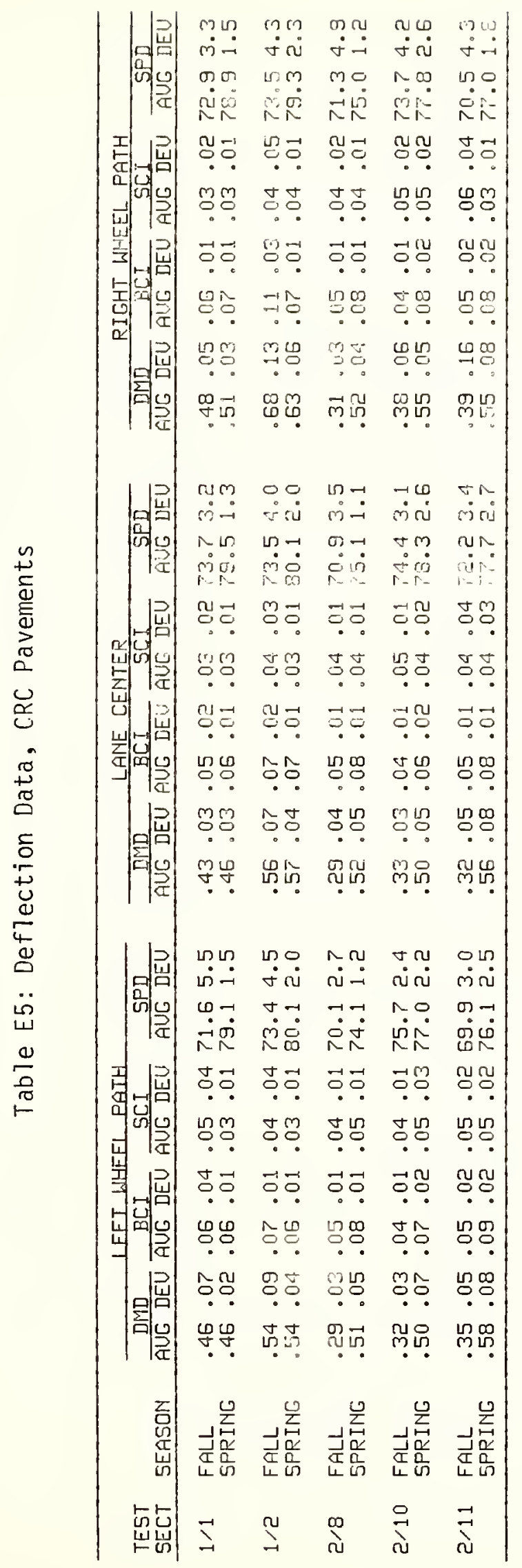


Table E6: Summary of ANOVA

(Log $\mathrm{S}^{2}$ by Test Sections and Wheel Paths)

\begin{tabular}{|c|c|c|c|}
\hline \multirow[b]{2}{*}{ PAUEMENTS } & \multicolumn{2}{|c|}{ LEUELS OF SIGNIF ICANCE FOR } & \multirow[b]{2}{*}{$R^{2}$} \\
\hline & $\begin{array}{c}\text { TEST } \\
\text { SECTIONS }\end{array}$ & $\begin{array}{l}\text { WHEEL } \\
\text { PATHS }\end{array}$ & \\
\hline \multicolumn{4}{|l|}{ FLEXIBLE } \\
\hline DMD & .001 & $.003 * * *$ & .939 \\
\hline$B C I$ & .001 & $.005 * * *$ & .973 \\
\hline SCI & .001 & $.001 * * *$ & .947 \\
\hline SPD & .001 & $.103 *$ & .751 \\
\hline \multicolumn{4}{|l|}{ DUERLAY } \\
\hline$\overline{D i t D}$ & .001 & .152 & .928 \\
\hline $\mathrm{BCI}$ & .001 & .3 .79 & .840 \\
\hline SCI & .001 & .161 & .939 \\
\hline SPD & .001 & $.037 *$ & .314 \\
\hline \multicolumn{4}{|l|}{$J R C$} \\
\hline DMD & .001 & $.102 *$ & .892 \\
\hline $\mathrm{BC} 1$ & .016 & $.017 * *$ & .671 \\
\hline SCI & .005 & .132 & .685 \\
\hline SPD & .001 & .196 & .856 \\
\hline \multicolumn{4}{|l|}{ CRC } \\
\hline DMD & .034 & $.056 *$ & .767 \\
\hline ECI & .083 & .604 &.$E 25$ \\
\hline SCI & .038 & .144 & .735 \\
\hline SPD & .676 & .331 & .363 \\
\hline
\end{tabular}

* significaitt at . 10 level

* Significant at .05 leUel

*** EIGIYIFICANT AT .01 LEUEL 
APPENDIX F

Skid Studies 
APPENDIX $F$

Table F1: Average Values of Skid Numbers of the 41 Test Sections

FLEXIBLE PAUEMENTS

DUERLAY PAUEMENTS

\begin{tabular}{|c|c|c|c|c|c|c|c|}
\hline $\begin{array}{l}\text { TEST } \\
\text { SECTION }\end{array}$ & SEASON & $\begin{array}{l}\text { SKID N } \\
\text { MEAN }\end{array}$ & $\begin{array}{r}\text { YUMEER } \\
\text { DEU }\end{array}$ & $\begin{array}{l}\text { TEST } \\
\text { SECTION }\end{array}$ & SEASON & $\begin{array}{l}\text { SKID } \\
\text { MEAN }\end{array}$ & $\begin{array}{r}\text { NUMBER } \\
\text { DEU }\end{array}$ \\
\hline $1 / 5$ & $\begin{array}{l}\text { FALL } \\
\text { SPRINC, }\end{array}$ & $\begin{array}{l}29.42 \\
=9.64\end{array}$ & $\begin{array}{l}1.949 \\
2.186\end{array}$ & $1 / 8$ & $\begin{array}{l}\text { FALL } \\
\text { SPRIIIG }\end{array}$ & $\begin{array}{l}31.94 \\
27.14\end{array}$ & $\begin{array}{l}6.84 ? \\
1.403\end{array}$ \\
\hline $1 / 12$ & $\begin{array}{l}\text { FALL } \\
\text { SPRJIG }\end{array}$ & $\begin{array}{l}43.28 \\
42.72\end{array}$ & $\begin{array}{l}4.095 \\
4.583\end{array}$ & $1 / 9$ & $\begin{array}{l}\text { FALL } \\
\text { SPRING }\end{array}$ & $\begin{array}{l}51.12 \\
54.74\end{array}$ & $\begin{array}{l}2.171 \\
2.314\end{array}$ \\
\hline $1 / 13$ & $\begin{array}{l}\text { FALL } \\
\text { SPRIYIG }\end{array}$ & $\begin{array}{l}31.94 \\
35.12\end{array}$ & $\begin{array}{l}4.308 \\
4.218\end{array}$ & $1 / 10$ & $\begin{array}{l}\text { FALL } \\
\text { SFRIHG }\end{array}$ & $\begin{array}{l}51.78 \\
58.76\end{array}$ & $\begin{array}{l}1.868 \\
2.639\end{array}$ \\
\hline $1 / 20$ & $\begin{array}{l}\text { FALL } \\
\text { SFRIIIG }\end{array}$ & $\begin{array}{l}43.42 \\
44.02\end{array}$ & $\begin{array}{l}7.804 \\
6.686\end{array}$ & $1 / 11$ & $\begin{array}{l}\text { FALL } \\
\text { SPRING }\end{array}$ & $\begin{array}{l}39.00 \\
36.20\end{array}$ & $\begin{array}{l}1.298 \\
2.029\end{array}$ \\
\hline $2 / 3$ & $\begin{array}{l}\text { FALL } \\
\text { SFRIIYG }\end{array}$ & $\begin{array}{l}\angle E .20 \\
51.70\end{array}$ & $\begin{array}{l}2.479 \\
1.567\end{array}$ & $2>7$ & $\begin{array}{l}\text { FALL } \\
\text { SPRIIIG }\end{array}$ & $\begin{array}{l}48.08 \\
53.02\end{array}$ & $\begin{array}{l}2.783 \\
1.714\end{array}$ \\
\hline $4 / 9$ & $\begin{array}{l}\text { FALL } \\
\text { SFRING }\end{array}$ & $\begin{array}{l}45.12 \\
36.74\end{array}$ & $\begin{array}{l}3.245 \\
1.792\end{array}$ & 5,50 & $\begin{array}{l}\text { FALL } \\
\text { SPRIIIJ }\end{array}$ & $\begin{array}{l}52.76 \\
49.26\end{array}$ & $\begin{array}{l}2.374 \\
1.757\end{array}$ \\
\hline 5.7 & $\begin{array}{l}\text { FFiLL } \\
\text { SFRIIIG }\end{array}$ & $\begin{array}{l}52.78 \\
43.02\end{array}$ & $\begin{array}{l}2.32 ? \\
7.11 .7\end{array}$ & $3 / 1$ & $\begin{array}{l}\text { FALL } \\
\text { SPRING }\end{array}$ & $\begin{array}{l}36.52 \\
47.06\end{array}$ & $\begin{array}{l}3.038 \\
0.865\end{array}$ \\
\hline $5 / 8$ & $\begin{array}{l}\text { FALL } \\
\text { SPRING }\end{array}$ & $\begin{array}{l}55.12 \\
57.22\end{array}$ & $\begin{array}{l}1.56 \% \\
5.87 \%\end{array}$ & $3 / 5$ & $\begin{array}{l}\text { FALL } \\
\text { SWPING }\end{array}$ & $\begin{array}{l}39.34 \\
5.7 .14\end{array}$ & $\begin{array}{l}3.842 \\
0.716\end{array}$ \\
\hline $5 / 10$ & $\begin{array}{l}\text { FALL } \\
\text { SFRIMG }\end{array}$ & $\begin{array}{l}55.84 \\
=3.26\end{array}$ & $\begin{array}{l}3.501 \\
1.122\end{array}$ & $3 / 3$ & $\begin{array}{l}\text { FALL } \\
\text { SPRING }\end{array}$ & $\begin{array}{l}49.60 \\
45.18\end{array}$ & $\begin{array}{l}1.111 \\
1.303\end{array}$ \\
\hline 5,11 & $\begin{array}{l}\text { FALL } \\
\text { JFRING }\end{array}$ & $\begin{array}{l}50.44 \\
4.0 .08\end{array}$ & $\begin{array}{l}\text { ᄅ. } 237 \\
0.396\end{array}$ & $4 / 10$ & $\begin{array}{l}\text { FAL!. } \\
\text { SPRING }\end{array}$ & $\begin{array}{l}<8.28 \\
30.69\end{array}$ & $\begin{array}{l}3.858 \\
3.240\end{array}$ \\
\hline \multirow[t]{5}{*}{$5 / 14$} & $\begin{array}{l}\text { FALL } \\
\text { SFRIIIIS }\end{array}$ & $\begin{array}{l}\angle 5.58 \\
45.22\end{array}$ & $\begin{array}{l}1.901 \\
4.530\end{array}$ & $4 / 12$ & $\begin{array}{l}\text { FALL } \\
\text { SPRING }\end{array}$ & $\begin{array}{l}5.5 .25 \\
51.17\end{array}$ & $\begin{array}{l}\text { J. } 909 \\
2.284\end{array}$ \\
\hline & & & & $4 \cdot 13$ & $\begin{array}{l}\text { FALL } \\
\text { SFFIING }\end{array}$ & $\begin{array}{l}46.34 \\
54.62\end{array}$ & $\begin{array}{l}1.90 .9 \\
2.224\end{array}$ \\
\hline & & & & $4 / 14$ & $\begin{array}{l}\text { FALL } \\
\text { SFRING }\end{array}$ & $\begin{array}{l}43.70 \\
\angle .19\end{array}$ & $\begin{array}{l}1.676 \\
2.017\end{array}$ \\
\hline & & & & $5: 3$ & $\begin{array}{l}\text { FALL } \\
\text { SPRIIIG }\end{array}$ & $\begin{array}{l}46.02 \\
43.53\end{array}$ & $\begin{array}{l}3.507 \\
1.753\end{array}$ \\
\hline & & & & $5 / 18$ & $\begin{array}{l}\text { FALL } \\
\text { SPRING }\end{array}$ & $\begin{array}{l}\angle 2.88 \\
\angle 7.50\end{array}$ & $\begin{array}{l}4.511 \\
3.810\end{array}$ \\
\hline
\end{tabular}


Table Fl: Continued

JRC PAUEMENTS

CRC PAUEMENTS

\begin{tabular}{|c|c|c|c|c|c|c|c|}
\hline $\begin{array}{l}\text { TEST } \\
\text { SECTION }\end{array}$ & SEASCN & $\begin{array}{l}\text { SKID N } \\
\text { NEGIY }\end{array}$ & $\begin{array}{l}\text { UMBER } \\
\text { DEU }\end{array}$ & $\begin{array}{l}\text { TEST } \\
\text { SECIIION }\end{array}$ & SEASON & $\begin{array}{l}\text { SKID I } \\
\text { MEAMY }\end{array}$ & $\begin{array}{l}\text { UMEER } \\
\text { DEU }\end{array}$ \\
\hline $1 / 6$ & $\begin{array}{l}\text { FALL } \\
\text { SPRING }\end{array}$ & $\begin{array}{l}44.46 \\
39.90\end{array}$ & $\begin{array}{l}4.028 \\
2.500\end{array}$ & $1 / 1$ & $\begin{array}{l}\text { FALL } \\
\text { SPRING }\end{array}$ & $\begin{array}{l}37.92 \\
33.52\end{array}$ & $\begin{array}{l}2.100 \\
1.254\end{array}$ \\
\hline $1 / 14$ & $\begin{array}{l}\text { FALL } \\
\text { SPRING }\end{array}$ & $\begin{array}{l}33.90 \\
43.10\end{array}$ & $\begin{array}{l}2.220 \\
1.81 .7\end{array}$ & $1 / 2$ & $\begin{array}{l}\text { FFLL } \\
\text { SPRING }\end{array}$ & $\begin{array}{l}40.14 \\
38.84\end{array}$ & $\begin{array}{l}1.293 \\
2.678\end{array}$ \\
\hline $1 / 15$ & $\begin{array}{l}\text { FALL } \\
\text { SPRING }\end{array}$ & $\begin{array}{l}41.44 \\
43.38\end{array}$ & $\begin{array}{l}3.244 \\
3.640\end{array}$ & $2 / 8$ & $\begin{array}{l}\text { FALL } \\
\text { SPRING }\end{array}$ & $\begin{array}{l}40.66 \\
41.60\end{array}$ & $\begin{array}{l}1.851 \\
2.430\end{array}$ \\
\hline $1 / 16$ & $\begin{array}{l}\text { FALL } \\
\text { SPRIUG }\end{array}$ & $\begin{array}{l}44.44 \\
39.86\end{array}$ & $\begin{array}{l}5.607 \\
2.22 .4\end{array}$ & $2 / 10$ & $\begin{array}{l}\text { FALL } \\
\text { SPRIHG }\end{array}$ & $\begin{array}{r}37.92 \\
33.96\end{array}$ & $\begin{array}{l}4.288 \\
0.929\end{array}$ \\
\hline 1,17 & $\begin{array}{l}\text { FiA'L } \\
\text { SPRING }\end{array}$ & $\begin{array}{l}43.36 \\
42.34\end{array}$ & $\begin{array}{l}1.588 \\
3.172\end{array}$ & $2 / 11$ & $\begin{array}{l}\text { FALL } \\
\text { SPRING }\end{array}$ & 33.74 & 0.921 \\
\hline $4 / 3$ & $\begin{array}{l}\text { FALL } \\
\text { SPRIING }\end{array}$ & $\begin{array}{l}53.84 \\
58.06\end{array}$ & $\begin{array}{l}2.08 ? \\
2.093\end{array}$ & & & & \\
\hline $4 / 4$ & $\begin{array}{l}\text { FALL } \\
\text { SPRING }\end{array}$ & $\begin{array}{l}50.14 \\
53.25\end{array}$ & $\begin{array}{l}2.486 \\
2.203\end{array}$ & & & & \\
\hline $4 / 6$ & $\begin{array}{l}\text { FALL } \\
\text { SPFE INE }\end{array}$ & $\begin{array}{l}35.60 \\
37.80\end{array}$ & $\begin{array}{l}2.41 \% \\
1.49 i 3\end{array}$ & & & & \\
\hline $4 / 11$ & $\begin{array}{l}\text { FALL } \\
\text { SPRING }\end{array}$ & $\begin{array}{l}45.56 \\
50.45\end{array}$ & $\begin{array}{l}4.58 ? \\
2.25 ?\end{array}$ & & & & \\
\hline $5 / 19$ & $\begin{array}{l}\text { FALL } \\
\text { SPRTING }\end{array}$ & $\begin{array}{r}55.94 \\
33.91\end{array}$ & $\begin{array}{l}0.776 \\
3.8115\end{array}$ & & & & \\
\hline $5 / 20$ & $\begin{array}{l}\text { FPLLL } \\
\text { SPRIHE }\end{array}$ & $\begin{array}{l}3.74 \\
27.50\end{array}$ & $\begin{array}{l}1.75 !] \\
2.999\end{array}$ & & & & \\
\hline
\end{tabular}



